UNIVERSIDADE DE SÃO PAULO

FACULDADE DE FILOSOFIA, LETRAS E CIÊNCIAS HUMANAS

DEPARTAMENTO DE LETRAS MODERNAS

PROGRAMA DE PÓS-GRADUAÇÃO EM ESTUDOS LINGUÍSTICOS,

LITERÁRIOS E TRADUTOLÓGICOS EM FRANCÊS

PAULA SOUZA DIAS NOGUEIRA

\title{
Espinhos da tradução: uma leitura de Mémoires de porc-épic, de Alain Mabanckou
}

v. 1

versão corrigida

São Paulo 


\section{Espinhos da tradução: uma leitura de Mémoires de porc-épic, de Alain Mabanckou}

Paula Souza Dias Nogueira

Dissertação apresentada ao Programa de pós-graduação em Estudos Linguísticos, Literários $\mathrm{e}$

Tradutológicos em Francês do Departamento de Letras Modernas da Faculdade de Filosofia, Letras e Ciências Humanas da Universidade de São Paulo, para a obtenção do título de Mestre em Letras.

Orientador: Prof. Dr. Álvaro Silveira Faleiros

v.1

versão corrigida

São Paulo 
Autorizo a reprodução e divulgação total ou parcial deste trabalho, por qualquer meio convencional ou eletrônico, para fins de estudo e pesquisa, desde que citada a fonte.

Catalogação na Publicação

Serviço de Biblioteca e Documentação

Faculdade de Filosofia, Letras e Ciências Humanas da Universidade de São Paulo

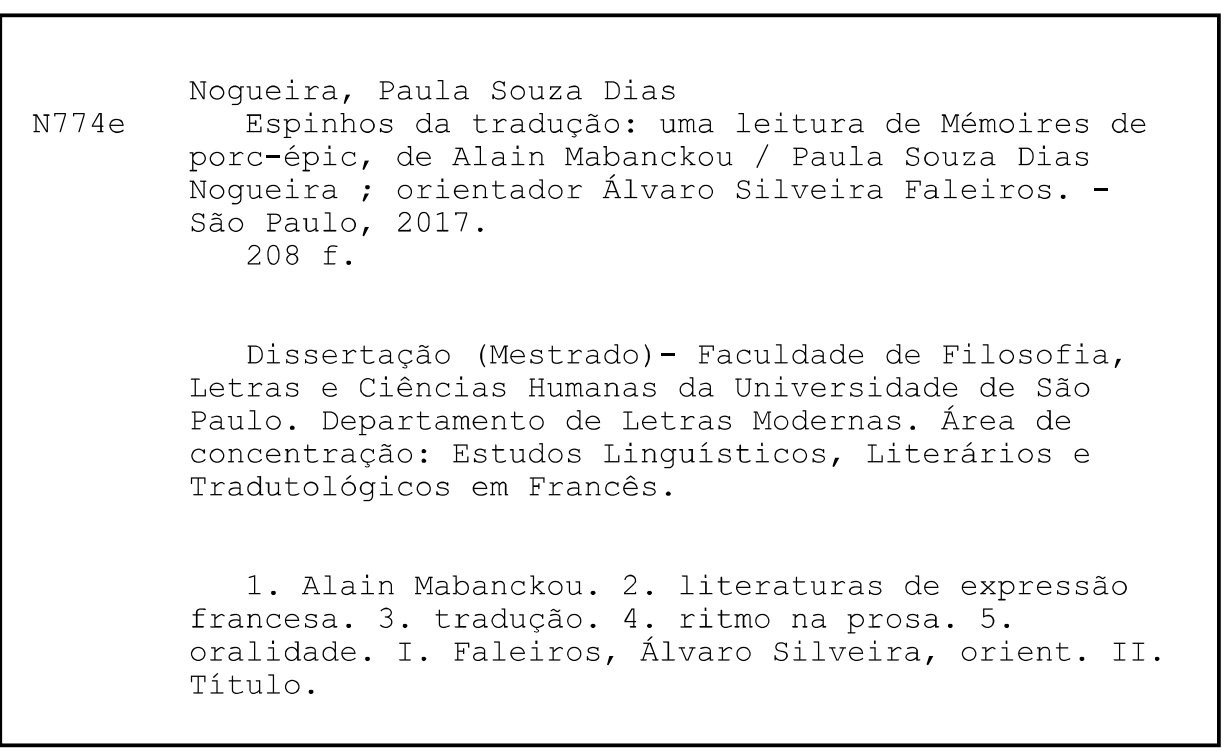


Nome: NOGUEIRA, Paula Souza Dias

Título: Espinhos da tradução: uma leitura de Mémoires de porc-épic, de Alain Mabanckou

Dissertação apresentada ao Departamento de Letras Modernas, Programa de Estudos Linguísticos, Literários e Tradutológicos em Francês da Universidade de São Paulo para obtenção do título de Mestre em Letras.

Aprovada em:

Banca Examinadora

Prof. Dr. Instituição:

Julgamento: Assinatura:

Prof. Dr. Instituição:

Julgamento: Assinatura:

Prof. Dr. Instituição:

Julgamento: Assinatura: 
NOGUEIRA, P. S. D. Espinhos da tradução: uma leitura de Mémoires de porc-épic, de Alain Mabanckou. 2017. 208 f. Dissertação (Mestrado) - Faculdade de Filosofia, Letras e Ciências Humanas, Universidade de São Paulo, São Paulo, 2017.

\section{ERRATA}

Na página 5, de agradecimentos, parágrafo 3, linhas 6, 7 e 8, onde se lê “À Fundação de Amparo à Pesquisa do Estado de São Paulo (FAPESP) pela concessão da bolsa de mestrado e pelo apoio financeiro, essencial para a realização desta pesquisa" deve-se ler: "À Fundação de Amparo à Pesquisa do Estado de São Paulo (FAPESP) pela concessão da bolsa de mestrado (processo número 2014/22068-9) e pelo apoio financeiro, essencial para a realização desta pesquisa".

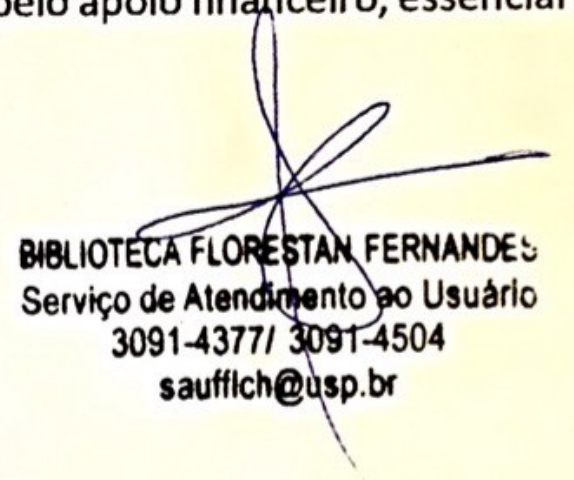




\section{AGRADECIMENTOS}

Em primeiro lugar, ao meu orientador Prof. Dr. Álvaro Faleiros pela disponibilidade e presença ao longo deste processo, e também por suas leituras minuciosas e comentários pertinentes e fundamentais para a realização deste trabalho.

À Prof. Dra. Adriana Zavaglia pela ajuda em relação aos fraseologismos e pelos comentários todos.

À Fundação de Amparo à Pesquisa do Estado de São Paulo (FAPESP) pela concessão da bolsa de mestrado e pelo apoio financeiro, essencial para a realização desta pesquisa.

Aos meus pais, Marco Aurélio e Péia, e meu irmão, Caio, pelo apoio, incentivo e afeto, sempre. Ao meu pai, Marco, em especial, pela leitura atenta, pela prontidão e pelas ótimas sugestões e correções ao texto. 


\section{RESUMO}

NOGUEIRA, P. S. D. Espinhos da tradução: uma leitura de Mémoires de porc-épic, de Alain Mabanckou. 2017. 208 f. Dissertação (Mestrado) - Faculdade de Filosofia, Letras e Ciências Humanas, Universidade de São Paulo, São Paulo, 2017.

O objetivo deste trabalho é apresentar ao leitor brasileiro a tradução do romance Mémoires de porc-épic (2006), de Alain Mabanckou. Para chegarmos à tradução, fez-se necessário entender alguns elementos centrais de sua poética e da estrutura narrativa do romance, assim como sua trajetória de vida e obra. Para tanto, discorremos, num primeiro momento, sobre sua visão de mundo e sobre as principais dimensões de sua poética, relacionando-os, sobretudo, ao pensamento rizomático proposto por Édouard Glissant. Em seguida, analisamos o romance em questão atentando para elementos macroestruturais, relacionados à literatura oral tradicional de algumas sociedades africanas de expressão francesa, nos baseando, majoritariamente, nos estudos feitos por Jacques Chevrier, e em elementos microestruturais, concernentes ao uso de repetições, paralelismos, interjeições, léxico africano, provérbios, responsáveis por criar o que Mabanckou chama de "ritmo congolês" da narrativa. Por fim, destinamos o terceiro capítulo à discussão tradutória, no qual apresentamos nosso projeto de tradução, baseado na abordagem de viés não etnocêntrico proposta, entre outros, por Antoine Berman; e nossa concepção sobre as notas de tradução, levando em consideração, primordialmente, o pensamento de Ana Cristina Cesar em relação ao ritmo na prosa. Apresentamos as notas de tradução divididas em dois blocos, o semântico e o sintático, ambos em diálogo com o que entendemos ser o ritmo da narrativa. A tradução completa é vista no anexo.

Palavras-chave: Alain Mabanckou; literaturas de expressão francesa; literatura-mundo em francês; literatura de tradição oral; oralidade; ritmo da prosa; tradução. 


\begin{abstract}
NOGUEIRA, P. S. D. Thorns of translation: a reading of Mémoires de porc-épic, by Alain Mabanckou. 2017. 208 f. Dissertação (Mestrado) - Faculdade de Filosofia, Letras e Ciências Humanas, Universidade de São Paulo, São Paulo, 2017.
\end{abstract}

The aim of this work is to present to the Brazilian public the translation of Mémoires de porc-épic (2006), a novel by Alain Mabanckou. In order to arrive at the translation, it seemed necessary to have a more in-depth understanding of some of the central elements of the poetic and narrative structure of the novel, as well as the author's life and work. Therefore, we at first discuss his worldview and the main dimensions of his poetics; relating them, especially, to the concept of rhizome proposed by philosopher Édouard Glissant. Then, we analyze the novel in question, with attention to the macrostructural elements related to traditional oral literature in some African societies of French expression, drawing mainly on studies by Jacques Chevrier, as well as microstructural elements concerning the use of repetitions, parallelisms, interjections, African vocabulary and proverbs, responsible for creating the "Congolese rhythm" of the narrative. Finally, the third chapter discusses the translation and presents the translation project, drawing upon the non-ethnocentric approach proposed, among others, by Antoine Berman, and our conception of the translation notes, taking into account primarily the thoughts of Ana Cristina Cesar regarding rhythm in prose. The translation notes are divided into two blocks, semantic and syntactic, which are both in dialogue with what we understand to be the rhythm of the narrative. The full translation is located in the Annex.

Key-words: Alain Mabanckou; French speaking literature; french world literature; traditional oral literature; orality; rhythm in prose; translation. 


\section{Sumário}

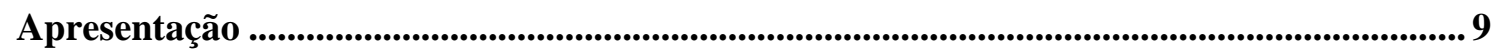

Capítulo 1 - Mabanckou, uma poética em movimento ………………….......................................... 12

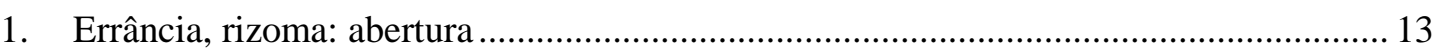

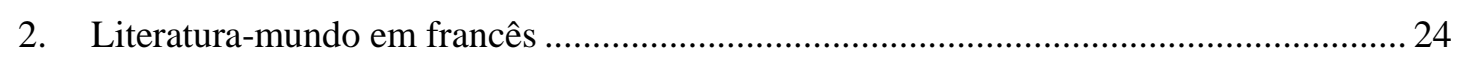

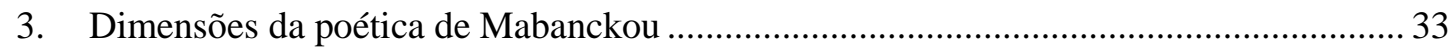

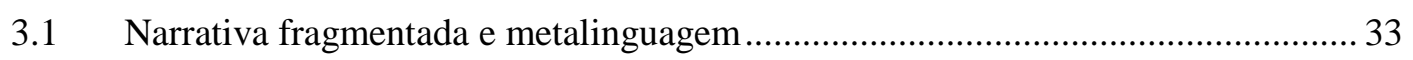

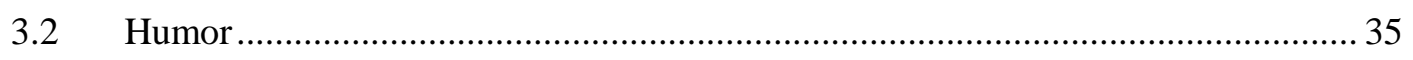

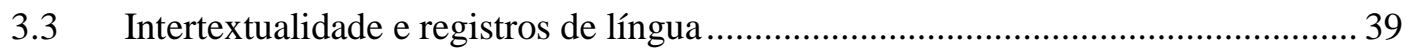

3.4 Temática: identidade e imigração ............................................................................ 43

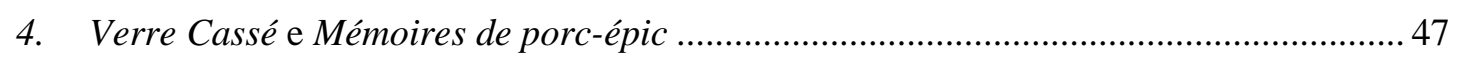

Capítulo 2 - Mémoires de porc-épic: a oralidade e seus desdobramentos na escrita ........... 52

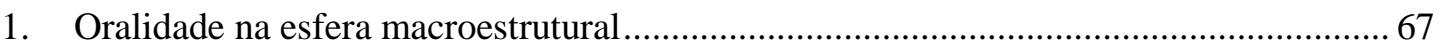

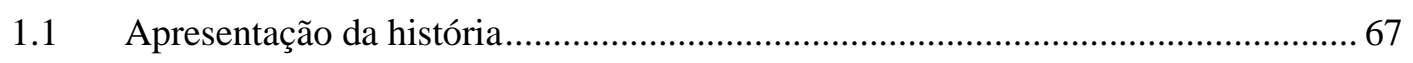

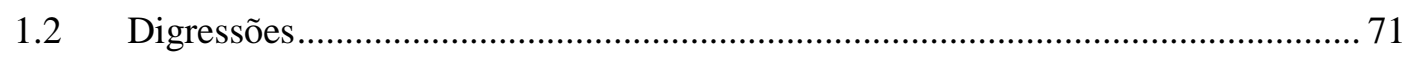

1.3 Intertextualidade: provérbios e alusões literárias.................................................. 73

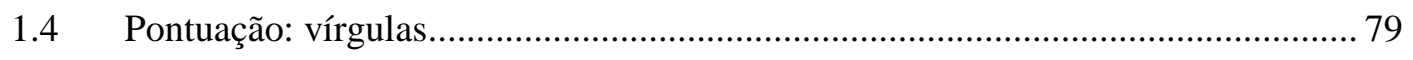

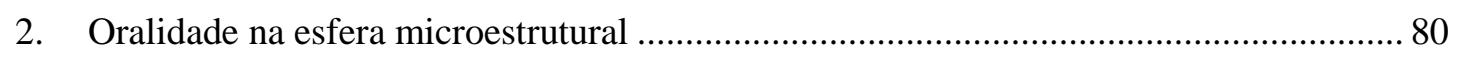

Capítulo 3 - Espinhos da tradução........................................................................................................... 87

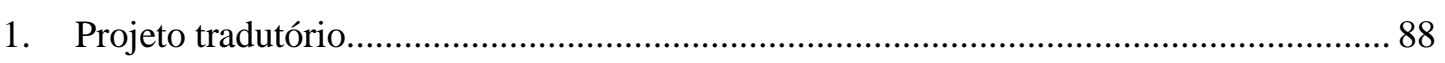

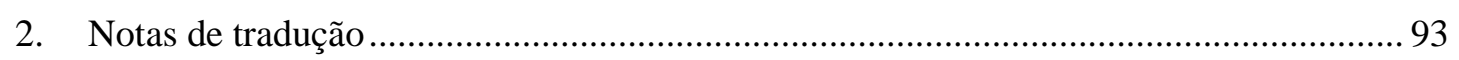

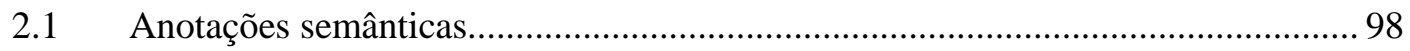

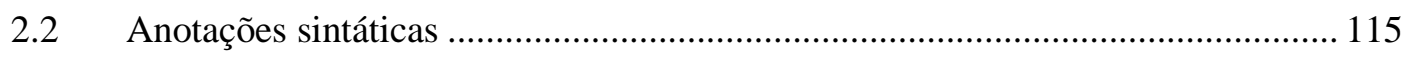

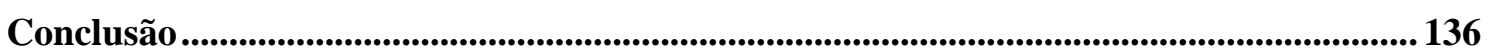

Referências bibliográficas................................................................................................................... 140

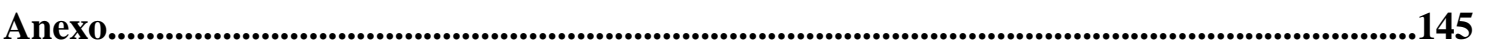

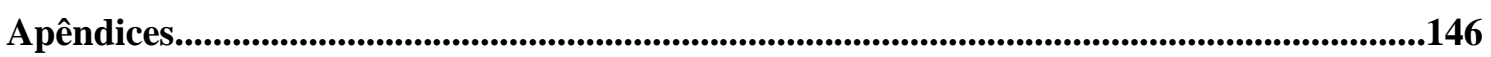




\section{Apresentação}

O caminho que me levou até a obra de Alain Mabanckou foi inusitado. A primeira vez que ouvi seu nome estava de intercâmbio na França, mas não dei muita importância. Anos depois, morando nos Estados Unidos, relembrei não sei bem como dele e fui atrás de seus livros. Apaixonei-me por sua escrita descontraída, irônica e divertida. Encantei-me pelas referências congolesas e pela aproximação com a África, que se relaciona muito mais à nossa própria história, no Brasil, do que a França. Gosto de pensar que esse caminho errante que me levou até os romances de Mabanckou dialoga com sua própria história e sua maneira de ver as relações humanas. Ao começar a leitura de seus livros, tive a ideia da tradução para o português e, com ela, o desejo de transformar isso em um estudo mais consistente sobre o autor e sua poética.

Inicialmente pensava que o estudo sobre o Congo seria indispensável, mas à medida que fui me aprofundando em sua obra ficou claro que o que estava em jogo não era caracterizar o autor como pertencente a esta ou àquela literatura ou país, mas sim entendê-lo em movimento entre diferentes culturas e países. A disciplina "Para uma Geopoética das Línguas e Literaturas. Uma Leitura dos Ensaios de Édouard Glissant”, ministrada pela Prof. Véronique Dahlet, foi fundamental nesse sentido, pois pude ter contato com o pensamento de Édouard Glissant e com a discussão sobre identidaderizoma, definida por ele a partir do estudo de Deleuze e Guattari. Com efeito, a leitura de Glissant se mostrou primordial para pensarmos não apenas sobre a visão de mundo de Mabanckou, mas também sobre como apresentá-lo ao leitor da dissertação de forma não categórica e excludente.

Logo, a relação entre o pensamento rizomático de Glissant e a trajetória pessoal e intelectual de Alain Mabanckou é esmiuçada no Capítulo 1, no qual estão presentes também considerações sobre a literatura-mundo em francês e as principais dimensões da poética do autor. Vale ressaltar que a discussão sobre o "Manifesto por uma LiteraturaMundo em Francês" gerou grande polêmica no momento de sua publicação e posteriormente, porém, pelo fato de o tema deste trabalho ser a tradução, não desenvolvi uma análise crítica sobre o assunto. Detive-me em apresentar o manifesto e as reivindicações ali propostas, bem como a posição de Mabanckou em relação a ele. 
O Capítulo 2, trata, de fato, do romance objeto deste estudo, Mémoires de porcépic, publicado em 2006 na França. Tendo sido traduzido para mais de 15 línguas (português de Portugal — esgotada e inacessível —, hebraico, coreano, polonês, sueco, para citar algumas), é curioso Mabanckou ainda ser desconhecido do público brasileiro. Ele é atualmente um dos escritores de expressão francesa mais conhecidos na Europa e notadamente na França, tendo sido eleito este ano professor convidado do Collège de France e o primeiro escritor a ocupar a cadeira de criação artística na instituição. Considerando sua importância no cenário literário europeu contemporâneo, a escolha de traduzir Mémoires de porc-épic, ganhador do prêmio Renaudot, entre outros, parece relevante para a cena editorial brasileira e, no âmbito acadêmico, onde o autor é ainda pouco prestigiado, importante para inaugurar, quem sabe, novas perspectivas de estudo na área das literaturas de expressão francesa.

O intuito deste trabalho, portanto, é o de apresentar o autor no Brasil e divulgar sua obra, que acredito poder proporcionar, entre outras coisas, reflexões sobre as relações identitárias entre potências e colônias, bem como sobre nossa própria relação, no Brasil, com a África e suas influências. Ao longo do estudo sobre o romance, o que mais saltou aos olhos foi, sem dúvida, o diálogo que há com a tradição oral de contação de histórias, típica em vários países africanos, incluindo a República do Congo. Assim, no Capítulo 2 há um estudo, baseado principalmente nas pesquisas de Jacques Chevrier, sobre a literatura oral tradicional africana e, em seguida, sobre seus desdobramentos na escrita do livro. Destacam-se elementos concernentes ao que denominei de esfera macro e microestrutural do romance, ambas em relação direta com o ritmo das contações de histórias recriado por Mabanckou.

Para poder, por fim, falar sobre tradução, foi fundamental entender o que o próprio Mabanckou denomina como "ritmo congolês" e, consequentemente, o estudo sobre a literatura oral ganhou força. Da mesma maneira, o capítulo inicial sobre o pensamento rizomático permitiu-me perceber a movência do autor entre diferentes culturas e sua relação com o Outro, o que influenciou minha reflexão sobre o processo tradutório, uma vez que a tradução pode ser compreendida como um trabalho em relação com a alteridade.

Enfim, o Capítulo 3 se destina a apresentar o projeto tradutório escolhido para o romance, tendo como base teórica, sobretudo, as pesquisas de Antoine Berman e 
Schleiermacher sobre a abordagem de viés não etnocêntrico. A escolha por esse tipo de abordagem se deu, fundamentalmente, com o intuito de recriar o ritmo instaurado por Mabanckou. Ainda nesse último capítulo, discuto a importância e o lugar que as notas de tradução recebem e explico como o trabalho é organizado. Para tanto, me baseio nos estudos de Mittmann e, principalmente, em Ana Cristina Cesar, não só no que concerne às notas, mas também no que diz respeito ao que ela chama de "ritmo da prosa".

Por último, mas não menos importante, apresento as anotações de tradução em dois blocos, o semântico e o sintático, acompanhadas de dúvidas e questionamentos que, acredito, mostram um pouco das inquietações - espinhos - com que deparei ao longo da tradução. 


\section{Capítulo 1}

\section{Mabanckou, uma poética em movimento}

je n'ai pour attaches

que la somme des intersections

les échos de Babel

Alain Mabanckou

Tant que les arbres s'enracineront dans la terre, Paris, ed. Points, 2007,

p.244 
A República do Congo é o lugar do cordão umbilical, a França, a pátria de adoção de meus sonhos, e a América, esse canto afastado a partir do qual eu olho as pegadas de minha errância. Não se trata mais de escolher entre tal ou tal terra, se trata para mim de me sentir livre, de navegar entre as fronteiras. (MABANCKOU, 2011, p.117)

Mais do que definir e enquadrar Alain Mabanckou dentro de uma nomenclatura pré-estabelecida, a ideia deste primeiro capítulo é compor um panorama de sua vida e obra a partir do entendimento de seu movimento pelo mundo. Como se pode notar na citação acima, o próprio autor se vê navegando entre as fronteiras, criando e recriando sua visão de mundo e sua identidade ao longo do caminho, no contato com diferentes países e línguas. O sentimento de liberdade exposto por ele vai ao encontro da ideia de abertura ao Outro, sem preconceitos ou barreiras, o que pode remeter ao conceito de rizoma de Deleuze e Guattari, retrabalhado também por Glissant. Desenvolveremos esse conceito num primeiro momento, atentando para as intersecções que podemos observar entre a trajetória de Mabanckou e o pensamento rizomático e, num segundo momento, discutiremos a literatura-mundo em francês e a posição do autor em relação a ela. Por fim, procuraremos apresentar algumas das dimensões temáticas e estilísticas mais presentes na obra de Mabanckou, sempre pensando em articular os debates sobre rizoma e literatura-mundo a esses elementos de sua poética.

\section{Errância, rizoma: abertura}

Alain Mabanckou nasceu em 1966 na República do Congo. No entanto, sua trajetória de vida e obra nos faz embarcar em um universo plural, no qual as fronteiras entre os países em que viveu são moventes, híbridas, assim como sua relação com as diferentes culturas com que teve e tem contato. Sua postura em relação à identidade e à literatura de expressão francesa está intrinsecamente ligada à noção de abertura ao Outro, e isso pode ser percebido também na maneira como articula o processo de criação narrativa de seus romances.

\footnotetext{
${ }^{1}$ No original: "Le Congo est le lieu du cordon ombilical, la France, la patrie d'adoption de mês rêves, et l'Amérique, ce coin éloigné depuis lequel je regarde les empreintes de mon errance. Il ne s'agit plus de choisir entre telle ou telle terre, il s'agit pour moi de me sentir libre, de naviguer entre les frontières".

${ }^{2}$ Todas as traduções apresentadas aqui são minhas, salvo casos em que o nome do tradutor é indicado.
} 
Assim sendo, achamos interessante nos voltarmos ao pensamento de Édouard Glissant, baseado nos estudos feitos por Gilles Deleuze e Félix Guattari em Mille Plateaux - capitalisme et schizophrénie, publicado em 1980, acerca do conceito de rizoma e, consequentemente, de identidade-rizoma, a fim de nos aproximarmos da visão de mundo e da obra de Mabanckou. É importante salientar a origem do pensamento rizomático nesse momento para, então, entendermos a leitura que Édouard Glissant faz do conceito.

No capítulo introdutório de Mil Platôs (publicado em português pela Editora 34 em 1995), Deleuze e Guattari discorrem, num primeiro momento, sobre a composição da própria natureza, que não segue necessariamente a lógica binária do um que se transforma em dois, podendo passar do um ao três, sem perder, no entanto, uma unidade de base principal. Diferente da raiz única, os sistemas que compõem a natureza são pivotantes, têm múltiplas ramificações, englobam a ideia de multiplicidade. Deleuze e Guattari os chamam de rizomas. Escrevem eles (1995, p.13-14): ${ }^{3}$

É preciso fazer o múltiplo, não acrescentando sempre uma dimensão superior, mas, ao contrário, de maneira simples, com força de sobriedade, no nível das dimensões de que se dispõe, sempre n-1 (é somente assim que o uno faz parte do múltiplo, estando sempre subtraído dele). Subtrair o único da multiplicidade a ser constituída: escrever a n-1. Um tal sistema poderia ser chamado de rizoma. Um rizoma como haste subterrânea distingue-se absolutamente das raizes e radículas. Os bulbos, os tubérculos são rizomas.

Os autores se baseiam no sistema do rizoma tal qual aparece na natureza para falar, na verdade, do rizoma aplicado a muitos aspectos da modernidade. Enumeram algumas características centrais desse sistema, que são, resumidamente: 1) e 2) "Princípios de conexão e de heterogeneidade: qualquer ponto de um rizoma pode ser conectado a qualquer outro" (Ibid., p.14). Aplicam essa ideia à língua, que não é fechada em si, é heterogênea; 3) Princípio da multiplicidade: a multiplicidade não é fixa, ela muda conforme aumentam ou diminuem as conexões; 4) Princípio da ruptura asignificante: o rizoma pode ser rompido em qualquer ponto e ser retomado a partir de outra linha já existente, ou de uma nova linha; 5) e 6) Princípio de cartografia e de decalcomania: um rizoma é como um mapa, não segue a lógica do decalque e da reprodução, própria da árvore, é aberto e pode ser montado e remontado.

\footnotetext{
${ }^{3}$ Tradução de Aurelio Guerra Neto e Celia Pinto Costa.
} 
A partir desses princípios básicos, Deleuze e Guattari mostram como o sistema do rizoma é movente e múltiplo, ou seja, se modifica e se reestrutura de acordo com as conexões que faz, que podem surgir e morrer em qualquer momento e em qualquer ponto do rizoma, de forma aleatória. Oposto à árvore de raiz única, que suga e mata tudo ao seu redor, o rizoma se estende na terra e no ar de forma horizontal, mantendo o enraizamento não de forma totalitária, hierárquica, mas sim sem centro e periferia, sem dominador e dominado. Assim, pode ser entendido como metáfora para pensarmos conceitos e ideias como a língua, a literatura, a identidade, as relações entre os países. Os filósofos franceses acreditam que as relações entre as pessoas e os povos seguem esse padrão rizomático, ou seja, não são previamente orientadas e formuladas, mas se dão a partir do contato com o Outro, imprevisível, espontâneo, sem necessariamente uma imposição do dominante ao dominado.

Isso posto, é possível entender quando Édouard Glissant, filósofo e poeta martiniquense, aprofunda a discussão explicando que "o pensamento do rizoma estaria no princípio do que eu chamo de poética da Relação, segundo a qual toda identidade se estende em uma relação com o Outro" (GLISSANT, 1990, p.23). ${ }^{4}$ Ao dizer isso, o autor questiona o processo colonizador, que se formou ao redor da ideia de poder totalitário, assimilacionista, como uma raiz única, e não como um rizoma, se relacionando com suas colônias. Mabanckou, discutindo a imigração, também reflete sobre as mesmas questões ao dizer que os partidários da uniformidade do país, ainda presos a essa ideia colonialista de assimilação, veem a identidade como um direito de sangue e de solo, ou, seguindo o pensamento de Glissant, como uma raiz, imutável e adquirida no nascimento. Para esses partidários, a multiplicidade vinda com os imigrantes seria um fator a ameaçar a identidade da nação, não sendo vista como uma possibilidade de troca e influência positiva.

Glissant, levando em conta a história das Antilhas, elabora sua poética da Relação ao pensar na importância da relação entre o Mesmo, que teria sido imposto pelo Ocidente no processo de colonização das Antilhas, e o Diverso, que vem dos povos submetidos aos poderes dos colonizadores. Para o filósofo, a relação do Mesmo com o Diverso seria, também, rizomática, pois não busca a exclusão de um ou de outro: "O Diverso, que não é o caótico nem o estéril, significa o esforço do espírito humano em

\footnotetext{
${ }^{4}$ No original: "La pensée du rhizome serait au principe de ce que j'appelle une poétique de la Relation, selon laquelle toute identité s'étend dans un rapport à l'Autre".
} 
direção a uma relação transversal, sem transcendência universalista. O Diverso precisa da presença dos povos, não mais como objeto a sublimar, mas como objeto a colocar em relação" (1981, p.190). ${ }^{5}$

Nesse sentido, uma identidade rizomática abarcaria não somente aqueles nascidos em território francês, aos quais a nacionalidade foi dada pelo sangue, mas também aqueles que escolheram e lutaram por ela, de forma que o chamado "povo francês" englobasse, também, o Diverso. Analogamente, Glissant elabora o que ele chama de "pensamento arquipélico" (GLISSANT, 2009, p.45), próprio às ilhas como as que formam as Antilhas, banhadas pelo mar do Caribe, que se abrem para o oceano Atlântico, possibilitando encontros e trocas imprevisíveis. Ao contrário do mar Mediterrâneo, que é cercado por terras, as ilhas do arquipélago caribenho estão dispostas de forma a possibilitar novas relações. Oposto a isso teríamos o "pensamento continental" (Idem), próprio a uma nação colonialista e fechada em si mesma, que seria como a raiz.

A partir dessa analogia, Glissant desenvolve sua poética da Relação e o conceito de "identidade-rizoma" (2010, p.40), que seria uma identidade que engloba a diversidade, sem esquecer-se de seu enraizamento, "uma identidade-raiz que não mata ao redor dela, mas que, ao contrário, estende seus galhos em direção aos outros" (Idem). ${ }^{6}$

Ainda que Glissant tenha como base para o seu pensamento a história das Antilhas, é possível fazer um paralelo de sua teoria ao pensarmos, também, em outros povos colonizados, ponderando suas diferenças, que sempre existirão. No caso de Mabanckou, temos a República do Congo, país da África central, que também foi colonizado pela França. O país é igualmente conhecido por Congo-Brazzaville, distinguindo-se da República Democrática do Congo, ou Congo-Kinshasa. Sua densidade demográfica é fraca, 13 hab. $/ \mathrm{km}^{2}$, estando a maior parte concentrada nas duas principais cidades, Brazzaville e Pointe-Noire. Antiga colônia francesa, o país obteve a independência em 1960, após várias rebeliões e disputas internas pelo poder. O francês

\footnotetext{
${ }^{5}$ No original: "Le Divers, qui n'est pas le chaotique ni le stérile, signifie l'effort de l'esprit humain vers une relation transversale, sans transcendance universaliste. Le Divers a besoin de la présence des peuples, non plus comme objet à sublimer, mais comme objet à mettre en relation".

${ }^{6}$ No original: "une identité-racine qui ne tue pas autor d'elle mais qui au contraire étend ses branches vers les autres".
} 
é a língua oficial do país, que conta também com outras línguas nacionais bantu, ${ }^{7}$ por exemplo o lingala e o kikongo. Não é raro, portanto, que seus habitantes saibam o francês, língua oficial, mas também línguas locais, familiares. Poderíamos assim pensar na ideia da língua francesa representando o Mesmo do qual fala Glissant, uma vez que foi a língua imposta de fora, e das línguas autóctones representando o Diverso.

No caso de Alain Mabanckou, ele se considera falante de quatro línguas africanas, segundo atesta em entrevista a Jeune Afrique: "O que me diferencia de meus colegas franceses é que eu pratico quatro outras línguas, sem contar agora o inglês: o lingala, o munukutuba, o laari e o bembê. Compreendo também várias outras línguas da África central". 8 Adquire o gosto pela leitura ainda criança, quando se fascina pelo mundo das histórias em quadrinho. $\mathrm{O}$ autor, nascido em uma pequena cidade próxima a Mouyondzi, no sul da República do Congo, diz que lia escondido em uma pequena biblioteca, pois seu pai, Roger Kimangou, recepcionista de hotel, desaprovava a prática, dizendo que a leitura poluía a inocência de uma criança. Filho único, Mabanckou logo percebe que, com os romances, é possível descobrir novos mundos e personagens. Assim, desde cedo, a leitura e a escrita entram em sua vida e o cativam completamente. ${ }^{9}$

Em 1972 muda-se para Pointe-Noire, onde permanece por 12 anos. Lá, estuda letras e filosofia no colégio, mas acaba se desviando da área para satisfazer o desejo de sua mãe, Pauline Kengué, comerciante (NDOMBI-SOW, 2012, p.140), que, sem saber ler nem escrever, gostaria que ele se tornasse advogado. ${ }^{10}$ Então, em 1986, começa o curso de Direito na Universidade Marien-Ngouabi em Brazzaville, capital do país, onde vive por dois anos. Durante esse período Mabanckou começa a escrever poesia e a descobrir autores que acabam por influenciar sua escrita, a começar por Céline. Diz ao L'express:

\footnotetext{
7 "As línguas bantu são faladas em toda a área ao sul de uma linha aproximada desde a fronteira da Nigéria/ Camarões até o sul da Somália, e daí até a ponta da África do Sul" [Bantu languages are spoken in the whole area south of a rough line from the Nigeria/Cameroon borderland across to southern Somalia, and thence down to the tip of South Africa] (NURSE, 2008, p.2) e "algumas são línguas nacionais e oficiais, a maioria é local sem status oficial" [some are national and official languages, most are local with no official status] (Ibid., p.4).

${ }^{8}$ No original: "Ce qui me différencie de mes collègues français, c'est que je pratique quatre autres langues, sans compter maintenant l'anglais : le lingala, le munukutuba, le laari et le bembé. Je comprends par ailleurs plusieurs autres langues de l'Afrique centrale". Acessível em: < http://www.jeuneafrique.com/Article/ARTJAJA2509p022-027-bis.xml0/ >.

${ }^{9} \mathrm{O}$ autor fala sobre isso em entrevista ao L'express: < http://www.lexpress.fr/culture/livre/entretien-avecalain-mabanckou_815535.html >.

${ }^{10}$ Idem.
} 
Depois de ter descoberto Céline, bifurquei em direção aos latinoamericanos. Com eles - Gabriel García Márquez, Horacio Quiroga, Juan Rulfo... - fui extrair a veia brincalhona, o exagero e a truculência na narração. Entendi que minhas personagens deviam se parecer com aquilo que eu gostaria de ser: alguém que devora a vida e que a descreve com uma espécie de precipitação. ${ }^{11}$

O convívio do autor com diferentes línguas desde muito pequeno e, também, sua abertura e curiosidade pela literatura de outros países acabam por fazê-lo descobrir rapidamente que o mundo é plural, e isso o seduz a ponto de ele almejar transmitir, através de seus romances, a abundância de mundos aos quais teve acesso.

Em 1989, entretanto, acaba-se o período de vida congolesa. O autor obtém uma bolsa de estudos na França e muda-se para Nantes, e em seguida para Paris, para estudar na Universidade Paris-Dauphine, retornando ao país natal apenas 23 anos depois, em 2013. Na capital das luzes, continua a escrever e tenta se inserir no mercado editorial, sendo rejeitado diversas vezes. Em 1993 obtém o diploma DEA em Direito de Negócios e começa a trabalhar para o grupo Suez-Lyonnaise des Eaux, onde fica por quase uma década. No entanto, no mesmo ano de 1993, consegue publicar sua primeira coletânea de poemas, Au jour le jour, que reúne escritos da época da escola, poemas de juventude que já revelam temas que serão ao longo do tempo bastante explorados pelo autor, segundo ele próprio diz em entrevista ao Mots Pluriels em $1999 .^{12}$

Os anos parisienses terminam em 2001, quando obtém uma bolsa de residência artística nos Estados Unidos e se torna professor de literatura francófona na Universidade de Michigan. Em 2006 aceita o convite para ser professor visitante na Universidade da Califórnia em Los Angeles (UCLA), na qual é, desde 2007, professor titular. A partir de 2016 é, também, professor convidado no Collège de France, em Paris. Sua lição inaugural, intitulada "Lettres noires: des ténèbres à la lumière", foi apresentada com grande alvoroço em março deste ano.

Se Glissant defende quebrar com a ideia preconcebida da identidade como algo fixo e, por conseguinte, com a ideia de que a literatura francesa e francófona são também fixas, no sentido de que têm seu espaço delimitado, estabelecido e imutável,

\footnotetext{
${ }^{11}$ Idem. No original: "Après avoir découvert Céline, j'ai bifurqué vers les Latino-Américains. Chez eux Gabriel García Márquez, Horacio Quiroga, Juan Rulfo... - je suis allé puiser la veine cocasse, l'exagération et la truculence dans la narration. J'ai compris que mes personnages devaient ressembler à ce que j'aimerais être: quelqu'un qui croque la vie et qui la décrit avec une espèce de précipitation.”

${ }^{12}$ Acessível em: < http://motspluriels.arts.uwa.edu.au/MP1299mabanckou.html >.
} 
Mabanckou é um bom exemplo de como a literatura pode ser plural, transformando-se ao longo do próprio processo de construção a partir do contato com os outros.

Nascido no período pós-independência, Mabanckou, assim como outros escritores da mesma época, é sensível à história recente de seu país e povo, questionando as noções de língua, identidade e nação. Desde cedo em contato com diferentes línguas dentro de casa, a pluralidade cultural acaba por acompanhar o autor ao longo da vida, já que logo se muda para a França e, em seguida, para os Estados Unidos.

Sua trajetória de errância, portanto, o aproxima do pensamento rizomático de abertura ao Diverso, e o faz repensar as nomenclaturas literárias e identitárias. Mabanckou é conhecido na academia como um escritor "africain sur Seine", ou seja, africano imigrante que escreve desde a Europa, termo que já o coloca dentro de uma "caixa", de uma categoria. Definir alguém como "africano imigrante", como "francês" ou como "congolês" é algo que Mabanckou não deseja, e o atesta em seu livro autobiográfico Le sanglot de l'homme noir (2012, p.59):

[...] minha concepção de identidade ultrapassa muito as noções de território e de sangue. Cada encontro me nutre [...]. Seria inútil se limitar ao território, ignorar a multiplicação de interferências e, ademais, a complexidade dessa nova era que nos liga uns aos outros, longe das considerações geográficas. ${ }^{13}$

Mais adiante, a respeito de sua vida como imigrante e da influência desse fato em sua obra, complementa (Ibid., p.131-132):

[...] estou cada vez mais persuadido de que o deslocamento, o cruzamento das fronteiras, nutre minhas angústias, contribui para dar forma a um país imaginário que, finalmente, se parece com a minha terra de origem. É a minha própria busca interior, minha maneira de conceber o universo. Eu escolhi não me fechar, dar ouvido ao barulho e ao furor do mundo, jamais considerar as coisas de maneira fixa. Não me tornei escritor porque emigrei. Porém, adquiri outro olhar sobre a minha pátria uma vez distanciado dela. [...] A emigração contribuiu

\footnotetext{
${ }^{13}$ No original : "[...] ma conception de l'identité dépasse de très loin les notions de territoire et de sang. Chaque rencontre me nourrit [...]. Il serait vain de se cantonner au territoire, d'ignorer la multiplication des interférences et, par-delà, la complexité de cette ère nouvelle qui nous lie les uns aux autres, loin des considérations géographiques".
} 
para reforçar em mim essa inquietude que institui aos meus olhos todo processo criativo. ${ }^{14}$

Logo, mesmo se não se trata de estabelecer uma relação direta entre a trajetória de vida de Mabanckou e sua escrita, alguns aspectos de sua biografia, como a emigração, influenciaram sua maneira de ver o mundo e, assim, acabam por influenciar também sua escrita. Ele mesmo afirma que o caráter autobiográfico está presente em seus livros, ainda que misturado a elementos ficcionais:

Na maior parte de meus livros, estou presente em cada uma de minhas personagens. A parte autobiográfica reside talvez mais no destino do narrador, no qual coloco coisas que retiro à direita e à esquerda de minha própria existência. O narrador de Black Bazar é um aprendiz de escritor, é um congolês como eu, e que adora os colarinhos com três botões: eu visto sempre colarinhos com três botões! A aproximação se faz rapidamente. ${ }^{15}$

Mabanckou transmite, por intermédio de suas personagens, um pouco de sua infância congolesa e de sua vida na França e nos Estados Unidos, de forma a aproximar o público leitor de um universo pluricultural. Argumenta, em um capítulo do livro Confidences et révélations littéraires, sobre o porquê do título de seu livro Écrivain et oiseau migrateur, explicando que "o escritor se torna então essa ave migratória que se lembra de sua terra longínqua, mas consegue cantar também do galho da árvore sobre a qual está empoleirada" (SINGOU-BASSEHA, 2012, p.26). ${ }^{16}$ Ora, se nos voltarmos ao pensamento de Glissant, vemos que essa visão de Mabanckou é bastante próxima da ideia de um rizoma, ou seja, ele mantém uma base principal - sua terra longínqua mas se conecta, desconecta e reconecta com o mundo de diferentes formas, em diferentes lugares e com elementos diferentes - cantando de acordo com o galho no qual está empoleirado.

\footnotetext{
${ }^{14}$ No original : "je suis de plus en plus persuadé que le déplacement, le franchissement des frontières, nourrit mes angoisses, contribue à façonner un pays imaginaire qui, finalement, ressemble à ma terre d'origine. Il y va de ma propre quête intérieure, de ma façon de concevoir l'univers. J'ai choisi de ne pas m'enfermer, de prêter l'oreille au bruit et à la fureur du monde, de ne jamais considérer les choses de manière figée. Je ne suis pas devenu écrivain parce que j'ai émigré. En revanche, j'ai posé un autre regard sur ma patrie une fois que je m'en suis éloigné. [...] L'émigration a contribué à renforcer en moi cette inquiétude qui fonde à mes yeux toute démarche de création".

${ }^{15}$ No original: "Dans la plupart de mes livres, je suis présent dans chacun des personnages. La part d'autobiographie réside peut-être davantage dans le destin du narrateur, où je mets des choses que je puise à droite et à gauche de ma propre expérience. Le narrateur de Black Bazar est un apprenti écrivain, c'est un Congolais comme moi, et il aime les cols à trois boutons: je porte toujours des cols à trois boutons! Le rapprochement est vite fait". Acessível em: < http://www.lexpress.fr/culture/livre/entretien-avec-alainmabanckou 815535. html >.

$\frac{16}{16}$ No original: "l'écrivain devient alors cet oiseau migrateur qui se souvient de sa terre loitaine, mais entreprend aussi de chanter depuis la branche de l'arbre sur laquelle il est perché".
} 
Assim, ainda que muitas vezes ambientando suas narrativas fora do Congo, há sempre um desejo e uma tentativa de integrar elementos do mundo exterior ao mundo interior de um congolês. Nas palavras do autor, "não escapamos de nossas origens ou então nos tornamos um pequeno papagaio que é prisioneiro de um sistema. Eu falo do Congo desde os primeiros livros, mesmo quando olho para a Europa, o Congo está sempre presente" (PHILIPPE (org.), 2013, p.182). ${ }^{17}$

No início de sua carreira, quando ainda conciliava o trabalho de advogado com a escrita, publica majoritariamente poesia. Em 1998 publica seu primeiro romance, BleuBlanc-Rouge, que ganha o Grand Prix Littéraire de l'Afrique Noire, consagrando-o como escritor. Nesse livro, Mabanckou entra na temática da diáspora africana dos anos 1990, contando a tragédia da imigração e o conflito identitário de um jovem imigrante em Paris. Em entrevista (SINGOU-BASSEHA, 2012, p.16), esclarece que a obtenção desse primeiro prêmio o encorajou a continuar seu caminho nas letras, além de trazer orgulho a seu país natal.

A partir desse momento, Mabanckou passa a publicar periodicamente tanto em prosa quanto em poesia, mas é sobretudo com seus romances que fica conhecido do grande público, notadamente com Verre Cassé (2005), ganhador do Prix des Cinq Continents de la Francophonie, Prix Ouest-France/Étonnants Voyageurs e Prix RFO du Livre, e Mémoires de porc-épic (2006), que recebe o Prix Renaudot, o Prix Aliénor d'Aquitaine, o Prix de la Rentrée Littéraire Française e o Prix Créateurs Sans Frontières. Até então, seus livros haviam sido publicados pela editora Présence Africaine e Le Serpent à Plumes, mas com a saída de seu editor desta última, Mabanckou tenta a sorte sozinho. Envia o manuscrito de Verre Cassé para a editora Minuit e para a Seuil, mas apenas esta última o aceita. O livro acaba por marcar não somente a mudança do autor para as Éditions du Seuil, mas também uma mudança em seu estilo de escrita. Segundo o autor:

Verre Cassé representa também uma reviravolta em minha maneira de escrever. Eu mudo de registro, tomo licenças na escrita. O escrevi na solidão dos Estados Unidos e da África. É, aliás, o livro ao qual os leitores me remetem sempre. Quatro anos após sua publicação ele

\footnotetext{
${ }^{17}$ No original: "On n'échappe pas à ses origines ou bien on devient un petit perroquet qui est prisonnier d'un système. Moi je parle du Congo depuis les premiers livres, même quand je regarde l'Europe, le Congo est toujours présent".
} 
continua vendendo bem. Foi adaptado para o teatro. Recebeu muitos prêmios literários. Foi traduzido para uma dúzia de línguas. ${ }^{18}$

A mudança de registro da qual fala Mabanckou diz respeito ao jogo linguístico que ele faz em seus livros, notadamente em Verre Cassé e Mémoires de porc-épic, como veremos detalhadamente adiante. Neles, o autor brinca com os limites entre a língua escrita e a oralidade e, assim, acaba por questionar a norma padrão, a língua imposta e a visão unitária do mundo. A oposição tradição/ modernidade, ou oralidade/ escrita, é muito presente nas sociedades africanas, onde as línguas locais geralmente não são ensinadas nas escolas, permanecendo orais, sendo a língua escrita a do colonizador. Ao inserir em sua escrita em francês palavras, expressões ou ritmos congoleses, Mabanckou se aproxima mais uma vez da ideia de rizoma, no sentido de que não deseja contrapor a escrita com elementos orais, mas antes mesclar elementos dos dois registros, criando o seu próprio registro que englobaria sem dúvida aspectos congoleses, mas também franceses, americanos, espanhóis, e assim por diante. Na verdade, para além do registro, o autor brinca com diferentes poéticas, a francesa e a congolesa principalmente, sem, no entanto, hierarquizá-las, mas sim as colocando em relação.

Segundo Glissant, a problemática linguística é mais comum para escritores que, como Mabanckou, convivem com várias línguas, uma imposta pela colonização e a(s) outra(s) falada(s) em família. Normalmente essas línguas autóctones sofrem influência da língua oficial, imposta, além de serem frágeis, muitas vezes orais, portanto difíceis de transcrever. Conforme diz Damato em seus estudos sobre Glissant, para o filósofo a tarefa do escritor seria a de "dar dignidade à língua popular, à língua oral permitindo que ela irrigue o escrito" (1995, p.269), porém sem hierarquização, fazendo confluir o oral e o escrito.

Ao dizer que o escritor tem a tarefa de apropriar-se da língua e dar dignidade à língua oral, Glissant refere-se ao que ele denomina "imaginário das línguas", quer dizer, à abertura do escritor a todas as línguas do mundo e suas interferências: "Hoje, mesmo quando um escritor não conhece nenhuma outra língua, ele leva em consideração,

\footnotetext{
${ }^{18}$ No original: "Verre Cassé représente également un tournant dans ma façon d'écrire. Je change de registre, je prends des licences dans l'écriture. Je l'ai écrit dans la solitude des Etats-Unis et de l'Afrique. C'est d'ailleurs le livre vers lequel les lecteurs me ramènent toujours. Quatre ans après sa parution, il continue à bien se vendre. Il a été adapté au théâtre. Il a reçu beaucoup de prix littéraires. Il a été traduit dans une douzaine de langues". Acessível em: < http://www.lexpress.fr/culture/livre/entretien-avec-alain-

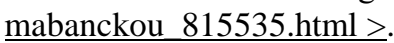


sabendo ou não, a existência dessas línguas ao redor dele em seu processo de escrita" (GLISSANT, 2010, p.14). ${ }^{19}$ Para o filósofo, esse imaginário das línguas chega até nós pela televisão, pelo rádio, pela internet, pelo cinema, de maneira que as imagens e os sons que vemos e escutamos nos colocam em relação com outras línguas e culturas. Escrever de maneira monolíngue seria como basear-se na imagem da árvore-raiz, enquanto escrever na presença de todas as línguas se aproximaria da imagem do rizoma. Tal visão, acreditamos, é partilhada por Mabanckou quando coloca elementos próprios da poética congolesa em sua narrativa, assim como quando insere referências e interferências de outras poéticas em suas histórias, como veremos adiante.

A partir de 2001, quando se muda para os Estados Unidos, Mabanckou passa definitivamente a ter como prioridade profissional a escrita e o ensino de literatura, abandonando a carreira na advocacia. No ano de 2009 publica outro romance que fica entre as 20 melhores vendas na França, Black Bazar. Em 2010 temos Demain j'aurai vingt ans, que recebe o Prix Georges Brassens e em 2013 Lumières de Pointe-Noire, romance que nasce do seu retorno ao Congo. ${ }^{20}$

Em 2012 o autor é coroado com o Grand Prix de littérature Henri Gal pelo conjunto de sua obra e em 2013 com o Prix Prince-Pierre-de-Monaco, também pelo conjunto da obra. Em 2015 foi um dos finalistas do Man Booker International Prize, ao lado de escritores consagrados, por exemplo o moçambicano Mia Couto.

Acompanhando os diversos prêmios literários que ganhou, a mídia também participa fortemente da difusão de sua obra. Cada livro lançado é um acontecimento para os jornalistas e críticos, que logo apresentam ao público resenhas, artigos e entrevistas em diversos jornais e revistas, sendo o autor um dos mais aclamados pela crítica literária francesa (NDOMBI-SOW, 2012, p.157). A inserção e a notoriedade no sistema literário francês, no entanto, não impediu Mabanckou de se questionar sobre sua própria posição e de abrir o debate ao público. O ápice da discussão ocorre em 2006, ano em que vários dos prêmios literários franceses são consagrados a escritores ditos francófonos, vindos de fora da França. Nesse momento, alguns desses escritores percebem esse movimento não como mero acaso, mas sim como o começo de uma nova

\footnotetext{
19 No original: “Aujourd'hui, même quand un écrivain ne connaît aucune autre langue, il tient compte, qu'il le sache ou non, de l'existance de ces langues autour de lui dans son processus d'écriture".

${ }_{20}$ Para ver a lista completa de obras do autor, consultar: < http://www.college-defrance.fr/media/presse/UPL181793705361781418_DP_A_Mabanckou.pdf $>$.
} 
visão sobre a chamada "literatura francófona". Assim, firma-se em 2007 o "Manifesto por uma Literatura-Mundo em Francês", assinados por 44 escritores, ${ }^{21}$ incluindo Alain Mabanckou e Édouard Glissant. ${ }^{22}$

\title{
2. Literatura-mundo em francês
}

Para entendermos o surgimento do manifesto, é necessário contextualizar, ainda que brevemente, a literatura de expressão francesa ao longo do século XX e no início do XXI.

Ofuscado pela poesia, predominante até 1950 com o movimento da negritude, o romance africano de expressão francesa começa a ganhar espaço no cenário literário nesse período, quando o sistema colonial passa a ser contestado. Segundo Chevrier (1999, p.37):

\begin{abstract}
Essa entrada brusca dos romancistas na cena literária africana relega para o segundo plano a produção poética — que não se torna menos importante - e traduz sem dúvida uma evolução dos espíritos no momento em que se acelera o processo de descolonização iniciado logo após a Segunda Guerra Mundial, e que levará rapidamente às independências dos anos $1960 .^{23}$
\end{abstract}

Nesse momento a produção é, sobretudo, de romances realistas, que procuram retratar a vida colonial, denunciando o sistema opressor e sendo um meio de resistência a ele. Também nessa época surgem os romances históricos, que buscam resgatar valores tradicionais e mostrar o enraizamento histórico e cultural dos povos, o que leva ao

\footnotetext{
${ }^{21}$ Muriel Barbery, Tahar Ben Jelloun, Alain Borer, Roland Brival, Maryse Condé, Didier Daeninckx, Ananda Devi, Alain Dugrand, Edouard Glissant, Jacques Godbout, Nancy Huston, Koffi Kwahulé, Dany Laferrière, Gilles Lapouge, Jean-Marie Laclavetine, Michel Layaz, Michel Le Bris, JMG Le Clézio, Yvon Le Men, Amin Maalouf, Alain Mabanckou, Anna Moï, Wajdi Mouawad, Nimrod, Wilfried N'Sondé, Esther Orner, Erik Orsenna, Benoît Peeters, Patrick Rambaud, Gisèle Pineau, Jean-Claude Pirotte, Grégoire Polet, Patrick Raynal, Jean-Luc V. Raharimanana, Jean Rouaud, Boualem Sansal, Dai Sitje, Brina Svit, Lyonel Trouillot, Anne Vallaeys, Jean Vautrin, André Velter, Gary Victor, Abdourahman A. Waberi.

${ }^{22}$ A discussão, na verdade, já havia sido iniciada, ainda que sob outro enfoque, na década de 1990, quando Glissant começa a falar em "chaos-monde" e "tout-monde", termos que dialogam claramente com "littérature-monde". Não iremos, no entanto, nos aprofundar nesta relação.

${ }^{23}$ No original: "Cette entrée en force des romanciers sur la scène littéraire africaine relègue au second plan la production poétique - qui n'en demeure pas moins importante - et elle traduit sans doute une évolution des esprits au moment où s'accélère le processus de décolonisation amorcé au lendemain de la Seconde Guerre Mondiale, et qui aboutira bientôt aux indépendances des années 1960”.
} 
registro de narrativas orais, contos e lendas. No fim dessa década os romances passam a ser ambientados nas cidades, não mais nas aldeias, e surge assim o romance de formação, no qual a personagem central é muitas vezes um trabalhador imigrante ou um estudante que vai às grandes cidades para ter acesso à cultura "universal", que seria vista como superior à cultura colonizada. Um exemplo seria o romance L'enfant noir, de Camara Laye (1953). O herói desse período tem esperança e sonha com um futuro melhor, de independência e liberdade.

A partir de 1960, porém, começa o processo de independência de vários países africanos, e isso afeta a produção literária do período. Apesar de continuarem retratando a vida na cidade e suas violências, os romances dessa geração passam a mostrar as infâmias e a impostura do sistema pós-colonial, além de se questionarem sobre a relação do homem com a concepção tradicional do mundo. O sentimento de esperança visto anteriormente cede lugar ao desencanto que chega junto com a descolonização. Um dos romances mais famosos desse período é Les soleils des indépendances, de Amadou Kourouma (1968).

Com a independência das colônias, os romances passam a refletir a nova sociedade que se forma e as dificuldades em adaptar-se a ela. Emerge assim uma nova temática central: a imigração e suas consequências. Uma vez que muitos dos autores da segunda geração pós-colonial passaram por processos de imigração, seja enquanto crianças, seja já na vida adulta, as personagens de seus romances — de forte caráter autobiográfico — refletem essas trajetórias e questionam-se a respeito da identidade, como é o caso de Mabanckou. Essas personagens sentem-se desenraizadas, não pertencendo nem à cultura de origem nem à cultura de adoção, e partem em busca de suas identidades perdidas, o que as leva a indagar sobre o próprio uso da língua francesa como meio de comunicação. Como bem observa Chevrier (1999, p.102):

Houve então uma dupla ruptura na cadeia de comunicação, e essa circunstância não é sem consequência para a evolução de uma literatura, certamente escrita em francês, mas em um contexto de diglossia em que esse idioma tornou-se com o passar dos anos língua plural, permeável às línguas vernaculares assim como às realidades estrangeiras que elas veiculam. ${ }^{24}$

\footnotetext{
${ }^{24}$ No original: "Il y a donc eu double rupture dans la chaîne de communication, et cette circonstance n'est pas sans conséquence sur l'évolution d'une littérature, certes écrite en français, mais dans un contexte de
} 
No plano linguístico, o questionamento ao francês como língua de escrita aparece na linguagem próxima à oralidade, nos empréstimos lexicais e sintáticos vindos de línguas africanas, na desconstrução de normas fonéticas, lexicais e até mesmo gramaticais. Em Mabanckou, é clara a influência das várias línguas africanas às quais foi exposto ao longo da vida em seus romances, conforme iremos aprofundar posteriormente. Essas estratégias narrativas remetem os autores do período à tradição oral, porém não é possível dizer que essa literatura é um prolongamento da oralidade, assim como os autores também não querem ser encaixados numa ramificação da literatura francesa. A especificidade dos textos do período é justamente seu caráter múltiplo, que leva em conta simultaneamente a tradição oral, as influências autóctones e as influências ocidentais e extraocidentais.

No plano da narrativa, as personagens imigrantes marcam a marginalidade com que são vistas pela sociedade, além de acentuarem a crítica aos modelos, formas e temas impostos pelo imperialismo. Quando não imigrantes, elas mantêm, entretanto, o caráter marginal, questionador da norma. Nas palavras de Carmen Husti-Laboye (2010, p.121):

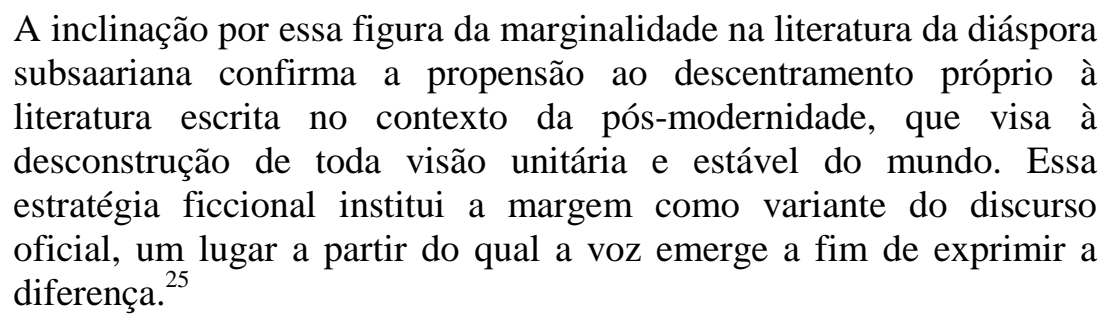

Para Mabanckou, precisamente, as personagens secundárias chamam mais sua atenção: "Penso que a verdadeira vida não é a das personagens principais. Adoro as existências conturbadas. Tenho mais coisas a dizer sobre alguém que está à margem. Sei que, por trás da marginalidade, se esconde a alegria de viver". ${ }^{26}$ Notamos, assim, em sua obra, diversos tipos marginais, tais como imigrantes (Black Bazar), intelectuais

\footnotetext{
diglossie où cet idiome est devenu au fil des années langue plurielle, perméable aux langues vernaculaires tout comme aux réalités étrangères qu'elles véhiculent".

${ }^{25}$ No original: "Le penchant pour cette figure de la marginalité dans la littérature de la diaspora subsaharienne confirme la propension au décentrement propre à la littérature écrite dans le contexte de la postmodernité, qui vise la déconstruction de toute vision unitaire et stable du monde. Cette stratégie fictionnelle institue la marge comme variante du discours officiel, un lieu à partir duquel la voix émerge afin d'exprimer la différence".

${ }^{26}$ No original: "Je pense que la vraie vie n'est pas celle des personnages principaux. J'aime les existences cabossées. J'ai plus de choses à dire sur quelqu'un qui est à la marge. Je sais que, derrière la marginalité, se cache la joie de vivre". Acessível em: < http://www.lexpress.fr/culture/livre/entretien-avec-alainmabanckou_815535.html >.
} 
excêntricos (Verre Cassé), mulheres (Les petits-fils nègres de Vercingétorix), moradores da periferia (African psycho), crianças (Demain j'aurais vingt ans) e até mesmo animais (Mémoires de porc-épic).

Vê-se, então, que enquanto a primeira geração de escritores africanos de expressão francesa buscava revelar a verdadeira identidade africana e voltava-se às questões tradicionais, a geração que surge nos anos pós-independências tende a romper com a noção de identidade como algo fixo e único, passando a enxergar esse conceito de forma híbrida, plural — enfim, rizomática. Como diz Chevrier (1999, p.74):

Entre a geração da negritude e a geração atual, as questões de fato se modificaram consideravelmente na medida em que a identidade não aparece mais hoje como um tipo de tesouro enterrado, "já aqui", que bastaria desenterrar para reintegrar o eu profundo, mas participa ao contrário de uma dinâmica na qual interferem e se justapõem fragmentos do passado e elementos da modernidade. ${ }^{27}$

Os escritores, distanciando-se tanto da origem africana quanto do acolhimento estrangeiro (francês, na maioria das vezes), partem em busca de um novo espaço identitário e literário, transpassando as barreiras territoriais até então bastante acentuadas. Nesse momento, o próprio papel do escritor de expressão francesa passa a ser contestado: até então, era esperado que ele fosse porta-voz da sociedade africana, sendo sua obra reduzida a um reflexo de sua identidade e biografia, e hoje o escritor reivindica sua liberdade criadora e estética, com obras que não necessariamente falam da África, mas sim do mundo. É assim que nasce o "Manifesto por uma LiteraturaMundo em Francês", concebido em 2006 e divulgado em março de 2007 na primeira página do jornal Le Monde, em grande alvoroço.

Sendo a discussão sobre o uso da língua francesa e sobre a identidade já dominante no discurso de muitos autores pós-coloniais, o recebimento de diversos prêmios literários em $2006^{28}$ só fez aumentar o desconforto em relação às nomenclaturas literárias e à visão imperialista, centralizada, europeia, acerca da

\footnotetext{
${ }^{27}$ No original: "Entre la génération de la négritude et la génération présente, les enjeux se sont en effet considérablement modifiés dans la mesure où l'identité n'apparaît plus aujourd'hui comme une sorte de trésor enfoui, 'déjà là', qu'il souffirait de déterrer pour réintégrer son moi profond, mais qu'elle participe au contraire d'une dynamique dans laquelle interfèrent et se télescopent fragments du passé et éléments de la modernité".

${ }^{28}$ Sabe-se, entretanto, que entre 1995 e 1998 houve um período semelhante na história literária "francófona", quando vários prêmios foram dados a escritores vindos de fora da França (PORRA, 2010, p.114).
} 
produção de expressão francesa. O que os signatários do manifesto reivindicavam ali era uma ruptura com essa visão, em que a França era o centro poderoso em torno do qual as outras nações, periféricas, orbitavam. Em outras palavras, a França seria a árvore-raiz, e as ex-colônias seriam ramificações dessa raiz, subalternas a ela, periféricas. Analogamente, a literatura-mundo almejaria ser um rizoma, relacionando-se à França horizontalmente, sem hierarquia.

Esses autores, vendo-se plurais, transnacionais, dizem escrever em francês de maneira não dominada, mas por escolha, fazendo "vibrar" a língua, como propõe Deleuze (1993). A nova nomenclatura "literatura-mundo em francês" substituiria a até então chamada "literatura francófona", que limita os escritores a um espaço determinado, sem relação com o entorno. No manifesto, lemos:

O centro, esse ponto a partir do qual uma literatura franco-francesa supostamente irradia, não é mais o centro. O centro, até agora, mesmo se cada vez menos, tinha tido essa capacidade de absorção que obrigava os autores vindos de alhures a se livrar de suas bagagens antes de se entregar ao cadinho da língua e de sua história nacional: o centro, nos dizem os prêmios do outono, está doravante em todo lugar, nos quatro cantos do mundo. Fim da francofonia. E nascimento de uma literatura-mundo em francês. ${ }^{29}$

Mabanckou já havia criticado a categoria "escritor francófono" em 2006, em artigo publicado no Le Monde, dizendo que:

Ser um escritor francófono é ser um depositário de culturas, de um turbilhão de universos. Ser um escritor francófono é, certamente, se beneficiar do legado das letras francesas, mas, sobretudo, trazer seu toque a um grande conjunto, esse toque que rompe fronteiras, apaga raças, diminui a distância dos continentes para estabelecer apenas a fraternidade pela língua e pelo universo. ${ }^{30}$

\footnotetext{
${ }^{29}$ No original : "Le centre, ce point depuis lequel était supposée rayonner une littérature franco-française, n'est plus le centre. Le centre jusqu'ici, même si de moins en moins, avait eu cette capacité d'absorption qui contraignait les auteurs venus d'ailleurs à se dépouiller de leurs bagages avant de se fondre dans le creuset de la langue et de son histoire nationale: le centre, nous disent les prix d'automne, est désormais partout, aux quatre coins du monde. Fin de la francophonie. Et naissance d'une littérature-monde en français". Acessível em : < http://www.lemonde.fr/livres/article/2007/03/15/des-ecrivains-plaident-pourun-roman-en-francais-ouvert-sur-le-monde 883572 3260.html $>$.

${ }^{30}$ No original: 'Etre un écrivain francophone, c'est être dépositaire de cultures, d'un tourbillon d'univers. Etre un écrivain francophone, c'est certes bénéficier de l'héritage des lettres françaises, mais c'est surtout apporter sa touche dans un grand ensemble, cette touche qui brise les frontières, efface les races, amoindrit la distance des continents pour ne plus établir que la fraternité par la langue et l'univers". Acessível em: < http://www.lemonde.fr/idees/article/2006/03/18/la-francophonie-oui-le-ghettonon $752169 \quad 3232 . \mathrm{html}>$.
} 
Segundo o autor, a língua francesa é o denominador comum da literatura dita francófona, é o que une todos os escritores, e não suas respectivas nacionalidades. Mabanckou acredita que as culturas se cruzam, que o mundo gira e muda, e assim a literatura em língua francesa pode adquirir um caráter universal a partir da multiplicidade de experiências de cada escritor: "A literatura-mundo é o concerto da multiplicidade de experiências, o reconhecimento da força da arte naquilo que aparece como a "desordem da vida"” (MABANCKOU, 2007, p.64). ${ }^{31}$

Se nos voltarmos para a origem do termo "francofonia", designando o conjunto daqueles que falam francês, vemos que já existe desde o fim do século XIX. Foi usado pela primeira vez em 1880 pelo geógrafo Onésime Reclus (1837-1916) em seu livro France, Algérie et colonies, no qual fala sobre o desenvolvimento do império colonial francês. Diz: "nós aceitamos como francófonos todos aqueles que são ou parecem estar destinados a continuar ou se tornar participantes de nossa língua” (RECLUS, 1880, p.422). ${ }^{32}$ Ainda que Reclus se refira ao termo para falar sobre todos aqueles que partilham a língua francesa, incluindo os departamentos além-mar, fica claro, na leitura de seu texto, que o geógrafo enxerga a língua francesa como universal, e que acredita que os valores da república deveriam se impor às culturas chamadas por ele de "bárbaras". Como diz Pinhas em seu artigo sobre a origem do discurso francófono, "a única solução que, no fim do século passado, parecia doravante possível, notadamente aos olhos de Onésime Reclus, era aquela da assimilação dos povos conquistados e da difusão da língua francesa" (PINHAS, 2004, p.74). ${ }^{33}$ Assim, a "partilha" da língua francesa era, na verdade, uma medida assimilacionista e marcava a relação de poder entre as línguas. As colônias continuariam inferiores, subalternas à metrópole, que disseminaria seus valores e sua língua, superiores, para esses povos.

O termo cai no esquecimento até meados de 1950, quando começa a se falar de francofonia cultural e política, ligada à descolonização. Fica claro, então, que o termo advém de eventos traumáticos e agressivos, e que, para além disso, é múltiplo, englobando tanto o hexágono francês quanto a Europa e os países além-mar. Em 1970,

\footnotetext{
${ }^{31}$ No original : "La littérature-monde est le concert de la multiplicité d'expériences, la reconnaissance de la force de l'art dans ce qui apparaît comme le "désordre de la vie"."

${ }^{32}$ No original: "Nous acceptons comme francophones tous ceux qui sont ou semblent destinés à rester ou à devenir participants de notre langue".

${ }^{33}$ No original: "La seule solution qui, à la fin du siècle dernier, semble désormais s'offrir, aux yeux notamment d'Onésime Reclus, est celle de l'assimilation des peuples conquis et de la difusion de la langue française".
} 
Léopold Senghor e Habib Bourguiba foram os principais pensadores que fundaram a primeira organização intergovernamental (Agence de coopération culturel et technique) para promover e difundir a língua e cultura francesa e as relações de cooperação entre seus 21 Estados-membros. Dinstingue-se, a partir daí, a Francofonia com F maiúsculo, referente à instituição, da francofonia com F minúsculo, que se refere a todos aqueles que falam francês, sendo este um termo mais neutro, usado comumente entre os linguístas e professores de línguas, em contextos limitados. Já a Francofonia, com F maiúsculo, instaurada durante o desenrolar das independências, tem conotação ideológica e política, uma vez que as ex-colônias ainda se ligam à antiga metrópole e dependem dela, tanto política quanto cultural e economicamente.

Atualmente a instituição chama-se Organização Internacional da Francofonia (OIF), é composta por 80 países-membros (sendo 23 observadores e 3 associados) e tem a missão de promover a língua francesa e a diversidade cultural e linguística; a paz, a democracia e os direitos humanos de seus países-membros; apoiar a educação, a formação, o ensino superior e a pesquisa; desenvolver a cooperação a serviço do desenvolvimento sustentável. ${ }^{34}$

A missão da OIF de promover a diversidade cultural nos países que partilham o francês é de suma importância, pois leva em conta a presença de outras línguas além do francês, porém existe a tendência de privilegiar as línguas regionais ou minoritárias endógenas em detrimento das línguas vindas do exterior da Europa, que são, no entanto, majoritariamente responsáveis pela diversidade linguística dos países europeus. Em uma conferência no Congresso Internacional de Dialetologia e Sociolinguística (Belém, 24-27 de setembro de 2012), foi apresentado um quadro com a hierarquia das línguas na Europa, e então se viu claramente que as línguas dos migrantes e/ou as línguas não europeias eram as últimas da pirâmide (CALVET, 2013, p.166), ou seja, as menos valorizadas. Em outras palavras, as medidas políticas europeias, ainda que digam levar em conta a diversidade cultural e linguística, são deveras reservadas à defesa do patrimônio, ao invés de abrir espaço para a reconstrução identitária e linguística advinda com os novos tempos.

Os signatários do manifesto de 2007, então, vistos como francófonos, sentem no dia a dia essa relação de poderes entre a França e suas ex-colônias, que se mantém até

${ }^{34}$ Dados retirados de < http://www.francophonie.org/ >. Acessado em 30/05/2016. 
hoje. E assim se perguntam: como lidar com a questão de escrever na língua imposta por seus colonizadores? Como definir o que é língua materna? Seria a língua falada em casa, pelos pais? A língua das emoções? A língua com a qual se aprendeu a escrever? Escrever em francês é ainda estar submisso aos poderes da França?

Ainda que escrevam na língua francesa, existe uma diferença - talvez não consciente - entre aqueles que escrevem francês, ou seja, para os quais o francês é a língua primeira, e aqueles que escrevem em francês, sendo a língua francesa vista, nesse caso, como estrangeira. O próprio uso do termo "escritor francófono" já transmite a conotação de que se trata de um escritor com sotaque de algum lugar, sendo o termo usado para delimitar geograficamente os escritores vindos de ex-colônias francesas. Para Mabanckou, se a França é um país-membro da Organização Internacional da Francofonia, sua população deveria ser chamada também de francófona. Ele diz: "O combate a conduzir consiste em explicar como a francofonia é uma oportunidade para todos, e não apenas um meio para que a França se assegure quanto à disseminação de sua cultura e de sua língua além-mar" (MABANCKOU, 2011, p.58). ${ }^{35}$

A noção de que a língua faz parte da cultura e é atrelada à nação e, por conseguinte, à identidade nacional, está ainda muito presente no nosso imaginário coletivo, o que muitas vezes faz com que a abertura ao Outro, aos imigrantes, por exemplo, seja rejeitada e vista como um perigo à identidade da nação. Na França, existem várias línguas regionais e dialetos que ainda são vistos como uma ameaça à língua nacional. Segundo Damato (1995, p.192):

Como bem observa Louis-Jean Calvet, a definição da nação francesa esteve sempre fortemente vinculada à ideia de unidade linguística. Essa "unidade" na realidade foi a imposição da língua de uma determinada região ao conjunto do chamado "território nacional". A marginalização das línguas regionais na França (como em outros países europeus) é ainda hoje um problema mal resolvido.

Da mesma forma que as línguas regionais ou vindas das ex-colônias não são bem incorporadas pela França, a presença de imigrantes em solo francês também não é, ainda que estes considerem o francês como língua materna. Assim, o debate sugerido pelo manifesto de 2007 nasce desse desconforto causado pela condição de inferioridade

\footnotetext{
${ }^{35}$ No original: "Le combat à mener consiste à expliquer comment la francophonie est une chance pour tous, et non seulement un moyen pour la France de se rassurer quant au rayonnement de sa culture et de sa langue au-delà des mers".
} 
ou dependência que persiste na relação entre a França e suas ex-colônias, ou seja, pela relação centro-periferia que marca profundamente a vida literária francesa.

Um ano após o manifesto, os mesmos autores publicam a coletânea Pour une littérature-monde en français, pela Gallimard, organizada por Jean Rouaud e Michel Le Bris, na qual este último discute o tema e reitera a ideia de identidade plural e abertura ao Outro (2007, p.33):

que os escritores se impusessem em uma língua de início estrangeira não era algo novo [...], mas era a primeira vez que uma geração de escritores vindos da imigração, ao invés de se apegar à sua cultura de adoção, procurava trabalhar a partir da constatação de sua identidade plural, no território ambíguo e movente desse atrito. ${ }^{36}$

Não podemos deixar de pontuar, entretanto, que o manifesto foi criticado por se mostrar contraditório e com divergências entre os próprios signatários. Alguns críticos do movimento dizem que, "longe de ser produto de uma enunciação 'descentralizada', o manifesto apenas reforça os valores do Quartier Latin, no qual eles próprios [escritores] ocupam uma posição dominante" (COMBE, 2010, p.216), ${ }^{37}$ quer dizer, existe uma contradição entre discurso e prática, uma vez que os escritores não querem ser rotulados de francófonos, mas se beneficiam do sistema literário dominante para disseminar e promover suas obras, como é o caso do próprio Mabanckou. ${ }^{38}$

Ainda assim, o manifesto serviu para trazer à tona vários problemas do sistema literário francófono e o desconforto dos autores em relação a isso. Como diz Porra em seu artigo, "reduzir essa iniciativa, como fizeram vários jornalistas e críticos desde março de 2007, a uma simples 'disputa de designações', seria fechar os olhos e negar

\footnotetext{
${ }^{36}$ No original : "que des écrivains s'imposent dans une langue au départ étrangère n'était pas chose nouvelle [...], mais c'était bien la première fois qu'une génération d'écrivains issus de l'immigration, au lieu de se couler dans sa culture d'adoption, entendait faire oeuvre à partir du constat de son identité plurielle, dans le territoire ambigu et mouvant de ce frottement".

${ }^{37}$ No original: "Loin d'être le produit d'une énonciation 'décentrée', le manifeste ne fait au contraire que conforter les valeurs du Quartier Latin, dans lequel ils occupent eux-mêmes une position dominante".

${ }^{38}$ Outras críticas relacionadas ao manifesto são esmiuçadas no artigo de Véronique Porra, "Malaise dans la littérature-monde (en français): de la reprise des discours aux paradoxes de l'énonciation", Recherches et Travaux, 76, 2010, p.108-129.
} 
problemas ligados a estruturas que muitos acadêmicos assinalam há mais de uma década" (2010, p.128). ${ }^{39}$

A seguir, tendo como pano de fundo as noções de rizoma e de literatura-mundo vistas até aqui, iremos abordar alguns aspectos relevantes da obra de Alain Mabanckou.

\section{Dimensões da poética de Mabanckou}

Partimos da consideração de que são quatro as dimensões poéticas mais relevantes no conjunto da obra de Mabanckou: 1) a narrativa fragmentada, tanto no que diz respeito a situações instáveis e híbridas quanto em relação à metalinguagem, que aparece de maneira a romper com a linearidade do relato principal; 2) o uso do humor como maneira de tratar de temas difíceis e espinhosos; 3) a intertextualidade, forma de incorporar outros autores e culturas, e a mescla de diferentes registros de língua, indo da escrita formal em francês para a linguagem popular, baixa, que remete à oralidade; 4) a temática da imigração e da identidade, responsável também por criar narrativas fragmentadas, nas quais se questionam as relações entre o eu e o Outro.

\subsection{Narrativa fragmentada e metalinguagem}

A fragmentação narrativa é uma dimensão de sua poética que dialoga muito com o que foi discutido sobre literatura-mundo anteriormente. Privilegiando estruturas híbridas, Mabanckou constrói narrativas que são poucas vezes harmônicas ou estáveis. Normalmente, as personagens se encontram em situações de errância, de questionamento, de movência. A fragmentação, no entanto, não é apenas temática: o estado mental caótico em que se encontram as personagens pode ser sentido, também, na maneira como o relato é construído.

A organização de suas narrativas segue, muitas vezes, um caminho espiral ou apenas não linear: muitos relatos começam em um momento "presente", mas remontam

\footnotetext{
${ }^{39}$ No original: "Réduire cette initiative, comme l'ont fait de nombreux journalistes et critiques depuis mars 2007, à une simple 'querelle d'appellations', reviendrait à se voiler la face et à nier des problèmes liés à des structures que de nombreux universitaires signalent depuis plus d'une décennie”.
} 
a uma história passada, para no fim voltar ao presente. Essas histórias passadas geralmente dizem respeito a outras personagens, quer dizer, a narrativa não é focada apenas na história central e num ponto de vista único, é fragmentada em outros relatos que se justapõem e em outras vozes, secundárias, que marcam o hibridismo narrativo. Essa organização da narrativa é evidenciada, principalmente, pelo uso da metalinguagem: várias vezes as próprias personagens, todas narradoras em primeira pessoa, discutem o próprio processo de escrita de seus relatos. Pensando nesses relatos, vemos que quase sempre a personagem está em vias de escrever a história que se lê, ou já escreveu um livro e o retoma ao longo da narrativa central, e essa forma de narrar, pela escrita da personagem, acaba por favorecer o uso de digressões e da estrutura não linear, pois, conforme vai se lembrando dos fatos, o narrador os conta desordenadamente. Assim, alguns exemplos seriam: em Les petits-fils nègres de Vercingétorix (2002) a protagonista conta sua história mediante o relato que escreveu em um caderno; em Black Bazar (2009), já no prólogo, o narrador conta que andam dizendo que ele está escrevendo um diário a fim de afogar suas mágoas depois de ter sido abandonado por sua mulher e filha. Encontra um amigo no bar que frequenta e este lhe questiona (MABANCKOU, 2009, p.13):

- Bem na hora, Bundólogo, você chegou, estava te esperando! Paul do Grande Congo me contou que você escreve umas coisas e que se chama Black Bazar! O que é essa farsa que você nos prepara? Por que escreve? Acha que é todo mundo que pode escrever histórias, hein $?^{40}$

Em Tais-toi et meurs (2012) o narrador-personagem escreve sua história em um caderno enquanto está na prisão: "Escrevo à mão, a lápis, que aponto às vezes com meus dentes. Quando me releio, acho que não coloquei tudo na ordem, que faltam coisas aqui e acolá" (Idem, 2012, edição kindle) ${ }^{41}$ em Verre Cassé a personagem de mesmo nome é convidada a escrever um livro sobre as histórias do bar que frequenta e, já no final de seu relato, desabafa: "e então lá se vão mais de quatro ou cinco dias que terminei a primeira parte deste caderno, sorrio após a leitura de certas páginas, elas datam de um bom tempo atrás, me pergunto no fundo se posso ficar orgulhoso disso,

\footnotetext{
${ }^{40}$ No original: “Ça tombe bien, Fessologue, tu es là, je t'attendais! Paul du Grand Congo m'a appris que tu écris des trucs et que ça s'appelle Black Bazar! C'est quoi cette arnaque que tu nous prépares? Pourquoi écris-tu? Tu crois que c'est tout le monde qui peut écrire des histoires, hein?".

${ }^{41}$ No original: "J'écris à la main, au crayon, que je taille parfois avec mes dents. Lorsque je me relis, je me dis que je n'ai pas tout remis en ordre, qu'il manque des choses ici et là".
} 
releio algumas linhas, mas sinto antes uma grande frustração" (Idem, 2005, p.113) ${ }^{42}$ e em Mémoires de porc-épic o narrador relata "oralmente" suas aventuras na savana, utilizando inúmeras digressões das quais trataremos adiante.

Nos exemplos de metalinguagem supracitados é interessante notarmos que o narrador/escritor está sempre em uma posição pouco confiante, inseguro de estar escrevendo bem e, dizendo isso ao leitor, busca sua compaixão e cumplicidade. Essas personagens frágeis - ou marginais, como vimos anteriormente — dão ao processo de escrita uma importância central, como forma de redenção e superação, já que a utilizam para livrar-se de suas mágoas, medos, tristezas. A fragmentação da narrativa acontece, portanto, nos momentos em que o narrador divaga sobre a escrita, tentando justificar-se, assim como nos momentos em que se afasta da história central para retomar algo do passado, o que também não deixa de ser uma forma de aproximar-se de seu público leitor em busca de aprovação. Ao utilizar digressões para rememorar o passado, as personagens centrais acabam por se abrir mais, contando aspectos íntimos e por vezes dolorosos de suas trajetórias, dando características sobre elas próprias e sobre outras personagens envolvidas na narrativa, indo e vindo do passado para o presente.

Se nos lembrarmos do sistema rizomático anteriormente mencionado, percebemos que esse conceito perpassa também a esfera da estrutura narrativa de Mabanckou, uma vez que as digressões não são hierarquizadas, transitam entre os tempos conforme o narrador vai se lembrando dos fatos, o que ocorre a partir de seu contato com o mundo externo (o Outro) e com a história central do livro.

\subsection{Humor}

O uso do humor para tratar de temas sérios e criticar é um recurso bastante utilizado na literatura, sendo central no caso de Mabanckou. Ele explica, em entrevista, que:

A ironia e o riso são armas temíveis que suscitam frequentemente muito mais uma reflexão do que uma abordagem rígida e séria. [...]

\footnotetext{
${ }^{42}$ No original: "et voilà donc plus de quatre ou cinq jours que j'ai terminé la première partie de ce cahier, je souris après la lecture de certaines pages, elles datent d'un bon bout de temps, je me demande au fond si je peux en être fier, je relis quelques lignes, mais je ressens plutôt une grande frustration".
} 
Prefiro encenar o papel de clown que, por trás do riso, dissimula as verdades mais revoltantes. Um provérbio africano diz: "Se você quer saber a verdade, escute os loucos" ${ }^{43}$

Por meio do riso, é possível "relativizar e transcender o trágico de uma situação" (LAJRI, 2012, p.63), acessar o não dito que está implícito naquele texto e, assim, denunciar, revelar, criticar outros discursos, estereótipos e clichês. Segundo Lajri, Mabanckou faz uso de "amplificação, exagero, justaposições insólitas [que] criam confusão e impedem toda réplica. O sarcasmo, a ironia e o humor se confundem e revelam posicionamentos múltiplos e ambíguos" (Ibid., p.67). ${ }^{44}$

Segundo o autor, o registro humorístico vem de suas origens, sendo um elemento típico da cultura congolesa: "Na África, não podemos criticar diretamente. Humilhar publicamente um primogênito ou um dignitário, isso não se faz. Mas podemos parodiar as fraquezas sociais por meio de parábolas, de fábulas" (DUCHATEL, 2007, p.11). ${ }^{45}$ Como exemplo, pensamos no trecho de Mémoires de porc-épic em que o narrador critica os homens por se vangloriarem de sua inteligência, dizendo que ele próprio, não pertencendo à raça humana, aprendeu a discernir as coisas e a pensar em boas soluções para os problemas. A passagem é irônica pois, apesar de ser um animal, o narrador é de fato bastante culto e inteligente. Para fazer sua crítica sarcástica, então, Mabanckou faz uso de uma referência ao Quarto Livro de Rabelais, e em seguida às fábulas de La Fontaine L'astrologue qui se laisse tomber dans un puits e Le corbeau voulant imiter l'aigle, dizendo (MABANCKOU, 2006, p.26):

a inteligência é uma semente que precisamos regar para ver um dia florescer, se tornar uma árvore frutífera bem enraizada, alguns ainda continuarão tão ignorantes e incultos quanto um rebanho de carneiros que se joga de um barranco porque um deles se jogou primeiro, outros ficarão idiotas assim como esse astrólogo cretino que cai no fundo de

\footnotetext{
${ }^{43}$ No original: "L'ironie et le rire sont des armes redoutables qui suscitent souvent bien plus de réflexion qu'une approche stricte et sérieuse. [...] Je préfère jouer le rôle du clown qui, derrière le rire, dissimule les vérités les plus criantes. Un proverbe africain dit : 'Si vous voulez savoir la vérité, écoutez les fous'." Acessível em: < http://evene.lefigaro.fr/livres/actualite/alain-mabanckou-black-bazar-1807.php >.

${ }^{44}$ No original: "L'amplification, l'exagération, les juxtapositions insolites [que] créent la confusion et empêchent toute réplique. Le sarcasme, l'ironie et l'humour se confondent et donnent à lire des prises de positions multiples et ambigües".

${ }^{45}$ No original: "En Afrique, on ne peut pas critiquer de front. Humilier publiquement un aîné ou un dignataire, ça ne se fait pas. Mais on peut parodier les travers sociaux à travers des paraboles, des fables".
} 
um poço ou mesmo esse corvo imitando a águia que sequestra um carneiro $^{46}$

Oana Panaïté acrescenta ainda que o sarcasmo e a ironia são também transmitidos pela estrutura sintática da narrativa, como é o caso dos romances Verre Cassé e Mémoires de porc-épic, ambos com frases sem conectores, encadeadas pelo uso da vírgula. Diz Panaïté (2012, p.222):

O encadeamento de frases não ligadas por conectores, e que descrevem, entretanto, uma progressão dramática, contribui para uma encenação cuidadosamente dosada para obter um efeito tanto patético quanto satírico. O escritor [Mabanckou] evoca em sua prosa ressonâncias ao mesmo tempo poéticas, pela repetição idêntica das mesmas fórmulas no afirmativo e no negativo, e sarcásticas. ${ }^{47}$

Em Mémoires de porc-épic, um bom exemplo de humor que é construído, também, a partir do encadeamento de frases e da repetição de estruturas é a passagem em que o narrador discorre sobre todas as suas vítimas, explicando uma a uma as razões de suas mortes. Diz assim (MABANCKOU, 2006, p.190):

nós tínhamos comido o comerciante Komayayô Batobatangá porque ele tinha se recusado a nos vender fiado um lampião e duas latas de sardinha a óleo fabricadas no Marrocos, era uma injustiça da sua parte pois todo o vilarejo comprava fiado com ele, nós tínhamos comido a velha Dikamoná porque ela fazia uns vai e vens suspeitos todas as noites diante da cabana do meu mestre $[\ldots]^{48}$

O trecho se estende ainda por uma página, mantendo o encadeamento de frases e a repetição da fórmula "nós tínhamos comido" [nous avions mangé], o que faz aumentar o possível desconforto do leitor ${ }^{49}$ em relação às razões que levaram o narrador

\footnotetext{
${ }^{46}$ No original: "l'intelligence est une graine qu'il faut arroser afin de la voir s'épanouir un jour, devenir un arbre fruitier bien enraciné, certains demeureront d'ailleurs aussi ignares et aussi incultes qu'un troupeau de moutons qui se jette dans un ravin parce que l'un d'entre eux s'y est engagé, d'autres resteront idiots tel ce crétin d'astrologue qui se laisse tomber dans un puit ou même ce malheureux corbeau imitant une aigle qui enlève un mouton".

${ }^{47}$ No original: "L'enchaînement des phrases non reliées par des connecteurs, et qui décrivent pourtant une progression dramatique, contribue à une mise en scène soigneusement dosée pour obtenir un effet tout autant pathétique que satirique. L'écrivain instille à sa prose des résonances à la fois poétiques, par la répétition à l'identique des mêmes formules à l'affirmatif et au négatif, et sarcastiques".

${ }^{48}$ No original: "Nous avions mangé l'épicier Komayayo Batobatanga parce qu'il avait réfusé de nous vendre à crédit une lampe-tempête et deux boîtes de sardines à l'huile fabriquées au Maroc, c'était une injustice de sa part car tout le vilage achetait à crédit chez lui, nous avions mangé la vieille Dikamona parce qu'elle faisait des va-et-vient suspects toutes les nuits devant la case de mon maître".

${ }^{49}$ Quando falamos em leitor, neste trabalho, estamos nos referindo a um leitor-narratário, uma entidade fictícia à qual a história é dirigida. No caso de Mémoires de porc-épic, tanto a árvore quanto um suposto público dessa contação de histórias seriam os narratários diretos do narrador porco-espinho.
} 
e seu mestre a cometer aqueles crimes. $\mathrm{O}$ humor acontece devido à naturalidade desconcertante com que o narrador justifica os assassinatos: um lampião e duas latas de sardinha foram o suficiente para enfurecer Kibandí. A banalidade dos motivos, todos bastante simples e pouco graves, provoca o riso. A cena inteira, assim, pouco verossímil, desestabiliza a ideia padrão que se tem comumente acerca do tema, o que acaba por fazer rir.

Outro exemplo em que a repetição das mesmas fórmulas no positivo e no negativo da qual fala Panaïté colabora para o efeito humorístico é o momento em que o porco-espinho discorre sobre a Bíblia e a crença cega dos aldeões na religião. Diz (Ibid., p.22):

então percorri esse livro de Deus, páginas inteiras, muito palpitantes e patéticas, lhe digo, sublinhei passagens com a ajuda dos meus espinhos, escutei com as minhas próprias pequenas orelhas muitas dessas histórias da boca de pessoas sérias, de pessoas de barbicha grisalha, de pessoas que iam aos domingos à igreja do vilarejo, elas contavam essas histórias com tal precisão e tal fé que teríamos deduzido que tinham elas mesmas sido testemunhas oculares dos fatos assim relatados ${ }^{50}$

A repetição da fórmula "de pessoas" [des gens], nesse trecho, acaba por enfatizar o argumento de que eram de fato muitas as pessoas que relatavam histórias bíblicas, porém o narrador conta isso dando a entender que ele próprio não acredita nessas histórias sem nunca ter visto deus pessoalmente, o que fica claro no final do trecho, quando fala sobre a precisão com que as pessoas contavam os fatos, como se tivessem estado lá. O humor, nesse caso, quebra com o discurso hegemônico e estereotipado acerca da religião.

Muitos dos exemplos de humor são, no caso de Mémoires de porc-épic, escatológicos. Em um dos casos, o narrador se justifica perante a árvore baobá, sua grande interlocutora, dizendo: “eu sei que você não aprecia que eu defeque no seu pé, ora os homens dizem que são os excrementos que fazem crescer os vegetais, então, de

\footnotetext{
${ }^{50}$ No original: “j'ai donc parcouru ce livre de Dieu, des pages entières, très palpitantes et pathétiques, je te dis, j'ai souligné des passages à l'aide de mes piquants, j'ai entendu de mes propres oreilles plusieurs de ces histoires de la bouche des gens sérieux, des gens à la barbichette grise, des gens qui allaient les dimanches à l'église du village, ils racontaient ces histoires avec une telle précision et une telle foi qu'on aurait déduit qu'ils avaient eux-mêmes été les témoins oculaires des faits ainsi relatés".
} 
alguma maneira, eu contribuo também para a sua longevidade, é tudo o que posso lhe oferecer em troca da sua hospitalidade" (Ibid., p.215). ${ }^{51}$

Ou então, na cena em que a mãe de Kibandí, no leito de morte, pede ao filho para que se comporte, para que não siga o mesmo caminho de seu pai, o narrador relata (Ibid., p.126):

ela relembrou a meu mestre de não desobedecê-la, de não seguir o caminho do defunto Papai Kibandí correndo o risco de acabar um dia como ele, e o jovem mestre fez a promessa, jurou três vezes em nome dos ancestrais, a mentira era grande, sem dúvida teria valido mais a pena lhe dizer a verdade pois no instante em que jurou sobre a cabeça dos antepassados um dos peidos mais sonoros que ele já tinha liberado escapou de sua bunda, eles tiveram, a moribunda e ele, de tapar as narinas, um fedor de cadáver se alastrou no cômodo a ponto de eles deixarem a porta e as janelas abertas trinta dias e trinta noites ${ }^{52}$

O humor escatológico é provocado aí pela simultaneidade das ações. A mentira é contada e imediatamente vem o peido, exageradamente alto e fedorento: é preciso deixar o recinto arejando durante trinta dias e trinta noites para que o cheiro saia.

Em resumo, o humor é sentido na obra de Mabanckou pelos elementos escatológicos; pela ironia com intuito de criticar, muitas vezes por meio de fábulas ou provérbios, o comportamento humano; pela lógica desconcertante; pelo uso da hipérbole e, também, pela construção sintática de acumulação e repetição de estruturas.

\subsection{Intertextualidade e registros de língua}

O humor e a ironia são utilizados pelo autor não somente como forma de criticar, mas também como maneira de dar voz a outros textos, discursos e autores. Tendo vivido não apenas na República do Congo, mas também na França e nos Estados

\footnotetext{
${ }^{51}$ No original: “je sais que tu n'apprécies pas que je défèque à ton pied, or les hommes disent que ce sont les excréments qui font pousser les végétaux, donc, en quelque sorte, je contribue aussi à ta longévité, c'est tout ce que je peux t'offrir en échange de ton hospitalité".

${ }^{52}$ No original: "elle rappela à mon maître de ne pas lui désobéir, de ne pas suivre le chemin du défunt Papa Kibandí au risque de finir un jour comme lui, et le jeune homme fit la promesse, jura trois fois au nom des ancêtres, le mensonge était gros, sans doute aurait-il valu mieux qu'il lui dise la vérité parce qu'à l'instant où il jura sur la tête de ses aïeux un des pets les plus sonores qu'il n'avait jamais libérés s'échappa de ses fesses, et ils durent, la mourante et lui, se boucher les narines, une puanteur de cadavre se répandit dans la pièce au point qu'ils laissèrent la porte et les fenêtres ouvertes pendant trente jours et trente nuits".
} 
Unidos, o autor faz uso de suas referências culturais variadas e as insere em seus textos, criando narrativas intertextuais e pluriculturais, remetendo à cultura congolesa mas também às outras culturas. Notadamente em Mémoires de porc-épic, assim como em Verre Cassé, esse recurso é bastante evidente: Mabanckou, a partir de suas leituras e referências, homenageia e parodia diversos autores e obras literárias. O autor diz, em entrevista, que

À medida que fui descobrindo a literatura do mundo inteiro, me dei conta de que, na verdade, a literatura em si é um grande romance. Existe na nossa bagagem de leitura bastante material para escrever. Eu me encontro no interior de todos os grandes livros do mundo. Tudo que escrevo gira em torno da relação entre o homem e o livro. E minhas piscadelas são uma maneira de homenagear esses escritores que fizeram de mim aquilo que sou. ${ }^{53}$

Em Verre Cassé, por exemplo, há um trecho que homenageia vários autores africanos (referências entre colchetes no rodapé) (Idem, 2005, p.210):

me lembrarei sempre de minha primeira travessia por um país da África, foi a Guiné, eu era o menino negro, estava fascinado pelo trabalho dos ferreiros, estava intrigado pela reptação de uma cobra mística que engolia uma cana que eu jurava estar realmente em suas mãos, e muito rápido eu voltava à terra natal, saboreava as frutas tão doces da árvore de fruta-pão, morava em um quarto do hotel La Vie et Demie, que não existe mais hoje em dia e onde cada noite, entre jazz e vinho de palma, meu pai teria exultado de alegria, e eu me aquecia ao fogo das origens ${ }^{54}$

Mas Mabanckou não se detém apenas ao continente africano, tudo é permeado pela intertextualidade: os nomes dos lugares, das personagens, os acontecimentos. Faz menção, no mesmo livro, a Gabriel García Márquez e Horacio Quiroga (Ibid., p.211), Ionesco (Ibid., p.204), às aventuras de Tintin (Ibid., p.209), assim como a muitos outros autores e a nomes da cena musical do jazz americano (Coltrane, The Monk, Davis,

\footnotetext{
${ }^{53}$ No original: “Au fur et à mesure que j'ai découvert la littérature du monde entier, je me suis rendu compte que, en réalité, la littérature elle-même est un grand roman. Il y a dans notre bagage de lecture assez de matière pour écrire. Je me retrouve à l'intérieur de tous les grands livres du monde. Tout ce que j'écris tourne donc autour du rapport entre l'homme et le livre. Et mes clins d'oeil sont une manière de rendre hommage à ces écrivains qui ont fait de moi ce que je suis". Acessível em: < http://www.lexpress.fr/culture/livre/entretien-avec-alain-mabanckou_815535.html >.

${ }^{54}$ No original: "je me souviendrai toujours de ma première traversée d'un pays d'Afrique, c'était la guinée, j'étais l'enfant noir [Camara Laye], j'étais fasciné par le labeur des forgerons, j'étais intrigué par la reptation d'un serpent mystique qui avalait un roseau que je croyais tenir réellement dans ses mains, et très vite je retournais au pays natal [Aimé Césaire], je goûtais aux fruits si doux de l'arbre à pain [Tchicaya U Tam'si], j'habitais dans une chambre de l'hôtel La Vie et Demie [Labou Tansi], qui n'existe plus de nos jours où chaque soir, entre jazz et vin de palme [Dongala], mon père aurait exulté de joie, et je me réchauffais au feu des origines [Dongala]".
} 
Bechet etc., Ibid., p.208) e do cinema (Dr. Jivago, por exemplo, Ibid., p.211). Em Mémoires de porc-épic a abundância de referências também ocorre, e trataremos delas mais detidamente no próximo capítulo. A título de exemplo, citamos aqui a menção a Le Rat de ville et le Rat des champs e L'hirondelle et les petits Oiseaux (Ibid., 2006, p.64-65), fábulas de La Fontaine.

Além das referências externas, algumas vezes o autor se refere a seus próprios livros, por exemplo em Lumières de Pointe-Noire (2013), livro autobiográfico que escreve quando retorna ao Congo, no qual faz alusão a Mémoires de porc-épic. Nele, conta sobre sua família e sua vida quando criança. Em dado momento, descobre que seu cachorro Miguel morreu por descuido de seu tio, que agora se sente culpado. O narrador o consola, dizendo que não precisa se sentir mal, e então o tio diz (Idem, 2013, p.165):

- O que você sabe sobre isso? Os animais são nossos pais, são nossos duplos, e você escreveu isso no seu livro sobre o porco-espinho...

- Eu apenas contei o que mamãe me contava. Existem também os duplos gentis, Miguel fazia parte deles, ele te perdoou por esse ato... ${ }^{55}$

Dentro dessa estética que incorpora textos e referências de outros autores na narrativa, vemos também outro tipo de intertextualidade, que diz respeito ao uso de provérbios, que muitas vezes não pertencem a um autor específico, mas sim ao imaginário de um povo. Um dos muitos exemplos que encontramos em Mémoires de porc-épic é o momento em que o narrador, voltando de uma temporada entre os humanos, discorre sobre a relação homem-animal e os preconceitos ou ideias que o velho governante incutia na cabeça dos outros porcos-espinho da comunidade. Declarada guerra e inimizade entre a espécie humana e a animal, diz: "pois bem, é preciso lhes dar o troco, é preciso levar em conta até mesmo os seus filhos que acabaram de ver o dia porque 'os filhotes do tigre não nascem sem as suas garras', assim falava nosso governante" (Idem, 2006, p.70), ${ }^{56}$ trecho no qual o provérbio aparece destacado com aspas e itálico, seguido por "assim falava nosso governante", fórmula

\footnotetext{
${ }^{55}$ No original: “- Qu'est-ce que tu en sais? Les animaux sont nos parents, ils sont nos doubles, et tu l'as écris dans ton livre sur le porc-épic... / — je n'ai fait que reporter ce que maman me racontait. Il y a aussi des doubles gentils, Miguel faisait partie d'eux, il t'a pardonné cet acte...".

${ }^{56}$ No original: "eh bien, il faut leur rendre la pareille, il faut s'en prendre même à leurs enfants qui viennent de voir le jour parce que 'les petits du tigre ne naissent pas sans leurs griffes', ainsi parlait notre gouverneur".
} 
comumente utilizada para colocar as palavras na boca de um terceiro indivíduo, dando maior crédito ao dito. Aprofundaremos esse aspecto no capítulo seguinte.

Há ainda a intertextualidade relacionada aos registros de língua, uma vez que o autor escreve respeitando as regras do francês formal, mas dá voz a personagens espontâneas, que se expressam por meio da língua informal (gírias) ou popular (linguagem familiar e escatológica), que é comumente usada em registros orais informais.

Um livro no qual o registro popular é contundente é o African Psycho (2003), romance que conta em primeira pessoa as desventuras de Grégoire, um órfão da periferia que tem o desejo de orquestrar um assassinato bem elaborado, tendo como exemplo um serial killer famoso, Angoulima. No trecho em que descreve o bairro onde se encontram as prostitutas, ele fala a respeito dessas mulheres assim (Idem, 2003, p.102):

Nenhuma estrangeira podia arrastar seus gambitos seminus nos arredores sem provocar a fúria de nossas meninas. É preciso reconhecer, para alívio dessas estrangeiras, que com as nossas meninas, o preço do passe não estava cabendo em todos os bolsos. Nossas meninas, elas têm maneiras de ser levadas a sério e de considerar sua coisa lá como a caverna de Ali Babá. Elas querem mesmo ser baratinadas, um jeito de se convencer de que elas não são putas no sentido que as pessoas entendem. ${ }^{57}$

Ao utilizar palavras como "gambito" [guibolles], "o passe" [la passe], "coisa lá" [chose-là] ou o particípio passado "baratinadas" [baratinées], Mabanckou dá leveza ao relato que, apesar de mostrar o cotidiano de um serial killer, diverte o público leitor mais uma vez vemos o humor sendo usado para tratar de temas difíceis. Trataremos mais adiante do registro informal nos livros Verre Cassé e Mémoires de porc-épic, nos quais o recurso é central.

Além disso, o autor também faz uso de léxico vindo de línguas autóctones, oriundo de seu conhecimento de 4 línguas africanas, conforme vimos no início deste

\footnotetext{
${ }^{57}$ No original: "Aucune étrangère ne pouvait trimbaler ses guibolles à moitié nues dans les parages sans subir le courroux de nos filles. Il faut reconnaître, à la décharge de ces étrangères, qu'avec nos filles, le coût de la passe n'était pas à la portée de toutes les bourses. Nos filles à nous ont des manières de se prendre au sérieux et de considérer leur chose-là comme la caverne d'Ali Baba. Elles veulent même être baratinées, histoire de se convaincre qu'elles ne sont pas des putes au sens où les gens l'entendent".
} 
capítulo. Alguns exemplos são encontrados em Mémoires de porc-épic, dos quais falaremos no próximo capítulo, mas em outros romances esse recurso também é visto.

Em Les Petits-fils nègres de Vercingétorix (2002), por exemplo, observamos termos e expressões como: os "mami watta" (p.42) que são os espíritos do rio, os "falafula" ou o "cent-cent" (p.64) que são nomes de meios de transporte, um pequeno "nganda" (p.66), que significa um pequeno bistrô, calças "pountcha” (p.72), ou seja, calças de boca larga (MANIRAMBONA, 2015, p.83).

Em todos esses casos, vemos a fusão de diferentes vozes, a mescla de registros e línguas variadas, o francês sendo predominante, porém em coexistência com outras línguas, que por sua vez não são colocadas como inferiores ou menores, mas no mesmo patamar de dignidade, importância e força. A intertextualidade se mostra, então, nessas ocasiões, relacionada ao multilinguismo das personagens, tendo o público leitor a possibilidade de acessar outras vozes textuais a partir dessa tessitura narrativa plural.

Em suma, no que se refere à intertextualidade, observamos que as alusões, paródias e homenagens que Mabanckou presta a outros autores mostram sua abertura ao Diverso: não há autor melhor ou pior, ou país com melhor ou pior literatura. O autor dá voz a diferentes escritores de forma horizontal, reflexo de sua maneira de se relacionar com a literatura. É como se, por meio das alusões literárias, o autor rompesse as fronteiras linguísticas e continentais, aproximando o público leitor de diferentes referências culturais. Sobre a mescla de registros, podemos pensar que também é um tipo de abertura ao Outro, já que a linguagem popular e familiar não é standard, formal, canônica, sendo muitas vezes relacionada ao registro oral, assim como o uso de léxico africano, uma vez que as línguas autóctones são, majoritariamente, orais. Então, ao dar voz a essas personagens plurilíngues, Mabanckou se posiciona numa esfera entre o oral e o escrito, quer dizer, numa esfera híbrida.

\subsection{Temática: identidade e imigração}

No que concerne à temática, é notável a preferência por discussões e narrativas relacionadas à imigração, identidade, processos de escrita e uso da língua francesa. Vale 
dizer que esses elementos se cruzam e se inter-relacionam, e são assim vistos em sua obra de maneira sobreposta, sendo difícil separar um do outro.

Em relação à identidade e à literatura — que se conectam ao debate sobre a literatura-mundo - , podemos pensar que a descentralização da literatura de expressão francesa está intimamente ligada à descentralização das identidades pós-modernas, ${ }^{58}$ quer dizer, é reflexo da era pós-moderna em que vivemos. Segundo Stuart Hall ${ }^{59}$ (2006), existem três diferentes concepções de identidade do sujeito. Resumidamente, são elas: a) sujeito do Iluminismo: o indivíduo é centrado, unificado, com um núcleo interior que nasce com ele e o acompanha de maneira essencialmente igual para o resto da vida; $b$ ) sujeito sociológico: o núcleo interior do sujeito não é autônomo e autossuficiente, está em constante mudança conforme as relações do sujeito com o mundo externo, o eu e a sociedade; c) sujeito pós-moderno: o núcleo interior não é mais visto como unificado e estável, mas antes fragmentado, composto de várias identidades, e a sociedade (o mundo externo) passa por mudanças estruturais, o que faz com que as identidades culturais se tornem provisórias e variáveis. Assim, a identidade do sujeito pós-moderno é "formada e transformada continuamente em relação às formas pelas quais somos representados ou interpelados nos sistemas culturais que nos rodeiam" (HALL, 2006, p.13). Hall argumenta que a pós-modernidade é caracterizada por sua descontinuidade, por uma estrutura deslocada, que "é aquela cujo centro é deslocado, não sendo substituído por outro, mas por uma 'pluralidade de centros de poder"' (Ibid., p.16).

Pensando nessa última definição de Hall, a do sujeito pós-moderno, e também no contexto social e histórico dos autores pós-coloniais, entende-se que estes "são o produto das novas diásporas criadas pelas migrações pós-coloniais. Eles devem aprender a habitar, no mínimo, duas identidades, a falar duas linguagens culturais, a traduzir e a negociar entre elas" (Ibid., p.89). Nota-se que o cenário todo aponta em direção à identidade-rizoma de Glissant: os escritores se veem inseridos em uma sociedade descontínua, possuem eles mesmos histórias de ruptura, imigração e busca identitária e acreditam em relações transversais, horizontais, nas quais as experiências vindas de fora podem mudar o rumo (ou não) da própria história. Dessa forma, defendem uma literatura que siga também esses parâmetros, quer dizer, que seja também descentralizada, horizontal, aberta ao Outro.

\footnotetext{
${ }^{58}$ Parte desta reflexão sobre a identidade faz parte de um artigo meu publicado na Revista Boitatá, "A questão da identidade em Alain Mabanckou", Boitatá, Londrina, n.17, p. 88-100, jan-jul. 2014.

${ }^{59}$ Trad. Tomaz Tadeu da Silva e Guacira Lopes Louro.
} 
Considerando isso, Mabanckou questiona a ideia de que língua, identidade e nação são algo fixo e imutável, conforme o fazem também os signatários do manifesto por uma literatura-mundo em francês. Brincando com os limites entre a língua escrita e a falada é possível, então, problematizar essas noções.

Outra forma de questionamento seria por intermédio da temática, e aí fica claro que a relação com o que vem de fora e, por consequência, a redescoberta ou a busca pela própria identidade (além da identidade literária) é um tema central na obra de Mabanckou, discutido a partir do olhar de personagens marginalizadas pelo sistema social, à beira da norma. Essas personagens repensam e discutem o discurso oficial, as formas de poder e dominação impostas pelos colonizadores, a começar da língua. Algumas vezes a discussão identitária está atrelada ao fato de as personagens serem imigrantes, como é o caso de Black Bazar ou Tais-toi et meurs, livros nos quais a discussão engloba também os preconceitos vividos por eles e a dificuldade de firmar uma identidade. Em Black Bazar, o narrador conta sobre o monsieur L'Hippocrate [senhor O hipócrita], seu vizinho preconceituoso e xenófobo (MABANCKOU, 2009, p.36):

para ele seu país é a França, e ele berra para mim seu orgulho de ser francês de origem. Eu por exemplo o escutei reclamar que a França não pode mais abrigar toda a miséria do mundo, sobretudo esses congoleses que não param de aparecer na fronteira mesmo se eles têm petróleo e madeira cortada no país deles. Existem outros países na Europa, só precisamos ir viver neles ou voltar ao nosso país para nossas cabanas de barro. E ele dizia esses absurdos me desafiando com o olhar. ${ }^{60}$

No caso de Tais-toi et meurs, o narrador-personagem imigrante é obrigado a mudar de nome e de registro por ter sido acusado injustamente de homicídio. Em consequência, fica confuso sobre sua verdadeira identidade, sentindo que a cada vez que muda os documentos perde um pouco de si e ganha um pouco do novo "eu" (Idem, 2012, edição Kindle):

Não sei mais quem, de Julien ou de José, está escrevendo estas linhas. Ousaria dizer que é José. Por outro lado José não pode existir sem

\footnotetext{
${ }^{60}$ No original: “lui son pays c'est la France, et il me gueule sa fierté d'être français de souche. Je l'ai par example entendu râler que la France ne peut plus héberger toute la misère du monde, surtout ces Congolais qui n'arrêtent pas de se pointer à la frontière alors qu'ils ont du pétrole et du bois bandé chez eux. Y a d'autres pays en Europe, on n'a qu'à aller vivre là-bas ou retourner chez nous dans nos cases en terre battue. Et il sortait ces inepties en me défiant du regard".
} 
Julien - e vice-versa. No fundo, isso mostra que ignoro doravante quem eu sou, e mais ainda quem serei amanhã. ${ }^{61}$

Em outros livros, nos quais as personagens não são imigrantes, a inquietação identitária persiste, por vezes atrelada à metalinguagem de que já falamos. Os narradores escritores se sentem inseguros em relação a sua identidade enquanto escritores, não sabem como se firmar ou se estão no caminho certo. Em Mémoires de porc-épic, ainda que a história se baseie em uma lenda sobre duplos animais, a princípio distante dos temas aqui citados, a temática da identidade e da imigração é completamente pertinente: o porco-espinho é, também, um emigrante, pois deve abandonar o seu habitat natural, junto aos outros animais, para ir viver com seu mestre na cidade. Ao mudar de ambiente, o animal tenta se adaptar à nova sociedade que lhe é imposta e reencontrar ou recriar sua própria identidade. São várias as passagens em que ele sofre por se sentir perdido, angustiado, sozinho, o que é reforçado ainda mais pelo fato de ter que assumir o papel de duplo, quer dizer, alguém com identidade duplicada. Uma vez convivendo com os homens, ele começa a incorporar atitudes e sentimentos humanos a seu modo de ser e de agir, o que lhe causa muita angústia: "tive vergonha de mim, o lado humano tomando cada vez mais conta do meu lado animal" (Idem, 2006, p.33). ${ }^{62}$ Seu destino de duplo lhe confere um alter-ego, Kibandí, seu mestre, a quem ele obedece cegamente e do qual não consegue se separar, chegando mesmo a se confundir com ele: "eu tinha a sua vida entre as minhas patas, respirava o sopro que vinha dele, eu era ele, ele era eu, e para reestabelecer as coisas eu devia me manifestar urgentemente, o meu coração iria explodir, não sabia mais quem eu era" (Ibid., p.59-60). ${ }^{63} \mathrm{O}$ movimento de errância da personagem continua mesmo após a morte de seu mestre, momento em que sê vê em sozinho no mundo, explorando o desconhecido em si e fora de si.

Enfim, dando voz aos sem voz, Mabanckou une as várias dimensões elencadas aqui em praticamente todos os seus romances. Retrata o discurso estereotipado a respeito dos imigrantes na França, assim como discute a identidade no contexto pósmoderno, no qual o "sentir-se deslocado" é bastante comum e, muitas vezes, pode ser

\footnotetext{
${ }^{61}$ No original: "Je ne sais plus qui, de Julien ou de José, est en train d'écrire ces lignes. Je serais tenté de dire que c'est José. D'un autre côté José ne peut pas exister sans Julien - et vice-versa. Au fond, cela montre que j'ignore désormais qui je suis, et plus encore qui je serai demain".

${ }^{62}$ No original : "j'ai eu honte de moi, le côté humain prenant de plus en plus le dessus sur ma nature animal".

${ }^{63}$ No original : "je tenais sa vie entre mes pattes, je respirais le souffle qui lui revenait, j'étais lui, il était moi, et pour rétablir les choses je devais me manifester en toute urgence, mon coeur allait éclater, je ne savais plus qui j'étais".
} 
extravasado pela escrita, que sabemos ser um meio de libertar-se e de criar vínculos. Seus narradores em primeira pessoa trabalham seus medos e angústias por intermédio da escrita, do humor, da ironia e, também, parodiando outros autores, por vezes justificando ou embasando seus argumentos a partir da palavra do Outro. Pode-se dizer que sua obra é, antes de tudo, um trabalho de criação literária "atípico, polissêmico e polifônico em que as palavras são notas de música que criam uma partitura leve, divertida e engraçada, evocando um contexto tragicômico" (LAJRI, 2012, p.66). ${ }^{64}$

Os dois romances mais conhecidos de Mabanckou, a saber Verre Cassé e Mémoires de porc-épic, apresentam de forma contundente as dimensões poéticas supracitadas.

\section{Verre Cassé e Mémoires de porc-épic}

Faz-se necessário comentar não apenas o livro a ser tratado nesta pesquisa, mas também o romance que o antecede, Verre Cassé [Copo quebrado], publicado em 2005. É com ambos que Mabanckou marca seu estilo literário e ganha notoriedade. O que difere esses dois romances dos outros é notadamente sua inovação gramatical e narrativa, uma vez que o único sinal de pontuação utilizado é a vírgula, além das aspas e dos itálicos para marcar os diálogos, e do uso de letras maiúsculas para nomes próprios.

Em Verre Cassé, o público leitor depara com uma verdadeira festa à literatura: o autor faz uso de diversos títulos de obras literárias — de histórias em quadrinho como Astérix e Obélix e Tintin a livros de Camara Laye, Sony Labou Tansi, Gabriel García Márquez, Salinger e até mesmo do próprio Mabanckou — para caracterizar personagens, lugares e cenas. Esse jogo de intertextualidade acaba por indicar os amores literários de Mabanckou, além de marcar o ritmo da narrativa (MALONGA, 2007). É principalmente pelo recurso da intertextualidade que o estilo do romance se faz singular, ao mesmo tempo repleto de ironias e críticas e cheio de elogios a autores e textos. Ademais, o autor tenta aproximar registros cultos, literários, de elite, a registros completamente informais, do povo, como forma de provocação à norma padrão e à

\footnotetext{
${ }^{64}$ No original : "atypique, polysémique et polyphonique où les mots sont des notes de musique que créent une partition légère, amusée et amusante, tout en evocant un contexte tragi-comique".
} 
linguagem dita literária. Ao misturar procedimentos linguísticos tais como citações diretas, paráfrases e traduções ou interpretações de outras línguas, encontramos um texto no qual ecoam outras línguas e outras culturas, e no qual as regras clássicas literárias estão em constante movimento e questionamento. Segundo Oana Panaïté, "os empréstimos e alusões literárias são tantos que uma leitura-enquente parece ser a única forma de funcionamento dessa narrativa cuja textura se caracteriza pela dosagem sutil de porosidade e opacidade, ecletismo intertextual e homogeneidade intratextual" (PANAÏTÉ, 2012, p.231). ${ }^{65}$

Assim como em muitos outros de seus romances, Verre Cassé apresenta também características autobiográficas: a personagem principal, assim como o autor, é filho único, órfão e viveu em Pointe-Noire. Na narrativa, Verre Cassé é um professor aposentado, que passa seus dias bebendo no bar Le Crédit a voyagé [O Crédito viajou] e trocando ideias com as pessoas que por ali circulam. Um dia, Escargot entêté [Escargô cabeçudo], dono do bar, que é seu amigo, lhe pede para que escreva a história do estabelecimento, e assim começa o relato.

A partir daí duas visões sobre a escrita são postas: para o dono do bar, que pediu o relato, a escrita é a única maneira de imortalizar a memória. Para Verre Cassé, o processo criativo deve ser espontâneo e livre, representando a vida cotidiana e imediata, ou seja, deve ter registro informal, próximo à fala. Deste modo, o autor coloca em discussão o próprio processo de escrita e a relação entre o escritor e sua escritura, além de referir-se à tradição oral africana e contrapô-la à visão clássica sobre a literatura, visão esta compartilhada pelo patrão do bar que, ademais, poderia representar a figura do editor de livros, muitas vezes pouco preocupado com a criatividade do texto, mas antes com a venda do livro no mercado. Mesclando as citações literárias, que fazem parte das primeiras leituras do professor aposentado, com seu relato autobiográfico em forma de confissão, Mabanckou cria uma narrativa que assimila o mundo ficcional da literatura à vida intelectual de Verre Cassé, evidenciando assim o medo da personagem de encarar a dura realidade, preferindo esconder-se sob o véu dos mundos imaginários que a literatura nos proporciona.

\footnotetext{
${ }^{65}$ No original : "Tant sont nombreux les emprunts et allusions littéraires qu'une lecture-enquête semble être le seul mode d'emploi de ce récit dont la texture se caractérise par le dosage subtil de porosité et d'opacité, d'écletisme intertextuel et d'homogénéité intratextuelle".
} 
Essa mesma personagem é também a autora das Mémoires de porc-épic, livro publicado na sequência, em 2006. O leitor, no entanto, apenas descobre a relação entre os dois livros no final do segundo, quando depara com um anexo intitulado "Carta do Escargô cabeçudo sobre a origem do manuscrito Memórias de porco-espinho" (MABANCKOU, 2006, p.223). ${ }^{66}$ Nessa carta, dirigida às edições Seuil, editora francesa que publicou o livro, o dono do bar explica que escreve em nome do já falecido Verre Cassé, autor do manuscrito. Revela, então, que o manuscrito foi encontrado no meio do mato em um estado deplorável, e que foi preciso reconstituí-lo para que pudesse ser apresentado para publicação. Assim, ele e a mais três clientes do bar se puseram a ler e a reorganizar as páginas escritas por Verre Cassé, e no fim pagaram uma estudante para datilografar o material. Conta tudo isso para justificar a razão pela qual o manuscrito não foi enviado à editora mais cedo, e também alerta que as duas últimas partes da história foram as mais comprometidas, e que por isso os editores talvez precisem consultar o original em alguns momentos.

Por fim, dá alguns detalhes sobre a história do livro, revelando que Verre Cassé agora não é mais uma personagem da história, dá a palavra a um porco-espinho, e que ele "estava persuadido de que os livros que nos seguem por muito tempo são aqueles que reinventam o mundo, revisitam nossa infância, interrogam a Origem, escrutam nossas obsessões e abalam nossas crenças" (MABANCKOU, 2006, p.228), ${ }^{67}$ pensamento que é, aliás, muitas vezes compartilhado pelo próprio Mabanckou em entrevistas a jornais e revistas. Nota-se, aqui também, o caráter autobiográfico de que falamos anteriormente, sendo a figura de Verre Cassé muito próxima à do autor.

Em Mémoires de porc-épic, cuja história será revelada no capítulo seguinte, há também a discussão sobre o processo da escrita, mas desta vez sob o ponto de vista do narrador porco-espinho, não do próprio Verre Cassé. Tanto Verre Cassé, intelectual excêntrico, quanto o porco-espinho são personagens marginais em relação aos valores disseminados pela sociedade, personagens que não se encaixam no padrão e que se recusam a aceitar a norma dominante, como vimos ser comum na obra do autor. Ao dar voz a um ser desprovido da palavra, Mabanckou elabora críticas pungentes ao Homem e ao comportamento humano, colocando o animal face ao homem, e dessa forma

\footnotetext{
${ }^{66}$ No original: "Lettre de L'escargot entêté sur l'origine du manuscrit Mémoires de porc-épic".

${ }^{67}$ No original: "il était persuadé que les livres qui nous suivent longtemps sont ceux qui réinventent le monde, revisitent notre enfance, interrogent l'Origine, scrutent nos obsessions et secouent nos croyances".
} 
remetendo à nossa própria animalidade. Usar a figura do animal para criticar é também uma maneira de, inserindo a crítica no contexto de uma fábula, trazer humor e leveza à narrativa.

Ao quebrar com o uso da língua francesa padrão e dar valor à escrita "espontânea" dessa personagem, que escreve, em ambos os livros, como se estivesse fazendo um relato oral de suas histórias, Mabanckou se aproxima da cultura oral congolesa, em um processo de transposição linguística que se mostra na composição do texto de maneira híbrida. Além disso, como vimos anteriormente, muitas de suas narrativas são fruto de lembranças e imagens de sua infância vivida no Congo, e assim percebemos vários elementos dessa cultura em sua obra. Em relação a Mémoires de porc-épic, a autora Husti-Laboye (2010, p.122) diz que,

[...] em Mémoires de porc-épic, a crença e a miríade de superstições que o acompanham no contexto africano tradicional representam os principais elementos em torno dos quais se constrói a narrativa alegórica desse narrador diretamente saído das lendas africanas. Romance construído pela fusão de dois universos distintos, Mémoires de porc-épic dá, de fato, voz a um animal ancorado na mentalidade coletiva africana, que se apresenta diante de seu interlocutor, o baobá, como o duplo maligno do homem [...]. ${ }^{68}$

Logo, a própria escolha pelo narrador animal não é aleatória, já que o porcoespinho faz parte do imaginário coletivo da África central. No livro autobiográfico Écrivain et oiseau migrateur, Mabanckou conta que existe uma lenda na África central e principalmente na República do Congo que diz que todo humano nasce com um duplo animal do qual não pode dissociar-se, de maneira que se um morre, o outro morre em seguida. Essa crença faz com que as crianças respeitem os animais e a fauna, não podendo, por exemplo, comer a carne dos bichos que são supostamente seu duplo. Cada etnia tem sua versão para essa lenda, e o autor usa notadamente a versão transmitida por sua mãe. Ele diz que sua infância foi povoada por histórias de duplos assustadores, histórias muitas vezes contadas para fazer com que as crianças voltassem para casa à

\footnotetext{
${ }^{68}$ No original: "Dans Mémoires de porc-épic, la croyance et la myriade de superstitions qui l'accompagnent dans le contexte africain traditionnel représentent les principaux éléments autour desquels se construit le récit allégorique de ce narrateur directement issu des légendes africaines. Roman construit par l'emboîtement de deux univers fictionnels distincts, Mémoires de porc-épic donne en effet la parole à un animal ancré dans la mentalité collective africaine, qui se présente devant son interlocuteur, le baobab, comme le double maléfique de l'homme".
} 
noite, com medo de cruzarem com o duplo nocivo de um feiticeiro. Em Lumières de Pointe-Noire, diz (MABANCKOU, 2013, p.173):

—É normal, o filhote deles estava contente em vê-lo, pois ele e você, vocês formam um só corpo. Essa corça e esse veado não eram animais ordinários. O macho é o duplo de seu avô Mukilá Grégoire, e a fêmea, o duplo de sua avó, Henriette N'Sokô. Se eu tivesse abatido esses bichos ao longo de nossa caçada ontem, seus avós seriam seres mortos no momento em que eu falo com você. Antes de entrar na savana devemos passar para dizer boa noite a esses duplos, são eles que nos permitem encontrar facilmente a presa. ${ }^{69}$

A inserção da narrativa no contexto congolês faz com que o leitor embarque nesse universo que integra a infância do autor mas, ao mesmo tempo, ao tratar de outros temas, aproxima-o daquilo que lhe diz respeito. Apesar de aprofundar em Mémoires de porc-épic as referências congolesas, tanto no léxico quanto na ambientação e na história, Mabanckou não deixa de fazer alusão a textos literários, passagens bíblicas, fábulas, provérbios vindos também de outros países, como uma forma de homenageálos. Em consequência, constrói uma obra ancorada no universo congolês (MALONGA, 2007, p.125), mas que dialoga com outros universos, não se fechando a uma só cultura.

No capítulo seguinte, iremos nos aprofundar na análise de Mémoires de porcépic, detalhando alguns elementos da história e observando detidamente quais características textuais compõem esse universo congolês plurilíngue do qual o autor faz parte.

\footnotetext{
${ }^{69}$ No original: "C'est normal, leur petit était content de te voir car lui et toi vous ne formez qu'un seul corps. Cette biche et ce cerf n'étaient pas des animaux ordinaires. Le mâle est le double de ton grand-père Moukila Grégoire, et la femelle, le double de ta grand-mère, Henriette N'Soko. Si j'avais abattu ces bêtes au cours de notre chasse hier, tes grands parents seraient des êtres morts au moment où je te parle. Avant d'aller dans cette brousse on doit passer dire bonsoir à ces doubles, c'est eux qui nous permettent de trouver facilement le gibier".
} 


\section{Capítulo 2}

\section{Mémoires de porc-épic: a oralidade e seus desdobramentos}

na escrita 
Em Mémoires de porc-épic (doravante mencionado como $M P E$ ), publicado em 2006 pelas Éditions du Seuil, na França, vemos Alain Mabanckou reforçar uma vez mais sua declaração de que jamais deixou de pensar a partir da cultura congolesa, e que sua escrita em francês retoma sempre esse universo. Mabanckou frisa que as línguas africanas que ele domina ecoam em seus escritos em francês e, desse modo, cria um universo ficcional plurilíngue, no qual as personagens, a situação e o ritmo na narrativa são claramente congoleses, mas a palavra é elaborada em língua francesa. Sobre a escrita em francês, diz:

Isso faz parte da minha própria cultura, já que a maior parte das línguas africanas que falo são orais. Não tendo base escrita, elas só existem por meio da oralidade. E ali vem se somar a língua francesa como língua de escrita. Finalmente, em Mémoires de porc-épic, a língua é francesa, mas o ritmo é congolês. Este é o de minha etnia, de minha tribo. Desse ritmo de dentro da língua provém toda a oralidade da narrativa. ${ }^{70}$

Para compreender o que está implicado nesse ritmo, é importante primeiramente salientar que o romance aqui estudado não apresenta a linguagem informal que ouvimos em discursos orais, pois muitas são as características que diferem um texto oral de um escrito, como a presença de um interlocutor, o planejamento, as marcas gestuais e de entonação. No entanto, dado que a literatura é também de natureza estética, o escritor tem liberdade para brincar com as variações de linguagem e criar seu próprio estilo, introduzindo elementos típicos da fala em um texto escrito, criando uma “sensação do real”. Segundo Urbano ${ }^{71}$ (apud PRETI, 2003, p.250), em Análise dos textos orais:

A língua literária é uma variante da língua escrita, mas também o é da língua popular, da língua culta, etc., no sentido de ser 'uma combinação de códigos auxiliares, superpostos ao código comum'. [...] Na verdade, sendo a obra literária de ficção uma transposição da realidade, recria no texto literário todas essas espécies ou modalidades linguísticas, porém sob o aspecto abrangente da intenção artística e estética.

\footnotetext{
${ }^{70}$ No original: "Cela fait partie de ma propre culture puisque la plupart des langues africaines que je parle sont orales. N'ayant pas de base écrite, elles n'existent qu'à travers cette oralité. Et là-dessus vient se greffer la langue française comme langue d'écriture. Finalement, dans 'Mémoires de porc-épic', la langue est française mais le rythme est congolais. C'est celui de mon ethnie, de ma tribu. De ce rythme dans la langue provient toute l'oralité du récit". Acessível em : < http://evene.lefigaro.fr/livres/actualite/alainmabanckou-renaudot-memoire-porc-epic-734.php >.

${ }^{71}$ URBANO, H. A elaboração da realidade linguística em Rubem Fonseca. São Paulo, 1985. Tese (Doutorado) - FFLCH, USP, p. 152.
} 
No caso do romance aqui estudado, essa aproximação da linguagem oral se dá mediante a inserção de elementos vindos da literatura oral das sociedades tradicionais da África de expressão francesa. Nessas sociedades, não existe uma relação de sucessão entre o oral e o escrito, são antes duas formas distintas de expressão, cada uma com suas especificidades de contexto, produção e transmissão. Dominante na África negra, a oralidade não exclui algumas formas de escrita, por exemplo, a existência de um alfabeto bamum, inventado pelo sultão Njoya, nos Camarões, entre outras (CHEVRIER, 1986, p.12). A palavra oral foi, entretanto, o que cristalizou a sabedoria africana, como diz Dadié ${ }^{72}$ (1957 apud CORNEVIN, 1976, p.40):

\begin{abstract}
A África negra, por falta de escrita, cristalizou de fato sua sabedoria na literatura oral. E cada contador, elo interrompido de um longo passado, dissemina toda noite a sabedoria dos antepassados. Ele a confia àqueles que querem tirar proveito dela e ao vento que a carregará pelo mundo, pois a sabedoria não é um bem que se conserva sozinho. ${ }^{73}$
\end{abstract}

A literatura oral é, assim, o principal suporte dessas sociedades para transmitir mitos e conhecimentos sagrados, além de criar vínculo entre as gerações passadas e presentes, de forma a dar continuidade à história desses povos. Com a introdução da escrita e o avanço na educação das camadas mais pobres das sociedades, passou-se a registrar os contos orais em coletâneas, ampliando a difusão das tradições desses povos. Posteriormente, com a colonização e a introdução do francês no cotidiano das sociedades africanas de expressão francesa, esses relatos, tanto orais quanto registrados no papel, passaram a mesclar léxico de línguas autóctones com léxico francês. Logo, vêse que, apesar de praticada desde muito antigamente, a literatura oral não se mostra engessada, mas antes se transforma ao longo do tempo. A atividade de contar oralmente uma história é espontânea e popular, manifesta-se nos mais diversos ambientes e situações, e pode ser proferida por qualquer pessoa, desde uma mãe para ninar seu filho até um sábio ancião para transmitir ensinamento aos jovens. Entretanto, ainda que relacionada à vida cotidiana dessas sociedades, a linguagem utilizada nessa atividade é muitas vezes refinada ou arcaica, diferente do falar cotidiano.

\footnotetext{
${ }^{72}$ Revue Présence Africaine, n. XIV-XV, 1957, p.165.

${ }^{73}$ No original: 'L'Afrique noire, faute d'écriture, a en effet cristallisé sa sagesse dans la littérature orale. Et chaque conteur, chaînon ininterrompu d'un long passé, essaime chaque soir la sagesse des Anciens. Il la confie à ceux qui veulent en profiter et au vent qui l'emportera par le monde car la sagesse n'est pas un bien que l'on conserve pour soi seul'.
} 
Levando isso em consideração, a linguagem dita formal utilizada por Mabanckou no romance, que num primeiro momento pode parecer distanciar-se da oralidade, está, na verdade, próxima à maneira com a qual os relatos orais acontecem. Com efeito, o romance é construído na intersecção entre a linguagem escrita, seguindo as regras gramaticais que conhecemos, e o coloquialismo próprio ao registro oral, ou seja, não nos parece cabível uma análise maniqueísta pretendendo nomear a narrativa de oral ou não, já que a percebemos em diálogo com ambas as esferas. Um caso emblemático é o uso do passé simple, por exemplo neste trecho (verbos grifados) (MABANCKOU, 2006, p.107-8):

lorsque les gaillards revinrent au village, ils furent surpris d'entendre l'annonce de la mort de Papa Kibandí, personne ne se rendit dans la case du défunt, le cadavre du vieil homme était étendu au salon, les yeux exorbités, retournés, et la langue, d'une couleur bleu ingigo, traînait jusqu'à son oreille droite, le corps se putréfiait déjà, une odeur pestilentielle s'exhalait dans les environs, et vers la fin de la journée, alors que commençaient à tomber les ténèbres, Mama Kibandi et mon jeune maître enroulèrent le cadavre dans des feuilles de palmier, le portèrent loin dans la forêt, l'enterrèrent dans un champ de bananiers, revinrent en toute discrétion au village, préparèrent quelques affaires, décampèrent dès l'aube sans laisser de traces, ils suivirent l'horizon, échouèrent ici à Séképembé où je me trouvais déjà, je les avais précédés dès que j'avais vu errer l'autre lui-même de mon jeune maître venu m'annoncer le départ imminent de ce village du Nord, je

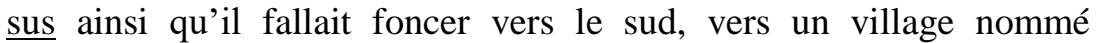
Séképembé, voilà comment nous sommes devenus bien malgré nous des habitants de ce village, un village d'accueil où nous aurions pourtant pu vivre une vie normale

Tradução: assim que os valentões voltaram ao vilarejo, foram surpreendidos ao escutar o anúncio da morte de Papai Kibandí, ninguém foi até a cabana do defunto, o cadáver do velho estava estendido na sala, os olhos exorbitados, revirados, e a língua, de uma cor azul índigo, se arrastava até sua orelha direita, o corpo já putrefato, um odor pestilento exalava ao redor, e por volta do fim do dia, quando começava a cair a noite, Mamãe Kibandí e meu jovem mestre enrolaram o cadáver em folhas de palmeira, o levaram longe na floresta, o enterraram num bananal, voltaram com toda discrição para o vilarejo, arrumaram algumas coisas, descamparam assim que amanheceu sem deixar traços, seguiram o horizonte, caíram aqui em Sêkêpembê onde eu já estava, eu os tinha precedido assim que vi errando o outro ele mesmo do meu jovem mestre vindo me anunciar a saída iminente desse vilarejo do Norte, soube então que era preciso ir em direção ao Sul, em direção a um vilarejo chamado Sêkêpembê, foi assim que nos tornamos a contragosto habitantes deste vilarejo, um vilarejo de acolhimento onde teríamos podido entretanto viver uma vida normal 
Nota-se que o passé simple é, de fato, o tempo verbal destinado a um passado definido e sem continuidade com o presente, usado junto ao imparfait, que descreve os fatos ocorridos, como vemos no trecho supracitado. Sabe-se que esse tempo caiu em desuso na língua oral, conforme define a gramática Le bon usage (GREVISSE, 1959, p.637): “3. O passé simple, cujas desinências por vezes heterogêneas produzem formas muito diferentes das dos outros tempos, desapareceu quase totalmente da língua falada, que o substituiu pelo imparfait e sobretudo pelo passé composê", ${ }^{74}$ permanecendo corrente, no entanto, na narração. Muito ligado à escrita, o passé simple não se limita, porém, aos textos literários, como diz a Grammaire Larousse du français contemporain (CHEVALIER, 1964, p.348): “Uso moderno. O passé simple é reservado à língua escrita; não é apenas próprio às obras literárias, é frequente na língua da 'imprensa escrita', da qual se estende à 'imprensa falada' do rádio e da televisão". ${ }^{75}$ Sendo o tempo da narrativa, observamos no entanto o seu uso não apenas em relatos escritos, mas também em relatos orais de narração de histórias, como é o caso dos contos de fada transmitidos oralmente às crianças. Considerando seus usos, percebe-se que, no romance, é condizente o seu emprego para narrar fatos ocorridos em um passado longíquo e terminado, e o uso do passé composé para os acontecimentos que ainda têm alguma relação com o tempo presente. O uso "tradicional" dos tempos verbais na narrativa mostra o domínio de Mabanckou em relação à língua francesa e, ao mesmo tempo, não distoa de sua intenção de aproximar-se da literatura oral, uma vez que mesmo oralmente, em situações de contação de histórias, essa formalidade narrativa se mantém.

Ademais da linguagem diferenciada, existem momentos privilegiados nos quais os relatos orais são mais importantes, e também algumas estruturas recorrentes. Segundo Chevrier (1986), tradicionalmente as histórias orais são contadas ao cair da noite, quando o corpo e o espírito já estão descansando, além de ser um momento que favorece a aproximação com os antepassados. Diz-se também que narrar uma história à luz do dia traz mau agouro ao contador. Além das histórias contadas cotidianamente ao

\footnotetext{
${ }^{74}$ No original: "3. Le passé simple, dont les désinences parfois hétéroclites produisent des formes trop différentes de celles des autres temps, a presque totalement disparu de la langue parlée, qui l'a remplacé par l'imparfait et surtout par le passé composé".

${ }_{75}$ No original: "l'usage moderne. Le passé simple est réservé à la langue écrite; il n'est pas seulement propre aux ouvrages littéraires, il est fréquent dans la langue de la "presse écrite", d'où il s'étend à la "presse parlée' de la radio et de la télévision".
} 
cair da noite, existem os relatos proferidos em situações especiais, solenes, tais como funerais, nascimentos, rituais de iniciação, caça, entre outros. Em MPE, o relato tem como causa a morte de Kibandí, acontecimento que é, para o narrador, especial e peculiar, digno de nota. Além disso, a narrativa tem como elemento central um ritual de iniciação, no qual o pequeno Kibandí recebe seus duplos (humano e animal) e bebe o líquido iniciático chamado mayamvumbí. O narrador explica que "a transmissão acontece desta maneira, primeiro entre os seres humanos, o iniciador e o iniciado por meio da absorção do mayamvumbí, depois entre os animais, o duplo animal do iniciador tendo que lamber o sexo do duplo animal de seu jovem iniciado" (MABANCKOU, 2006 , p.62). ${ }^{76} \mathrm{O}$ dia em que o ritual iniciático acontece, no romance, é contado em atmosfera de suspense, o jovem Kibandí sendo levado à força por seu pai para o meio da floresta, numa caminhada "interminável, pontuada pelo pio dos pássaros da noite" [interminable, ponctuée de cris d'oiseaux de nuit] (Ibid., p.81), em que o velho Kibandí desenterra um cantil com o líquido e o porco-espinho relata (Ibid., p.82):

\begin{abstract}
Papai Kibandí primeiro agitou o cantil várias vezes antes de despejar o mayamvumbí no copo, deu ele mesmo um gole, fez estalar a língua, estendeu em seguida o copo ao filho que recuou dois passos, "mas o que é que você está fazendo, hein, é pro seu bem, beba, beba logo" [...] alguns goles foram suficientes, a reação foi imediata, o pequeno Kibandí começou logo a ter vertigens, caiu no chão, se levantou, cambaleou, mal ficava em pé, os olhos fechados, o líquido tinha ao mesmo tempo gosto de vinho de palma estragado e de água do pântano, a poção queimava a garganta, e assim que abriu os olhos, o meu jovem mestre viu um garoto que se parecia com ele $^{77}$
\end{abstract}

Logo, a começar pela própria narrativa dos duplos, história central do livro, as transposições socioculturais que remetem às situações solenes de contação de histórias, crenças e rituais congoleses são várias, transportando o leitor para uma África mística. Outro exemplo seria a cena do ritual do cadáver delator de seu malfeitor, que é retratado assim (Ibid., p.141):

\footnotetext{
${ }^{76}$ No original: "la transmission se déroule de cette manière, d'abord entre les êtres humains, l'initiateur et l'initié à travers l'absorption du mayamvumbi, ensuite entre les animaux, le double animal de l'initiateur devant lécher le sexe du double animal de son jeune initié".

${ }^{77}$ No original: "Papa Kibandí secoua d'abord la gourde à plusieurs reprises avant de verser le mayamvumbi dans le gobelet, il avala lui-même une lampée, fit claquer sa langue, tendit ensuite la timbale à son fils qui recula de deux pas, 'mais qu'est-ce que tu fais, hein, c'est pour ton bien, bois, bois donc' [...] quelques gorgées avaient suffi, la réaction fut immédiate, le petit Kibandí éprouva aussitôt des vertiges, tomba par terre, se releva, chancela, il tenait à peine debout, les yeux fermés, le liquide avait à la fois le goût de vin de palme moisi et de la vase de marécage, la potion brûlait la gorge, et lorsqu'il ouvrit les yeux, mon jeune maître aperçut un gamin qui lui rassemblait".
} 
um feiticeiro designado pelo chefe do vilarejo segura um pedaço de madeira, bate três vezes sobre o caixão e pergunta ao cadáver "nos diga quem o comeu, mostre em qual cabana este malfeitor habita, você não pode ir embora assim para o outro mundo sem se vingar, então, ande, corra, voe, atravesse montanhas, planícies, e se o malfeitor habita para além do Oceano, e se ele habita com as estrelas, nós iremos até ele para que pague pelo mal que lhe fez a você e a sua família",78

Segundo Ngo Nlend e Fonkoua, essas transposições socioculturais permitem que o autor assinale "a presença e existência de outras culturas, de outros imaginários culturais" (2010, p.133-134). ${ }^{79} \mathrm{O}$ uso do passé simple, nessas cenas solenes, também ajuda a marcar a dramaticidade da situação. No que se refere aos diálogos, no entanto, vemos uma variação entre o uso do "vous", formal, e do "tu", informal. No trecho supracitado, por exemplo, o feiticeiro dirige-se ao cadáver utilizando "tu", informal, devido à situação em que se encontram e à relação entre as personagens feiticeirocadáver. Porém, em outras situações de diálogo nas quais as personagens não se conhecem ou nas quais existe uma hierarquia clara, ocorre o contrário. Por exemplo, na cena em que a irmã de Kibandí acredita que ele "comeu" sua própria sobrinha e, para ter certeza, recorre ao feiticeiro Tembê-Essuká a fim de encontrar provas (MABANCKOU, 2006, p.97):

Tia Etalelí se pôs de joelhos, começou a soluçar aos pés do feiticeiro, enxugava as lágrimas com a ajuda de um pedaço de pano amarrado em volta da lombar, o feiticeiro a repeliu "sejamos claros, este lar não é um lugar para as lágrimas, tem um pequeno cemitério mais para baixo, a senhora terá apenas o constrangimento da escolha para achar uma carcaça à qual as suas lágrimas darão prazer", Tia Etalelí balbuciou ainda assim "Tembê-Essuká, a morte da minha filha não é uma morte normal não, não é assim que uma pessoa deve morrer, eu lhe suplico, olhe bem, estou certa de que o senhor me ajudará, a sua ciência é a mais temida deste país" ${ }^{\prime 80}$

\footnotetext{
${ }^{78}$ No original: "un féticheur désigné par le chef du village se saisit d'un bout de bois, frappe trois coups sur la bière et demande au cadavre 'dis-nous qui t'a mangé, montre-nous dans quelle case ce malfaiteur habite, tu ne peux pas t'en aller comme ça dans l'autre monde sans te venger, alors, bouge, cours, vole, traverse les montagens, les plaines, et si ce malfaiteur habite au-delà de l'Océan, et s'il habite avec les étoiles, nous irons jusqu'à lui pour qu'il paye le mal qu'il t'a fait à toi et à ta famille'".

${ }^{79}$ No original: "la présence et l'existence d'autres cultures, d'autres imaginaires culturels".

${ }^{80}$ No original: "Tante Etalelí se mit à genoux, comença à sangloter aux pied du féticheur, elle s'essuyait les larmes à l'aide d'un bout de son pagne noué autour des reins, le féticheur la repoussa 'soyons clairs, cette demeure n'est pas un endroit pour les larmes, il y a un petit cimetière plus bas, vous n'aurez que l'embarras du choix pour trouver une carcasse à qui vos pleurs feraient plaisir', Tante Etalelí bredouilla tout de même 'Tembé-Essouka, la mort de ma fille n'est pas une mort normale, c'est pas comme ça qu'une personne doit mourir, je vous en supplie, regardez bien, je suis sûre que vous m'aiderez, votre science est la plus redoutée de ce pays"”.
} 
Nesse caso, ambas as personagens conversam entre si empregando o "vous" (ver o original na nota de rodapé), instaurando assim um diálogo formal. Nota-se que, na tradução, optamos por utilizar "senhor/a", mas os pronomes pertencentes à terceira pessoa do singular. Discorreremos mais sobre isso no Capítulo 3. Por ora, é importante frisar que existe, portanto, uma mescla entre elementos formais - o uso do passé simple e do pronome "vous" - e informais — nos diálogos, o uso do "tu" -, enfatizando a hierarquia entre as personagens e o tipo de relação que se estabelece entre elas, assim como ocorreria na linguagem oral dialogal.

O essencial, na literatura oral, é que o contador cative seu público, e é aí que mora sua arte. A relação que se estabelece entre o contador e sua audiência é primordial, pois o ensinamento do conto só perdurará se houver alguém para escutá-lo e, depois, transmiti-lo a outros. Muitas vezes o auditório já conhece a história, e assim o contador tem certa liberdade para modificar pequenos detalhes, introduzindo novas peripécias ou digressões. No livro, a relação do contador/narrador com seu público/leitor se dá por meio das tentativas do porco-espinho (narrador) de estabelecer uma conexão com a árvore (sua interlocutora) por intermédio de recursos típicos da sustentação do turno conversacional, principalmente no que se refere a marcadores de busca de aprovação ou de interação interpessoal. Podemos pensar na figura da árvore como representação do(s) leitor(es), uma vez que a narrativa é inteiramente dirigida a essa segunda pessoa ("tu") que, ainda que não responda ao monólogo, participa do jogo enunciativo. Tanto a árvore baobá quanto o leitor narratário são, portanto, destinatários diretos do discurso do narrador, participando da construção diegética. Ademais, na literatura oral, existem também os elementos extratextuais utilizados para tornar a história mais envolvente e prender a atenção do público, elementos dramáticos que caracterizam o estilo oral: posição do corpo, entonação da voz, gestos, aumento ou diminuição da voz (CHEVRIER, 1986, p.18). Utilizando esses elementos é possível enfatizar determinadas partes da narrativa, o que contribui para tornar o relato mais vivo.

Tanto no livro quanto na literatura oral, a linguagem nunca é impessoal, artificial, mas sim bastante gestual e simbólica, de maneira a criar um ambiente agradável e ganhar a empatia do público/leitor. Se a escrita de Mabanckou, nesse romance, segue os padrões tradicionais e formais em relação ao uso dos verbos, a informalidade aparece claramente quando o animal tenta estabelecer uma conexão com a árvore, pois vemos marcas de espontaneidade e imediatismo típicas de situações de 
comunicação face a face. Exemplos dessa comunicação implícita no livro são: "constatei com satisfação que a minha silhueta se mexia, seguia o ritmo dos meus membros, eu estava vivo, não tinha mais dúvidas sobre isso, e eu poderia ter ficado lá, juro, pois bem, não, não estava seguro, não queria fazer besteira” (MABANCKOU, 2006, p.31); ${ }^{81}$ ou: "ah não, quero então viver aqui e agora, viver tanto tempo quanto você, e depois, cá entre nós, não vou colocar fim aos meus dias sob o pretexto de que não teria mais direito à vida, você me entende, hein" (Ibid., p.42), ${ }^{82}$ ou: "na verdade, meu querido Baobá, naquela época eu não tinha partido do nosso território com a ideia de não mais voltar, juro que queria a vida em comunidade" (Ibid., p.59). ${ }^{83}$

Nos exemplos citados, as expressões em negrito mostram a intenção do narrador de buscar a aprovação e cumplicidade da árvore, e também a espontaneidade de seu discurso, principalmente com “juro, pois bem, não”, que indica hesitação. O vocativo "meu querido Baobá” [mon cher Baobab], ademais, marca a interação interpessoal entre as personagens, assim como o uso da $2^{\mathrm{a}}$ pessoa do singular ( $3^{\mathrm{a}}$ pessoa na tradução), que não só marca o direcionamento da fala do porco-espinho ao público/leitor, mas também a proximidade e informalidade dessa relação. Apesar das marcações direcionadas à árvore, esta de fato nunca responde ao porco-espinho - aliás, ele próprio se denomina uma "matraca sem interlocutor" [bavard sans interlocuteur] (Ibid., p.42) -, mas, em dado momento, já no fim da história, ele admite que é um alívio poder desabafar com alguém, ainda que não obtenha nenhuma resposta. É como se a árvore adquirisse, por fim, o papel de ancião curandeiro do narrador, responsável por escutar suas angústias e aliviar sua dor. $\mathrm{O}$ narrador demonstra nestas e em outras passagens ter sentimentos próprios aos humanos, como a angústia, o medo, a solidão, o que pode também ser visto como uma maneira de se aproximar do leitor, identificando-se com ele. Diz (Ibid., p.213):

quase não vi o passar do tempo desde ontem, me contentei em falar com você até que minhas pálpebras estivessem pesadas, você afinal não me interrompeu um só instante, ainda não sei entretanto o que

\footnotetext{
${ }^{81}$ No original: “j'ai constaté avec satisfaction que ma silhouette bougeait, suivait le rythme de mes membres, j'étais en vie, il n'y avait plus de doute à ce sujet, et j'aurais pu en rester là, je te jure, eh bien, non, je n'étais pas rassuré, je ne voulais pas commettre de bêtises".

${ }^{82}$ No original: "ah non, je veux donc vivre ici et maintenant, vivre aussi longtemps que toi, et puis, entre nous, je ne vais pas mettre fin à mes jours sous prétexte que je n'aurais plus droit à la vie, tu me comprends, hein".

${ }^{83}$ No original: “en fait, mon cher Baobab, à cette époque-là je n'étais pas parti de notre territoire avec l'idée de ne plus revenir, je te jure que je tenais à la vie en communauté".
} 
pensa dessa história, bom, de qualquer maneira, me sinto mais que aliviado porque pude me entregar, existem talvez coisas que eu não lhe disse aqui, por exemplo o meu apelido, o apelido que o meu mestre me atribuiu, ele me chamava de Ngumba ${ }^{84}$

e (Ibid., p.215):

só me arrependo de uma coisa, é de não escutar sua voz, meu querido Baobá, e se você pudesse falar como eu, me sentiria bem menos sozinho, mas o que conta a essa altura é a sua presença, ela me deixa menos angustiado ${ }^{85}$

Sobre os elementos dramáticos na escrita, nota-se que, sendo um texto escrito, Mabanckou faz menção aos gestos, voz e corpo do narrador através das palavras, aludindo à dramaticidade pertencente ao contador de histórias orais. Por exemplo, quando o narrador relembra os últimos momentos de vida de seu mestre e se emociona: "eu assistia, impotente, a sua agonia, a essa cena que ficou gravada na minha memória, desculpe a minha emoção, a minha voz trêmula, preciso de um momento para respirar" (Ibid., p.28), ${ }^{86}$ ou quando acaba de contar como deixou o mundo animal para tornar-se o duplo de Kibandí e ir viver com ele na cidade (Ibid., p.76):

foi assim, meu querido Baobá, que eu saí do mundo animal a fim de me colocar a serviço do pequeno Kibandí que acabava de ser iniciado em Mossaká, esse pequeno que eu iria seguir bem mais tarde em Sêkêpembê, esse pequeno que eu não iria mais largar durante décadas até a sexta-feira passada quando não pude fazer nada para evitar a sua morte, ainda estou afetado, não queria que me visse aos prantos, vou então virar de costas para você por decência e respirar um pouco antes de prosseguir $^{87}$

Nos dois exemplos supracitados temos uma pausa no discurso, marcada claramente pela inserção de um comentário a respeito disso, aludindo tanto à voz

\footnotetext{
${ }^{84}$ No original: "je n'ai presque pas vu le temps passer depuis hier, je me suis contenté de te parler jusqu'à ce que me paupières se soient alourdies, tu ne m'auras finalement pas interrompu un seul instant, je ne sais toutefois pas ce que tu penses de cette histoire, bon, quoi qu'il en soit, je me sens plus que soulagé parce que j'ai pu me livrer, il y a peut-être des choses que je ne t'ai pas dites ici, par exemple mon petit nom, le petit nom que m'avait attribué mon maître, il m'appelait Ngoumba".

${ }^{85}$ No original: "je ne regrette qu'une chose, c'est de ne pas entendre ta voix à toi, mon cher Baobab, et si tu pouvais parler comme moi, je me sentirais bien moins seul, mais ce qui compte à ce stade c'est ta présence, ele me rend moin angoissé".

${ }^{86}$ No original: "j'assistais, impuissant, à son agonie, à cette scène qui est restée gravée dans ma mémoire, excuse mon émotion, ma voix, qui tremble, je dois prendre un moment de respiration".

${ }^{87}$ No original: "voilà comment, mon cher Baobab, j'ai quitté le monde animal afin de me mettre au service du petit Kibandí qui venait d'être initié à Mossaká, ce petit que j'allais suivre bien plus tard à Séképembé, ce petit que je n'allais plus quitter pendant des décennies jusqu'au vendredi dernier où je n'ai pu rien faire pour lui éviter la mort, je suis encore affecté, je ne voudrais pas que tu voies mes larmes, je vais donc te tourner le dos par décence et souffler un peu avant de poursuivre".
} 
[minha voz trêmula/ ma voix qui tremble] quanto ao corpo [vou então virar de costas para você/ je vais donc te tourner le dos] do narrador.

Visualmente, no livro, essas pausas são seguidas por duas linhas em branco, ou aparecem no final de um capítulo, seguidas de uma página em branco até o começo do próximo (ver anexo). Esse espaço em branco, chamado também de "alínea", é um tópico polêmico entre os linguistas, que não estão de acordo sobre ela ser um sinal de pontuação ou não, mas há consenso em dizer que a alínea demarca uma mudança de tópico no discurso. Na verdade, inicialmente o parágrafo era marcado pela inserção de um sinal tipográfico e, ao longo do tempo, esse sinal foi substituído por esse espaço em branco. Assim, a alínea e o parágrafo, quando referentes ao sinal de separação entre dois blocos de texto, são similares, porém o parágrafo também remete à parte cheia do texto, distinguindo-se da alínea. No caso de $M P E$, quando falamos em alínea, estamos pensando nos espaços em branco entre um bloco de texto e outro, espaço que pode variar de tamanho conforme a diagramação de cada livro, é claro, mas que se manteve no comprimento de, no mínimo, uma linha em branco em todas as edições de $M P E$ consultadas. Dessa forma, dispensando a ajuda de um sinal tipográfico, a alínea, no romance, carrega em si fundamental importância, pois é responsável pelos respiros entre uma história e outra.

O ambiente propício para a atividade de contação de histórias pode variar entre uma casa grande o suficiente para acolher o público, uma área espaçosa na floresta ao pé de uma árvore ou o meio urbano, numa praça pública por exemplo. O público é introduzido à história por uma fórmula de abertura, na qual o contador instaura o universo do conto de maneira enigmática, quebrando com o espaço físico cotidiano e real. Muitas vezes essa introdução é feita por meio de adivinhas, cantos, charadas ou provérbios, e tem a função de chamar a atenção do público e convidá-lo a embarcar no mundo ficcional. No final do relato é comum que o contador introduza também uma fórmula de fechamento, que normalmente lembra o público do caráter anônimo da tradição oral, quer dizer, normalmente é uma fórmula fixa. No caso de $M P E$, não temos essas fórmulas introdutórias e de fechamento, porém é clara a referência ao ambiente mais característico das contações de histórias: uma área na floresta ao pé de uma árvore.

Ainda que as histórias possam ser contadas por qualquer pessoa não profissional, existem algumas figuras que costumam assumir essa posição, como músicos, historiadores, cantores etc. Existem etnias nas quais o contador é alguém de casta 
inferior, sendo às vezes desprezado, e outras nas quais acontece o contrário, sendo o contador alguém privilegiado e de grande prestígio. As subdivisões e variações são enormes, segundo os estudos feitos por Chevrier (1986). De maneira geral, pode-se dizer que o griot narra histórias passadas relacionadas à formação do mundo, dos impérios e dos homens ilustres. Como já dito anteriormente, a arte do griot varia segundo a região e as circunstâncias, mas ele tem sempre liberdade para modificar, encurtar ou alongar o relato, acrescentar ditos populares ou provérbios, de forma que a história contada nunca seja exatamente a mesma. O importante é que ele tenha segurança e não pare a história no meio, o que é considerado errado e nefasto.

A literatura oral tem a função primordial de divertir e descontrair. No entanto, isso não exclui sua função pedagógica, política e de iniciação. Muitos contos trazem à tona, por exemplo, um problema da comunidade, ou um ensinamento moral, religioso, social para os ouvintes. Normalmente a história se inicia com um conflito, que é resolvido ao longo do relato, e termina com um epílogo no qual é transmitida a moral social da história. Essa moral tem a intenção de manter a ordem na comunidade, de instaurar a norma e o bom senso transmitidos pelos detentores de poder. Não é por acaso, portanto, que as personagens das histórias são muitas vezes reis, príncipes ou sábios anciãos, estes também preocupados em manter a ordem no grupo social do qual são encarregados. Ainda que MPE seja ficcional, a personagem do velho governante porco-espinho poderia simbolizar o papel de um contador, já que traz ensinamentos e ordem à comunidade animal, representando o sábio ancião, assim como o próprio narrador, que dá o tom humorístico ao relato, divertindo seus ouvintes/leitores. Por exemplo, no trecho a seguir, quando o narrador começa a se distanciar da comunidade animal para tornar-se o duplo de Kibandí, nota-se a autoridade do velho porco-espinho e sua represália em relação à atitude do narrador (MABANCKOU, 2006, p.49-50):

eu provocava a cólera do nosso patriarca, ele estava cada vez mais intransigente [...] ele multiplicava doravante as reuniões, nos olhava de cima, levantava o tom de voz [...] nós não tínhamos nada a dizer já que a última palavra era dele, ele nos assegurava por exemplo que tal rio passava antigamente do outro lado, e assim que perguntávamos quanto tempo esse curso d'água demorou para fazer essa mudança espetacular o velho agitava os seus espinhos usados, fingia refletir de olhos fechados, nos mostrava o céu, eu, eu ria alto, isso o irritava a ponto de ele nos ameaçar, proferia o seu ultimato que nós conhecíamos de cor, "se é assim, não lhes direi mais nada sobre os homens e seus hábitos, vocês são uns ignorantes”, e como nós ainda 
ríamos ele acrescentava, enigmático, "quando o sábio mostra a lua, o imbecil olha sempre para o dedo" ${ }^{\prime 8}$

Vemos também a atitude de superioridade do velho governante neste outro trecho, no qual fica claro que sua presença e suas palavras eram levadas muito a sério pelos outros animais, mas não pelo próprio narrador, que diz que seus companheiros estavam "doutrinados" pelo governante, dando a entender que repetiam suas palavras sem questionamento (Ibid., p.52):

eu jamais caí nesses truques, senão não estaria aqui para lhe contar tudo isso, e então, os meus compadres, doutrinados pelo nosso governante, já imaginavam que eu iria cair nessas armadilhas, "o tambor é feito da pele do veadinho que se afastou da sua mãe", profetizava nosso australopiteco, persuadido de que eu não compreendia o sentido das suas palavras, e as suas afirmações suscitavam uma grande bagunça no grupo, vários compadres as repetiam a todo o tempo ${ }^{89}$

De maneira geral, o conteúdo das histórias orais remete à fauna e à flora, a narrativas da comunidade, mas existe sempre uma metáfora por trás da história aparente, de forma a introduzir a discussão de temas relacionados ao dia a dia da sociedade. Assim, as funções da literatura oral supracitadas dependem da leitura feita pelo público, que por sua vez pode variar conforme seu entendimento e conhecimento da cultura e dos códigos simbólicos da comunidade. Uma mesma narrativa pode ser interpretada de diferentes formas, e pode vir a desempenhar um papel fundamental na discussão e elaboração de certos aspectos sociais. O papel do contador é o de abrir a mente de seu público para o sentido metafórico do relato, instigando o auditório a refletir sobre temas e questões importantes, procurando soluções para a vida cotidiana. Em algumas passagens do romance, é o próprio narrador que questiona ações ou

\footnotetext{
${ }^{88}$ No original: “j'essuyais les colères de notre patriarche, il devenait de plus en plus intransigeant, [...] il multipliait désormais les rassemblements, nous prenait de haut, haussait le ton [...] nous n'avons rien à dire puisqu'il avait le dernier mot, il nous assurait par exemple que telle rivière passait jadis de l'autre côté, et lorqu'on lui demandait combien de temps ce cours d'eau avait pris pour opérer ce changement spectaculaire le vieillard brassait ses piquants usés, feignait de réfléchir les yeux fermés, nous montrait le ciel, moi j'en riais aux éclats, cela l'agaçait au point qu'il nous menaçait, proférait son ultimatum que nous connaissions par coeur, 'si c'est comme ça, je ne vous dirai plus rien au sujet des hommes et de leurs habitudes, vous n'êtes que des ignares', et puisque nous riions toujours il ajoutait, énigmatique, "quand le sage montre l alune, l'imbécile regarde toujours le doigt"'.

${ }^{89}$ No original: "je n'étais jamais tombé dans ces lacs, sinon je ne serais pas là à te parler de tout ça, et alors, mes compères, endoctrinés par notre gouverneur, s'imaginaient déjà que je me ferais prendre dans ces pièges, 'le tambour est fait de la peau du faon qui s'est éloigné de sa mère', prophétisait notre australopithèque, persuadé que je ne saisissais pas le sens de ces paroles, et ses propos suscitaient un grand vacarme dans le groupe, plusieurs compères les répétaient à tout bout de champ".
} 
comportamentos humanos, fazendo-nos refletir. Por exemplo, quando nos conta que os porcos-espinho podem viver mais quando estão em cativeiro, mas pondera: "qual o interesse de passar a vida em reclusão como um escravo, qual o interesse de imaginar a liberdade atrás das grades, hein" (Ibid., p.13) $;^{90}$ ou, já no final de seu relato, quando faz um balanço de sua vida e filosofa sobre o futuro, dizendo (Ibid., p.220-221):

meu querido Baobá, você deve me achar irrazoável, ambicioso, sobretudo irrealista quando pensa que tenho 42 anos hoje, e depois, palavra de porco-espinho, a idade não me dá medo, li no grosso livro de Deus que antigamente os humanos viviam durante séculos e séculos inteiros, o patriarca deles que chamavam de Matusalém viveu mesmo 969 anos, vou lhe dizer que não sou um porco-espinho acabado, gostaria de ser o Matusalém da espécie animal, ainda tenho resistência, agilidade, o negócio é que eu possa consagrar o tempo que me resta fazendo o bem, apenas o bem, me transformar talvez em duplo pacífico $^{91}$

O papel do conto nas comunidades tradicionais, por sua vez, é o de tentar levantar temas e questões já presentes na sociedade, sendo uma maneira lúdica de abordar problemas complexos e importantes. Existe, então, um caráter político por trás do simples relato ficcional, além do caráter social, já que os contos fornecem informações relativas à sociedade em questão, sejam elas veladas ou não, e em diversos âmbitos, como o religioso, ecológico, culinário, familiar. No caso de um romance como $M P E$, não se pode afirmar que existam funções para a narrativa com o intuito de levantar questões e resolver problemas, uma vez que a literatura não precisa ter função nenhuma, porém, conforme vimos, Mabanckou parece ter se apoiado na literatura oral, patrimônio cultural do continente africano, para escrever sua história, de forma a parodiar ou aludir a aspectos típicos dos contos e da tradição oral dos países africanos de expressão francesa.

Os gêneros da literatura oral africana não apresentam contornos muito definidos, muitas vezes distinguindo-se uns dos outros apenas pela natureza do texto, por sua estrutura ou por suas condições de apresentação e recepção. Alguns grupos étnicos

\footnotetext{
${ }^{90}$ No original: "quel intérêt de passer sa vie en réclusion tel un esclave, quel intérêt d'imaginer la liberté derrière des fils barbelés, hein".

${ }^{91}$ No original: "mon cher Baobab, tu dois me trouver déraisonable, ambitieux, surtout irréaliste quand tu penses que j'ai quarante-deux ans à ce jour, et puis, nom d'un porc-épic, l'âge ne me fait pas peur, j'ai lu dans le gros livre de Dieu que jadis les humains vivaient durant des siècles et des siècles entiers, leur patriarche qu'on appelait Mathusalem a même vécu 969 ans, c'est te dire que je ne suis pas encore un porc-épic fini, je voudrais être le Mathusalem de l'éspèce animale, j'ai encore de l'endurance, de l'agilité, le tout c'est que je puisse consacre le temps qui me reste à faire du bien, rien que du bien, à me transformer peut-être en double pacifique".
} 
dividem, ainda assim, os gêneros em dois grandes grupos: “de um lado mitos, fábulas e contos ligados [...] às sociedades iniciáticas e à magia, do outro a epopeia e a poesia lírica exprimindo a eclosão de civilizações urbanas e a tomada de consciência da dimensão histórica" (CHEVRIER, 1986, p.18). ${ }^{92}$ Ainda que os limites entre o conto e o mito sejam sutis e pouco claros, muitas são as considerações a respeito de suas diferenças. Teríamos o mito para retratar a origem do mundo, relacionando-se com o sobrenatural e com as forças da natureza, ao passo que, no conto, o real e o surreal tendem a se equilibrar, as personagens são tipos pertencentes à sociedade humana, e a estrutura (do conto) pode ser considerada como a forma profana do mito, correspondendo às modificações da sociedade ao longo do tempo.

O conto é o gênero mais difundido e popular no continente africano, o que faz com que existam muitas análises e classificações a respeito deles. Chevrier (1986) elenca alguns dos tipos elaborados por Denise Paulme em seu estudo inspirado na morfologia dos contos de Vladimir Propp. Segundo ela, a maioria dos contos parte de uma situação inicial de falta (pobreza, fome, solidão etc.) para chegar à negação da falta. A estudiosa elenca sete tipos de conto: ascendente, descendente, cíclico, espiral, espelhado, ampulheta e complexo. Em MPE, pode-se dizer que o tipo de conto que prevalece é o complexo, que nada mais é do que uma combinação de diversos elementos dos outros tipos enumerados. No que diz respeito à estrutura do romance, observamos uma série de aspectos macroestrtuturais referentes à tradição oral, dentre os quais destacamos as digressões, os provérbios (com itálicos e aspas) e as vírgulas.

A partir dessa análise faremos em seguida considerações sobre aspectos microestruturais envolvendo não apenas os provérbios, como as estruturas de paralelismo, as repetições e os neologismos. O conjunto dos aspectos macro e microestruturais, então, é responsável pelo "ritmo congolês" do qual fala o autor, ritmo este vindo dos elementos orais supracitados e da combinação tanto sintática e lexical quanto narrativa, conforme veremos.

\footnotetext{
${ }^{92}$ No original: "d'un côté mythes, fables et contes liés [...] aux sociétés initiatiques et à la magie, de l'autre épopée et poésie lyrique exprimant l'éclosion de civilisations urbaines et la prise en compte de la dimension historique".
} 


\title{
1. Oralidade na esfera macroestrutural
}

\subsection{Apresentação da história}

A situação inicial é a do narrador porco-espinho vivenciando um momento novo, após a morte de seu mestre Kibandí, portanto um momento de falta, de angústia, de solidão, de medo. No entanto, a narrativa não é linear, há vaivéns e digressões, nas quais o narrador relembra histórias de outras personagens, ou dele mesmo em outros momentos da vida, quer dizer, os acontecimentos são todos antigos, são memórias.

Para compreender o modo como se estrutura essa contação de histórias é importante salientar que o romance é baseado em uma narrativa da zona meridional da República do Congo, segundo diz Malonga (2007, p.125-126): "Mémoires de porc-épic se inspira na realidade etnológica do duplo protetor, o kibanda ou Kibandí (totem) em línguas da zona meridional da República do Congo, que veiculam muitas lendas". ${ }^{93}$ No livro, diz-se que todo homem possui um duplo animal, que pode servir para protegê-lo, sendo chamado de duplo pacífico, ou para executar por ele atos socialmente mal vistos, sendo nesse caso chamado de duplo nocivo. O narrador é um porco-espinho que pertence à segunda categoria, e assim executa no lugar de seu mestre inúmeros assassinatos na vila em que moram. Diz ele (MABANCKOU, 2006, p.16-17):

\begin{abstract}
pertenço antes ao grupo dos duplos nocivos, nós somos os mais agitados dos duplos, os mais perigosos, os menos comuns também, e como você pode adivinhar a transmissão de tal duplo é mais complicada, mais restrita, ela acontece ao longo do décimo ano de vida da criança, é preciso ainda fazer com que ela engula a bebida iniciática chamada mayamvumbí, o iniciado a beberá regularmente a fim de sentir o estado de embriaguez que o permite se duplicar, liberar seu outro ele mesmo, um clone bulímico que não para de correr, de cavalgar, de saltar rios, de se enterrar na folhagem quando não está roncando na cabana do iniciado, e eu, eu me encontrava no meio desses dois seres ${ }^{94}$
\end{abstract}

\footnotetext{
93 No original: “Mémoires de porc-épic s'inspire de la réalité ethnologique du double protecteur, le kibanda ou Kibandí (totem) en langues de la zone méridionale de la République du Congo, que véhiculent de nombreuses légendes".

${ }^{94}$ No original: “j'appartiens plutôt au groupe des doubles nuisibles, nous sommes les plus agités des doubles, les plus redoutables, les moins répandus aussi, et comme tu peux le deviner la transmission d'un tel double est plus compliquée, plus restreinte, ele s'opère au cours de la dixième année du gamin, encore faut-il parvenir à lui faire avaler le breuvage initiatique appelé mayamvumbi, l'initié le boira régulièrement afin de ressentir l'état d'ivresse qui permet de se dédoubler, de libérer son autre lui-même,
} 
A história começa no dia em que Kibandí morre e o animal se vê sozinho e sem rumo, angustiado, triste, até que depara com uma árvore baobá e resolve contar-lhe suas aventuras em tom confessional. O início é de supetão, como se fosse um relato começado anteriormente e que está apenas continuando (Ibid., p.11):

então eu sou só um animal, um animal de nada, os homens diriam uma besta selvagem como se não existissem outras mais bestas e mais selvagens que nós na espécie deles, para eles eu não passo de um porco-espinho, e como só acreditam naquilo que veem, deduziriam que não tenho nada de particular, que pertenço ao grupo de mamíferos munidos de longos espinhos, acrescentariam que sou incapaz de correr tão rápido quanto um cão de caça, que a preguiça me obriga a não viver longe do lugar onde me alimento ${ }^{95}$

Como vimos, a escolha do autor pela imagem do baobá não é aleatória: nas comunidades tradicionais africanas de expressão francesa as pessoas costumam sentarse ao redor de uma árvore, comumente um baobá, para discutir assuntos referentes à comunidade e para que os anciãos contem histórias. Dessa forma, a figura da árvore como receptora do monólogo do narrador é não somente uma maneira de remeter à tradição oral, mas também de mostrar a relação que se dá entre as personagens: o animal, inferior, imaturo, procura os conselhos de alguém mais experiente, vivido, o "ancião" da vila, que seria representado pela árvore. Em dado momento, logo depois de fazer uma grande digressão ${ }^{96}$ para refletir sobre a vida após a morte, entre outras coisas, conta à árvore o porquê de sua escolha de se refugiar ali (Ibid., p.43):

a minha escolha de me esconder ao seu pé não foi por acaso, não hesitei um só instante assim que o vi beirando o rio, me disse que seria ali que me abrigaria, quero na verdade tirar proveito da sua experiência de antepassado, só precisa ver as rugas que se entrelaçam em volta do seu tronco para compreender como você soube se adequar à alternância das estações, até mesmo as suas raízes se prolongam longe, bem longe no ventre da terra, e, de vez em quando, você agita os seus galhos para impor uma direção ao vento, lembrar à natureza que só o silêncio permite viver tanto tempo assim, e eu, palavra de

un clone boulimique sans cesse en train de courir, de cavaler, d'enjamber les rivières, de se terrer dans le feuillage quando il ne ronfle pas dans la case de l'initié, et moi je me retrouvrais au milieu de ces deux êtres".

${ }^{95}$ No original: “donc je ne suis qu'un animal, un animal de rien du tout, les hommes diraient une bête sauvage comme si on ne comptait pas de plus bêtes et de plus sauvages que nous dans leur espèce, pour eux je ne suis qu'un porc-épic, et puisqu'ils ne se fient qu'à ce qu'ils voient, ils déduiraient que je n'ai rien de particulier, que $\mathrm{j}$ 'appartiens au rang des mammifères munis de longs piquants, ils ajouteraient que je suis incapable de courir aussi vite qu'un chien de chasse, que la paresse m'astreint à ne pas vivre loin de l'endroit où je me nourris".

96 A digressão é também um recurso macroestruturante do modo de narrar de Mabanckou, que será tratado mais detalhadamente adiante. 
porco-espinho, eu estou aqui tagarelando, me espantando cada vez que uma folha morta escapa do seu topo ${ }^{97}$

Como o relato inteiro é dirigido a essa segunda pessoa que é a árvore, o leitor narratário se sente ele próprio o interlocutor, tomando o lugar do baobá e fazendo parte da história: o porco-espinho representaria o contador de histórias (o griot africano) e o leitor, seu público.

O narrador relata, assim, a história que começa no tempo em que seu mestre era apenas uma criança, tempo em que o pai dele havia um duplo nocivo na figura de um rato, que cometia por ele as maiores atrocidades possíveis. O porco-espinho conta sobre as violências e barbaridades cometidas por Papai Kibandí, sobre o ódio que a população da vila de Mossaká sentia por ele e sobre sua morte, ou melhor, assassinato. Também revela que foi o pai quem iniciou o jovem Kibandí no mundo dos duplos nocivos, num ritual de iniciação no qual a criança deve beber o líquido iniciático mayamvumbí, que faz o humano se duplicar. Porém, é apenas após a morte de seu pai e, anos depois, de sua mãe, que o jovem mestre assume finalmente seu "outro eu" e começa suas aventuras com seu duplo, o narrador, até o dia de sua morte.

O romance é dividido em seis partes de extensão variada, a saber: "como cheguei catastroficamente ao seu pé"; "como saí do mundo animal”; "como Papai Kibandí nos vendeu o seu destino"; “como Mamãe Kibandí se juntou a Papai Kibandí no outro mundo"; "como sexta-feira passada se tornou uma sexta-feira de tristeza" e "como ainda não sou um porco-espinho acabado". ${ }^{98}$ Dentro de cada uma dessas partes existe ainda a divisão dos parágrafos, que são visualmente separados por uma linha em branco, conforme já vimos, e a divisão por capítulos. A primeira parte se parece mais a um prólogo, no qual o narrador se apresenta, explica sobre os duplos nocivos e pacíficos e conta sobre sua vida junto à comunidade de porcos-espinho quando ainda fazia parte

\footnotetext{
${ }^{97}$ No original: "mon choix de me cacher à ton pied n'est pas le fait d'un hasard, je n'ai pas hésité un seul instant dès que je t'ai aperçu en longeant la rivière, je me suis dit que c'est là que je m'abriterai, je veux en fait tirer profit de ton expérience d'ancêtre, il n'y a qu'à voir les rides qui s'entremêlent autour de ton tronc pour comprendre comment tu as su jongler avec l'alternance des saisons, mêmes tes racines se prolongent loin, très loin dans le ventre de la terre, et, de temps à autre, tu remues tes branches pour imposer une direction au vent, rappeler à la nature que seul le silence permet de vivre aussi longtemps, et moi, nom d'un porc-épic, je suis là à bavarder, à m'épouvanter lorqu'une feuille morte s'échappe de ton faîte".

${ }^{98}$ No original: "comment je suis arrivé en catastrophe jusqu'à ton pied"; “ comment j'ai quitté le monde animal"; "comment Papa Kibandí nous a vendu son destin"; "comment Mama Kibandí a rejoint Papa Kibandí dans l'autre monde"; "comment le vendredi dernier est devenu un vendredi de malheur" e "comment je ne suis pas encore un porc-épic fini".
} 
do mundo animal. Também é nesse momento que o narrador explica por que decidiu se sentar ao pé do baobá. É aí que aparece o maior número de digressões, pois o narrador mistura sua narrativa presente, após a morte de Kibandí, com lembranças do tempo em que seu mestre ainda estava vivo. Na segunda parte, "como saí do mundo animal", nos conta como se deu a transição de sua vida na comunidade animal para a convivência com os humanos, quando assumiu o posto de duplo de Kibandí. A mudança de ambiente é fortemente marcada por um questionamento identitário, que fica claro nessa parte quando ele começa a se misturar com seu mestre, transformando-se e perdendo sua identidade de porco-espinho comum. Em "como Papai Kibandí nos vendeu o seu destino", nos conta sobre o ritual iniciático, no qual o pequeno Kibandí recebe seu “outro ele mesmo", assim como seu pai também recebera quando jovem. Nessa parte o pequeno Kibandí passa pela infância e pela adolescência, períodos tranquilos de sua vida em que seu duplo, o porco-espinho, apenas o observa e o segue sem muito que fazer. Nesse período, os assassinatos eram cometidos por Papai Kibandí, que possuía um duplo sob forma de rato. $\mathrm{O}$ narrador nos relata as inúmeras mortes cometidas por ele, incluindo a morte de sua sobrinha e a ida ao feiticeiro Tembê-Essuká para solucionar o mistério. Essa parte termina com Papai Kibandí que, sendo odiado pela população do vilarejo de Mossaká, tem seu duplo animal, o rato, morto e, por conseguinte, morre também. Devido a isso, o pequeno Kibandí, sua mãe e o narrador têm de se mudar para Sêkêpembê.

Na parte "como Mamãe Kibandí se juntou a Papai Kibandí no outro mundo" Kibandí ainda não assume seu lado maligno. Após a morte de seu pai, se muda para o novo vilarejo com Mamãe Kibandí e aprende o ofício de carpinteiro, enquanto a mãe tece tapetes para vender. Nesse momento o narrador nos relata já alguns feitos curiosos de Kibandí, por exemplo ser muito bom em carpintaria sem nunca ter feito isso antes, ou conseguir ler a Bíblia sem nunca ter aprendido a ler. Feitos como esses começam a indicar aos aldeões que o pequeno Kibandí tem "alguma coisa", segundo o narrador. Essa parte acaba com a morte de Mamãe Kibandí, que sofria do coração, e é então que o outro ele mesmo de Kibandí começa a se mostrar mais presente, dando sinal de que a vida do duplo irá começar.

A parte "como sexta-feira passada se tornou uma sexta-feira de tristeza" é enfim o momento em que o pequeno Kibandí assume sua dupla identidade e, então, o narrador, seu duplo, passa a ser a personagem central de suas peripécias macabras, 
executando por ele os mais estranhos assassinatos. É aí que conhecemos a história de Amêdê, o jovem letrado arrogante, da bela Kiminú, que recusou o amor de Kibandí, do velho extrator de vinho que queria trapacear Kibandí, de Yulá, que devia dinheiro a Kibandí, e muitos outros, todos assassinados pelas mais diversas razões. Essa parte termina com a história de Koty e Kotê, os gêmeos que desvendaram a identidade assassina de Kibandí e acabaram por matá-lo.

A parte final, "como ainda não sou um porco-espinho acabado", é a mais curta, parecendo um epílogo. Nela, o porco-espinho já terminou de contar a história de sua vida como duplo até a morte de seu mestre, e então filosofa sobre tudo o que viveu e sobre o que quer para o futuro. É nesse momento que nos revela que falar com a árvore foi uma espécie de terapia, pois se sentia muito angustiado e precisava conversar com alguém.

É interessante observar também que o parágrafo final de cada uma das partes é majoritariamente composto por uma digressão, na qual o narrador explica que fará uma pausa, marcada, então, pela mudança de página e pela introdução de um novo título. Sendo o recurso da digressão notadamente um dos elementos macroestruturais mais importantes na narrativa, analisaremos o seu uso mais detidamente a seguir.

\subsection{Digressões}

A digressão é utilizada pelo narrador em diferentes momentos, principalmente quando deseja fazer uma pausa em seu relato para respirar ou descansar e quando se lembra de outra história relacionada aos fatos ou apenas ilustrativa e resolve contá-la.

No primeiro caso, conforme vimos, o narrador remete a elementos gestuais, corporais e de entonação, próprios da literatura oral, aproximando-se assim desse universo e cativando seu público. Por exemplo, ao final de um capítulo no qual está contando sobre os assassinatos que efetuou para seu mestre e sobre a dificuldade de executar a centésima missão, ele anuncia finalmente qual seria o famigerado crime ao dizer (Ibid., p.186): 
há pouco com os seus dois filhos, uns gêmeos que, dizia ele, lhe faltavam ao respeito, o meu mestre estava então longe de saber que ele acabava de assinar a sua sentença de morte ${ }^{99}$

Logo depois, porém, no início do capítulo seguinte, ao invés de continuar essa narração, faz antes uma pequena digressão para dizer: "palavra de porco-espinho, como o tempo passa rápido, estou rouco, a noite já caiu sobre Sêkêpembê, e eu aqui chorando sem compreender por que, a solidão me pesa desta vez, me sinto culpado de não ter nada feito para salvar o meu mestre" (Ibid., p.187). ${ }^{100}$ Nesse trecho, além de referir-se à sua voz rouca, clara alusão à fala, vemos também o sentimento de culpa do narrador em relação aos atos que cometeu ou deixou de cometer. O recurso da digressão é usado, nesse e em outros trechos, como forma não apenas de fazer uma pausa, mas também de se explicar, se redimir ou se isentar de suas missões inescrupulosas. Ao se confessar culpado, o narrador se aproxima do público, cativando sua audiência assim como fazem os contadores de história.

No segundo caso mais comum de digressão, temos o recurso tal qual é utilizado no nosso dia a dia quando contamos uma história oralmente. Em muitos momentos, mudamos o rumo do relato para contar outra história que lembramos no meio do caminho, como podemos ver no trecho a seguir, na primeira parte da narrativa, quando o porco-espinho conta como era sua vida na savana, antes de se tornar duplo de Kibandí e, interrompendo o relato, diz (Ibid., p.21):

sim eu era um porco-espinho feliz nessa época, e eu eriço os meus espinhos enquanto o afirmo, o que é uma maneira para nós de jurar, ou então nós levantamos a pata direita e a agitamos três vezes seguidas, eu sei que os humanos costumam, eles, colocar em jogo a cabeça de seus defuntos ou convocar seu Deus que eles jamais viram e adoram de olhos fechados, eles consagram assim a sua existência a ler Suas palavras reportadas num livro grosso ${ }^{101}$

\footnotetext{
${ }^{99}$ No original: "il m'a rappelé que je devais ratrapper le coup, que je devais m'attaquer cette fois-ci à la famille Moundjoula, un couple arrivé à Séképembé depuis peu avec leurs deux enfants, des jumeaux qui, prétendait-il, lui manquaient de respect, mon maître était alors loin de savoir qu'il venait de signer son acte de décès".

${ }^{100}$ No original: "nom d'un porc-épic, qu'est-ce que le temps passe vite, j'ai la voix enrouée, la nuit est déjà tombée sur Séképembé, voilà que je pleure sans comprendre pourquoi, la solitude me pèse pour une fois, je me sens coupable de n'avoir rien fait pour sauver mon maître".

${ }^{101}$ No original: "oui j'étais un porc-épic heureux en ce temps-là, et je dresse mes piquants lorsque je l'affirme, ce qui est une manière pour nous de jurer, autrement nous levons aussi la patte droite et l'agitons trois fois de suíte, je sais que les humains ont l'habitude, eux, de mettre en jeu la tête de leurs défunts ou de convoquer leur Dieu qu'ils n'ont jamais vu et qu'ils adorent les yeux fermés, ils consacrent ainsi leur existence à lire Ses paroles rapportées dans un gros livre".
} 
Na continuação, o narrador discorre por três páginas sobre seus conhecimentos religiosos, dando sua opinião sobre a crença dos humanos em Deus, o que, a priori, nada tem que ver com a história do livro, mas diz muito sobre a caracterização do narrador: irônico, inteligente, culto, prolixo. Assim, vemos a digressão como maneira de aprofundar o conhecimento em relação às personagens, também marcando a intenção do narrador de aproximar-se de seu público e ganhar sua confiança e simpatia. Em dado momento, o recurso é explicitamente usado pelo porco-espinho quando se dirige à árvore, também nesse caso procurando uma aproximação e mostrando sua personalidade irônica (Ibid., p.151):

gostaria muito de remontar a sua genealogia, saber de qual árvore você descende e em qual lugar viveram os seus primeiros antepassados, mas talvez eu esteja me distanciando um pouco das minhas próprias confissões ao falar de você, hein, é ainda minha parte humana que se exprimiu, na verdade eu aprendi com os homens o sentido da digressão, eles não vão jamais direito ao assunto, abrem parênteses que se esquecem de fechar ${ }^{102}$

Não iremos nos estender nos exemplos de digressão, pois são muito numerosos. Vale dizer, no entanto, que o lugar que ocupam na narrativa é o de, por vezes, pausar a linearidade do relato do porco-espinho, outras vezes, divergir da história central para contar outros causos a fim de aproximar-se de seu leitor/árvore, buscando identificação e cumplicidade a partir de confissões ou de histórias focadas nos sentimentos e caracterização das personagens, assim como faziam os contadores de histórias tentando cativar sua audiência. Temos, também, o uso dos provérbios, que podem ser pensados em articulação com as digressões. Trataremos deles a seguir.

\subsection{Intertextualidade: provérbios e alusões literárias}

Em MPE, o uso dos provérbios (ou paremias, como veremos no Capítulo 3) é evidente e preponderante, e, portanto, vale ressaltar sua importância na obra. Aparecem majoritariamente nas partes 1 e 2 , ou seja, no começo do relato, momento em que o narrador ainda está conquistando seu público e se fazendo conhecer. Nada mais justo do

\footnotetext{
${ }^{102}$ No original: “ $\mathrm{j}$ 'aimerais tant remonter ta généalogie, savoir de quel arbre tu descends et dans quel lieu vécurent tes premiers ancêtres, mais peut-être me suis-je un peu éloigné de mes propres confessions en parlant de toi, hein, c'est encore ma part humaine qui s'est exprimée, en effet j'ai appris des hommes le sens de la digression, ils ne vont jamais au but, ouvrent des parenthèses qu'ils oublient de refermer".
} 
que fazer uso de todos os recursos que puder para atingir seu objetivo. Veremos, a seguir, qual a função dos provérbios na comunidade tradicional congolesa e em que momentos aparecem na narrativa, e de que forma remetem a esse universo. ${ }^{103}$

O provérbio é uma formulação típica da tradição oral africana, é um modo de dizer as realidades percebidas a nossa volta (XATARA, OLIVEIRA, 2002) e está diretamente relacionado à cultura e a sua situação de enunciação. Segundo Leguy, "percebemos rapidamente ao escutar um dito proverbial em situação que não é a forma que faz o provérbio, mas antes a pertinência de uma alusão em relação a um contexto dado" (2004, p.135). ${ }^{104}$ Ou seja, o enunciado se torna provérbio dentro de um contexto específico e, apesar de sua forma ser muitas vezes semelhante, não é determinante para sua definição.

Levando isso em consideração e observando os enunciados proverbiais do romance, concluímos que, na narrativa, eles têm valor proverbial devido justamente a seu contexto de uso, ao momento em que aparecem e também a sua estrutura gramatical. Achamos viável considerar a hipótese de que Mabanckou parodiou e/ou modificou alguns provérbios existentes, de forma a criar enunciados novos que remetam a esse universo. Por exemplo, na página 71 do romance, temos "un animal averti en vaut deux" [um animal prevenido vale por dois], enunciado que teria dito o velho governante aos outros porcos-espinhos para tentar convencê-los da necessidade de migração devido aos caçadores na região. O provérbio original seria "un homme averti en vaut deux", mas Mabanckou o modifica para incorporá-lo na história do narrador, que é um animal. O que deve ser retido aqui é o uso que o narrador faz desse recurso: em que momento utiliza os provérbios? Com qual finalidade?

Nota-se que, nas sociedades orais, os provérbios são proferidos por um ancião, um chefe, um líder, um sábio, ou seja, alguém com autoridade e sabedoria. Nas narrativas, ele é muitas vezes introduzido por uma fórmula que coloca as palavras na boca de outro, por exemplo "como diria fulano" e outras variações, o que dá mais credibilidade e ajuda no seu reconhecimento. Em MPE, observamos o uso dessa fórmula quando o narrador se apropria dos ensinamentos do velho porco-espinho que o

\footnotetext{
${ }^{103}$ Parte da análise a seguir foi publicada no artigo de minha autoria intitulado "A tradução de provérbios em Alain Mabanckou", Revista Non Plus, n.7, p.54-66, 2015.

${ }^{104}$ No original: “On s'aperçoit vite en écoutant le dire proverbial en situation que ce n'est pas la forme qui fait le proverbe, mais plutôt la pertinence d'une allusion en rapport à un contexte donné".
} 
governava para citar os provérbios, que aparecem então entre aspas e em itálico, logo após a referência às palavras do velho animal. Esse recurso faz clara alusão à sabedoria dos anciãos, sendo a personagem do governante caracterizada como alguém sábio e com autoridade dentro da comunidade animal a partir desses enunciados. Por exemplo, quando o narrador se questiona sobre o futuro, sem saber quanto tempo ainda irá viver, e então se lembra das palavras do velho porco-espinho, "quanto tempo deveria eu viver agora, hein, não sei de nada, meu querido Baobá, 'a cada dia basta sua pena', teria dito nosso velho governante" (MABANCKOU, 2006, p.217), ${ }^{105}$ ensinamento que teria influenciado a vida do narrador.

Em relação ao uso das aspas e do itálico nesses enunciados, podemos tecer algumas considerações. O itálico é um marcador expressivo que enfatiza um argumento ou, conforme diz Dahlet (2006, p.186), atribui “à palavra ou expressão um peso expressivo". Já as aspas, também segundo o estudo feito por Dahlet, "bloqueiam a interpretação literal do segmento" e "tem função de acentuar/ ressaltar uma palavra ou expressão" (Ibid., p.182). Podem aparecer de duas formas: 1) aspas autonímicas, em que a palavra aspeada se refere a si mesma; 2) aspas de conotação autonímica, em que a palavra ou expressão aspeada é dita pelo enunciador, mas não é propriamente dele, ou seja, há um distanciamento do enunciador. Este é o caso em MPE, o que, por fim, corrobora a ideia de que os enunciados proverbiais têm destaque dentro da narrativa. Os enunciados, sejam eles parodiados ou não, são ditos por personagens de autoridade e são embasados pelo uso do itálico, que os ressalta, e das aspas, que deixam evidente que aquele dito não foi falado pelo próprio narrador, mas que, no entanto, ele está de acordo com o argumento e, assim, o utiliza para ilustrar ou enfatizar uma ideia.

Ancorados nessa sabedoria tradicional, muitos provérbios africanos de expressão francesa - como se pode ver no romance - apresentam conteúdo de ensinamento, advertência ou conselho e são usados para reforçar um argumento, invocar autoridade, admoestar, instruir, aconselhar ou prevenir (STEINBERG, 1995). Segundo Chevrier (1984), esse recurso tem finalidade moral dentro das comunidades africanas de expressão francesa, e serve para deixar o relato mais autêntico. Por exemplo, na primeira parte de $M P E$, o narrador faz uso de um provérbio para reforçar o argumento de que ele provavelmente morreria em breve, já que Kibandí havia morrido e

\footnotetext{
${ }^{105}$ No original: "combien de temps devrais-je maintenant vivre, hein, je n'en sais rien, mon cher Baobab, "à chaque jour suffit sa peine", aurait dit notre vieux gouverneur".
} 
normalmente o duplo morre logo em seguida de seu mestre. Diz: "fiquei na hora enlouquecido porque, como teria dito nosso velho governante em seu tempo, 'quando se cortam as orelhas, o pescoço deveria se preocupar", (MABANCKOU, 2006, p.29). ${ }^{106}$ Por ser um dito do velho governante, esse provérbio também tem a função de invocar a autoridade e definir os papéis das personagens: o velho porco-espinho representa o sábio ancião a quem os mais novos recorrem para conselhos e ensinamentos, e o narrador porco-espinho representa um aprendiz, alguém que está se servindo desses ditos para resolver seus próprios problemas e dilemas.

Elaboramos a tabela 1, a seguir, para apresentar os provérbios e suas traduções, ${ }^{107}$ bem como o lugar em que aparecem na narrativa. Ao elaborá-la, ficou evidente a relevância que os ditos têm nos momentos em que o narrador está mais frágil, triste e angustiado. Eles aparecem majoritariamente nas duas primeiras partes, "como cheguei catastroficamente ao seu pé” e "como saí do mundo animal", momentos em que o animal está conquistando a confiança da árvore, além de estar ainda bastante desestabilizado devido à morte de Kibandí.

$\mathrm{Na}$ primeira parte, principalmente, os enunciados são conselhos ou recomendações do velho porco-espinho governante com o intuito de alertar ou amedrontar o narrador, ou ainda ajudá-lo a se fortalecer. São mais melancólicos, condizentes com o momento inicial de tristeza da personagem. Na segunda parte, quando o narrador está em transição para o mundo dos humanos na função de duplo nocivo, os provérbios transmitem ainda mais a mensagem de alerta, revelando a precaução e a insegurança do animal durante essa mudança de identidade.

Note-se que inexistem enunciados proverbiais nas partes "como Papai Kibandí nos vendeu o seu destino" e "como Mamãe Kibandí se juntou a Papai Kibandí no outro mundo", que são justamente as partes em que o animal finalmente conta suas peripécias enquanto duplo nocivo. Pode-se pensar que são nessas partes que a história de fato acontece: há trama, enquanto nas outras há digressão. Os poucos provérbios que aparecem nas duas partes finais do romance, "como sexta-feira passada se tornou uma sexta-feira de tristeza" e "como ainda não sou um porco-espinho acabado", destoam consideravelmente dos iniciais. Nesse momento final, vemos enunciados mais

\footnotetext{
${ }^{106}$ No original: “j'ai été aussitôt saisi d'affolement parce que, comme aurait dit notre vieux gouverneur en son temps, 'quand on coupe les oreilles, le cou devrait s'inquiéter"'.

${ }^{107}$ Os comentários de tradução serão feitos no Capítulo 3.
} 
esperançosos, tranquilos, que transmitem a atmosfera da personagem, tendo já se confessado e aliviado sua angustia. Vejamos:

Tabela 1 - Provérbios (paremias)

\begin{tabular}{|c|c|c|}
\hline Parte & Original & Tradução \\
\hline \multirow[t]{5}{*}{$\begin{array}{l}\text { como cheguei } \\
\text { catastroficamente } \\
\text { ao seu pé }\end{array}$} & $\begin{array}{l}\text { la douceur du miel ne consolera } \\
\text { jamais de la piqûre d'abeille (p. } \\
\text { 13) }\end{array}$ & $\begin{array}{l}\text { a doçura do mel não consolará jamais a } \\
\text { picada de abelha }\end{array}$ \\
\hline & $\begin{array}{l}\text { si tu veux que Dieu se marre, } \\
\text { raconte-lui tes projets (p. 24) }\end{array}$ & $\begin{array}{l}\text { se você quer que Deus se divirta, conte } \\
\text { a ele os seus projetos }\end{array}$ \\
\hline & $\begin{array}{l}\text { ce n'est pas parce que la mouche } \\
\text { vole que cela fera d'elle un oiseau } \\
\text { (p. 26) }\end{array}$ & $\begin{array}{l}\text { não é porque a mosca voa que isso fará } \\
\text { dela um pássaro }\end{array}$ \\
\hline & $\begin{array}{l}\text { quand on coupe les oreilles, le cou } \\
\text { devrait s'inquiéter (p. 29) }\end{array}$ & $\begin{array}{l}\text { quando se cortam as orelhas, o pescoço } \\
\text { deveria se preocupar }\end{array}$ \\
\hline & $\begin{array}{l}\text { à force d'espérer une condition } \\
\text { meilleure, le crapaud s'est retrouvé } \\
\text { sans queue pour l'éternité (p. 39) }\end{array}$ & $\begin{array}{l}\text { de tanto esperar uma condição melhor, } \\
\text { o sapo ficou sem rabo por toda a } \\
\text { eternidade }\end{array}$ \\
\hline \multirow[t]{12}{*}{$\begin{array}{l}\text { como saí do } \\
\text { mundo animal }\end{array}$} & $\begin{array}{l}\text { quand le sage montre la lune, } \\
\text { l'imbécile regarde toujours le doigt } \\
\text { (p. 49-50) }\end{array}$ & $\begin{array}{l}\text { quando o sábio mostra a lua, o imbecil } \\
\text { olha sempre para o dedo }\end{array}$ \\
\hline & $\begin{array}{l}\text { le tambour est fait de la peau du } \\
\text { faon qui s'est éloigné de sa mère (p. } \\
52 \text { ) }\end{array}$ & $\begin{array}{l}\text { o tambor é feito da pele do veadinho } \\
\text { que se afastou da mãe }\end{array}$ \\
\hline & $\begin{array}{l}\text { le poisson qui parade dans } \\
\text { l'affluent ignore qu'il finira tôt ou } \\
\text { tard comme poisson salé vendu au } \\
\text { marché (p. 54) }\end{array}$ & $\begin{array}{l}\text { o peixe que desfila no afluente ignora } \\
\text { que acabará cedo ou tarde como um } \\
\text { peixe salgado vendido no mercado }\end{array}$ \\
\hline & $\begin{array}{l}\text { fit du plaisir que la crainte peut } \\
\text { corrompre (p. 65) }\end{array}$ & $\begin{array}{l}\text { despreze o prazer que o medo pode } \\
\text { corromper }\end{array}$ \\
\hline & $\begin{array}{l}\text { que sert la bonne chère quand on } \\
\text { n'a pas la liberté (p. } 65 \text { ) }\end{array}$ & $\begin{array}{l}\text { para que serve a fartura quando não se } \\
\text { tem a liberdade }\end{array}$ \\
\hline & $\begin{array}{l}\text { nous ne croyons le mal que quand il } \\
\text { est venu (p. 66) }\end{array}$ & $\begin{array}{l}\text { nós só acreditamos no mal quando ele } \\
\text { chega }\end{array}$ \\
\hline & $\begin{array}{l}\text { vous ne comprendrez rien à rien, } \\
\text { seul le vieux sage peut entendre le } \\
\text { criquet éjaculer (p. 67) }\end{array}$ & $\begin{array}{l}\text { vocês não entendem nada de nada, } \\
\text { somente o velho sábio pode escutar o } \\
\text { grilo ejacular }\end{array}$ \\
\hline & $\begin{array}{l}\text { les petits du tigre ne naissent pas } \\
\text { sans leurs griffes (p. } 70 \text { ) }\end{array}$ & $\begin{array}{l}\text { os filhotes do tigre não nascem sem as } \\
\text { suas garras }\end{array}$ \\
\hline & $\begin{array}{l}\text { un animal averti en vaut deux (p. } \\
71 \text { ) }\end{array}$ & um animal prevenido vale por dois \\
\hline & $\begin{array}{l}\text { Et si vous voyez un sourd courir, } \\
\text { mes petits, ne vous posez pas de } \\
\text { questions, suivez-le car il n'a pas } \\
\text { entendu le danger, il l'a vu (p. } 71 \text { ) }\end{array}$ & $\begin{array}{l}\text { e se virem um surdo correr, meus } \\
\text { pequenos, não façam perguntas, o } \\
\text { sigam pois ele não escutou o perigo, } \\
\text { ele o viu }\end{array}$ \\
\hline & $\begin{array}{l}\text { l'orgueil ne donnera jamais de logis } \\
\text { à un vagabond (p. 74) }\end{array}$ & $\begin{array}{l}\text { o orgulho não dará jamais casa a um } \\
\text { vagabundo }\end{array}$ \\
\hline & $\begin{array}{l}\text { le logis du vagabond c'est ça } \\
\text { dignité (p. 74) }\end{array}$ & a casa do vagabundo é a sua dignidade \\
\hline
\end{tabular}




\begin{tabular}{|l|l|l|}
\hline $\begin{array}{l}\text { como sexta-feira } \\
\text { passada se tornou } \\
\text { uma sexta-feira de } \\
\text { tristeza }\end{array}$ & $\begin{array}{l}\text { assieds-toi au pied d'un baobab et, } \\
\text { avec le temps, tu verras l'Univers } \\
\text { defiler devant toi" (p. 149) }\end{array}$ & $\begin{array}{l}\text { senta-te ao pé de um baobá e, com o } \\
\text { tempo, verás o Universo desfilar diante } \\
\text { de ti }\end{array}$ \\
\cline { 2 - 3 } & $\begin{array}{l}\text { un lâche vivant vaut mieux qu'un } \\
\text { héros mort (p. 187) }\end{array}$ & $\begin{array}{l}\text { um covarde vivo vale mais que um } \\
\text { herói morto }\end{array}$ \\
\hline $\begin{array}{l}\text { como ainda não } \\
\text { sou um porco- } \\
\text { espinho acabado }\end{array}$ & $\begin{array}{l}\text { à chaque jour suffit sa peine (p. } \\
\text { 217) }\end{array}$ & a cada dia basta sua pena \\
\hline
\end{tabular}

Observa-se que os provérbios proferidos pelo narrador, por Kibandí ou pelo velho governante têm valor de "citação de autoridade", são "lançados", como diz o narrador, quando a personagem quer garantir a autoridade de seu enunciado. Segundo Xatara e Oliveira (2002), o provérbio, sendo aprovado e utilizado pela massa, ganha status de opinião comum, de verdade universal. Assim sendo, na narrativa esse tipo de enunciado é utilizado pelo narrador, dando voz a outras personagens ou proferindo ele mesmo o enunciado, de maneira a recriar o universo tradicional e remeter à cultura oral africana de expressão francesa, na qual os ditos e provérbios são marca de sabedoria, revelando o enraizamento do indivíduo em sua cultura.

Os provérbios são responsáveis, também, por criar a atmosfera polifônica no romance, uma vez que o "eu" enunciativo do narrador passa a palavra para outras personagens ao fazer referência aos provérbios, e não somente a eles, mas também a contos, fábulas, máximas congolesas e de outras culturas.

Além das referências às fábulas de La Fontaine, conforme vimos anteriormente, são muitas as referências a textos literários. Alguns exemplos seriam: "foi também Amêdê quem contou a eles várias vezes a história de um garoto que se deslocava num tapete voador, de um patriarca que criou um vilarejo chamado Macondo e cuja descendência ia afundar numa espécie de maldição" (MABANCKOU, 2006, p.156: referência a Aladin e a Gabriel García Márquez); ${ }^{108}$ "ele não deixava de lhes dizer na sequência a história trágica de um duplo assassinato numa rua chamada bizarramente de 'Morgue"” (Ibid., p.157: referência a Edgar Allan Poe); 109 “[Kibandí] me chamou uma noite e me disse 'olha, amanhã, assim que amanhecer, na hora em que o campo clareia,

\footnotetext{
${ }^{108}$ No original: “c'est toujours Amédée qui leur racontait à plusieurs reprises l'histoire d'un gars qui se déplaçait sur un tapis volant, d'un patriarche qui créa un village appelé Macondo et dont la descendance allait sombrer dans une espéce de malédiction".

${ }^{109}$ No original: "il ne manquait pas de leur lire dans la foulée l'histoire tragique d'un double assassinat dans une rue appelée bizarrement 'Morgue"'.
} 
quero que você siga esse extrator de vinho de palma besta"” (Ibid., p.171: alusão literária à Les contemplations, de Victor Hugo); ${ }^{110}$ ou à Bíblia (Ibid., p.21-22):

parece que o meu mestre Kibandí possuía esse livro de Deus no qual existem várias histórias que os homens são forçados a crer com o risco de não merecerem um lugar no que eles chamam de o Paraíso, você duvida que eu tenha metido meu nariz lá dentro por curiosidade já que eu podia ler correntemente como o meu mestre, me acontecia aliás de ler em seu lugar quando ele estava esgotado ${ }^{111}$

\subsection{Pontuação: vírgulas}

Em $M P E$ a vírgula é o único sinal de pontuação utilizado, e isso não é aleatório. No estudo feito por Dahlet (2006), vemos que a vírgula é um sinal de pontuação que pode ter a função de marcar uma "pausa de pequena duração", segundo a definição de Cunha, uma "pausa mais fraca", conforme diz Said, uma "pausa que não quebra a continuidade do discurso", de acordo com Rocha, ou até mesmo uma respiração, segundo Bueno (DAHLET, 2006, p.141-142). De qualquer forma, é sabido que, como diz Dahlet, “apesar do grande número de paráfrases concernentes à ação da vírgula — além de separar e/ou indicar, ela isola, assinala, mostra, marca, denota - , sua função é uma só: segmentar" (Ibid., p.142).

Assim sendo, podemos elencar três princípios de sua ocorrência, de acordo com o Code ortographique et grammatical de R. Thimonier (1970):

1) Adição, quando separa elementos de função gramatical equivalente: "era o terceiro olho, a terceira narina, a terceira orelha do meu mestre" (MABANCKOU, 2006, p.14); ${ }^{112}$

2) Subtração, quando os elementos podem ser eliminados, como aposto e adjetiva explicativa: "é que estou persuadido de que ele não era qualquer um, esse filho

\footnotetext{
${ }^{110}$ No original: “m'a plutôt appelé un soir et m'a dit 'tiens, demain, dès l'aube, à l'heure où blanchit la campagne, je veux que tu suives ce couillon de tireur de palme"”.

${ }^{111}$ No original: "et il se trouve que mon maître Kibandí possédait ce livre de Dieu dans lequel il y a plein d'histoires que les hommes sont forcés de croire au risque de ne pas mériter une place dans ce qu'ils appellent le Paradis, tu te doutes bien que j'ai mis mon nez dedans par curiosité puisque je pouvais lire couramment comme mon maître, il m'arrivait d'ailleurs de lire à sa place lorsqu'il était épuisé".

${ }^{112}$ No original: “j'étais le troisième oeil, la troisième narine, la troisième oreille de mon maître".
} 
de Deus, ele era um iniciado como o meu mestre" (Ibid., p.24); ${ }^{113}$ "então tentei um truque velho como o mundo, esperei a aparição do sol no sábado, quer dizer ontem, saí do meu esconderijo" (Ibid., p.30). ${ }^{114}$

3) Inversão, quando marca deslocamentos de segmentos da frase: "ela está bem longe, essa época na qual eu devia me separar do meu ambiente natural a fim de me aproximar daquele que era apenas uma criança" (Ibid., p.47). ${ }^{115}$

Esses três princípios de ocorrência aparecem, no livro, misturados, uma vez que a vírgula é o único sinal de pontuação. Assim, uma vírgula de adição é seguida por uma vírgula de subtração ou de inversão, e assim por diante. Isso faz com que o relato tenha um fluxo contínuo, e as pausas sejam feitas de outras formas, que não pela pontuação. Segundo Dahlet, "a vírgula põe em espera (em stand by) um ou vários segmentos, em razão do não fechamento de sentido" (DAHLET, 2006, p.152), ou seja, no romance, o uso desse sinal como única forma de pontuação deixa a narrativa em aberto, como se nenhum dos parágrafos tivesse um começo ou um fim determinados. Essa ideia é também reforçada pelo uso da minúscula no começo dos parágrafos.

A narrativa é interrompida apenas quando o narrador faz suas pausas para respirar, marcadas não apenas pelo discurso do narrador mas também pelos espaços em branco na página, conforme vimos. O fluxo de vírgulas, por fim, faz com que a pontuação se desloque para elementos lexicais e sintáticos, como as interjeições, os provérbios, as repetições estruturais, e o ritmo, então, é produzido por esses elementos.

\section{Oralidade na esfera microestrutural}

O uso recorrente de alguns elementos na esfera microestrutural é importante no romance pois também se relaciona à oralidade e à cultura congolesa: sabe-se que na literatura oral existem técnicas para a memorização das histórias, por exemplo no que

\footnotetext{
${ }^{113}$ No original: “c'est que je suis persuadé qu'il n'était pas n'importe qui, ce fils de Dieu, il était un initié comme mon maître".

${ }^{114}$ No original: “j’ai donc essayé un truc vieux comme le monde, j'ai attendu l'apparition du soleil le samedi, c'est-à-dire hier, je suis sorti de ma cache".

${ }^{115}$ No original: "qu'elle est bien loin, cette époque où je devais me séparer de mon milieu naturel afin de me rapprocher de celui qui n'était encore qu'un gamin".
} 
diz respeito às aliterações, assonâncias, harmonias vocálicas, repetições cantadas, ritmos de intensidade, de duração, de timbre e de volume do contador. É claro que transpor essas técnicas para um texto escrito seria uma tarefa impossível, já que não temos acesso ao corpo nem à voz do narrador/contador, porém Mabanckou, por meio das vírgulas e desses elementos sintáticos e lexicais, atravessa o escrito pelo ritmo da expressão oral. Destacaremos os seguintes elementos:

1) Repetições: tal qual fazemos no discurso oral, as repetições no livro acabam por enfatizar um argumento. Aparecem principalmente de três formas:

a) repetição de palavra (MABANCKOU, 2006, p.128-129):

gostaria que você guardasse ao menos da Mamãe Kibandí uma imagem de mulher corajosa, uma mulher que amava o seu filho, uma mulher humilde que viveu neste vilarejo, uma mulher que amou este vilarejo e que passava dias inteiros tecendo tapetes, uma mulher que talvez não encontrará o sono no outro mundo porque o meu mestre não cumpriu a sua palavra ${ }^{116}$

b) repetição da interjeição "hein" (Ibid., p.98):

'merda então, silêncio, eu disse, a senhora quer que eu a expulse daqui, hein, quer que eu lhe lance um exército de abelhas no pescoço, hein, o que é esta história, a senhora acha que eu sou quem, hein, ainda não compreendeu que este velho que está aqui e que a senhora acusa dessa desgraça não é aquele que comeu a sua filha, hein, vou ter que dizer quantas vezes, caramba, ${ }^{117}$

c) repetição estrutural: por exemplo, no trecho a seguir, em que vemos a estrutura "nome + profissão + característica + hein" se repetir várias vezes (Ibid., p.90-91):

e o que dizer de Mabialá o carteiro que ele suspeitava estar dando voltas ao redor de Mamãe Kibandí, hein, e de Lubandá o fabricante de tam-tam de quem ele reprovava o sucesso com as mulheres, hein, e de Senga o pedreiro que tinha recusado trabalhar para ele, hein, e de Dikamoná a corista das cerimônias fúnebres que não lhe dizia bom

\footnotetext{
${ }^{116}$ No original: "je voudrais que tu gardes au moin de Mama Kibandí une image de femme courageuse, une femme qui aimait son enfant, une femme humble qui a vécu dans ce village, une femme qui a aimé ce village et qui passait des journées entières à tisser ses nattes, une femme qui ne trouvera peut-être pas le sommeil dans l'autre monde parce que mon maître n'a pas tenu sa parole".

${ }^{117}$ No original: "merde alors, silence, j'ai dit, vous voulez que je vous chasse d'ici, hein, vous voulez que je vous lance une armée d'abeilles au cul, hein, c'est quoi cette histoire, vous me prenez pour qui, hein, vous n'avez pas encore compris que ce vieux qui est ici et que vous accusez de ce malheur n'est pas celui qui a mangé votre fille, hein, je vais vous le dire combien de fois, bordel".
} 
dia, ela que o tinha tratado de velho bruxo em público, hein, e de Lupialá a primeira enfermeira diplomada vinda de Mossaká ${ }^{118}$

E no seguinte trecho, em que temos a estrutura "(adjetivo) + substantivo + característica" (Ibid., p.41):

penso na pobre tartaruga e a sua carapaça rugosa, no elefante e a sua tromba pesada, no infeliz búfalo e os seus chifres ridículos, no imundo porco e o seu focinho que ele enfia na lama, na serpente desprovida de patas e que se move rastejando, no chimpanzé macho e os seus testículos que balançam como cabaças cheias de vinho de palma ${ }^{119}$

2) Acumulações ou enumerações: são menos comuns, mas aparecem normalmente em descrições referentes à savana: "sonhei também que me encontrava no meio de flamas que devastavam a savana inteira, semeavam o pânico até mesmo entre nossos inimigos eternos que são os leões, os leopardos, as hienas manchadas, os chacais, as onças, os tigres ou as panteras" (Ibid., p.36); ${ }^{120}$ ou em relação a sentimentos: "eu sei agora que o pensamento é algo essencial, é ele que inspira nos homens a tristeza, a piedade, o remorso, até a maldade ou a bondade" (Ibid., p.26). ${ }^{121}$

3) Interjeições: "hein”; “ah non”, presentes em muitas passagens do livro, são responsáveis também por pausar a narrativa, algumas vezes substituindo um sinal de pontuação - o "hein", por exemplo, é usado para substituir o ponto de interrogação, como podemos ver no exemplo supracitado sobre a repetição de interjeição.

4) Reestruturações semânticas: neologismos de forma e sentido, ou seja, palavras ou expressões que são usadas com um novo significado, ancorado na voz do povo. Por exemplo, a expressão "manger quelqu'un" [comer alguém], que nada tem a ver com canibalismo, deve ser entendida em seu sentido metafórico. Segundo pesquisa

\footnotetext{
${ }^{118}$ No original: "et qu'en était-il de Mabiala le facteur qu'il soupçonnait de tourner autour de Mama Kibandí, hein, et de Loubanda le frabricant de tam-tam à qui il reprochait son succès auprès des femmes, hein, et de Senga le briquetier qui avait refusé de travailler pour lui, hein, et de Dikamona la choriste des veillées mortuaires qui ne lui disait pas bonjour, elle qui l'avait traité de vieux sorcier en public, hein, et de Loupiala la première infirmière diplômée originaire de Mossaká".

119 No original: "je pense à la pauvre tortue et sa carapace rugueuse, à l'éléphant et sa trompe encombrante, au malheureux buffle et ses cornes ridicules, au crasseux cochon et son groin qu'il fourre dans la vase, au serpent dépourvu de pattes et qui se déplace par reptation, au chimpanzé mâle et ses testicules qui pendouillent comme des gourdes pleines de vin de palme".

${ }^{120}$ No original: "j'ai rêvé aussi que je me retrouvais au milieu des flammes qui ravageaient la brousse entière, semaient 1 apanique même chez nos éternels ennemis que sont les lions, les léopards, les hyènes tachetées, les chacals, les guépards, les tigres ou les panthères".

${ }^{121}$ No original: "je sais à present que la pensée est quelque chose d'essentiel, c'est elle qui inspire aux hommes le chagrin, la pitié, les remords, voire la méchanceté ou la bonté".
} 
feita por Bintou, "Na África ao sul do Saara, quando dizemos manger quelqu'un, manger l'âme de quelqu'un ou manger le sang de quelqu'un, isso quer dizer 'destruir o princípio de vida, enfeitiçar alguém, se tornar mestre dele, destruí-lo por meio de bruxaria"” (2014, p. 278). ${ }^{122}$ Na história, lemos (MABANCKOU, 2006, p.93, grifos do autor):

Papai Kibandí escutou dessa vez a palavra "bruxo" assim que colocou os pés para fora de casa, o tratavam de "rato pestífero", não lhe davam tempo de se explicar, ele teria querido discutir isso com a sua irmã, lhe demonstrar que podia acusá-lo de tudo menos de ter comido a sua sobrinha, e quando eu digo comido, é preciso compreender, meu querido Baobá, que se trata de pôr fim aos dias de um indivíduo por meios imperceptíveis para aqueles que negam a existência de um mundo paralelo ${ }^{123}$

Ou a expressão "autre lui-même" [outro ele mesmo], que está relacionada à identidade e à lenda dos duplos: “você não viu nada, eu sou eu, e aquele que está deitado ao lado da sua mãe, pois bem, também sou eu, eu posso ser ao mesmo tempo eu mesmo e o outro eu mesmo que dorme, você entenderá logo" (Ibid., p.80, grifos do autor). ${ }^{124}$

Ou ainda a expressão "avoir quelque chose" [ter alguma coisa], utilizada sempre em itálico, o que reforça ainda mais o deslocamento de sentido e colabora ao efeito de surpresa provocado no leitor estrangeiro: "Mossaká inteira dizia agora em uníssono que Papai Kibandí tinha alguma coisa” (Ibid., p.89, grifos do autor). ${ }^{125}$

5) Empréstimos linguísticos vindos de línguas autóctones: normalmente não são compreensíveis para o público francês, porém dão sonoridade e ritmo ao texto, além de evidenciarem a ancoragem geolinguística-cultural e o multilinguísmo das personagens. Esses empréstimos são, no livro, vistos nos topônimos, como Sêkêpembê e Lubulá; nos antropônimos, como Kibandí, Tembê-Essuká, Mundjulá, para citar alguns; e em

\footnotetext{
${ }^{122}$ No original: "En Afrique au Sud du Sahara, lorsqu'on dit manger quelqu'un, manger l'âme de quelqu'un, ou manger le sang de quelqu'un, cela veut dire "détruire le principe de vie, envoûter quelqu'un, se rendre maître de lui, le détruire par sorcellerie' (IFA, 1988 (1983), p. 230)".

${ }^{123}$ No original: "Papa Kibandí entendait cette fois-ci le mot 'sorcier' dès qu'il mettait les pieds hors de sa case, on le traitait de 'rat pestiféré', on ne lui laissait pas le temps de s'expliquer, il aurait voulu en discuter avec sa soeur, lui démontrer qu'on pouvait l'accuser de tout sauf d'avoir mangé sa nièce, et quand je dis mangé, il faut comprendre, mon cher Baobab, qu'il s'agit de mettre fin aux jours d'un individu par des moyens imperceptibles pour ceux qui nient l'existence d'un monde parallèle".

${ }^{124}$ No original: "tu n'as rien vu, je suis moi, et celui qui est couché à côté de ta mère, eh bien, c'est aussi moi, je peux être à la fois moi-même et l'autre moi-même qui est couché, tu le comprendras bientôt".

${ }_{125}$ No original: "tout Mossaká rapportait maintenant d'une seule voix que Papa Kibandí possédait quelque chose".
} 
algumas palavras isoladas, como batêkê, mwenguê, mayamvumbí ou em frases como: "é incapaz até mesmo de subir numa mangueira, tipos como você são estragados, maniongí, ngêbês, ngubás ya ko polá” (Ibid., p.172). ${ }^{126,127}$

6) Provérbios: vimos que os provérbios apresentam características macroestruturais, relacionadas à função que têm na narrativa e aos aspectos culturais concernentes à literatura oral de expressão francesa. Porém, podemos também observar na esfera micro a estrutura gramatical do provérbio, que facilita sua identificação no discurso. $^{128}$

Um dos recursos estruturais mais recorrentes do provérbio é seu ritmo binário, conforme explica Chevrier (1986), que pode reforçar-se pelos efeitos de paralelismo, simetria ou oposição. Além disso, outros elementos rítmicos seriam a rima, a assonância ou aliteração e os pares semânticos "em relação de semelhança, oposição, dependência" (LARANJEIRA, 1993, p.67). A título de exemplo poderíamos citar "quand le sage montre la lune, l'imbécile regarde toujours le doigt" [quando o sábio mostra a lua, o imbecil olha sempre para o dedo] (MABANCKOU, 2006, p.49-50), que apresenta estrutura binária marcada pelo par em oposição sage/imbécile.

Cauvin (1981) observa que vários provérbios apresentam uma única proposição, um sujeito formado por mais de uma palavra, um verbo e uma negativa. Já Leguy (2004) acrescenta, em relação ao corpus analisado por ela, que essa proposição é muitas vezes causal e seguida de uma consequência de implicação lógica. Outras vezes é utilizada a fórmula “c'est...” [“É...”] ou “ce n’est pas...” [“não é...”] para dar valor universal ao enunciado.

Por exemplo, na página 26, o narrador começa a contar como era sua vida assim que terminava uma missão imposta por seu mestre: ele ia para a floresta, meditava, descansava, observava os outros animais. Narra que foi aí que aprendeu a pensar sempre na melhor solução para os obstáculos impostos pela vida, e então diz que apesar dos homens já nascerem predispostos à inteligência, não são todos que a desenvolvem, pois é preciso cultivá-la, regá-la a fim de que ela se desenvolva. O porco-espinho faz

\footnotetext{
${ }^{126}$ No original: "tu es incapable de grimper même à un manguier, des types comme toi sont des foireux, des maniongi, des ngébés, des ngoubas ya ko pola".

${ }^{127}$ Os comentários sobre a tradução desse léxico serão feitos no Capítulo 3.

${ }^{128}$ Aqui, também, parte da análise já foi publicada no artigo "A tradução de provérbios em Alain Mabanckou", Revista Non Plus, n.7, p.54-66, 2015.
} 
referência nesse momento a fábulas de La Fontaine, como já vimos, para ilustrar a imbecilidade de certos humanos, e termina por dizer: "esses humanos viverão na escuridão, sua única consolação será a de serem homens, o velho porco-espinho que nos governava teria dito a respeito deles "são todos cretinos, serem homens é o último argumento deles, ora não é porque a mosca voa que isso fará dela um pássaro" (MABANCKOU, 2006, p.26, grifos do autor). ${ }^{129}$

Além de do uso das aspas, do itálico, e da fórmula introdutória "o velho porcoespinho que nos governava teria dito a respeito deles" [le vieux porc-épic qui nous gouvernait aurait lancé à leur égard], nesse caso a citação não é apenas do provérbio, mas de uma oração inteira que teria proferido o velho governante. O provérbio aparece na segunda parte da fala do animal, de forma a reforçar o que foi dito na primeira parte, como se ele precisasse embasar sua opinião com uma frase de efeito. Para isso a fórmula inicial “ce n'est pas” [não é] é eficiente para enfatizar a verdade universal, dando maior credibilidade ao dito e às palavras proferidas pela personagem. Também podemos observar aqui a relação entre a parte (mosca [mouche]) e o todo (pássaro [oiseau]), o que caracteriza a figura de linguagem da metonímia. O significado metafórico é atingido por meio do deslocamento de sentido por comparação entre homem e animal, quer dizer, o animal é usado nele para fazer referência ao homem e ao fato de que as aparências enganam. No romance, esse provérbio é usado para reforçar a crítica que o narrador faz aos humanos que, apesar de possuírem a aptidão de pensar, muitas vezes não são inteligentes ou não fazem bom uso dessa aptidão.

Podemos concluir, a partir desse panorama em que destacamos alguns dos aspectos estruturais do livro, que tanto as características macroestruturais, relacionadas à forma com que a narrativa é construída e às referências culturais, quanto as microestruturais, relacionadas à sintaxe e ao léxico escolhido, são importantes nesse romance para aproximar o leitor do universo oral da contação de histórias, que é central na construção da narrativa sem deixar, no entanto, a escrita de Mabanckou informal. O autor mescla elementos orais da cultura congolesa, mas domina inteiramente a arte narrativa e as formas típicas do romance, tecendo uma obra plural, com diversas

\footnotetext{
${ }^{129}$ No original: "ces humains vivront dans les ténèbres, leur seule consolation sera d'être des hommes, le vieux porc-épic qui nous gouvernait aurait lancé à leur égard "ce sont tous des crétins, être des hommes est leur dernier argument, or ce n'est pas parce que la mouche vole que cela fera d'elle un oiseau"'.
} 
interferências e referências vindas das diferentes culturas com as quais conviveu, conforme vimos ser típico de sua maneira de escrever e de sua visão de mundo.

A questão que se coloca, a seguir, é, portanto, como transmitir esse universo plural, com elementos vindos de diferentes culturas e línguas, na tradução para o português? Que estratégia adotar? 


\section{Capítulo 3}

\section{Espinhos da tradução}


O processo tradutório é um trabalho de relação com o Outro. Buscar entender que as palavras e as frases refletem escolhas culturais e ideológicas do autor é necessário e acaba por evidenciar dissonâncias entre os dois sistemas linguísticos em questão, no caso o francês e o português, e demanda do tradutor um olhar atento para o texto. Neste capítulo, portanto, faremos uma reflexão sobre o processo tradutório e nossas escolhas para a obra Mémoires de porc-épic, procurando pôr em relação a alteridade do texto de partida e sua passagem para o código de chegada.

\section{Projeto tradutório}

Antes de mais nada, é fundamental salientar que consideramos a tradução uma interpretação do texto original, ou seja, entendemos que o sentido de um texto não é fixo, e sim construído pelo leitor/tradutor. Por consequência, o tradutor não é mero transmissor da mensagem original, atuando como sujeito ativo no discurso. Segundo Francis Aubert (1994, p.80):

Será com base na dinâmica das relações imagéticas e dentro dos limites do conjunto de mensagens efetivamente depreendidas que o tradutor, longe de ser um médium passivo para a manifestação do autor e do texto de partida, terá de tomar decisões nos mais diversos níveis: comunicativo, linguístico, técnico. É, portanto e inevitavelmente, agente, elemento ativo, produtor de texto, de discurso.

Como bem observa Susan Bassnett, para fazer a interpretação do texto original — e em seguida sua tradução — o tradutor deve levar em conta "a estrutura global da obra e sua relação com o tempo e o lugar em que foi produzida" (2003, p. 135). ${ }^{130} \mathrm{O}$ conhecimento extralinguístico, cultural, histórico e contextual que o tradutor possui é essencial ao longo do processo, mas não necessariamente aparecerá de maneira explícita no texto traduzido. Assim como Aubert, Bassnett argumenta na mesma direção quando diz que (Ibid., p. 135-136):

primeiro o tradutor lê/traduz na língua de partida e, depois, através de um processo adicional de decodificação, traduz o texto para a língua

\footnotetext{
${ }^{130}$ Tradução de Vivina de Campos Figueiredo.
} 
alvo. Ao fazê-lo, o tradutor vai mais longe do que um simples leitor do texto original, pois aborda o texto a partir de mais de um conjunto de sistemas. Parece, portanto, descabido argumentar que a tarefa do tradutor é traduzir, mas não interpretar, como se se tratasse de dois exercícios separados. A tradução interlinguística há-de reflectir seguramente a interpretação criativa que o tradutor faz do texto original.

Essa leitura interpretativa foi feita nos capítulos 1 e 2, nos quais nos aprofundamos na visão de mundo de Mabanckou, nas características de sua obra de maneira geral e nas dimensões específicas do romance Mémoires de porc-épic. Dessa forma, ao interpretar o texto de partida, o tradutor se mostra como sujeito enunciador e produtor de sentidos, evidenciando que o processo tradutório vai além do simples conhecimento linguístico, abarcando também o processo de transferência cultural, que passou a ser reconhecido apenas em meados de 1970, quando o parâmetro para se avaliar a tradução deixou de ser o texto de partida e passou a ser "o complexo da recepção" (AZENHA, 2010, p.40), processo conhecido como "virada cultural".

A partir dessa época, então, se deslocou a noção de tradução centrada na língua para a de tradução ligada também à cultura, entendida aqui de forma abrangente, relacionada aos elementos da comunicação e da linguagem. A transferência cultural, assim, leva em consideração os recursos linguísticos diferentes entre a língua-cultura de partida e a de chegada e suas possíveis adaptações, mas também considera o propósito editorial na cultura receptora. Fala-se, por conseguinte, nos chamados marcadores culturais, associados às características de um universo linguístico-cultural diferente daquele para o qual se traduz, cabendo ao tradutor, na sua leitura interpretativa, enxergá-los e recontextualizá-los (ou não) no texto de chegada.

Acreditamos ter deixado claro nos capítulos precedentes que, durante a nossa leitura da obra $M P E$, encontramos marcadores referentes não apenas ao Congo, mas a diversas culturas e, principalmente, à oralidade própria da tradição africana de contação de histórias. Com o intuito de resgatar essas pinceladas culturais dadas por Mabanckou, buscou-se, na tradução, construir uma linguagem que recrie a ambientação da obra, e discutiremos, nos comentários a seguir, algumas soluções encontradas.

Partir do pressuposto de que toda tradução é uma interpretação do original é assumir que o tradutor não é invisível e, logo, que ele não se apaga do texto traduzido. Percebemos que ao voltarmos nosso olhar ao Outro, tentando captar marcas culturais e 
nuances do original, suas particularidades e estranhezas, nos aproximamos da abordagem tradutória de viés não etnocêntrico proposta por alguns teóricos importantes.

Em 1813 o filósofo e teólogo alemão Schleiermacher escreve um artigo (traduzido por Celso Braida e publicado em 2007 pela revista Princípios, de Natal) no qual expõe sua reflexão sobre a tradução, dizendo que existem duas possibilidades: "ou bem o tradutor deixa o escritor o mais tranquilo possível e faz com que o leitor vá a seu encontro, ou bem deixa o mais tranquilo possível o leitor e faz com que o escritor vá a seu encontro" (SCHLEIERMACHER, 2007, p.242). ${ }^{131}$ Na primeira hipótese teríamos a tradução chamada de não etnocêntrica, que se oporia à segunda hipótese, etnocêntrica. As traduções do segundo tipo procuram eliminar todo tipo de elemento lexical ou sintático "estranho" à língua para a qual se traduz, e o tradutor tenta transmitir ao leitor a sensação de que aquela obra foi originalmente escrita em sua língua. Para Schleiermacher esse tipo de tradução é inviável, pois ninguém está ligado a sua língua apenas mecanicamente, estando a língua sempre relacionada à cultura e à identidade de um povo, e portanto seria impossível tentar transmitir ao leitor a sensação de que aquela obra foi originalmente escrita em sua língua. Resta, para ele, o primeiro tipo de tradução, a não etnocêntrica, na qual o tradutor tenta transmitir ao leitor o "brilho de novidade" do texto original (Ibid., p.247), deixando claro que aquele autor viveu e escreveu em outra língua e cultura. Para o filósofo, esse tipo de tradução é necessária e útil, apesar de muitas vezes ser tênue a diferença entre um texto que transmite ao leitor a sensação de estar diante de uma obra estrangeira e um texto que se apresenta demasiadamente exótico, podendo até mesmo se mostrar incompreensível na língua de chegada.

Antoine Berman (2007) argumenta na mesma direção que Schleiermacher, opondo-se à tradução que aclimata o texto original de tal maneira que pareça fruto da própria língua de chegada, que é vista como superior. Esse foi o caso, nos séculos XVII e XVIII, das "belas infiéis" na França, que procuravam embelezar e naturalizar o texto original. Nessa época, é como se a tradução fosse, sempre, uma traição do texto original, não sendo capaz de transmitir exatamente o que ele transmitira. Como se a língua fosse ameaçada pelo processo de tradução.

\footnotetext{
${ }^{131}$ Parte desta análise já foi publicada no artigo de minha autoria intitulado "A tradução de provérbios em Alain Mabanckou", Revista Non Plus, n.7, 2015, p.54-66.
} 
É interessante lembrarmos aqui do pensamento de Édouard Glissant sobre a relação entre os povos, que pode ser transposto para o âmbito tradutório. Antigamente, na Ilíada ou no Antigo Testamento, os povos eram vistos combatendo uns aos outros com o intuito de conquistar mais territórios. Não se relacionavam entre si, apenas se focavam em seus próprios interesses. O filósofo martiniquense entende que, na configuração histórica atual, é preciso levar em conta a totalidade-mundo, ou seja, considerar a existência de outros povos e línguas e relacionar-se com eles. O desafio seria saber "como ser si mesmo sem fechar-se ao Outro; e como consentir na existência do outro, na existência de todos os outros, sem renunciar a si mesmo?" (2005, p.46). ${ }^{132}$ Acreditamos que o mesmo desafio se aplica à tradução, no sentido de que falam Schleiermacher e Berman: como traduzir para a sua língua (ser si mesmo) sem ofuscar a alteridade do texto original (a existência o outro), e como fazer isso sem, no entanto, deixar a tradução incompreensível na língua de chegada (renunciar a si mesmo).

A transposição desse pensamento de Glissant para a esfera tradutória não é feita apenas por nós, ele mesmo teoriza sobre a intersecção da tradução com sua teoria sobre o imaginário das línguas, dizendo, em entrevista, que:

Eu não penso que o ser da língua hoje em dia esteja nem exaltado nem ameaçado pela tradução, pois esquecemos que o que nos interessa hoje nas línguas é o ser da língua, é claro, mas é também a relação da língua, quer dizer, a relação da língua com todas as línguas possíveis. ${ }^{133}$

Glissant entende que a tradução é uma arte primordial, que busca relacionar toda língua com toda língua. A noção antiga que almejava a equivalência exata entre a tradução e o original, sendo a tradução sempre inferior ao texto de partida, cede lugar à visão na qual a tradução é um texto autônomo, um trabalho de criação artística em que o tradutor tenta "descobrir os esquemas de funcionamento da relação de toda língua com toda língua". 134

\footnotetext{
${ }_{132}^{132}$ Tradução de Enilce. Albergaria Rocha.

${ }^{133}$ No original: "Je ne crois pas que l'être de la langue aujourd'hui soit ni exalté ni menacé par la traduction parce qu'on oublie que ce qui nous intéresse aujourd'hui dans les langues c'est l'être de la langue, bien sûr, mais c'est aussi la relation de la langue, c'est-à-dire la relation de la langue à toutes les langues possibles". Acessível em: < http://mondesfrancophones.com/dossiers/edouard-glissant/traduirela-relation-des-langues-un-entretien-avec-edouard-glissant/ > .

${ }^{134}$ No original: "découvrir les schémas de fonctionnement de la relation de toute langue à toute langue" (Idem).
} 
Isso posto, pensamos que as escolhas e decisões feitas ao longo da tradução procuram "evitar tanto a apropriação etnocêntrica que reduz a alteridade do texto traduzido, quanto a transcrição literal, que desafia a estrutura da língua de chegada" (COMBE, 2010, p.133), ${ }^{135}$ citação esta que está completamente de acordo com a fala supracitada de Glissant sobre não renunciar a si mesmo e, ao mesmo tempo, não fecharse ao Outro. Dessa forma, entende-se que uma visão etnocêntrica da tradução é como uma raiz única, que se baseia apenas em sua estrutura e não se estende, se aproxima e se relaciona com o entorno. Ao contrário, uma visão não etnocêntrica da tradução seria como um rizoma, pois faria ecoar na língua de chegada elementos da língua de partida, produzindo um texto heterogêneo. O texto traduzido, apesar de escrito em uma única língua, estaria em relação com o imaginário das línguas proposto por Glissant, levando em conta a alteridade do texto original. Em vista disso, a relação entre a tradução e o original não apresentaria mais a dicotomia traição-fidelidade, e o tradutor tenderia a enxergar a língua com relatividade, não como um absoluto linguístico enraizado.

Assim, do mesmo modo que discutimos a identidade se construindo e reconstruindo a partir das conexões com o Outro, em forma de rizoma, é interessante pensar a tradução como um processo de construção e reconstrução de sentidos a partir da relação da língua de chegada com a língua de origem e seus desdobramentos — no caso de $M P E$, a presença das línguas africanas e de outras línguas por meio da intertextualidade —, também de forma rizomática. O próprio Glissant relaciona tradução e identidade ao dizer que:

A tradução, prática do encontro no qual negociamos sem cessar sua
relação com o Outro, oferece uma perspectiva promissora para
abordar a questão da identidade. O texto traduzido é, na verdade, o
próprio lugar desse encontro, um lugar bem perigoso, pois é fácil tanto
se perder nele (por traduções literais inconscientes, contrassensos
despercebidos, inaptidões linguísticas) quanto perder de vista o Outro
por meio de práticas mais ou menos conscientes de dominação ego ou
etnocêntrica. ${ }^{136}$

\footnotetext{
${ }^{135}$ No original: "éviter aussi bien l'appropriation ethnocentrique qui réduit l'altérité du texte traduit, que la transcription littérale, qui défie la structure de la langue d'arrivée".

${ }^{136}$ No original: "la traduction, pratique de la rencontre où on négocie sans cesse son rapport avec l'Autre, offre une perspective prometteuse pour aborder la question de l'identité. Le texte traduit est en effet le lieu même de cette rencontre, un lieu bien hasardeux car il est aussi facile de s'y perdre (par des calques inconscients, des contre-sens inaperçus, des maladresses linguistiques) que de perdre de vue l'Autre par des pratiques plus ou moins conscientes de domination ego- ou ethnocentrique". Acessível em:
} 
Sendo a tradução uma constante busca por uma relação com a alteridade, e sendo essa alteridade entendida como rizomática, ou seja, nunca binária, mas sim múltipla, procuramos encontrar soluções linguísticas que não pretendem ser únicas, redutoras, perfeitas, mas antes pensadas dentro da lógica híbrida de relação com o Outro.

Entendemos que o próprio processo de escrita de um texto é, também, uma tradução, tanto do pensamento para o papel como, no caso dos autores de expressão francesa, do pensamento em língua autóctone para o papel em língua francesa. Conforme vimos, a polifonia presente em MPE diz respeito à relação de Mabanckou com as diversas línguas e literaturas às quais teve acesso, de forma que sua escrita em francês transmite o "ritmo congolês" de seu pensamento. Assim sendo, pensar a tradução como um processo de viés não etnocêntrico nos parece interessante na medida em que, partindo dessa abordagem, pode-se transmitir ao leitor brasileiro o heterolinguismo que o leitor francês também encontra no texto original, uma vez que não conhece as línguas africanas. Dessa maneira, ao tentar aproximar o leitor do escritor, como diz Schleiermacher, é possível remeter o público às particularidades do texto original que, segundo nossa leitura interpretativa, são marcas culturais centrais no romance. Além disso, adotar essa estratégia evidencia a presença do tradutor no texto traduzido, ao invés de apagá-lo do texto a todo custo, o que nos leva ao item seguinte, sobre as notas de tradução.

\section{Notas de tradução}

Ao falar sobre a invisibilidade ou não do tradutor no texto traduzido, fala-se, resumidamente, sobre duas visões distintas sobre o processo tradutório. De um lado, existe a visão tradicional, na qual o tradutor é mero transmissor da mensagem do autor e tenta se apagar ao máximo da tradução, enquanto, do outro lado, temos a visão “contestadora”, nas palavras de Mittmann (2003), na qual o tradutor é visto como sujeito enunciador e criador, conforme vimos no item anterior ser a visão de Aubert e

http://mondesfrancophones.com/dossiers/edouard-glissant/traduire-la-relation-des-langues-un-entretienavec-edouard-glissant/ 
Bassnett. Para os adeptos da visão tradicional, o recurso das notas de tradução é usado como auxílio à compreensão do texto, entendendo-se que o sentido do texto original já está dado e que o tradutor é responsável apenas por repassá-lo ao leitor da língua de chegada. Contrário a isso, os defensores da visão contestadora pensam que as notas de tradução são o lugar em que o tradutor analisa o próprio processo da tradução.

Ora, acreditamos ter deixado claro até aqui que somos adeptos da visão contestadora, já que se trata de aproximar o texto traduzido de seu autor, atentando para sua estranheza original, o que por sua vez revela a tradução como sendo de fato uma tradução e, por conseguinte, revela também o tradutor como sujeito enunciador, e não mero transmissor de uma mensagem.

Isso posto, criticar as notas por darem visibilidade ao tradutor nos parece descabido. Como diz Sardin (2007, p.2): “O tradutor não se apaga nunca atrás do autor, mas, ao contrário, imprime no texto sua subjetividade e pressupostos do contexto sociocultural no qual ele evolui". ${ }^{137}$ Mittmann, argumentando na mesma linha que Sardin, diz que as notas de tradução fazem parte do processo tradutório como um “discurso de extensão" (2003, p.129), um discurso que é produzido fora do texto, mas em diálogo com ele, revelando a "materialidade do discurso do tradutor durante e sobre o processo tradutório" (Ibid., p.131).

Esclarecendo que as notas são parte do processo e do discurso do tradutor, a próxima questão é estabelecer que tipo de notas produzir e de que maneira apresentá-las ao leitor. Por se tratar de um romance extenso, achamos descabido sobrecarregar o texto com notas de rodapé dos mais variados tipos, o que se tornaria cansativo e quiçá enfadonho. Por consequência, as 8 notas de rodapé propostas são bastante pontuais, concernentes a explicações sobre fraseologismos ou léxico africano (ver Apêndice A com as notas de rodapé). Apesar de serem notas explicativas, situacionais ou culturais, que poderiam ser encaradas como limitadoras do sentido depreendido pelo leitor, fazendo parte da visão tradicional acima refutada, o intuito não é, com elas, controlar o sentido do texto, mas dar a ver nossa interpretação dessa mensagem, mostrando como o tradutor participa do processo criativo do texto. Como bem esclarece Mittmann, "a tradução é resultado de uma interpretação particular, que se dá em condições específicas

\footnotetext{
${ }^{137}$ No original: "le traducteur ne s'efface jamais derrière l'auteur, mais il imprime au contraire le texte de sa subjectivité et des pressuposés du contexte socioculturel dans lequel il évolue".
} 
e se dirige para um público diferente daquele imaginado pelo autor. Todo esse processo se manifesta nas N.T.” (Ibid., p.120).

À parte essas notas pontuais de rodapé, produzidas e pensadas especialmente no caso da tradução ser publicada comercialmente, há anotações que antecedem a tradução, nas quais são aprofundadas questões culturais e situacionais já vistas nos capítulos anteriores, mas que são retomadas agora sob o ângulo tradutório, revelando não somente o percurso percorrido, mas também angústias, dificuldades, dúvidas do tradutor. Essas anotações são um espaço de maior subjetividade do que as primeiras, de rodapé. Segundo Mittmann (Ibid., p.159):

ao contrário do que tem prescrito a concepção tradicional, temos encontrado, por vezes, nas notas, uma não-saturação, uma indeterminação do sentido, quando a N.T. não traz a definição como verdade absoluta. $\mathrm{O}$ tradutor pode apresentar dúvidas. A expressão da incerteza, portanto, é outra forma de manifestação do embate do tradutor com relação ao processo tradutório.

No âmbito acadêmico, entendemos que as anotações poderão servir aos estudiosos e teóricos da tradução que se interessem pelo processo tradutório desse livro, além de servirem a mim, como tradutora, ao longo do processo e após sua conclusão, como forma de ajudar a pensar nas possíveis soluções para as questões levantadas. Em outras palavras, é pensando sobre o processo que o processo se dá. Já no âmbito comercial e editorial, as notas podem ser transformadas em paratextos à tradução, por exemplo, sob a forma de prefácio ou de nota do tradutor, como maneira de ambientar o leitor e trazer-lhe novos elementos e hipóteses para ampliar sua leitura.

Enfatizamos que as anotações não devem ser encaradas como limitadoras ou controladoras do sentido da leitura, como se servissem para abrir os olhos do leitor para o "real" sentido daquele texto. Muito pelo contrário, as notas são vistas como uma das leituras possíveis, feitas para dividir com o leitor angústias e dificuldades encontradas pelo caminho, no sentido de que fala Ana Cristina Cesar em "O conto Bliss anotado". Nesse ensaio, ela explica que as notas, inicialmente específicas, acabaram por ganhar outra dimensão, muito maior do que a própria tradução, abarcando "os movimentos da mão e da mente do tradutor" (1999, p.286). A autora complementa (Ibid., p.292, grifo nosso): 
Uma tradução anotada pode ser encarada como tarefa fundamentalmente técnica. No entanto, se nos indagarmos sobre as razões que levam à concentração de notas em determinados momentos da história, concluiremos que o comentário técnico é inconscientemente conduzido por pontos literários centrífugos, isto é, pelo conteúdo. O tradutor se vê mais envolvido (pessoal e profissionalmente) pelos trechos em que a história se intensifica, sentindo, assim, maior necessidade de explicá-la.

Concordando com a citação de Ana Cristina Cesar, adicionamos ainda o fato de que o conteúdo, no caso de $M P E$ de Mabanckou, está intimamente ligado à tradição oral de contação de histórias, que por sua vez remete ao "ritmo congolês" evocado pelo autor. Este, por fim, se revela tanto na semântica quanto na sintaxe da narrativa. Isso nos mostra que os elementos analisados até aqui estão interligados e são responsáveis, em conjunto, pelo que denominamos ser o ritmo da prosa e, consequentemente, pela produção das notas de tradução.

Com o intuito de melhor orientar a leitura dessas notas, as dividiremos em dois grandes grupos: as anotações semânticas e as sintáticas, sendo as primeiras mais culturais e baseadas em nossa leitura pessoal, e as últimas mais preocupadas com questões gramaticais e linguísticas. Dentro de cada um dos grupos, serão destacados alguns elementos considerados primordiais na estrutura narrativa do romance.

Mesmo que este não seja um tema central neste trabalho, é importante, ainda que em linhas gerais, explicitar o que chamamos aqui de ritmo da prosa. ${ }^{138}$ Assim como a poesia tem o seu ritmo marcado pelos versos, rimas e imagens, o texto em prosa tem sua organização própria que, de outra forma, também diz respeito ao ritmo da narrativa. Benveniste diz que é a "maneira particular de fluir" de cada texto (1995, p.368), "as 'disposições' ou 'configurações' sem fixidez [...], resultantes de um arranjo sempre sujeito à mudança" (Idem). ${ }^{139}$ Mesmo não sendo tão evidente quanto na poesia, essa maneira de fluir pode ser percebida no texto em prosa em alguns elementos, tais como: o começo do texto, a pontuação, a sintaxe, a estrutura das frases, os paralelismos, os temas principais. Podemos pensar o ritmo na prosa como "uma rede de orientação e de

\footnotetext{
${ }^{138}$ A análise feita aqui já foi parcialmente publicada no artigo de minha autoria "Traduzindo o ritmo e a oralidade em Alain Mabanckou”, Cultura e Tradução, João Pessoa, v.3, n.1, 2014, p.260-270.

${ }^{139}$ Tradução de Maria da Glória Novak e Maria Luisa Neri.
} 
densificação do discurso", ${ }^{140}$ como uma estrutura responsável pela dinâmica de produção narrativa e poética (BORDAS, 2012, p.3).

Se temos passagens bastante rítmicas no texto em prosa, temos também outras opostas a estas, quer dizer, intervalos rítmicos curtos ou longos, que podem ser pensados como momentos de silêncio, de pausas rítmicas, de pulsações que aparecem e desaparecem. Em MPE, esses silêncios aparecem na fala do narrador, ou seja, no próprio conteúdo, mas também na estrutura visual do livro, marcados pelos espaços em branco e pelas quebras nas páginas. Segundo Bordas, é interessante considerar o silêncio como parte do discurso (Idem):

Nós teríamos tudo a ganhar em aprender a não pensar o silêncio como falha, menos ainda a vivê-lo como uma ameaça de afasia, mas a considerá-lo como discurso ativo, que tem sua sintaxe, ainda que não tenha uma gramática e um léxico. Uma sintaxe concretizada nas pulsações rítmicas de seu aparecimento/desaparecimento, por exemplo. ${ }^{141}$

Voltando à citação de Ana Cristina Cesar, se as anotações técnicas (sintáticas) se intensificam em passagens em que o conteúdo é mais marcante, a autora complementa, em outro ensaio, que é o conteúdo, junto com a sintaxe, que determina o ritmo da prosa. Diz: “em prosa o ritmo não é mensurável e depende diretamente da sintaxe e do conteúdo; pode, então, acontecer que a consciência do ritmo que o texto nos transmitiu se evapore, capitulando perante o interesse pela trama do livro" (CESAR, 1999, p.366, grifo nosso). Percebemos, portanto, que nossas anotações, tanto sintáticas quanto semânticas, procuram estabelecer uma conexão com o ritmo do texto de partida, visto no Capítulo 2.

Não se pode deixar de ressaltar, também, que a tradução do ritmo depende da interpretação rítmica que o tradutor faz do texto, e foi isso que tentamos observar até o momento, ao pensarmos nas esferas macro e microestruturais do romance. Essas esferas buscam mostrar o que Ana Cristina Cesar chama de "padrões obsessivos do texto" (Ibid., p.367-8), que, na análise dela sobre a tradução de Machado de Assis, poderiam ser: a interrupção do fluxo narrativo por meio da intercalação de um conceito marcante

\footnotetext{
${ }^{140}$ No original: "une grille d'orientation et de densification du discours".

${ }^{141}$ No original: "Nous aurions tout à gagner à apprendre à ne pas penser le silence par défaut, moins encore à le vivre comme une menace d'aphasie, mais à l'envisager comme un discours actif, qui a sa syntaxe, à defaut d'avoir une grammaire et un lexique. Une syntaxe concrétisée dans les pulsations rythmiques de son apparition/disparition, par exemple".
} 
ou de uma asserção curta, que resume e corta a ideia; pausas e expressões intercaladas que dão maior tensão à determinada passagem, atrasando a conclusão de uma ideia, dando origem a mais "pontos de respiração" no texto; o uso do vocativo no início das frases, dando maior tensão à passagem, ou no fïm da frase, dando menor tensão; o uso frequente de conjunções, transmitindo uma sensação de rapidez e de insistência na enumeração; o uso dos conectivos no paralelismo (Ibid., p.371-3). Todos esses elementos mostram as oscilações entre narrar e não narrar, a alternância de trama e digressão, e dependem tanto da sintaxe quanto do léxico.

Ao analisar um texto literário atentando para as relações sintáticas, lexicais, rítmicas do próprio discurso, pode-se então observar "como se dá a significação de um texto, e como ela se dá cada vez de uma forma diferente, específica" (DESSONS, MESCHONNIC, 1998, p.7; grifo dos autores). ${ }^{142}$ Logo, ao longo deste trabalho, procuramos mostrar "padrões obsessivos" encontrados em MPE, e as notas aqui propostas giram em torno dessas descobertas. Todos os elementos comentados contribuem para a organização do discurso do romance — seu ritmo - alguns de forma a acelerar e dar tensão à narrativa, outros responsáveis por pausas, respiros ou silêncios.

\subsection{Anotações semânticas}

Os comentários que consideramos próprios a este bloco dizem respeito, notadamente, a dois elementos primordiais no romance, a saber: o processo de transferência cultural e os registros de língua. Isso não quer dizer, no entanto, que esses mesmos elementos não apareçam também nos comentários sintáticos, que veremos adiante.

O primeiro aspecto que salta aos olhos em relação à transferência cultural é a tradução dos fraseologismos, presentes ao longo de todo o romance com forte valor simbólico, cultural. Entendemos que os fraseologismos, ou unidades fraseológicas, são lexias complexas ou, nas palavras de Corpas Pastor, "unidades léxicas, formadas por mais de duas palavras gráficas em seu limite inferior cujo limite superior se situa no

\footnotetext{
${ }^{142}$ No original: "comment se fait la signification d'un texte, et comment elle se fait chaque foit différemment, spécifiquement".
} 
nível da oração composta" (CORPAS PASTOR, 1997, p.20 apud SILVA, 2006, p.12), ${ }^{143}$ e que essa combinação de palavras apresenta características próprias que a diferenciam de outras unidades léxicas, tais como a frequência, a institucionalização, a fixação, a idiomaticidade, a variação e a gradação (SILVA, 2006, p.15). As unidades fraseológicas podem ainda ser subdivididas em outras denominações como locuções fraseológicas, colocações, idiomatismos, frases feitas etc., cada uma com suas especificidades e graus de fixação e idiomaticidade, e é importante ressaltar que não iremos nos aprofundar nessa terminologia e classificação. Nosso intuito não é analisar o grau de idiomaticidade, a classificação ou a nomenclatura das expressões encontradas, mas discutir quais são os desdobramentos tradutológicos que as unidades fraseológicas, carregadas de elementos culturais, suscitam. Para tanto, usaremos como base a classificação feita por Rodriguéz ${ }^{144}$ (2004, p.23-36 apud SILVA, 2006, p.17) e distinguiremos apenas as unidades fraseológicas consideradas sintagmas fraseológicos, ou seja, que não correspondem a enunciados completos, das paremias (em MPE, os enunciados proverbiais), que serão discutidas na parte sintática.

Alguns sintagmas exigiram certa pesquisa, feita no dicionário Le Robert Micro, no site do dicionário da TV5 Monde e no site do dicionário Bob-L'autre trésor de la langue. ${ }^{145}$ Elaboramos a tabela a seguir para esquematizar algumas das expressões consideradas mais representativas e suas respectivas traduções. Note-se que uma das tendências deformadoras analisadas por Berman, a do empobrecimento qualitativo, diz respeito "à substituição dos termos, expressões, modos de dizer etc. do original por termos, expressões, modos de dizer, que não têm sua riqueza sonora, nem sua riqueza significante ou - melhor — icônica" (2007, p.53). ${ }^{146}$ Não apenas no caso dos sintagmas fraseológicos, mas no conjunto da obra de Mabanckou, buscamos sempre atentar para a "substância sonora e corporal" das palavras, como diz Berman (Idem), de forma a procurar em português outras palavras que pudessem recriar essa linguagem.

Entretanto, cabe lembrar que nem sempre isso é possível, sendo a tradução inerentemente diferente do original. De nada adianta traduzir uma locução ou expressão, nos aproximando da iconicidade ou sonoridade original, se ela ficar demasiadamente

\footnotetext{
${ }^{143}$ No original: "unidades léxicas, formadas por más de dos palabras gráficas en su límite inferior cuyo límite superior se sitúa en el nível de la oración compuesta". CORPAS PASTOR, G. Manual de fraseologia española, Madrid: Gredos, 1997.

${ }^{144}$ RODRIGUÉZ, M. A. S. Unidades fraseológicas francesas - estúdio en un corpus: la Pentalogía de belleville de Daniel Pennac. Planteamiento didáctico. Tese (Doutorado en Filosofia y Letras) - Facultad de Filosofia y Letras. Universidad de Murcia, 2004.

${ }_{145}$ A saber: http://dictionnaire.tv5.org/dictionnaire e http://www.languefrancaise.net/Bob/Introduction.

146 Tradução de Marie-Helène Catherine Torres, Mauri Furlan, Andréia Guerini.
} 
exótica e de difícil entendimento para o leitor brasileiro. Portanto, ora optamos pela tradução por equivalência, ora pela tradução literal na acepção de Berman. ${ }^{147}$ Nas vezes em que optamos pela equivalência, buscou-se traduzir um sintagma por outro sintagma, se possível com características sintáticas semelhantes, na tentativa de construir ao menos uma estrutura parecida à do original. No caso das traduções literais, nem sempre a tradução configurou a estrutura de um sintagma fraseológico em português, sendo privilegiados aí os jogos semânticos e as imagens do original. Vejamos:

\section{Tabela 2 - Fraseologismos}

\begin{tabular}{|c|c|}
\hline Original & Comentário + tradução \\
\hline $\begin{array}{l}\text { "il aura cru sa vie } \\
\text { entière que je lui devais } \\
\text { quelque chose, que je } \\
\text { n'étais qu'un pauvre } \\
\text { figurant [...], eh bien, } \\
\text { sans vouloir tirer la } \\
\text { couverture de mon } \\
\text { côté, je peux aussi dire } \\
\text { la même chose à son } \\
\text { égard" (p.12) }\end{array}$ & $\begin{array}{l}\text { "tirer la couverture de son côté" é uma expressão usada no início da } \\
\text { história, quando o narrador conta que ele era fundamental para a } \\
\text { existência de seu mestre, que sem ele Kibandí não seria capaz de } \\
\text { nada. "Couverture", em francês, é a coberta, o que daria, numa } \\
\text { tradução literal, algo como "sem querer puxar a coberta para o meu } \\
\text { lado". O significado por trás da metáfora é o de tirar proveito de uma } \\
\text { situação, aproveitar algo que foi feito por outrem. Apesar de a } \\
\text { imagem ser muito interessante, a coberta não tem simbologia forte } \\
\text { para os brasileiros, talvez até pelo clima do país ser tropical e não } \\
\text { exigir com tanta frequência um cobertor. Assim, optamos por uma } \\
\text { tradução por equivalência, já que temos em português a expressão } \\
\text { "puxar brasa para a sua sardinha". Ao mesmo tempo, tomamos a } \\
\text { liberdade de modificá-la um pouco, e dessa forma mantivemos a } \\
\text { mesma estrutura do original, mudando apenas a imagem da coberta } \\
\text { pela da sardinha, já conhecida do leitor brasileiro. Ficou: "ele } \\
\text { acreditou a vida inteira que eu lhe devia alguma coisa, que eu não } \\
\text { passava de um pobre figurante [...], pois bem, sem querer puxar a } \\
\text { sardinha pro meu lado, eu também posso dizer a mesma coisa a } \\
\text { respeito dele". }\end{array}$ \\
\hline
\end{tabular}

\footnotetext{
${ }^{147}$ Analisando o caso dos provérbios, Berman diz, em A tradução e a letra, que a tradução literal não é "uma tradução palavra por palavra 'servil', mas da estrutura aliterativa do provérbio original que reaparece sob outra forma. Tal me parece ser o trabalho sobre a letra: nem calco, nem (problemática) reprodução, mas atenção voltada para o jogo dos significantes" (2007, p.16).
} 


\begin{tabular}{|c|c|}
\hline $\begin{array}{l}\text { "il n'avait jamais nui à } \\
\text { personne, se sont les } \\
\text { autres qui lui } \\
\text { cherchaient des poux } \\
\text { dans la tonsure" (p. } \\
\text { 24) }\end{array}$ & $\begin{array}{l}\text { No dicionário Bob, temos algumas variações para a expressão: } \\
\text { "chercher des poux sur la tête de qqun \& chercher des poux sur la } \\
\text { tête; chercher des poux dans la tête; chercher des poux à la tête de } \\
\text { qqun; trouver des poux sur la tête de qqun; chercher des poux sur le } \\
\text { crâne de qqun; chercher des poux à qqun". O significado literal é o de } \\
\text { procurar piolhos na cabeça de alguém; a metáfora diz respeito a } \\
\text { procurar briga, se intrometer nos assuntos dos outros, tentar difamar } \\
\text { ou prejudicar alguém. No romance, a expressão aparece no momento } \\
\text { em que o narrador conta sobre Jesus e seus feitos, dizendo que foi } \\
\text { injustamente punido. Poderíamos traduzir apenas seu significado, } \\
\text { deixando "eram os outros que vinham lhe importunar", mas a } \\
\text { iconicidade da expressão em francês carrega muito mais força do que } \\
\text { o simples significado denotativo do sintagma. Então, pensamos na } \\
\text { expressão conhecida em português "procurar chifre em cabeça de } \\
\text { cavalo", em que a brincadeira com o universo animal parece } \\
\text { interessante e apropriada. A estrutura muda um pouco (em francês a } \\
\text { expressão é direcionada à pessoa de quem se fala; em português não, } \\
\text { além de ser mais extensa), mas é similar: um verbo } \\
\text { [chercher/procurar] + um substantivo [des poux/chifre] + um } \\
\text { complemento de lugar [dans la tonsure/em cabeça de cavalo]: "ele } \\
\text { nunca tinha feito mal a ninguém, eram os outros que procuravam } \\
\text { chifre em cabeça de cavalo". }\end{array}$ \\
\hline $\begin{array}{l}\text { "notre vieux porc-épic } \\
\text { s'emportait, demandait } \\
\text { aux autres compères de } \\
\text { ne pas me quitter } \\
\text { d'une patte" (p.50) }\end{array}$ & $\begin{array}{l}\text { Aqui o próprio Mabanckou modificou a expressão, que originalmente } \\
\text { é "ne pas quitter d'une ombre", ou seja, não largar, seguir de perto } \\
\text { alguém. O jogo feito pelo autor é o de trocar "ombre" [sombra] por } \\
\text { "patte" [pata], remetendo assim ao universo animal de seu narrador. } \\
\text { Aparece no momento em que o porco-espinho começa a abandonar } \\
\text { sua comunidade animal, o que faz com que o velho governante peça } \\
\text { para os outros o seguirem, investigarem para onde ele está indo. Um } \\
\text { achado muito feliz foi o de termos nos lembrado da expressão, em } \\
\text { português, "não largar do pé de alguém", que tem o mesmo sentido. } \\
\text { Por conseguinte, também optamos pela referência animalesca, } \\
\text { traduzindo: "nosso velho porco-espinho se irritava, pedia aos outros } \\
\text { compadres para não largarem da minha pata" }\end{array}$ \\
\hline
\end{tabular}


“je dressai alors mes piquants sans avoir au l'animal [...], j'étais prêt à les projeter s'il le fallait puisque $\mathrm{j}$ 'en étais capable à la différence de la plupart de mes semblables, je n'eus pas besoin d'en arriver jusqu'à ce point, le jeu n'en valait pas la chandelle" (p. 61) préalable identifié

A expressão "le jeu n'en veut pas la chandelle" quer dizer, segundo Le Robert Micro (2006), "le résultat de cette entreprise ne vaut pas l'investissement, l'effort nécessaire". Em suma, corresponde a "não valer a pena" em português, que foi nossa primeira escolha. Depois, no entanto, ponderamos que uma expressão tão banal e corriqueira como esta não estava à altura da metáfora imagética poderosa do original. Afinal, Mabanckou poderia ter optado pela equivalente "cela n'en vaut pas la peine". O significado da expressão "le jeu n'en veut pas la chandelle" data do século XIX, quando se utilizavam castiçais para iluminar os jogos de apostas. Dizia-se que "o jogo não valia o castiçal" quando a soma de dinheiro ganhada era menor do que o preço do castiçal. A imagem, em português, julgamos ser muito obscura, de difícil entendimento. Procuramos, então, por uma expressão que remetesse, de alguma forma, ao original, seja pela estrutura, seja pela metáfora ou por algum elemento lexical. Chegamos por fim à expressão "usar as cartas na manga", que não tem o mesmo significado do original, mas remete ao jogo de cartas. Ter ou usar "cartas na manga" diz respeito a ter outros meios para conseguir algo, ou dispor de recursos inesperados, que surpreenderão caso venham a ser empregados. Acreditamos que essa expressão resolve o problema da inequivalência fraseológica, além de combinar com o sentido da oração, já que o narrador está dizendo que não foi preciso fazer uso de seus espinhos, pois o animal encontrado era apenas um velho rato. Vejamos a tradução: "ericei os meus espinhos sem nem ter identificado antes o animal [...], estava pronto para projetá-los se fosse necessário pois eu conseguia fazer isso diferentemente da maioria de meus iguais, não precisei chegar a esse ponto, não tive que usar as minhas cartas na manga".

Encontramos as locuções "rouler dans la farine" e "rouler comme une "et jusqu'à maintenant je n'en reviens toujours pas lorsque je revois comment il a roulé ce petit monde dans la farine" (p. 92) boulette dans la farine", que significam enganar, mentir. O narrador a utiliza quando conta as barbaridades que Kibandí fazia no vilarejo em que moravam sem que ninguém conseguisse provar sua culpa. Uma tradução literal ficaria algo como "rolou esse mundinho na farinha", o que pensamos soar muito estranho e sem sentido metafórico nenhum para o leitor brasileiro. Nos lembramos, felizmente, da expressão já conhecida em português "deitar e rolar", que pode ter o mesmo significado e ademais é formada também pelo verbo "rolar" [rouler], remetendo ao original. Seu uso nos obrigou, no entanto, a alternar a ordem da oração, deixando o complemento no final: "e até agora eu me surpreendo quando rememoro como ele deitou e rolou nesse mundinho". 


\begin{tabular}{|c|c|}
\hline $\begin{array}{l}\text { "si vous insistez, si } \\
\text { vous ne me croyez pas, } \\
\text { entrez donc à vos } \\
\text { risques et périls" } \\
\text { (p.96) }\end{array}$ & $\begin{array}{l}\text { Isso é o que diz o feiticeiro Tembê-Essuká quando recebe Tia Etalelí e } \\
\text { suas testemunhas, que procuram saber quem matou a jovem Nianguí- } \\
\text { Bussiná. É um dito de advertência, para alertar os visitantes que, se } \\
\text { entrarem, aceitam a responsabilidade do que lhes acontecer. Em } \\
\text { português, diríamos "entrem por sua conta e risco", mas não vimos } \\
\text { motivo para alternar a expressão em francês, uma vez que, } \\
\text { literalmente, ela é igualmente compreensível. Assim, deixamos: "se } \\
\text { vocês insistem, se não acreditam em mim, entrem então por seus } \\
\text { riscos e perigos". }\end{array}$ \\
\hline $\begin{array}{l}\text { "elle était paralysée, je } \\
\text { me rapprochai d'elle, je } \\
\text { l'entendis murmurer } \\
\text { des paroles sans queue } \\
\text { ni tête" (p. 139) }\end{array}$ & $\begin{array}{l}\text { "sans queue ni tête" refere-se a nossa famosa expressão "sem pé nem } \\
\text { cabeça". No romance, é usada na narração do assassinato da bela } \\
\text { Kiminú, primeiro ato bárbaro do narrador. Apesar de Mabanckou não } \\
\text { ter modificado a expressão francesa, que nesse caso de fato se refere à } \\
\text { cauda [queue] - ao invés de ao pé, como em português - e à cabeça } \\
\text { [tête], achamos interessante nos apropriarmos do possível jogo de } \\
\text { palavras para, quem sabe, compesar algum outro sintagma em que a } \\
\text { metáfora original se perdeu por completo. Desse modo, não usamos a } \\
\text { equivalente "sem pé nem cabeça", mas sim uma deformação } \\
\text { intencional dela, com o intuito de remeter ao universo animal que faz } \\
\text { parte do livro. Segue a tradução: "estava paralisada, me aproximei } \\
\text { dela, a escutei murmurar palavras sem pata nem cabeça". } \\
\text { Acreditamos que o leitor brasileiro, já muito familiarizado com a } \\
\text { locução "sem pé nem cabeça", fará a associação imediata da } \\
\text { expressão que modificamos e entenderá o sentido da oração. }\end{array}$ \\
\hline $\begin{array}{l}\text { "et ils demandèrent à } \\
\text { porter eux-mêmes le } \\
\text { cercueil sur leurs } \\
\text { épaules parce qu'ils } \\
\text { étaient persuadés que } \\
\text { quelque chose ne } \\
\text { tournait pas rond dans } \\
\text { cette pratique" (p. 143) }\end{array}$ & $\begin{array}{l}\text { "ne tourner pas rond" significa não ir bem, estar estranho, louco, } \\
\text { doente, ser suspeito, duvidoso, obscuro, causar problemas. A cena em } \\
\text { que aparece é a do ritual do cadáver delator, quando os etnólogos } \\
\text { pedem para eles próprios segurarem o caixão, certos de que o ritual } \\
\text { tem algo de estranho e duvidoso. Poderíamos traduzir simplesmente } \\
\text { por "alguma coisa não estava certa". Porém, em português brasileiro } \\
\text { existe a brincadeira com a propaganda de cerveja que "não desce } \\
\text { redondo", então achamos que essa imagem não dificultaria o } \\
\text { entendimento da expressão: "e pediram para levar eles mesmos o } \\
\text { caixão sobre seus ombros porque estavam persuadidos de que alguma } \\
\text { coisa não descia redondo nessa prática" }\end{array}$ \\
\hline
\end{tabular}




\begin{tabular}{|c|c|}
\hline $\begin{array}{l}\text { "et pourquoi pas les } \\
\text { montagnes pendant que } \\
\text { nous y sommes, hein, } \\
\text { elles peuvent aussi se } \\
\text { balader, les montagnes, } \\
\text { serrer la pince entre } \\
\text { elles dans un carrefour" } \\
\text { (p. 150) }\end{array}$ & $\begin{array}{l}\text { "serrer la pince" quer dizer "serrer la main", ou seja, se cumprimentar. } \\
\text { Na história, aparece num momento de digressão filosófica em que o } \\
\text { porco-espinho rememora tempos distantes, quando, segundo o velho } \\
\text { governante, as árvores podiam se locomover. Esse trecho específico } \\
\text { seria a resposta do homem, incrédulo, que questionaria porque só as } \\
\text { árvores, e não também as montanhas. Primeiramente, pensamos na } \\
\text { tradução por equivalência, que acarretaria simplesmente no verbo "se } \\
\text { cumprimentar". Posteriormente, no entanto, refletimos que a imagem } \\
\text { da "pince" pode remeter também ao universo animalesco, e que seria } \\
\text { interessante encontrar um jogo de palavras com isso. Em francês, } \\
\text { "pince" pode ser tanto uma pinça, um alicate, um utensílio para } \\
\text { pegar/agarrar algo, quanto o nome dado à extremidade de alguns } \\
\text { animais, a "garra". Logo, pensamos na opção "se dar as garras", por } \\
\text { analogia a "se dar as mãos", mas acreditamos soar muito mal em } \\
\text { português e ser de difícil assimilação. Em seguida, nos veio à mente o } \\
\text { verbo "agarrar", que deriva do substantivo "garra" e transmite a ideia } \\
\text { que queríamos. Optamos por "se agarras umas às outras", ao invés de } \\
\text { "se agarrar entre si", pois achamos que a segunda opção pode levar a } \\
\text { uma interpretação de conotação sexual (se beijam, por exemplo), o } \\
\text { que nos parece equivocado. Eis, então, a tradução final: "e por que } \\
\text { não as montanhas já que estamos sobre elas, hein, elas podem também } \\
\text { passear, as montanhas, se agarrar umas às outras num cruzamento" }\end{array}$ \\
\hline $\begin{array}{l}\text { "Youla allait savoir de } \\
\text { quel bois mon maitre } \\
\text { se chauffait" (p. 177) }\end{array}$ & $\begin{array}{l}\text { "de quel bois quelqu'un se chauffe" é uma expressão de ameaça, em } \\
\text { português correspondente a "do que alguém é capaz". Entendemos } \\
\text { que a ideia da madeira/fogueira para se aquecer é visualmente } \\
\text { bastante clara no contexto do livro, já que a expressão é utilizada no } \\
\text { momento em que Kibandí confronta Yulá para que este lhe pague o } \\
\text { dinheiro que deve, e Yulá o enfrenta, diz não estar devendo nada, o } \\
\text { que aguça a ira de Kibandí, que por fim decide se vingar. Pensamos } \\
\text { que, ao invés da equivalente "do que meu mestre era capaz", a } \\
\text { expressão literal pode ser facilmente compreendida pelo leitor } \\
\text { brasileiro: "Yulá ia saber com que fogueira o meu mestre se } \\
\text { aquecia". }\end{array}$ \\
\hline $\begin{array}{l}\text { "mon maître était alors } \\
\text { loin de savoir qu'il } \\
\text { venait de signer son } \\
\text { acte de décès en me } \\
\text { confiant cette mission } \\
\text { qui serait le centième } \\
\text { succès, pardon, le cent } \\
\text { unième puisque nous } \\
\text { ferions d'une pierre } \\
\text { deux coups" (p. 186) }\end{array}$ & $\begin{array}{l}\text { "faire d'une pierre deux coups" significa alcançar dois objetivos, } \\
\text { realizar duas coisas com uma só ação, ou, em português, "matar dois } \\
\text { coelhos com uma cajadada só". No romance, significa que Kibandí e } \\
\text { seu duplo, o narrador, iriam executar uma única missão, mas } \\
\text { matariam duas pessoas. Optamos, no entanto, por uma tradução } \\
\text { literal, que não deixa de transmitir a exata ideia e se faz entender: "o } \\
\text { meu mestre estava então longe de saber que ele acabava de assinar a } \\
\text { sua sentença de morte ao me confiar essa missão que seria o } \\
\text { centésimo sucesso, perdão, o centésimo primeiro já que nós daríamos } \\
\text { dois golpes com uma só pedra" }\end{array}$ \\
\hline
\end{tabular}

Esses 11 exemplos de sintagmas fraseológicos encontrados no romance servem de base para demonstrar nossa lógica tradutória em relação às transferências culturais de 
maneira geral. Tomamos a liberdade de brincar com algumas expressões em português, da mesma maneira que Mabanckou brinca, em francês, com outras, aproximando o leitor do universo criado pelo autor, ao invés de automaticamente traduzir por equivalência. Pensamos, assim, que, se em alguns momentos perdemos as metáforas ou jogos de palavras recriados pelo autor, noutros criamos novos jogos, dessa forma compensando a estrutura que julgamos pertinente à narrativa.

As referências culturais são também vistas no vocabulário em língua autóctone, que na maioria das vezes recebe a explicação de seu significado na sequência, como se fosse uma nota do próprio autor incorporada ao texto. Essas palavras se referem aos topônimos e antropônimos — aliás, são as únicas que ganham letra maiúscula no romance - , e a alguns termos específicos pertencentes à cultura congolesa relacionados a nomes de comidas, bebidas, materiais ou insultos. Entendemos que nomear as personagens e lugares a partir de referências congolesas é uma maneira de caracterizálas, dar-lhes uma identidade individual e coletiva.

Como vimos no Capítulo 1 e 2, o francês é uma das línguas maternas do autor e é língua oficial da República do Congo, que conta também com várias outras línguas bantu. Isso posto, pensamos que a brincadeira que Mabanckou faz, no romance, é a de transmitir a atmosfera sociocultural congolesa ao introduzir palavras desconhecidas para o público francês. Nesses casos, pois, o que importa é menos o conteúdo e mais o som das palavras. O léxico autóctone marca o hibridismo cultural do autor e, por consequência, de suas personagens, além de evidenciar a horizontalidade entre as línguas: ao deixar de traduzir as palavras em língua bantu para o francês, o autor coloca essas duas línguas numa relação de igualdade, o que também pretendemos ao não aclimatar o vocabulário para o público brasileiro. Pensamos que o apagamento dessas marcas autóctones seria uma forma etnocêntrica de traduzir, priorizando a línguacultura de chegada, configurando uma estratégia contrária ao nosso projeto tradutório.

No entanto, adaptamos a acentuação e grafia das palavras para o padrão fonético do português, pois mantê-las como no original causaria um deslocamento fonético para o leitor brasileiro e, por conseguinte, o estranhamento almejado soaria exótico demais. Logo, assim como o leitor francês depara com nomes estrangeiros, congoleses, mas os lê segundo grafia francesa, o leitor brasileiro terá sensação semelhante ao ler esse tipo de vocabulário, que seguirá a fonética do português. 
Vejamos alguns exemplos:

\begin{tabular}{|c|c|}
\hline $\begin{array}{l}\text { "tu es incapable de grimper même à un } \\
\text { manguier, des types comme toi sont des } \\
\text { foireux, des maniongi, des ngébés, des } \\
\text { ngoubas ya ko pola', Kibandi n'a pas } \\
\text { répondu à ces insultes en langue bembé" (p. } \\
\text { 172) }\end{array}$ & $\begin{array}{l}\text { é incapaz até mesmo de subir numa } \\
\text { mangueira, tipos como você são estragados, } \\
\text { maniongí, ngêbês, ngubás ya ko polá", } \\
\text { Kibandí não respondeu a esses insultos em } \\
\text { língua bembê }\end{array}$ \\
\hline $\begin{array}{l}\text { "je suis alors revenu vers la case de mon } \\
\text { maître un peu plus tard, avec le danger d'être } \\
\text { localisé par les chiens batékés" (p. 34) }\end{array}$ & $\begin{array}{l}\text { então voltei à cabana do meu mestre um } \\
\text { pouco mais tarde, com o perigo de ser } \\
\text { localizado pelos cães batêkês }\end{array}$ \\
\hline $\begin{array}{l}\text { "encore faut-il parvenir à lui faire avaler le } \\
\text { breuvage initiatique appelé mayamvumbi" (p. } \\
\text { 17) }\end{array}$ & $\begin{array}{l}\text { é preciso ainda fazer com que ela engula a } \\
\text { bebida iniciática chamada mayamvumbí }\end{array}$ \\
\hline $\begin{array}{l}\text { "ils logeaient dans une case en planches } \\
\text { d'okoumé" (p. 111) }\end{array}$ & $\begin{array}{l}\text { alojaram-se em uma cabana de tábuas de } \\
\text { okumê }\end{array}$ \\
\hline $\begin{array}{l}\text { "je vais te préparer le meilleur plât de } \\
\text { Kinkosso, le ngul' mu mako" (p. 118) }\end{array}$ & $\begin{array}{l}\text { vou lhe preparar o melhor prato de } \\
\text { Kinkosso, o ngul' mu makô }\end{array}$ \\
\hline $\begin{array}{l}\text { "il savait tirer le mwengué, le meilleur vin } \\
\text { qu'un palmier puisse donner" (p. 169) }\end{array}$ & $\begin{array}{l}\text { ele sabia como retirar o mwenguê, o melhor } \\
\text { vinho que uma palmeira podia dar }\end{array}$ \\
\hline
\end{tabular}

Com exceção dos dois primeiros exemplos, em todos os outros vemos a explicação do termo no próprio texto. No primeiro exemplo, na verdade, o conjunto de palavras é explicado, são "insultos", apenas não sabemos pontualmente o significado de cada uma das palavras. No exemplo 2, batêkês está associado a cães, e imagina-se que se refere a um tipo de cão. Para esse caso, especificamente, criamos uma nota de rodapé de caráter cultural, como elemento extra para o leitor (ver Apêndice A com as notas de rodapé).

Sobre os topônimos e antropônimos, alguns exemplos e suas respectivas adaptações seriam:

a) Topônimos: Sêkêpembê [Séképembé]; Lubulu [Louboulou]; Kinkossô [Kinkosso]; Kimandu [Kimandou]; 
b) Antropônimos: Kibandí [Kibandi]; Tembê-Essuká [Tembé-Essouka]; Mundjulá [Moundjoula]; Mubungulú [Mouboungoulou]; Ngumbá [Ngoumba]; Nkêlê [Nkélé]; Nkuyú Matêtê [Nkouyou Matété]; Amêdê [Amédée]; Yulá [Youla].

Além dessas anotações de cunho mais substancialmente cultural, o segundo elemento primordial deste bloco semântico relaciona-se aos registros de língua. ${ }^{148}$ Sabemos que a mescla entre linguagem formal e informal reina na prosa de $M P E$, de forma a recriar o universo de contação de histórias e, ao mesmo tempo, não infringir as ditas "normas" ou "regras" da gramática tradicional francesa, conforme discutimos nos capítulos antecedentes. No que concerne à tradução dessa mescla, achamos fundamental nos atentarmos ao léxico familiar, informal, às gírias e ao vocabulário de baixo calão, procurando, em português, formas que possam dialogar com esses campos.

Segundo Le Robert Micro (2006), uma palavra "familiar" é aquela "que empregamos na conversação corrente e por escrito, mas que evitamos em relações com superiores, nas relações oficiais e nas obras sérias". ${ }^{149}$ Assim, nos parece de extrema importância que Mabanckou tenha escolhido inserir em um texto considerado "sério" (literário) esse tipo de léxico, corroborando com nossa interpretação de que existe, de fato, uma mistura de registros não aleatória.

Vimos, na esfera macroestrutural, que a informalidade do discurso do porcoespinho aparece, sobretudo, na sua relação com a árvore. Ao selecionarmos os exemplos seguintes de léxico familiar, nos demos conta de que são elementos de apoio discursivo, quer dizer, são marcas da dinâmica dialogal entre o narrador e o baobá. Segundo Gadet, em seu estudo sobre o francês popular, os "apoios discursivos" aparecem em posição inicial nos trechos de discurso direto, ou em pontos de articulação. Nesses casos, diz o autor, eles são comparáveis a pausas, hesitações ou rupturas de entonação, ou seja, "trazem um tipo de pontuação ao discurso" (1992, p.32). ${ }^{150}$ Isso pode ser observado nos trechos a seguir:

\footnotetext{
${ }^{148}$ Usamos o termo "registro de língua" para tratar de maneira geral dos registros familiar, popular, gírias e, também, do registro formal, uma vez que todos eles se misturam na narrativa do porco-espinho. Entende-se, aqui, que "não existe locutor uni-estilo, e um locutor do francês popular, como todo locutor, tem acesso a diferentes registros" [il n'y a pas de locuteur uni-style, et un locuteur du français populaire, comme tout locuteur, a accès à différents registres] (GADET, 1992, p.22).

${ }^{149}$ No original: "qu'on emploie dans la conversation courante et par écrit, mais qu'on évite dans les relations avec des supérieurs, les relations officielles et les ouvrages sérieux".

${ }^{150}$ No original: "apportent une sorte de ponctuation au discours".
} 
a) "voilà": é muito usado em francês e tem diversas acepções. Pode designar uma pessoa ou coisa, ser uma exclamação para enfatizar algo, designar algo que acaba de ser dito no discurso ou apresentar uma circunstância nova. Não existe palavra semelhante em português, mas muitas outras formas com mesma função no discurso. No romance, são várias as ocorrências de "voilà", e algumas das soluções que encontramos foram:

voilà comment nous sommes devenus bien malgré nous des habitants de ce village, un village d'accueil où nous aurions pourtant pu vivre une vie normale (p. 108) foi assim que nos tornamos a contragosto habitantes deste vilarejo, um vilarejo de acolhimento onde teríamos podido entretanto viver uma vida normal

Esse trecho é a conclusão da parte "como Papai Kibandí nos vendeu o seu destino" e a expressão "voilà comment", nesse caso, tem a intenção de dar fechamento à história do capítulo. Em português, usamos "foi assim que" para traduzir essa intenção, da mesma maneira que falamos oralmente para terminar de relatar algo.

O próximo exemplo tem o termo "en voilà" dito no início de uma fala dos aldeões do vilarejo. A fala tem valor de fofoca, pois o narrador está em vias de explicar como o vinho mwenguê do velho Moudionguí era o mais doce, porém o de maior teor alcoólico, e então era fácil perceber quando alguém o tinha tomado, e as pessoas comentavam:

"en voilà encore un qui a consommé le mwengué du vieux Moudiongui”' (p. 170)

“olha aí mais um que consumiu o mwenguê do velho Mudionguî"

O termo não tem o mesmo valor do trecho anterior, sendo aqui possível até mesmo imaginar a fala seguida de um gesto com o dedo, apontando para a pessoa. Em português traduzimos por "olha aí", que remete ao gesto e contexto falado. 
Nos dois trechos seguintes, a acepção de "voilà" é ainda diferente das duas anteriores, sendo utilizado como forma de apresentar um fato novo e surpreendente. Em português, pensamos que o termo que mais se assemelharia a esse seria "eis que", porém, devido a sua formalidade, achamos inviável utilizá-lo. Desse modo, procuramos diferentes soluções, de acordo com o contexto. No primeiro exemplo, o narrador está iniciando um novo capítulo, fazendo uma digressão e se abrindo com a árvore, contando suas angústias. O "voilà", nesse caso, marca a interação com a árvore e evidencia o tempo presente, o imediatismo da fala do porco-espinho. Optamos por uma tradução que também remetesse ao momento de enunciação, e por isso acrescentamos o "aqui" e mudamos o verbo para o gerúndio, o que interferiu no comprimento da oração e, assim, desacelerou o ritmo narrativo:

nom d'un porc-épic, qu'est-ce que le temps passe vite, j'ai la voix enrouée, la nuit est déjà tombée sur Séképembé, voilà que je pleure sans comprendre pourquoi (p. 187) palavra de porco-espinho, como o tempo passa rápido, estou rouco, a noite já caiu sobre Sêkêpembê, e eu aqui chorando sem compreender por que

Já no segundo exemplo, o animal está contando que seus companheiros pensavam muito em sexo, enquanto ele não. Surpreende-se, no entanto, quando fica excitado ao ver uma moça nua. É nesse momento em que usa o "voilà", expressando sua surpresa diante da situação. Nesse caso, pensamos em traduzir o termo por um, em português, que também expressasse surpresa e fosse, ao mesmo tempo, informal. Chegamos a "veja só": 
je n'y pensais pas à la différence de certains membres de notre groupe de l'époque qui se livraient à ces basses choses quand le vieux gouverneur avait le dos tourné, ils étaient plus âgés que moi, ces compères, et puis voilà que le jour de cette première mission il y avait une escroissance soudaine entre mes pattes de derrière, mon sexe qui se durcissait (p. 135) não pensava nisso ao contrário de certos membros do nosso grupo na época em que se entregavam a essas coisas baixas quando o velho governante nos dava as costas, eles eram mais velhos que eu, esses companheiros, e depois veja só no dia dessa primeira missão vi uma excrescência repentina entre as minhas patas de trás, o meu sexo que endurecia

b) "se tenir": em sua forma pronominal, "se tenir" quer dizer segurar algo para que não caia, ou para que não mude de posição, ou ainda continuar, permanecer em uma posição. Entretanto, na linguagem oral, possui outro significado, que também marca a interação com o interlocutor, chamando sua atenção. Nos dois exemplos a seguir fica clara essa ideia:

et il est venu sur terre pour sauver l'humanité entière, y compris nous autres les animaux parce que, tiens-toi bien, déjà à une époque loitaine, [...], on nous avait aussi groupés dans cette cage baptisée Arche de Noé (p. 23) e ele veio à terra para salvar a humanidade inteira, incluindo nós os animais porque, escute bem, já em tempos remotos, [...], também nos agruparam nessa caixa batizada de Arca de Noé

Esse é o trecho já comentado anteriormente no qual o narrador discorre sobre a Bíblia e fala sobre Jesus, relatando seus feitos com certa incredulidade. Nessa passagem, a expressão "tiens-toi bien” é empregada para chamar a atenção da árvore, sua interlocutora, para a misteriosa história do filho de Deus, que veio para a terra e salvou a humanidade. Procuramos, em português, uma expressão que também fosse utilizada nesse sentido de chamar a atenção, e nos veio em mente o "escute bem", que além de tudo remete ao discurso oral, e não ao escrito (pelo verbo escutar, não ler). 
Esse trecho faz parte do anexo do livro, a carta do Escargô cabeçudo à editora, na qual ele explica como o manuscrito foi reconstituído por ele e datilografado por uma estudante que alegou ser a escrita de Verre Cassé muito complicada, e por isso cobrou esse valor alto. A expressão “tenez-vous bien”, nesse caso, tem a mesma acepção da do trecho anterior, com a diferença de ser esta uma passagem formal, além de ser usada por Verre Cassé, não mais pelo narrador direcionando-se ao baobá. Como nesse caso é uma carta que estamos lendo, e não há mais a atmosfera oral do restante do livro, optamos por traduzir por "vejam bem”, e não "escutem bem”.

c) "tu parles": é um vocabulário familiar que pode ser, segundo o dicionário Bob, uma fórmula de confirmação afirmativa ou, ao contrário, uma expressão irônica, de dúvida. No romance aparece uma única vez, também no momento em que o narrador fala sobre Jesus. Diz:

et ils l'ont tué, ce pauvre fils de Dieu, mais tu parles, il est revenu du Royaume des morts comme quelqu'un qui se réveillait d'une petite sieste de rien du tout (p. 23) e eles o mataram, esse pobre filho de Deus, mas você acha, ele voltou do Reino dos mortos como alguém que acordava de uma pequena siesta de nada

Entendemos que é também uma marca da interação do narrador com a árvore, e vemos que, pelo contexto, tem valor irônico, já que o filho de Deus não morre de fato. Em português, pensamos em várias opções, como "mas mentira" ou "mas até parece", mas quisemos manter o pronome sujeito "tu" [você] e empregar uma expressão bastante comum oralmente, "você acha".

Outras passagens no romance em que se nota a mescla de registros de língua não marcam diretamente a interação entre o narrador e o baobá, mas sim o caráter 
espontâneo e informal da narrativa. Um exemplo em que é possível analisar não somente isso como também alguns aspectos sintáticos interessantes — a negação sem o "ne" e a contração de "cela", que vira "ça", os quais trataremos nas anotações sintáticas - é o seguinte:

a)

“je t'épie depuis, je me demandais bien "e pourquoi tu pleurais comme ça, c'est donc parce que tu cherches les tiens, n'est-ce pas, hein, à vrai dire j'ai pas vu de porc-épic rôder dans le coin depuis quelques jours, c'est plutôt très calme par ici ces derniers temps, à croire qu'y a plus rien à bouffer et que tout le monde se barre" (p. 74) "estou espiando-o faz um tempo, me perguntava mesmo por que você chorava assim, é então porque está procurando os seus, num é, hein, para dizer a verdade num vi não nenhum porco-espinho andando por essas bandas faz alguns dias, pelo contrário está bem calmo por aqui nos últimos tempos, parece que num tem mais nada não para rangar e que todo o mundo dá no pé"

À parte as questões sintáticas, temos nesse trecho a fala de um esquilo que tenta ajudar o narrador no momento em que este se vê perdido e desamparado. A fala do esquilo é informal, como vemos no emprego de "bouffer" que, em linguagem familiar, quer dizer "manger", e de "se barrer" que, também na linguagem familiar, significa "partir, s'enfuir". Em português, optamos por "rangar" e "dar no pé", também informais.

b) "gueule", que designa a boca dos animais, ficou "goela", palavra que significa garganta, mas que é usada informalmente no mesmo sentido que aparece na narrativa, além de apresentar sonoridade semelhante:

le bout de bois qu'il lança tomba à quelques centimètres de ma gueule (p. 163) o pedaço de madeira que ele lançou tombou a alguns centímetros da minha goela 
c) "truc", que é o vocabulário informal para "chose" [coisa], traduzimos por "treco", que tem mesmo sentido e sonoridade:

"tes trucs que tu fais dans ce village avec celui qui t'a envoyé ici, c'est pas à moi que tu les feras, tu es mal tombé, pauvre imbécile" (p. 184) "os trecos que você faz neste vilarejo junto àquele que o enviou aqui, não é a mim não que os fará, você se deu mal, pobre imbecil"

d) "dare-dare" é um termo familiar que significa imediatamente, prontamente: "je suis sorti dare-dare de l'antre" (p. 33) ficou, em português, "saí rapidinho da gruta";

e) "de guingois" é uma locução adverbial familiar que quer dizer de maneira oblíqua, torta: "je progressais de guingois" (p. 38)/ andava em zigue-zague;

f) “puceau” é o termo familiar para homem virgem: “elle n'appréciait pas trop qu'on lui impose un puceau" (p. 118)/ ela não apreciava muito que lhe impusessem um novinho.

E há também o léxico pejorativo:

a) "garnement", que em francês significa uma criança turbulenta, insuportável, é usado no livro em referência aos gêmeos Koty e Kotê, os dois meninos do vilarejo perspicazes e levados, que acabam por descobrir a verdade sobre Kibandí e matá-lo. Traduzimos, em português, para "diabinho", que no diminutivo deixa claro tratar-se de uma criança e mantém a conotação pejorativa do original. Um trecho seria:

"pauvres garnements, vous manquez d'éducation, pourquoi vous me traitez de méchant, hein, est-ce que vous savez que je peux le dire à votre père" (p. 199) "pobres diabinhos, vocês não têm educação, por que me tratam de malvado, hein, será que vocês sabem que posso contar ao seu pai"

b) "chenapan" pode significar "canalha", porém quando se refere a crianças é menos pesado, designando alguém com malícia. Traduzimos o termo por "atrevido" no seguinte trecho, quando os gêmeos Koty e Kotê pegam o duplo de Kibandí:

et les deux chenapans le ballotaient au gré de leurs caprices, ils le roulaient dans la poussière, essayaient de le mettre sur pied [...] (p. 207-208) e os dois atrevidos o balançavam segundo os seus caprichos, o rolavam na poeira, tentavam colocá-lo em pé 
c) "gaillard", em francês, tem várias acepções, uma delas sendo "homem cheio de vigor e dinamismo" [Homme plein de vigueur et d'entrain], segundo Le Robert Micro (2006). Já no dicionário online da TV5 Monde, uma das acepções é "quem tem coragem, robusto" [qui a de la vaillance, robuste]. No livro, pelo contexto, vemos que o termo é utilizado sempre para referir-se a homens valentes, que vão caçar duplos nocivos ou que carregam caixões nos rituais do vilarejo. Logo, optamos por traduzi-lo por "valentão", por exemplo no trecho a seguir:

il fallait capturer Papa Kibandí à son insu, on confia donc à douze gaillards la mission d'aller traquer le vieux rat dans la forêt (p. 106) era preciso capturar Papai Kibandí sem o seu conhecimento, confiaram então a doze valentões a missão de ir caçar o velho rato na floresta

d) "putain" é um termo muito comum na linguagem familiar francesa, sendo usado em diferentes situações, tanto como ofensa quanto como interjeição marcando uma exclamação. Na história, aparece algumas vezes, a maior parte delas seguindo a estrutura "pronome demonstrativo + putain + de + substantivo", que foi traduzido, da mesma maneira, por um pronome demonstrativo + merda + de + substantivo, já que fortuitamente o substantivo "merda" é muito usado no português informal e pode apresentar estrutura idêntica. Exemplos disso estão nas páginas 124 "cette putain de maladie" [essa merda de doença] e 143 "on va enfin terminer ce putain de bouquin" [vamos enfim terminar essa merda de livro], ou ainda na página 145:

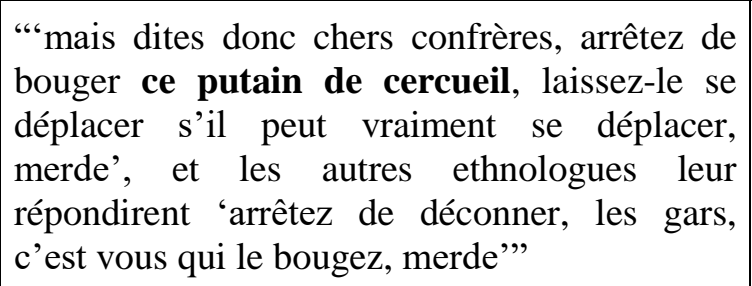
bouger ce putain de cercueil, laissez-le se déplacer s'il peut vraiment se déplacer, merde', et les autres ethnologues leur répondirent 'arrêtez de déconner, les gars, c'est vous qui le bougez, merde",

"“mas digam então queridos colegas, parem de mexer essa merda de caixão, o deixem se deslocar se é que ele pode de verdade se deslocar, merda', e os outros etnólogos responderam 'parem de brincadeira, gente, são vocês que o estão mexendo, merda"”

Nesse exemplo podemos observar não somente o emprego do "putain", mas também outras marcas informais no diálogo entre os etnólogos, como o uso de 
“déconner", que significa dizer absurdos, besteiras, e que traduzimos por "parem de brincadeira", e "gars", que em francês é o mesmo que menino ou homem, mas foi, no entanto, traduzido por "gente", dado que se tratava de um plural informal e que essa é a maneira informal que usamos num contexto semelhante. Note-se, infelizmente, que ao traduzirmos "putain" por "merda" perdemos a riqueza vocabular da passagem, já que "merde”, também traduzido por "merda", aparece na sequência duas vezes.

e) "bordel" é um adjetivo que pode designar uma casa de prostituição ou, na linguagem familiar, uma grande desordem ou um lugar onde há desordem, segundo Le Robert Micro (2006). No romance, no entanto, entendemos seu uso como uma marcação de exclamação, e por consequência o traduzimos por "caramba" em português. Vejamos o seguinte trecho:

\begin{tabular}{|c|c|}
\hline $\begin{array}{l}\text { "vous n'avez pas encore compris que ce vieux } \\
\text { qui est ici et que vous accusez de ce malheur } \\
\text { n'est pas celui qui a mangé votre fille, hein, je } \\
\text { vais vous le dire combien de fois, bordel, et } \\
\text { maintenant si vous insistez à connaître la } \\
\text { vérité, je vais vous la dévoiler" (p. } 98 \text { ) }\end{array}$ & $\begin{array}{l}\text { "ainda não compreendeu que este velho que } \\
\text { está aqui e que a senhora acusa dessa } \\
\text { desgraça não é aquele que comeu a sua filha, } \\
\text { hein, vou dizer quantas vezes, caramba, e } \\
\text { agora se insiste em conhecer a verdade, eu } \\
\text { vou lhe revelar" }\end{array}$ \\
\hline
\end{tabular}

f) Alguns outros vocabulários familiares pejorativos e suas traduções são: "saoulard", que quer dizer bêbado, traduzido por "bebum"; "salaud", que é usado para designar alguém desprezível, revoltando ou desagradável, traduzido por "vagabundo"; "vaurien" é um sujeito ruim, um "malandro"; "petite peste" tem tradução transparente, ficou "pestinha".

\subsection{Anotações sintáticas}

Os comentários a seguir concernem fundamentalmente aos problemas de intervenção sintática, devido às diferenças linguísticas entre o francês e o português. Por isso, algumas vezes fomos levados a aplicar procedimentos de supressão, contração e alternância na ordem da oração, sempre visando um melhor resultado rítmico para a passagem, ou seja, de alguma forma encontram-se aqui também notas estilísticas. 
Privilegiamos aqui os elementos macro e microestruturais, vistos no Capítulo 2, considerados "padrões obsessivos" do texto, quer dizer, elementos recorrentes responsáveis pelo ritmo e cadência da narrativa, conforme diz Ana Cristina Cesar. Em primeiro lugar, identificamos o uso das vírgulas como única forma de pontuação, encadeando uma frase na outra, o que, na verdade, faz com que a pontuação se transfira para outros elementos do texto. Assim, observa-se que o "fluir sintático" de que fala Ana Cristina Cesar (1999, p.365) aparece nas construções de paralelismo, no uso repetido de interjeições, conjunções, estruturas, pronomes.

Tentamos, portanto, reproduzir o ritmo visto no original pela retomada da pontuação, da estrutura e da extensão das orações em francês. De acordo com Berman (2007, p.49), a prosa tem "uma estrutura em arborescência (repetições, proliferação em cascata das relativas e dos particípios, incisos, longas frases, frases sem verbo etc.) que é diametralmente oposta à lógica linear do discurso enquanto discurso". Segundo ele, a alteração da estrutura sintática, principalmente no que se refere à pontuação, acaba por colocar em ordem um discurso que não o é.

Essa tendência deformadora, que ele chama de racionalização, própria a uma tradução etnocêntrica, procuramos não utilizá-la demasiadamente. No entanto, uma vez que a sintaxe está ligada ao conteúdo, foi preciso, em alguns casos, modificar a ordem das palavras ou eventualmente alguma vírgula para que o conteúdo não fosse perdido. Trataremos destes e de outros casos ao longo deste subitem.

Sobre a pontuação especificamente, podemos citar, a título de exemplo, o trecho a seguir, momento em que Tia Etalelí quer descobrir quem matou sua filha e pede a ajuda de Tembê-Essuká, o feiticeiro, que diz:

"[...] si vous insistez, si vous ne me croyez pas, entrez donc à vos risques et périls", puisque Tante Etaleli était plus que jamais déterminée le groupe pénétra dans la case, ce ne sont pas les odeurs putrides qui rebutèrent les six arrivants mais plutôt les masques qui semblaient vexés par l'opiniâtreté et la témérité de ces étrangers, Tembé-Essouka avait le regard humide et éteint [...] (p. 96-97)
"[...] se vocês insistem, se não acreditam em mim, entrem então por seus riscos e perigos", já que Tia Etalelí estava mais que nunca determinada o grupo penetrou na cabana, não foram os odores pútridos que afastaram os seis recém-chegados mas antes as máscaras que pareciam vexadas pela obstinação e pela temeridade desses estrangeiros, Tembê-Essuká tinha o olhar úmido e apagado [...] 
Nessa passagem, as vírgulas marcam frases curtas no início, quando quem fala é o feiticeiro, em tom de alerta. As frases curtas e as vírgulas contribuem para a cadência da cena, diminuindo o ritmo do relato, como forma de também mostrar o receio ou o alerta para o que se seguiria. As últimas cinco linhas, no entanto, desde "ce ne sont pas" até "ces étrangers", não apresentam uma única vírgula, e isso também não parece acidental. É nesse momento que os visitantes entram na cabana do feiticeiro, apesar de suas ressalvas, e então o ritmo contínuo das frases, sem vírgulas e interrupção, contribui para criar a atmosfera de surpresa, atordoamento ou medo sentido pelas personagens. $\mathrm{Na}$ tradução, não alteramos a estrutura das vírgulas, mesmo em momentos em que seria apropriado inserir uma pausa, como logo antes do "mas".

Além da pontuação, as duas características ("obsessões”, como diria Ana Cristina Cesar) sintáticas primordiais que reconhecemos no texto de Mabanckou são os paralelismos e as repetições de interjeição, conjunção, verbo, pronome, estrutura. Vimos no Capítulo 2 alguns exemplos disso, que reforçaram a noção de que sintaxe e conteúdo (aqui remetendo às narrativas orais) agem conjuntamente. Acreditamos que essas duas características são responsáveis por acelerar ou diminuir a tensão da cena contada.

Na página 16, no início da história, o narrador conta como era feito o ritual de iniciação da criança para receber seu duplo. Nesse trecho, a sequência de verbos e a aliteração do "l" transmitem uma ideia de balanço, de chacoalho, acelerando a narração. $\mathrm{Na}$ tradução, não conseguimos reproduzir a mesma aliteração, porém encontramos verbos de três sílabas, começando com "a" e com aliteração no "g", o que causou um efeito semelhante na sequência: "o agride, afaga, agita":

la transmission d'un tel pouvoir est assurée par le grand-père dès la naissance de l'être humain, ce vieux s'empare du nourrisson après consultation de ses géniteurs, il disparaît avec lui derrière la case, il lui parle, crache sur lui, le lèche, l'agite, le chatouille, le balance en l'air, le rattrape (Idem, p. 16) a transmissão de tal poder é assegurada pelo avô desde o nascimento do ser humano, o velho pega o recém-nascido depois de consultar os seus genitores, desaparece com ele atrás da cabana, fala com ele, o agride, afaga, agita, faz cócegas, joga pra cima, pega de volta 
Em outro momento, o narrador explica que os homens não detêm o monopólio do pensamento, já que os fantasmas também pensam, apesar de não os enxergarmos. $\mathrm{O}$ animal elenca várias ações que os fantasmas fazem numa sequência de nove verbos no presente e no futuro próximo [ir + verbo no infinitivo], como forma de enfatizar e embasar seu argumento, terminando por relembrar que, a despeito de tudo isso, não conseguimos vê-los. A sequência de ações enumeradas pelo porco-espinho dá à narrativa um ritmo mais acelerado, sendo o leitor capaz de visualizar os ditos fantasmas realizando todas essas peripécias uma após a outra, e é apenas no final que a narração retoma um passo mais calmo, quando os verbos cessam e lemos "et pourtant" [e entretanto], que quebra com a ordem estabelecida até então.

or j'ai toujours soutenu que les hommes n'avaient pas le monopole de la pensée, d'ailleurs les habitants de Séképembé affirment que les fantômes aussi réfléchissent puisqu'ils reviennent épouvanter les vivants, retrouvent sans difficulté les sentes qui mènent au village, déambulent dans les marchés, vont jeter un oeil dans leur ancien domicile, vont annoncer leurs mort dans les villages environnants, s'attablent dans une buvette, commandent du vin de palme, boivent comme des éponges, tiennent à payer les dettes qu'ils ont contractées de leur vivant, et pourtant ils n'existent pas à l'oeil nu (p. 30) ora eu sempre sustentei que os homens não tinham o monopólio do pensamento, por outro lado os habitantes de Sêkêpembê afirmam que os fantasmas também pensam já que eles retornam para assombrar os vivos, encontram sem dificuldades os caminhos que levam ao vilarejo, perambulam pelos mercados, vão dar uma olhadinha nos seus antigos domicílios, vão anunciar a sua morte nos vilarejos ao redor, se sentam num bar, pedem vinho de palma, bebem como esponjas, dizem pagar as dívidas contraídas enquanto vivos, e entretanto eles não existem a olhos nus

A mesma ideia da repetição usada para enfatizar um argumento pode ser vista no trecho a seguir, quando o porco-espinho relata os feitos de Jesus, que é tido pelos humanos como alguém único e especial, apesar de, assim como no caso dos fantasmas, nunca o terem visto de fato. Nesse exemplo, a repetição não é apenas verbal, mas sim estrutural: "c'est encore lui qui + verbo no imperfeito" é repetido quatro vezes em um trecho de poucas linhas, trazendo cadência à narrativa e, também, sendo responsável por uma pitada de ironia no discurso do narrador, que argumenta em seguida não entender como os humanos creem tanto em algo que nunca viram. Entende-se que o uso repetido dessa expressão não é aleatório, pois revela a opinião do narrador, como se estivesse 
questionando, nas entrelinhas, como é possível uma única pessoa fazer tantas coisas sobrenaturais sozinha. O uso do imperfeito, ademais, marca a continuidade da ação, sendo responsável por enfatizar a argumentação do porco-espinho. Analogamente ao trecho anterior, o ritmo é desacelerado no momento em que se introduz a conjunção "e". Note-se que, na tradução, optou-se por inverter a ordem da estrutura [“é ele também que", ao invés de "é também ele que"] na primeira aparição, e nas demais suprimimos o pronome sujeito, dispensável em português, e modificamos a estrutura para deixar o texto mais cadenciado:

c'est ce type qui se baladait sur les eaux, c'est encore lui qui transformait de l'eau en vin, c'est encore lui qui multipliait les petits pains pour nourrir le peuple, c'est encore lui qui respectait les prostituées sur qui la population jetait la pierre, c'est encore lui qui redonnait des jambes aux paralytiques les plus désespérés, et il est venu sur terre pour sauver l'humanité entière (p. 22-23) é esse tipo que passeava nas águas, é ele também que transformava água em vinho, e que também multiplicava os pães para alimentar o povo, e que também respeitava as prostituídas sobre quem a população jogava pedras, e que também restituía pernas aos paralíticos mais desesperados, $\underline{\mathrm{e}}$ ele veio à terra para salvar a humanidade inteira

No próximo exemplo, a repetição verbal é precedida pela conjunção "que", também no mesmo intuito de enumerar ações do porco-espinho que seriam, para o velho governante, reprováveis. Do mesmo modo aqui o ritmo é diminuído com a introdução da conjunção "e":

il répétait à mes compères que les humains avaient fini par me faire perdre la raison, que j'allais droit vers la gueule du renard, que je risquais d'oublier nos habitudes, que j'allais m'éloigner de ce qui faisait de nous les animaux les plus nobles de la brousse, et notre vieillard de philosophe jura [...] (p. 50) repetia aos meus compadres que os humanos tinham feito com que eu perdesse a razão, que eu ia direto para a boca da raposa, que corria o risco de esquecer os nossos hábitos, que iria me afastar daquilo que fazia com que fôssemos os animais mais nobres da savana, e o nosso velho filósofo jurou [...] 
De maneira geral, e principalmente nos exemplos aqui citados, as repetições são verbais, por vezes precedidas de alguma outra estrutura que reforça ainda mais o argumento do narrador. Note-se que, com exceção do primeiro trecho, todos os outros mostram a repetição verbal e estrutural em cenas em que o narrador relata um acontecimento ou uma opinião que não é compartilhada por todos, que provoca dúvida ou desconfiança, seja no leitor, no próprio narrador ou em outras personagens: a existência de fantasmas, a existência de Jesus e a certeza de que o narrador porcoespinho iria se esquecer de sua comunidade animal. Assim, elencar verbos e estruturas, produzindo um ritmo mais contundente, é uma forma estilística de enfatizar essa dúvida, essa desconfiança, transmitindo a ironia do discurso do narrador.

Sobre a repetição de interjeições, o exemplo mais marcante é o da interjeição "hein", que é claramente usada em substituição do sinal de interrogação, como vimos em diversos trechos. Seu uso, sempre no final da oração, é responsável por uma breve pausa na trama, interrompendo o discurso e dando a possibilidade de respiração ao suposto contador de histórias.

No caso das outras interjeições, não há repetições enfáticas, mas um uso moderado que dialoga com o conteúdo narrado, como forma de ilustrá-lo ou reforçá-lo. Explicamos: acreditamos que intercalar a narração com uma interjeição é uma maneira de, primeiramente, remeter ao gestual próprio do discurso tête-à-tête e, em segundo lugar, pausar e suspender o desenrolar da história. Essa pausa, no entanto, está intimamente ligada ao que está sendo contado, conforme se vê nos dois exemplos selecionados:

1) Eh hop [e opa]: é uma interjeição que aparece uma única vez, na história de Amêdê, e procuramos em português por uma expressão que carregasse também o significado de surpresa, e que fosse informal e bastante corrente. Optamos pelo "opa", que tem também três letras e praticamente o mesmo som que "hop". A interjeição, nesse caso, aparece na cena em que Amedée tropeça, então a pausa causada pela intercalação é também a pausa causada pelo tropeço: 
alors Amédée se disait qu'il était beau, très beau, et un jour il avait failli se noyer car, afin de mieux contempler sa silhouette entière, il avait posé ses pieds sur une pierre recouverte de mousse, et hop, nom d'un porc-épic, il trébucha, se retrouva dans l'eau (p. 153) então Amêdê pensava que era bonito, muito bonito, e um dia ele quase se afogou pois, a fim de melhor contemplar a sua silhueta inteira, tinha posto os pés sobre uma pedra recoberta de musgo, e opa, palavra de porcoespinho, tropeçou, acabou na água

2) Et paf [e pá]: aparece apenas duas vezes, em situações em que o porco-espinho arremessa um de seus espinhos. A interjeição representa o barulho do espinho sendo lançado e atingindo, ou não, seu alvo. A pausa, aqui, remete à pausa real entre o momento em que os espinhos são lançados e o momento em que atingem seu alvo. Tentamos, na tradução, encontrar uma interjeição semelhante sonoramente e que remetesse ao barulho de coisas sendo atiradas, jogadas. A expressão "pá" não é super usual, porém acreditamos que transmite a ideia necessária.

j'étais à présent entre les jambes écartées d'Amédée, je me suis contracté pour choisir le piquant le plus ferme parmi les dizaines de milliers qui voulaient tous m'être utiles à cet instant, et paf, j'ai lancé la charge qui a échoué en plein milieu de la nuque du jeune homme (p. 165) estava agora entre as pernas abertas de Amêdê, me contraí para escolher o espinho mais firme dentre as dezenas de milhares que queriam todos me ser úteis nesse instante, e pá, lancei a carga que aterrissou bem no meio da nuca do jovem homem

Em relação à supressão ou contração sintática, ela se refere sobretudo ao caso dos pronomes, que seriam outro elemento a ser observado. Primeiramente, vale ressaltar que em francês o uso do pronome sujeito é sempre necessário, enquanto em português ele é comumente omitido, identificando-se o sujeito a partir da flexão verbal. Logo, pensamos que seria pouco natural mantê-los sempre, dando ares de redundância desnecessária à tradução. A título de exemplo, podemos citar esta passagem, na qual o pronome "je" aparece 8 vezes e, na tradução, se reduz a 3 (sendo uma repetida devido ao efeito pleonástico): 
à vrai dire, je n'ai rien à envier aux hommes, je me moque de leur prétendue intelligence puisque j'ai moi-même été pendant longtemps le double de l'homme qu'on appelait Kibandi et qui est mort avant-hier, moi je me terrais la plupart du temps non loin du village, je ne rejoignais cet homme que tard dans la nuit lorsque je devais exécuter les missions précises qu'il me confiait, je suis conscient des représailles que j'aurais subies de sa part s'il m'avait entendu de son vivant me confesser comme maintenant (p. 12) para dizer a verdade, não invejo os homens, tiro sarro da pretendida inteligência deles já que eu mesmo fui durante muito tempo o duplo do homem que chamávamos Kibandí e que morreu anteontem, eu, eu me enterrava a maior parte do tempo não longe do vilarejo, só me juntava a esse homem tarde da noite quando tinha que executar as missões precisas que ele me confiava, tenho consciência das represálias que ele me teria feito se tivesse escutado enquanto vivo eu me confessar como agora

Entretanto, manteve-se o pronome quando a frase ficaria ambígua sem ele ou quando é usado com efeito pleonástico. Sobre isso, são vários os casos. Algumas vezes foi viável, em português, a repetição do pronome para o mesmo efeito de ênfase, como podemos ver nos três exemplos a seguir, com a ressalva de que nos foi necessário, no primeiro e último trechos, fazer mudanças na ordem ou na pontuação da oração, por motivo estilístico e sonoro:

\begin{tabular}{|l|l|}
\hline $\begin{array}{l}\text { “moi je suis l'Hirondelle en question, et } \\
\text { vous, vous êtes ces petits oiseaux } \\
\text { inconscients" (p. 67) }\end{array}$ & $\begin{array}{l}\text { "eu, eu sou a andorinha em questão, e vocês, } \\
\text { vocês são esses pequenos passarinhos } \\
\text { inconscientes" }\end{array}$ \\
\hline $\begin{array}{l}\text { "mon dieu, tu en a vraiment, toi, je te dis } \\
\text { qu'avec ça tu es bien parti pour la vie" (p. } \\
118)\end{array}$ & $\begin{array}{l}\text { "meu deus, você é bem dotado, você, lhe digo } \\
\text { que com isso você começou bem a vida" }\end{array}$ \\
\hline $\begin{array}{l}\text { mon maître arrêta de travailler, lui aussi } \\
\text { (p. 125) }\end{array}$ & o meu mestre, ele também parou de trabalhar \\
\hline
\end{tabular}

Noutras vezes, não pareceu cabível a repetição pronominal para efeito pleonástico, e então se buscou outras soluções que pudessem, também, causar esse efeito. Dois exemplos significativos seriam: 


\begin{tabular}{|l|l|}
\hline $\begin{array}{l}\text { ce n'est pas comme ce que j'ai constaté dans } \\
\text { notre monde à nous (p. 127) }\end{array}$ & $\begin{array}{l}\text { não é como o que constatei nesse nosso } \\
\text { mundo }\end{array}$ \\
\hline $\begin{array}{l}\text { elle me voyait, elle, et moi je ne pouvais la } \\
\text { dintinguer (p. 184) }\end{array}$ & $\begin{array}{l}\text { ela mesma me via, e eu, eu não podia } \\
\text { distingui-la }\end{array}$ \\
\hline
\end{tabular}

No primeiro trecho o acréscimo do pronome demonstrativo "nesse", que já indicaria que é do mundo no qual estamos de que se fala, serve para enfatizar o pronome possessivo "nosso", causando o efeito de redundância - além de provocar uma bela sonoridade com as assonâncias em "s" e "n". No segundo exemplo, "ela mesma" é também redundante, e substitui a repetição do pronome sujeito, que em português é pouco usual.

Em relação ao pronome sujeito "on", a tradução variou de acordo com o contexto. Em francês, ele pode designar tanto "a gente", de uso informal, quanto um plural indeterminado, impessoal, ou um coletivo com valor universal, sendo em português normalmente seguido da partícula "se". Quando, segundo nossa leitura, o narrador se incluía no relato como sujeito observador, optamos pela primeira pessoa do plural; quando ele estava apenas relatando rumores, especulações ou verdades gerais, usamos o impessoal com a partícula "se" ou a terceira pessoa - esses casos foram mais abundantes. Alguns exemplos são:

[...] courent dans tout le village, aiment jouer près du cimetière, dans un vaste champ de lantanas où ils déplacent les croix des tombes, les intervertissent, jouent à cache-cache, traquent sans répit les papillons, épouvantent les corbeaux, mènent la vie dure aux moineaux à l'aide de leurs redoutables lancepierres, on ne peut pas les contrôler, ils sont toujours là où on ne les attend pas (p.195196) [...]correm por todo o vilarejo, adoram brincar perto do cemitério, numa vasta plantação de lantanas onde eles mudam as cruzes dos túmulos, as invertem, brincam de escondeesconde, perseguem sem pausa as borboletas, espantam os corvos, deixam a vida dura aos pardais com a ajuda dos seus temíveis estilingues, não se pode controlá-los, estão sempre lá onde não os esperam 
Nesse trecho o narrador está apresentando os terríveis gêmeos Koty e Kotê, dois pestinhas. Ao dizer que "on ne peut pas les contrôler", entendemos que o porco-espinho não se inclui no sujeito plural, já que não tem nenhuma proximidade com as crianças, muito pelo contrário, mal as conhece. Assim, concluímos que seria o caso de usar a terceira pessoa, indeterminando o sujeito e exprimindo generalidade. $\mathrm{O}$ mesmo ocorre no trecho seguinte, quando o narrador relata a volta do feiticeiro Tembê-Essuká ao vilarejo. Nesse caso, o uso da terceira pessoa do singular se deu por se tratar de uma narração distanciada sobre a opinião dos moradores do vilarejo, com caráter de especulação, como aparece no próprio texto na palavra "especulações" e no verbo “dizia-se", que exprime uma suposição:

le sorcier avait une nouvelle à annoncer, les spéculations se multiplièrent, on se demanda surtout comment cet aveugle avait pu s'orienter seul dans la brousse, et puis on se disait qu'en réalité sa cécité était une parade puisqu'il pouvait tout voir (p.104) o feiticeiro tinha uma novidade para anunciar, as especulações se multiplicaram, perguntava-se sobretudo como esse cego tinha podido se orientar sozinho na savana, e depois dizia-se que na realidade a sua cegueira era uma ostentação já que ele podia tudo ver

No próximo trecho, o porco-espinho conta sobre sua primeira missão, “comer" a jovem Kiminú, filha de Papai Lubotô, que aceitou de bom grado todos os presentes e ajudas de Kibandí e mesmo assim não lhe concedeu a mão de sua filha. Kibandí, enraivecido, resolve se vingar e matá-lo. Nessa passagem, o narrador está detalhando as benfeitorias que Kibandí havia feito ao velho Lubotô, e entendemos aqui que o "on" inclui o narrador, personagem ativa nessa parte da história:

[Kibandí] avait aussi refait la toiture de cet homme sans lui demander un sou, et on pouvait lire dans le regard de Papa Louboto une espèce d'attente inextinguible (p.138)
[Kibandí] tinha também refeito o telhado desse homem sem lhe cobrar um centavo, e podíamos ler no olhar de Papai Lubotô uma espécie de espera inextinguível 
No que se refere aos possessivos, usamos a mesma lógica dos pronomes sujeito. Em português, soaria redundante e forçado repetir alguns possessivos, principalmente os de terceira pessoa do plural. O intuito foi, portanto, manter a fluência do texto. Por exemplo, no trecho:

Koty et Koté sont arrivés, les habits couverts de poussière, ils n'ont jeté qu'un regard expéditif vers leur père et son visiteur (p.202)
Koty e Kotê chegaram, as roupas cobertas de poeira, apenas deram um olhar apressado para o pai e seu visitante

Suprimimos também outros termos que costumam ser redundantes em português, sobretudo em orações em que havia enumeração de ações, já que em língua portuguesa é possível deduzir que a partícula suprimida está oculta. Apesar de nesses casos acabarmos com o efeito de paralelismo causado pela repetição, o objetivo foi dar mais fluidez e naturalidade ao relato. Além do mais, a redução sintática acelera a tensão da oração. Dois exemplos, o primeiro com omissão do pronome complemento de objeto direto e o segundo com omissão verbal e do pronome reflexivo, seriam:

en fait, j'ai beau me forcer, je n'ai pas d'appétit, pourtant il faut que je mange, toutes ces noix de palme n'ont plus le goût $d$ 'autrefois, je les brasse encore, je les scrute, je les renifle (p.215)

eh bien allons-y, laisse-moi me remettre sur mes pattes, laisse-moi me recroqueviller, laisse-moi me concentrer (p.221) na verdade, eu me forcei bastante, não tenho apetite, no entanto é preciso comer, todas essas nozes de palma não têm mais o gosto de antes, eu ainda as amadureço, estudo, farejo

pois bem vamos lá, me deixe levantar, encolher, concentrar 
Em relação à colocação pronominal, vale ressaltar que as regras no português escrito não são normalmente seguidas no português oral, e além disso em francês o uso dos pronomes complemento de objeto é corriqueiro e, por isso, não tem a conotação formal que pode ter em português. Na busca por recriar a ambientação do relato informal e espontâneo do narrador, optamos, na maior parte das vezes, por deixar o pronome antes do verbo ou omiti-lo, como é o caso dos exemplos supracitados. Algumas vezes, no entanto, seguimos a regra de ênclise do português, por julgarmos se tratar de um relato espontâneo, mas não em desavença com as normas gramaticais.

Contrário à supressão, noutras passagens nos foi necessário acrescentar termos à oração. Dois exemplos seriam:

\begin{tabular}{|l|l|}
\hline $\begin{array}{l}\text { Youla ne méritait pas d'être un père, lui } \\
\text { l'alcoolique, lui qui n'honorait pas ses } \\
\text { engagements, lui qui devait peut-être de } \\
\text { l'argent à toute la population (p.179) }\end{array}$ & $\begin{array}{l}\text { Yulá não merecia ser pai, ele que era } \\
\text { alcoólatra, ele que não honrava os seus } \\
\text { compromissos, ele que talvez devesse } \\
\text { dinheiro a toda a população }\end{array}$ \\
\hline $\begin{array}{l}\text { "vos jumeaux viennent me déranger depuis } \\
\text { plus de deux semaines, ils sont encore venus } \\
\text { me provoquer en début d'après-midi" } \\
\text { (p.201) }\end{array}$ & $\begin{array}{l}\text { "os seus gêmeos vêm me incomodar há mais } \\
\text { de duas semanas, eles vieram me provocar } \\
\text { também hoje no começo da tarde" }\end{array}$ \\
\hline
\end{tabular}

É interessante notar que, no primeiro trecho, acrescentamos um verbo, que nos pareceu necessário para a construção sintática da mensagem em português, e isso possibilitou dar continuidade ao paralelismo já existente nas orações seguintes, todas começando com "lui que + verbo". Outra possibilidade poderia ter sido inserir uma vírgula - "ele, alcoólatra" - mas, nesse caso, perderíamos o paralelismo e a ênfase da repetição. No segundo exemplo, optamos por enfatizar o tempo presente da enunciação com o acréscimo do advérbio "hoje". 
Ainda sobre os pronomes, outro dilema tradutório foi - e pensamos ser um dilema frequente entre os tradutores - , a escolha entre o tu/você e vocês/o(a) senhor(a)/vós. Em francês, distingue-se claramente o "tu", designando a segunda pessoa do singular, do "vous", destinado à segunda pessoa do plural ou ao tratamento formal, que nesse caso pode referir-se ao singular. Pensando na aproximação sonora, poderíamos traduzir o "tu" francês pelo "tu" português, desconsiderando o uso do "você". Da mesma maneira, poderíamos traduzir "vous" por "vós", assim como seus respectivos pronomes possessivos e oblíquos átonos. No entanto, o uso do "tu" em português se limita ao extremo sul do país e alguns pontos do norte, tendo sido substituído por "você" no restante do território. "Você", por sua vez, é usado de maneira informal, como forma de intimidade, mas também como "tratamento de igual para igual ou de superior para inferior" (CUNHA, 2008, p. 306). As formas oblíquas (te, ti, contigo), no entanto, são usadas com maior frequência. Já o pronome "vós" caiu em desuso tanto em Portugal quanto no Brasil. Pode ser usado com caráter enfático, para um auditório qualificado, ou em referência a uma só pessoa, como tratamento de cerimônia, nesse caso sendo marca de um português antigo e clássico, ou "em linguagem literária de tom arcaizante" (Ibid., p. 299).

Ora, o tom de $M P E$ não parece ser nada antigo, clássico, cerimonioso ou arcaico, o que nos faz crer que a opção pelo tu/vós não se encaixa. Em decorrência, ficamos com o "você/o senhor". Porém, como distinguir o uso do "vous" plural, em francês, uma vez que pode ser usado tanto como marca de formalidade e distanciamento quanto como marca de plural informal? É claro que o contexto esclarece a maior parte das dúvidas, mas há casos em que a fala se dirige a várias pessoas, mas não se sabe se o tratamento é formal ou informal, ou seja, se usaríamos, na tradução, "os senhores" ou "vocês". 
Aqui entra a subjetividade do tradutor, mais uma vez (e sempre) interpretando as passagens em que aparece o pronome da terceira pessoa do plural, julgando seu emprego de acordo com a leitura que fez do trecho e seu contexto. Por conseguinte, optamos por "vocês" como forma de enfatizar a insubordinação, falta de respeito ou hierarquia entre as personagens, assim como o "senhor" para enfatizar o respeito. Por exemplo, na já comentada passagem em que Tia Etalelí vai visitar o feiticeiro TembêEssuká, traduziu-se o "vous" falado pelo ancião por "vocês", quando se dirigia ao grupo todo, mas por "a senhora", quando se dirigia apenas à tia. Nessa cena, a tia é a personagem central da história, sendo os outros acompanhantes meros coadjuvantes. Logo, o feiticeiro mantém certo respeito quando fala com ela, a responsável pela visita, mas se distancia e marca sua superioridade quando fala com o grupo como um todo. Por outro lado, a tia sempre se dirige ao feiticeiro por "o senhor", marcando respeito e reverência.

Já na passagem em que Kibandí discute com os gêmeos Koty e Kotê, estes se dirigem a ele, um adulto desconhecido, por “o senhor", enquanto Kibandí se dirige às crianças por "vocês":

"qu'est-ce que vous me voulez, hein", a fini par dire Kibandi, un de deux petits Moundjoula a répondu, "vous êtes un méchant, c'est pour ça que vous n'aimez pas les enfants" (p.198-199) "o que é que vocês querem de mim, hein", acabou por dizer Kibandí, um dos dois pequenos Mundjulá respondeu "o senhor é um malvado, é por isso que não gosta das crianças"

Note-se que a tradução deste último trecho exclui o último pronome "vous", que vimos ser em português dispensável. Como as duas formas de tratamento — "você" e “o senhor" - são conjugadas na terceira pessoa, nem sempre é possível definir a formalidade e, ao mesmo tempo, deixar o texto fluido, natural. Isso posto, há momentos em que a marca do "vous" de formalidade desaparece na tradução. Outro exemplo poderia ser o momento em que o narrador explica a morte de Luvunú, um homem que notou um porco-espinho estranho rondando a cabana de Kibandí e relatou o ocorrido ao chefe do vilarejo. A omissão da marca de formalidade e dos pronomes ocorreu, 
sobretudo, junto ao verbo "jurar", utilizado muitas vezes pelo narrador na busca de cumplicidade com a árvore. Em português, é muito comum usarmos "juro", nesse sentido, sem nenhum outro complemento. Eis a passagem:

"d'un côté c'était comme un porc-épic, je vous dis, et de l'autre, c'est bizarre, c'était même pas comme un porc-épic, je veux dire, c'était un animal étrange, il m'a regardé comme un homme pourrait regarder un autre homme, et il m'a montré son derrière avant de disparaître dans l'atelier du charpentier, je vous jure que je n'ai pas rêvé, croyez-moi" (p.189-190) "por um lado era como um porco-espinho, lhe digo, e por outro, é bizarro, nem era como um porco-espinho, quero dizer, era um animal estranho, me olhou como um homem poderia olhar um outro homem, e me mostrou o seu traseiro antes de desaparecer no ateliê do carpinteiro, juro que não sonhei, acredite em mim"

A polêmica sobre o uso dos pronomes pessoais diz respeito, por fim, ao tipo de registro da narrativa, que seria outro elemento "obsessivo". Conforme vimos, a narrativa inteira é direcionada à árvore em tom confessional, informal, remetendo à contação de histórias. Consequentemente, os elementos informais comuns no discurso oral já foram bastante discutidos aqui, em quase todos os tópicos deste último capítulo. Agora, no entanto, gostaríamos de frisar três elementos sintáticos próprios ao registro oral, que se sobressaem principalmente nos trechos de discurso direto, enfatizando o caráter informal dos diálogos. São eles: o uso do advérbio "là"; a negação sem a partícula "ne"; a contração do pronome demonstrativo "cela".

No que concerne à contração do pronome "cela" — "ça" —, que em português não existe, a traduzimos por "assim", quando precedida pelo "comme" [como], e por "isso" quando aparece sozinha. Da mesma forma, o advérbio "là", que tem o significado primeiro de "aqui", é usado no romance como forma de enfatizar ou precisar o que está sendo dito, marcando o momento presente da enunciação. Em português, podemos usar “aqui” com essa mesma função, mas nem sempre isso funciona. Há casos, portanto, em que buscamos outras estratégias na tentativa de enfatizar esse aspecto oral. Assim, possíveis traduções de "là" são "agora”, “aqui”, “aí”, dependendo do contexto. Vejamos alguns exemplos: 


\begin{tabular}{|l|l|}
\hline $\begin{array}{l}\text { “si c'est comme ça, je ne vous dirai plus } \\
\text { rien” (p. 49) }\end{array}$ & "se é assim, não lhes direi mais nada” \\
\hline $\begin{array}{l}\text { sinon je ne serais pas là à te parler de tout ça } \\
\text { (p. 52) }\end{array}$ & $\begin{array}{l}\text { senão não estaria aqui para lhe contar tudo } \\
\text { isso }\end{array}$ \\
\hline $\begin{array}{l}\text { je voudrais bien t'aider à retrouver les tiens, } \\
\text { mais je suis pressé là où tu me vois là (p. } \\
75)\end{array}$ & $\begin{array}{l}\text { eu queria mesmo lhe ajudar a reencontrar os } \\
\text { seus, mas estou com pressa agora como você } \\
\text { pode ver aqui }\end{array}$ \\
\hline $\begin{array}{l}\text { "vous, là, qu'est-ce que vous venez faire } \\
\text { chez moi comme ça, hein" (p. 96) }\end{array}$ & $\begin{array}{l}\text { "vocês, aí, o que é que vêm fazer na minha } \\
\text { casa assim, hein” }\end{array}$ \\
\hline
\end{tabular}

Em relação à negação sem o "ne", que também não faz sentido em português, já que a estrutura da negação apresenta apenas uma partícula, optamos por fazer o contrário, acrescentando um "não" a mais na oração, além de mudarmos o "não" para "num", como por vezes acontece no discurso oral informal. Outras vezes mantivemos a negação padrão do português, perdendo a informalidade transmitida no original privilegiamos, nesses casos, a prosódia da língua portuguesa. Três exemplos seriam:

\begin{tabular}{|l|l|}
\hline $\begin{array}{l}\text { “Tembé-Essouka, la mort de ma fille n'est pas } \\
\text { une mort normale, c'est pas comme ça qu'une } \\
\text { personne doit mourir" (p. 97) }\end{array}$ & $\begin{array}{l}\text { "Tembê-Essuká, a morte da minha filha } \\
\text { num é uma morte normal não, num é assim } \\
\text { que uma pessoa deve morrer" }\end{array}$ \\
\hline $\begin{array}{l}\text { "tes trucs que tu fais dans ce village avec celui } \\
\text { qui t'a envoyé ici, c'est pas à moi que tu les } \\
\text { feras" (p. 184) }\end{array}$ & $\begin{array}{l}\text { "os trecos que você faz neste vilarejo junto } \\
\text { àquele que o enviou aqui, num é a mim não } \\
\text { que os fará” }\end{array}$ \\
\hline $\begin{array}{l}\text { "si t'es pas d'accord, t'as qu'à aller recueillir } \\
\text { le mwengué toi-même, ou alors tu paies le prix } \\
\text { que je veux, point barre" (p. 170) }\end{array}$ & $\begin{array}{l}\text { "se num tá de acordo, é só ir pegar o } \\
\text { mwenguê você mesmo, ou então você paga } \\
\text { o preço que eu quero, ponto final” }\end{array}$ \\
\hline
\end{tabular}

A escolha por uma tradução mais informal, nesses trechos, ocorreu para marcar, propositalmente, a atmosfera da fala, raivosa, irritada ou angustiada. Pensamos, ao usar esse registro, conseguir transmitir a falta de paciência dos personagens em cada uma das cenas. 
Outro pequeno comentário gramatical relacionado ao registro informal é a escolha de traduzir o verbo "avoir" por "ter", e não "haver", normalmente usado em discursos mais formais. Exemplos disso seriam:

j'ai aussitôt contenu cet état parce qu'il y a des gens qui sont morts de rire dans ce village (p.42)

il racontait que mês procréateurs étaient aussi têtus que moi, qu'ils avaient quitté cette terre quelque temps après ma venue au monde (p.55) imediatamente contive esse estado porque tem gente que morre de rir neste vilarejo teimosos quanto eu, que eles tinham abandonado essa terra algum tempo depois de minha vinda ao mundo

Por fim, o último elemento que acreditamos fazer parte da construção do padrão rítmico dessa narrativa de Mabanckou são os enunciados proverbiais, ou, conforme explicamos no subitem semântico, as chamadas paremias. Note-se que, de fato, elas condensam muitas das características supracitadas (contração ou acréscimo de palavras, uso dos pronomes, repetições estruturais etc.). Segundo Silva (2006, p.18), o que diferencia as paremias das outras unidades fraseológicas é "o seu valor de verdade geral e seu caráter folclórico, etnológico, antropológico e anônimo" e, com isso, "o locutor se distancia do seu enunciado, desligando-se de toda responsabilidade sobre o dito" (Idem).

Vimos no Capítulo 2 que os enunciados considerados proverbiais no romance têm justamente essa característica de paremia, pois servem para fundamentar a palavra da personagem, na medida em que ela se distancia de seu argumento e emprega um dito de valor universal, mais convincente. Conforme expusemos no início deste capítulo, acreditamos ser interessante adotar uma abordagem de viés não etnocêntrico na tradução das paremias, assim como dos sintagmas fraseológicos, traduzindo não apenas palavra por palavra do provérbio, mas também "o seu ritmo, o seu comprimento (ou sua concisão), suas eventuais aliterações etc.” (BERMAN, 2007, p.16), ${ }^{151}$ que seriam perdidas e substituídas por outras imagens caso optássemos por uma tradução por

\footnotetext{
${ }^{151}$ Parte desta análise sobre as unidades proverbiais foi previamente publicada no artigo "A tradução de provérbios em Alain Mabanckou", Revista Non Plus, n.7, 2015, p.54-66.
} 
equivalência. Esta eliminaria provavelmente mais aspectos formais e até mesmo semânticos do provérbio original em prol de manter a "forma-provérbio", como diz Berman (Idem).

Ao optar pela tradução "literal", portanto, atentamos para o "jogo dos significantes", criando um enunciado que muitas vezes não corresponde a um provérbio existente na língua de chegada, mas que retoma a prosódia, as imagens, o ritmo do original, causando a "estranheza do estrangeiro", tirando o leitor de sua zona de conforto e levando-o até o autor. Nas palavras de Berman (Ibid., p.17, grifos do autor):

Pois procurar equivalentes, não significa apenas estabelecer um sentido invariante, uma idealidade que se expressaria nos diferentes provérbios de língua a língua. Significa recusar introduzir na língua para a qual se traduz a estranheza do provérbio original. [...] Para o tradutor formado nesta escola, a tradução é uma transmissão de sentido que, ao mesmo tempo, deve tornar este sentido mais claro, limpá-lo das obscuridades inerentes à estranheza da língua estrangeira.

Há quem argumente que adotar uma estratégia de viés não etnocêntrico, no caso do provérbio, o descaracterizaria, quer dizer, o leitor não reconheceria o enunciado como um provérbio e este perderia seu valor proverbial dentro do texto. Esse argumento pode ser refutado se pensarmos que todos nós, independente de nossa língua-cultura, possuímos o que Berman chama de "consciência-de-provérbio" (Ibid., p.60), quer dizer, somo capazes de perceber estruturas que, quando lidas em determinado contexto, nos remetem imediatamente a eles.

Pudemos observar algumas das características elencadas no Capítulo 2 sobre as estruturas proverbiais ao longo do romance, que conta com 21 enunciados advindos do imaginário africano e, também, de outras culturas. Percebe-se que eles têm importância central na construção narrativa, uma vez que discorremos sobre eles tanto na esfera macro quanto na microestrutural. As imagens neles contidas, principalmente nos que aparecem nas duas primeiras partes, são fortemente relacionadas ao mundo animal e, nesse sentido, a tradução por equivalência seria prejudicial à ambientação animalesca e à iconicidade dos enunciados.

Percebemos, ao longo da tradução, que os comentários tradutórios a respeito deles foram mais gramaticais, relacionando-se à esfera microestrutural. Pensamos que, 
talvez, isso se deva ao fato de não termos encontrado provérbios equivalentes em língua portuguesa, o que impossibilitou uma reflexão sobre o uso ou não da equivalência, já que nos restou apenas a opção de traduzi-los "literalmente", contando com a sorte de suas metáforas serem transparentes, de fácil entendimento. Comentamos pontualmente alguns deles:

\begin{tabular}{|c|c|}
\hline Original & Tradução \\
\hline $\begin{array}{c}\text { si tu veux que Dieu se marre, raconte-lui } \\
\text { tes projets (p. 24) }\end{array}$ & $\begin{array}{c}\text { se você quer que Deus se divirta, conte a ele } \\
\text { os seus projetos }\end{array}$ \\
\hline
\end{tabular}

Comentário: As escolhas que preponderaram neste provérbio foram referentes à sonoridade lexical. Temos em francês o verbo "se marrer", que em português poderia ser traduzido por "rir", mas optamos por um verbo também pronominal, "se divertir", assim como "projets" ficou "projetos", de tradução transparente. No entanto, "raconte-lui", que poderia ser traduzido por "conte-lhe", seguindo a mesma estrutura, ficou "conte a ele", que é informal e condiz mais com o contexto do livro.

quand on coupe les oreilles, le cou devrait s'inquiéter (p. 29) quando se cortam as orelhas, o pescoço deveria se preocupar

Comentário: Traduziu-se o "on" pelo coletivo impessoal, pois essa construção é comumente usada em português quando se quer transmitir uma verdade universal, um valor total, e mantém a ideia proverbial. Devido a isso, foi necessário acrescentar a partícula "se", inexistente no original, à tradução. Para manter o paralelismo com o último verbo, deixamos o "se" antecedendo o verbo.

quand le sage montre la lune, l'imbécile regarde toujours le doigt (p. 49-50) quando o sábio mostra a lua, o imbecil olha sempre para o dedo

Comentário: Uma rápida pesquisa na internet nos fez encontrar traduções para o português com pequenas variações entre si, referentes ao léxico "lune". Aparentemente é um provérbio chinês. A estrutura em todos os casos que encontramos é: "quando o sábio aponta para a lua/ estrelas/ céu, o idiota olha para o dedo". Pensamos, entretanto, que aproximação sonora do verbo "montrer" com o verbo "mostrar" é mais interessante do que a precisão de seu significado, que se aproximaria mais de "apontar". Da mesma forma, mantivemos o léxico "lua" e "imbecil", conforme o original, ao invés de nos aproximarmos da versão encontrada e disseminada na internet. 
le tambour est fait de la peau du faon qui s'est éloigné de sa mère (p. 52) o tambor é feito da pele do veadinho que se afastou da sua mãe

Comentário: "faon" é o nome dado em francês para o filhote do veado. Não existe tal palavra em português, então poderíamos optar por "filhote do veado", que aumentaria demais o comprimento da oração, ou "veadinho". Apesar de "veadinho" remeter a um sentido pejorativo relacionado à inclinação sexual, sentido este que não está claro no provérbio original, a sequência da passagem pode relacionar-se a isso, logo achamos cabível nesse contexto. Na continuação, lemos: "aliás tinham começado a me azucrinar me chamado de "veadinho" até o dia em que, irritado pelas piadas que não me faziam mais rir nadinha, eu lhes expliquei que veadinho era o filhote de uma fera, de um veado, de um gamo ou de um cervo, ora eu, eu era um porco-espinho, um porco-espinho orgulhoso de sê-lo" [ils avaient d'ailleurs commencé à me charrier en m'appelant 'le faon' jusqu'au jour où, agacé par ces blagues qui ne me faisaient plus du tout rire, je leur avais expliqué que le faon était le petit d'une bête fauve, d'un cerf, d'un daim ou d'un chevreuil, or moi j'étais un porc-épic, un porc-épic fier de l'être]

assieds-toi au pied d'un baobab et, avec le temps, tu verras l'Univers defiler devant toi”' (p. 149) senta-te ao pé de um baobá e, com o tempo, verás o Universo desfilar diante de ti

Comentário: Este provérbio apresenta a particularidade de ter sido traduzido para a segunda pessoa do singular, "tu", sendo que no restante do livro traduzimos a segunda pessoa em francês (tu) pela terceira pessoa do português (você), conforme vimos. Ainda que pareça incongruente deixar apenas um enunciado com o pronome na segunda pessoa, acreditamos que, nesse caso específico, usar o "tu" - forma antiga, clássica e que caiu em desuso no Brasil - pode levar o leitor à atmosfera que o provérbio propõe, já que fala sobre o poder do baobá, árvore milenar, e sobre o passar do tempo. Além disso, a própria concepção de provérbio remete a um enunciado tido como "universal", "fixo", o que pode levar a ideia de algo antigo, elaborado em tempos remotos. Não podemos deixar de pensar, também, na questão sonora. No original temos a rima assieds-toi/ baobab/ veras/ toi. Na tradução, optando pelo uso da segunda pessoa, conseguimos a assonância em " $\mathrm{t}$ ", assim como no original, além de rimar o começo com o final [senta-te/diante de ti] (pensando na pronúncia do português, em que "te" é dito como "ti"), e "baobá" com "verás", ainda que não perfeitamente. Isso se perderia se traduzíssemos por "sente-se" e "diante de você", que além do mais altera o comprimento do enunciado.

à chaque jour suffit sa peine (p. 217)

a cada dia basta sua pena

Comentário: Na pesquisa feita por Xatara, encontramos a equivalência deste provérbio para o português (provérbio n. 345): "A cada dia dá Deus sua dor e alegria" (XATARA, 2002, p. 31). Uma pesquisa rápida no google ainda nos dá outras opções como "cada dia traz sua alegria e sua pena"/ "a cada dia suas penas" / "cada dia com suas penas". Aqui novamente optamos pelo distanciamento das versões conhecidas em português, todas mais compridas e 
com acréscimos, para nos atentarmos à sintaxe e cadência do original. 


\section{Conclusão}

Para que a tradução de Mémoires de porc-épic ganhasse forma, percorremos um longo caminho, que nos permitiu aprofundar nossos conhecimentos sobre o autor e sua obra. É evidente que o trajeto escolhido não é único, mas sim um entre muitos outros, baseado na nossa inclinação tradutória pessoal, na nossa leitura do texto e no nosso entendimento de mundo. Isso posto, as possibilidades de interpretação e de tradução proporcionadas a partir da escolha desse caminho convergiram para que entendêssemos o "ritmo congolês" de que fala Mabanckou e, por conseguinte, adotássemos uma postura tradutória que visasse retomar e recriar esse ritmo na língua portuguesa.

Assim, a partir da análise sintática e semântica do romance, descobrimos que o ritmo da prosa de $M P E$ relaciona-se diretamente ao ritmo próprio à contação de histórias, que por sua vez faz parte das referências pessoais do autor, bem como outros elementos intertextuais concernentes a outras culturas também presentes na construção narrativa do livro. Levando em conta a discussão inicial sobre identidade-rizoma e abertura ao Outro, foi possível notar que é por intermédio desse ritmo que Mabanckou dialoga com a alteridade no romance.

Isso pode ser percebido já no título: Memórias de porco-espinho revela, logo de saída, se tratar de uma narrativa fragmentada, no sentido de que as "memórias" são lembranças, e estas são, normalmente, pouco lineares, por vezes confusas, misturadas. Tal qual a estrutura de um rizoma, portanto, a narrativa do livro se constrói horizontalmente, não há nem um começo nem um fim estruturalmente determinados apesar de haver, é claro, um começo e um fim na leitura, inerentes ao formato "livro" , como se estivéssemos lendo uma parte de uma história muito maior, ainda inacabada, assim como é a vida, aliás. Isso é visto tanto no começo do relato, sendo a primeira palavra "donc" [então], quanto no final, sendo a última palavra a interjeição "hein". É como se o romance começasse com uma vírgula - retomando um discurso já iniciado — e terminasse com uma interrogação ao leitor, ou seja, uma abertura.

A vírgula, único sinal de pontuação do livro, marca o não fechamento de sentido, enfatizando também o aspecto de abertura, fornando uma espiral narrativa. Ao 
longo da leitura dessa espiral vamos conhecendo as personagens, suas histórias e angústias por meio das digressões e das interferências intertextuais, que são muitas. Entendemos que a estrutura do discurso do porco-espinho é movente, no sentido de que não segue a ordem cronológica dos fatos e não apresenta as personagens nem a história de maneira linear.

É assim que Mabanckou dialoga com a alteridade, uma vez que as digressões e a narrativa espiral fazem parte da composição do ritmo, em que se articulam um modo de narrar congolês num texto escrito em francês, no qual se mesclam línguas autóctones, referências a outros autores, provérbios e distintos registros de língua. Esse conjunto de elementos marca a relação da obra com a pluralidade de línguas e culturas existentes. $\mathrm{O}$ ritmo, ademais, aparece também na pontuação e nos seus desdobramentos para elementos como as repetições, os paralelimos, as interjeições. Essas características, chamadas aqui de microestruturais, podem ser percebidas em relação com a alteridade se pensarmos que se relacionam diretamente com a atmosfera oral e espontânea recriada pelo autor. Em outras palavras, ao instaurar o universo de contação de histórias como elemento central da narrativa, instaura-se, consequentemente, um diálogo implícito com o Outro.

Em vista disso, a tradução do romance nos permitiu percorrer, via anotações, um espinhoso caminho de entendimento da noção de ritmo em Mabanckou. Foi importante primeiramente esmiuçar os elementos macro e microestruturais, relacioná-los à oralidade própria das sociedades africanas e à visão de mundo do autor para, enfim, percebermos do que se tratava a tradução do ritmo do texto. Nossas descobertas, apresentadas nas anotações de tradução, giram em torno da concepção de que a "maneira de fluir" do texto de MPE, como diz Benveniste (1995, p.368), ou seja, o modo de narrar congolês, se conecta tanto ao léxico escolhido pelo autor quanto à sintaxe. Podemos relembrar a interação informal com a árvore/público/leitor, assim como dramaticidade gestual própria a um contador de histórias, ambas contribuindo para introduzir uma digressão, com esta passagem:

foi assim, meu querido Baobá, que eu saí do mundo animal a fim de me colocar a serviço do pequeno Kibandí que acabava de ser iniciado em Mossaká, esse pequeno que eu iria seguir bem mais tarde em Sêkêpembê, esse pequeno que eu não iria mais largar durante décadas até a sexta-feira passada quando não pude fazer nada para evitar a sua morte, ainda estou afetado, não queria que me visse aos prantos, vou 
então virar de costas para você por decência e respirar um pouco antes de prosseguir (p.76)

Igualmente, a abundância de provérbios insere a narrativa numa atmosfera de oralidade, intercalando momentos de narração com outros de digressão:

quando vi Kibandí soluçar, depois entregar a alma, fiquei na hora enlouquecido porque, como teria dito o nosso velho governante em seu tempo, "quando se cortam as orelhas, o pescoço deveria se preocupar”, e eu, eu já não sabia mais o que fazer, aonde ir, andava em círculos, o espaço parecia se reduzir a minha volta, eu temia que o céu caísse sobre mim, tinha a respiração cortada (p.29)

Quanto à sintaxe, relembramos uma passagem bastante rítmica, em que a insistência na enumeração é vista na repetição da estrutura da oração e da interjeição, o que colabora para acelerar o relato. A repetição de estruturas, usada principalmente para enumerar as pessoas assassinadas pelo narrador, constitui uma das principais "obsessões rítmicas" do texto, retomando Ana Cristina Cesar (1999, p.367) quando diz que "no ritmo sempre existe algo de obsessivo":

e o que dizer de Mabialá o carteiro que ele suspeitava estar dando voltas ao redor de Mamãe Kibandí, hein, e de Lubandá o fabricante de tam-tam de quem ele reprovava o sucesso com as mulheres, hein, e de Sengá o pedreiro que tinha recusado trabalhar para ele, hein, e de Dikamoná a corista das cerimônias fúnebres que não lhe dizia bom dia, ela que o tinha tratado de velho bruxo em público, hein, e de Lupialá a primeira enfermeira diplomada vinda de Mossaká (p.90-91)

Consequentemente, consideramos a abordagem de viés não etnocêntrico bastante apropriada à leitura e interpretação que fizemos do texto original, nos permitindo recriar, pelo menos em parte, em língua portuguesa, a ambientação imaginada por Mabanckou.

O trabalho de tradução nos permitiu, ainda, importante reflexão no que diz respeito à relação entre as línguas de que fala Glissant. Ao longo do processo, a tarefa de não perder de vista o Outro por meio de práticas, conscientes ou não, etnocêntricas, foi árdua, pois existem automatismos ou vícios que nos fazem, por vezes, distanciarmonos da proposta tradutória. Estar constantemente atento à relação com o Outro é estar atento à relação entre a nossa língua, o português, com a outra língua, o francês, mas também com todas as outras línguas. Tendo isso em vista, o trabalho de tradução a que nos propusemos se quer uma "arte da fuga de uma língua a outra, sem que, no entanto, a 
primeira se apague, e sem que a segunda renuncie a apresentar-se"152 (GLISSANT, 2005, p.56). Ainda segundo Glissant, a tradução seria "renúncia", que "constitui, na totalidade-mundo, a parte de si mesmo que se abandona, em toda e qualquer poética, ao outro" (Ibid., p.57). Dito de outra maneira, renunciamos à relação "tradicional" entre a língua de partida e a língua de chegada - aquela que busca equivalentes - para imaginarmos, criarmos uma nova relação entre essas duas línguas, o que entendemos ser, afinal, o trabalho criativo do tradutor.

Cabe lembrar, portanto, que, se a tradução não é e nunca será uma cópia do original, mas sim uma criação literária nova, original ela também, ela carrega em si a subjetividade e as escolhas do tradutor. Logo, este trabalho tem a intenção de ser um impulso inicial para que comecemos a falar de Alain Mabanckou no Brasil e no âmbito acadêmico, bem como da tradução de suas obras, e é evidente que outras traduções, em outras épocas e contextos, são possíveis e bem-vindas.

${ }^{152}$ Tradução de Enilce Albergaria Rocha. 


\section{Referências bibliográficas}

AZENHA, J. Transferência cultural em tradução: contextualização, desdobramentos, desafios. Tradterm, 16, p.37-66, 2010.

BASSNETT, S. Estudos de tradução: fundamentos de uma disciplina. Tradução de Vivina de Campos Figueiredo. Lisboa: Fundação Calouste Gulbenkian, 2003.

BERMAN, A. A tradução e a letra ou o albergue do longínquo. Tradução de MarieHelène Catherine Torres, Mauri Furlan, Andréia Guerini. Rio de Janeiro: 7 Letras, 2007.

BINTOU, B. A. Les africanismes dans la littérature d'Afrique noire francofone: d'un concept colonial à une esthétique littéraire. 2014. 390 f. Tese (Doutorado em Letras) - Faculté de Lettres, Université de Lausanne, Lausanne, 2014. Disponível em: $<$ https://serval.unil.ch/resource/serval:BIB_235139EDB4F7.P001/REF >. Acesso em: 12 out. 2016.

BENVENISTE, E. "A noção de 'ritmo' na sua expressão linguística”. Tradução de Maria da Glória Novak e Maria Luisa Neri. In: Problemas de linguística geral I. Campinas: Pontes, 1995.

BORDAS, E. Le rythme de la prose. Rhuthmos. 12 de novembro de 2012. Disponível em : < http://rhuthmos.eu/spip.php?article749 >. Acesso em: 22 ago. 14.

CALVET, J-L.; CALVET, A. Les confettis de Babel. Diversité linguistique et politiques des langues. Paris: Ecriture, 2013.

CAUVIN, J. Comprendre les proverbes. Paris: Ed. Saint-Paul, 1981.

CESAR, A. C. "O conto Bliss anotado". In: Crítica e tradução. São Paulo: Ática, 1999.

Ática, 1999.

"O ritmo e a tradução da prosa". In: Crítica e tradução. São Paulo :

CHEVALIER, J. C. et al. Grammaire Larousse du français contemporain. Paris: Larousse, 1964.

CHEVRIER, J. L'arbre à palabres: Essai sur les contes et récits traditionnels de l'Afrique Noire. Paris: Hatier, 1986.

Littérature nègre. Paris: Armand Colin, 1984, cap. 6 e 7.

Littératures d'afrique noire de langue française. Paris: Ed. Nathan, 1999. 
COMBE, D. Les littératures francophones. Questions, débats, polémiques. Paris: PUF, 2010.

CORNEVIN, R. Littératures d'Afrique noire de langue française. Paris: PUF, 1976.

CUNHA, C.; CINTRA, L. Nova gramática do português contemporâneo. 5. ed. Rio de Janeiro: Lexikon, 2008.

DAHLET, V. As (man)obras da pontuação. Usos e significações. São Paulo: Humanitas, 2006.

DAMATO, D. Édouard Glissant: Poética e Política. São Paulo: Annablume, 1995.

DELEUZE, G. "Begaya-t-il”. In: Critique et clinique. Paris: Editions Minuit, 1993, p. 135-143.

DELEUZE, G.; GUATTARI, F. Mil Platôs. Capitalismo e esquizofrenia. v.1. Tradução de Aurelio Guerra Neto e Celia Pinto Costa. São Paulo: Ed. 34, 1995.

DESSONS, G., MESCHONNIC, H. Traité du rythme. Des vers et des proses. Paris: Dunod, 1998.

DUCHATEL, A. Alain Mabanckou: Le rire de l'Afrique. Entre les lignes: le plaisir de lire au Québec, v.04, n.01, p.11, 2007. Disponível em: < https://www.erudit.org/culture/el1057873/el1064191/10736ac.pdf $>$. Acesso em: 12 out. 2016.

FERREIRA, A. B. H. Novo Aurélio século XXI: O dicionário da Língua Portuguesa. 3. ed. Rio de Janeiro: Nova Fronteira, 1999.

GADET, F. Le français populaire. Paris: PUF, 1992.

GLISSANT, E. Introdução a uma poética da diversidade. Tradução de Enilce. Albergaria Rocha. Juiz de Fora: Editora UFJF, 2005.

Le discours antillais. Paris: Seuil, 1981.

L'imaginaire des langues. Entretiens avec Lise Gauvin (1991-2009). Paris: Gallimard, NRF, 2010.

Philosophie de la Relation. Poésie en étendue. Paris : Gallimard, 2009.

Poétique de la Relation. (Poétique III) Paris : Gallimard, 1990.

GREVISSE, M. Le bon usage: Grammaire française. Bruxelas: Éditions J. Duculot, 1959.

HALL, S. A identidade cultural na pós-modernidade. Tradução de Tomaz Tadeu da Silva e Guacira Lopes Louro. Rio de Janeiro: DP\&A, 2006. 
HUSTI-LABOYE, C. La Diaspora postcoloniale en France: différence et diversité. Paris: Pulim, 2010, Capítulo III.

LARANJEIRA, M. Poética da tradução. São Paulo: Edusp, 1993.

LAJRI, N. L'humour dans les romans d'Alain Mabanckou et d'Azouz Begag: de l'autodérision à la singularité. Études Littéraires, v.43, n.01, p.63-72, 2012. Disponível em: < http://www.erudit.org/revue/etudlitt/2012/v43/n1/1014059ar.html?vue=resume $>$. Acesso em: 12 out. 2016.

LE BRIS, M. e ROUAUD, J. (org.). Pour une littérature-monde en français. Paris : Gallimard, 2007.

LEGUY, C. "Formes et masques du dire proverbial". In: BAUMGARDT, U. \& BOUNFOUR, A. Le proverbe en Afrique: forme, fonction et sens. Paris: L'Harmattan, 2004, p.135-157.

LE MONDE. Manifeste pour une littérature-monde en français. 15 mar. 2007. Disponível em: < http://www.lemonde.fr/livres/article/2007/03/15/des-ecrivainsplaident-pour-un-roman-en-francais-ouvert-sur-le-monde_883572_3260.html >. Acesso em: 12 out. 2016.

MABANCKOU, Alain. African Psycho. Paris: Le serpente à plumes, 2003.

Black Bazar. Paris: Seuil, 2009.

Écrivain et oiseau migrateur. Paris: André Versaille, 2011.

. "Le chant de l'oiseau migrateur". In: Le Bris, M. \& Rouaud, J. (orgs.). Pour une littérature monde. Paris: Gallimard, 2007.

. Le sanglot de l'homme noir. Paris: Fayard, 2012.

Les Petits-fils nègres de Vercingétorix. Paris: Le serpente à plumes, 2002.

- "L'obsession des origines : entre diaspora et Congo natal". In : PHILIPPE, N. (org.). Paroles d'auteurs. Ciboure: La Cheminante plein champ, 2013, p. 174-182.

Lumières de Pointe-Noire. Paris: Seuil, 2013.

Mémoires de porc-épic. Paris: Seuil, 2006.

Tais-toi et meurs. Paris: Éditions de la Blanche, 2012 (ed. kindle).

Tant que les arbres s'enracineront dans la terre. Paris: ed. Points, 2007.

Verre Cassé. Paris: Seuil, 2005.

MALONGA, A. N. Roman congolais - tendences thématiques et esthétiques. Paris: L'Harmattan, 2007. 
MANIRAMBONA, F. Esthétique interlinguistique dans l'écriture romanesque d'Alain Mabanckou. Synergies, Afrique des Grands Lacs, n.4, p.77-87, 2015. Disponível em: < http://gerflint.fr/Base/Afrique_GrandsLacs4/manirambona.pdf $>$. Acesso em: 12 out. 2016.

MITTMANN, S. Notas do tradutor e processo tradutório. Análise e reflexão sob uma perspectiva discursiva. Rio Grande do Sul: Editora UFRGS, 2003.

NDOMBI-SOW, Gaël. L'entrance des écrivains africains et caribéens dans le système littéraire francophone. Les oeuvres d'Alain Mabanckou et de Dany Laferrière dans les champs littéraires français et québécois. 2012. Tese (Doutorado em Letras) - Université de Lorraine, Lorraine, 2012. Disponível em: < http://www.theses.fr/2012LORR0365 >. Acesso em: 12 out. 2016.

NGO NLEND, C. E. \& FONKOUA, P. Hétéroglossie et hétérogénéité littéraires dans la prose romanesque d'Alain Mabanckou. ANADISS, n.09, jun-jul., p.125-145, 2010. Disponível em: < http://www.litere.usv.ro/anadiss/arhiva/anadiss.09.pdf >. Acesso em: 12 out. 2016.

NOGUEIRA, P. S. D. A questão da identidade em Alain Mabanckou. Revista Boitatá, Londrina, n.17, p.88-100, jan-jul. 2014. Disponível em: < http://revistaboitata.portaldepoeticasorais.com.br/revista/edicao/numero-17-semestrejan-jul-2014/18 >. Acesso em: 12 out. 2016.

A tradução de provérbios em Alain Mabanckou, Revista Non Plus, n.7, p.5466, 2015. Disponível em: < http://www.revistas.usp.br/nonplus/article/view/98248 >. Acesso em: 12 out. 2016.

NURSE, D. Tense and Aspect in Bantu. Nova York: Oxford University Press, 2008.

PANAÏTÉ, O. Des littératures-mondes en Français. Amsterdam/Nova York: Ed. Rodopi B.V., 2012.

PINHAS, L. Aux origines du discours francophone. Communication et langages, v.140, n.1, p.69-82, 2004. Disponível em: < http://www.persee.fr/doc/colan_03361500_2004_num_140_1_3270 >. Acesso em: 17 out. 2016.

PORRA, V. Malaise dans la littérature-monde (en français): de la reprise des discours aux paradoxes de l'énonciation. Recherches et Travaux, 76, p.108-129, 2010.

PRETI, D. (org.). Análise de textos orais. São Paulo: Humanistas, 2003.

RECLUS, O. France, Algérie et colonies. Paris: BnF, 1886.

REY, A. (Org.). Le Robert Micro. Dictionnaire de la langue française. 3.ed. Paris: Le Robert, 2006.

SARDIN, P. De la note du traducteur comme commentaire: entre texte, paratexte et pretexte. Palimpsestes, 2007. Disponível em: < http://palimpsestes.revues.org/99 >. Acesso em: 29 jul. 2016. 
SCHLEIERMACHER, F. E.D. Sobre os diferentes métodos de traduzir. Trad. Celso Braida. Princípios. Natal, v.14, n.21, p.233-265, jan/jun 2007.

SILVA, M. B. Uma palavra só não basta: um estudo teórico sobre as unidades fraseológicas. Revista de Letras, n.28, v.1/2, jan/dez, 2006. Disponível em: < http://www.periodicos.ufc.br/index.php/revletras/article/view/2308 >. Acesso em: 12 out. 2016.

SINGOU-BASSEHA, A. Confidences et révélations littéraires. Paris : L'Harmattan, 2012.

STEINBERG, M. Provérbios e tradução. TradTerm. São Paulo, v.2, p.59-65, 1995. Disponível em: < http://www.revistas.usp.br/tradterm/article/view/49915 >. Acesso em: 12 out. 2016.

XATARA, C., \& OLIVEIRA, W. L. D. PIP, dicionário de provérbios, idiomatismos e palavrões, francês-português, português-francês. São Paulo: Cultura Editores Associados, 2002.

\section{Sitografia:}

http://www.college-de-

france.fr/media/presse/UPL181793705361781418_DP_A_Mabanckou.pdf

http://dictionnaire.tv5.org/dictionnaire

http://evene.lefigaro.fr/livres/actualite/alain-mabanckou-black-bazar-1807.php

http://evene.lefigaro.fr/livres/actualite/alain-mabanckou-renaudot-memoire-porc-epic734.php

http://www.francophonie.org/

http://www.jeuneafrique.com/Article/ARTJAJA2509p022-027-bis.xml0/

http://www.languefrancaise.net/Bob/Introductionhttp://www.lexpress.fr/culture/livre/ent retien-avec-alain-mabanckou_815535.html

http://www.lemonde.fr/livres/article/2007/03/15/des-ecrivains-plaident-pour-un-romanen-francais-ouvert-sur-le-monde_883572_3260.html

http://mondesfrancophones.com/dossiers/edouard-glissant/traduire-la-relation-deslangues-un-entretien-avec-edouard-glissant/

http://motspluriels.arts.uwa.edu.au/MP1299mabanckou.html 


\section{Anexo}

\section{Anexo - exemplo de página do romance Mémoires de porc-épic}

il y a quelques heures à peine, je veux dire aux premières lueurs de l'aube de ce dimanche où je te parle, j'ai secoué la poussière qui recouvrait mon ventre et mon derrière, je n'avais pas perçu tout de suite pourquoi aucun villageois n'était passé près de ces deux grosses pierres où je m'étais retiré toute la nuit, j'ai compris par la suite que ce jour est un jour de repos, autrement j'aurais vu les chasseurs, les tireurs de vin de palme et autres paysans qui vont aux champs dès l'apparition de l'aurore, et donc, avant de quitter les deux pierres, je me suis étiré, j'ai bâillé, j'ai suivi mon instinct, je progressais de guingois, je ne sais pas comment j'ai débouché devant cette rivière pour une fois désertée par les canards sauvages et les autres animaux, je voulais la franchir à un endroit où l'eau était moins profonde, j'ai préféré l'éviter de peur de me

\section{MÉMOIRES DE PORC-ÉPIC}

noyer, et c'est en cherchant à la contourner que je suis parvenu jusqu'à toi, voilà pourquoi depuis ce matin, mon cher Baobab, je suis assis à ton pied, je te parle, je te parle encore même si je suis certain que tu ne me répondras pas, or la parole, me semble-t-il, délivre de la peur de la mort, et si elle pouvait aussi m'aider à la repousser, à lui échapper, je serais alors le porc-épic le plus heureux du monde

en réalité, et j'ai honte de te l'avouer, je ne veux pas disparaître, je ne suis pas sûr qu'il y a une autre vie après la mort, et s'il en existe une autre je ne veux rien savoir, je ne veux pas rêver d'une vie meilleure, le vieux porc-épic qui nous gouvernait avait raison lorsqu'il nous lâchait une de ses pensées dont il appréciait aussitôt l'effet causé dans le groupe * à force d' espérer une condition meilleure, le crapaud s'est retrouvé sans queue pour l'éternité », disons que le crapaud ne s'est pas seulement retrouvé sans queue, on l'a en outre affecté d'une telle laideur que même le prendre en pitié serait une offense, et donc, mon cher Baobab, quand les hommes parlent de l'autre vie ils se font des illusions, les pauvres, et cette autre vie ils la voient sous un ciel bleu, avec des anges partout, ils n'en 


\section{Apêndices}

\section{Apêndice A — Notas de rodapé}

Reunimos aqui separadamente as 8 notas de rodapé elaboradas, com o objetivo de facilitar sua leitura e análise. Reforçamos que estas são notas pontuais, referentes a fraseologismos ou léxico vindo de línguas autóctones. Não há intenção, com elas, de direcionar a leitura da obra, são apenas complementos culturais que podem acrescentar conhecimentos e curiosidades à leitura particular de cada um:

${ }^{1}$ Batêkê: Nome dado ao povo que habita a África central, principalmente a República do Congo, o Congo e o Gabão. Esse povo cria historicamente cães e gatos para fins domésticos. O chien batéké magro é um pequeno cão de caça com curto ou médio pelo cinza.

2 Nzambí Ya Mpungú: Nome dado a Deus em kikongo, língua bantu falada na República do Congo e outros países africanos.

3 "não tive que usar minhas cartas na manga": Em francês, Mabanckou usa a expressão "le jeu n'en veut pas la chandelle", que data do século XIX, quando se utilizavam castiçais para iluminar os jogos de apostas. Dizia-se que "o jogo não valia o castiçal" quando a soma de dinheiro ganhada era menor do que o preço do castiçal. Corresponde a "não valer a pena" em português, mas optei, na tradução, por uma expressão que remetesse, de alguma forma, ao original, chegando por fim à expressão "usar as cartas na manga", que alude ao jogo de cartas.

4 "sem dúvida com a intenção de me golpear por trás igual a esse animal idiota que os humanos chamam de burro": Aqui Mabanckou refere-se à expressão "le coup de pied de l'âne", que faz alusão a um insulto ou maldade feita por alguém mais fraco a alguém mais forte, mas sem condições de se defender. É também uma alusão à fábula de La Fontaine, Le lion devenu vieux, em que o burro só se atreve a dar um coice no leão quando este já está caído, quase morto, indefeso.

${ }^{5}$ Caxinguelê: No original se lê "rat palmiste", mas optei pelo termo "caxinguelê", oriundo do quimbundo kaxinjiang'elê, "rato de palmeira", por fazer ressoar uma língua africana.

${ }^{6}$ Bubu: Túnica longa e larga, de uso na África negra. Vem do malinquê, pelo francês boubou. 
7 "moças de alegria": Em francês, "filles de joie", um eufemismo para falar das prostitutas.

${ }^{8}$ Bembê: Uma das línguas bantu faladas na República do Congo. 


\title{
Apêndice B - Tradução de Mémoires de porc-épic
}

\author{
Alain Mabanckou \\ Memórias de porco-espinho \\ Tradução \\ Paula Souza Dias Nogueira
}

Dedico estas páginas ao meu amigo e protetor o Escargô cabeçudo, aos clientes do bar $\mathrm{O}$ crédito viajou, e a minha mãe Pauline Kengué de quem peguei esta história (com algumas mentiras)

como cheguei catastroficamente ao seu pé

então eu sou só um animal, um animal de nada, os homens diriam uma besta selvagem como se não existissem outras mais bestas e mais selvagens que nós na espécie deles, para eles eu não passo de um porco-espinho, e como só acreditam naquilo que veem, deduziriam que não tenho nada de particular, que pertenço ao grupo de mamíferos munidos de longos espinhos, acrescentariam que sou incapaz de correr tão rápido quanto um cão de caça, que a preguiça me obriga a não viver longe do lugar em que me alimento

para dizer a verdade, não invejo os homens, tiro sarro da pretendida inteligência deles já que eu mesmo fui durante muito tempo o duplo do homem que chamávamos Kibandí e que morreu anteontem, eu, eu me enterrava a maior parte do tempo não longe do vilarejo, só me juntava a esse homem tarde da noite quando tinha que executar as missões precisas que ele me confiava, tenho consciência das represálias que ele me teria feito se tivesse escutado enquanto vivo eu me confessar como agora, com uma liberdade de tom que ele teria entendido como ingratidão porque, sem aparentar, ele acreditou a vida inteira que eu lhe devia alguma coisa, que eu não passava de um pobre figurante, que ele podia decidir o meu destino como bem entendesse, pois bem, sem querer puxar a sardinha pro meu lado, eu também posso dizer a mesma coisa a respeito dele já que sem mim ele não teria passado de um vegetal miserável, a sua vida humana não teria valido nem mesmo três pinguinhos de xixi do velho porco-espinho que nos governava na época em que eu ainda fazia parte do mundo animal 
tenho quarenta e dois anos hoje, me sinto ainda muito jovem, e se eu fosse um porcoespinho como esses que se arrastam pelas plantações deste vilarejo eu não teria tido uma vida tão longa porque, para nós porcos-espinho desta região, a gestação dura entre noventa e três e noventa e quatro dias, podemos no melhor dos casos viver até os vinte e um anos quando estamos em cativeiro, mas qual o interesse de passar a vida em reclusão como um escravo, qual o interesse de imaginar a liberdade atrás das grades, hein, eu sei que certos animais preguiçosos gostariam disso, esquecendo até mesmo que a doçura do mel não consolará jamais a picada de abelha, eu, eu prefiro os imprevistos da vida na savana às jaulas nas quais vários dos meus compadres que são sequestrados ficam para terminar um dia ou outro como bolinhas de carne nas marmitas dos humanos, é verdade que tive o privilégio de bater o recorde de longevidade da minha espécie, de ter a mesma idade que o meu mestre, não finjo que ter sido seu duplo foi uma sinecura, era um trabalho de verdade, os meus sentidos eram solicitados, eu lhe obedecia sem hesitar ainda que durante as últimas missões eu começasse a recuar, a me dizer que nós cavamos nossa própria cova, eu devia entretanto lhe obedecer, assumia a minha condição de duplo como uma tartaruga que carregava a sua carapaça, era o terceiro olho, a terceira narina, a terceira orelha do meu mestre, o que significa que aquilo que ele não via, aquilo que ele não sentia, aquilo que ele não escutava, eu lhe transmitia em sonhos, e quando ele não respondia às minhas mensagens, eu aparecia diante dele na hora em que os homens e mulheres de Sêkêpembê estavam indo para os campos 
não dei assistência ao nascimento de Kibandí como esses duplos que nascem no mesmo dia que a criança que eles verão crescer, aqueles são duplos pacíficos, eles não se expõem diante do seu mestre, só interveem em casos precisos, por exemplo quando seu iniciado fica doente ou quando ele é vítima do azar, os duplos pacíficos levam uma vida monótona, aliás não sei como suportam tal existência, eles são moles, lentos, a sua preocupação primeira é a fuga assim que há barulho, essa atitude idiota os faz desconfiar até mesmo da própria silhueta, ouvi dizer que a maior parte deles era surda, cega, que não se podia entretanto surpreender a sua vigilância devido a seu faro infalível, digamos que eles protegem o ser humano, o guiam, traçam o caminho da sua existência, morrem como nós no mesmo dia que seu mestre, a transmissão de tal poder é assegurada pelo avô desde o nascimento do ser humano, o velho pega o recémnascido depois de consultar os seus genitores, desaparece com ele atrás da cabana, fala com ele, o agride, afaga, agita, faz cócegas, joga pra cima, pega de volta enquanto o espírito do duplo pacífico sai do corpo do idoso para se infiltrar no do pequeno ser, o iniciado se dedicará a fazer o bem, se distinguirá pela sua generosidade sem limites, dará dinheiro aos paralíticos, aos cegos, aos mendigos, respeitará seus iguais, estudará as plantas com o intuito de curar os doentes e garantirá a transmissão dos seus dons às gerações futuras assim que aparecerem os primeiros cabelos brancos na cabeça, é uma vida mais que tediosa para não dizer monótona, eu não teria tido nada para lhe contar hoje se fosse um desses duplos pacíficos sem história, sem nada de excepcional

pertenço antes ao grupo dos duplos nocivos, nós somos os mais agitados dos duplos, os mais perigosos, os menos comuns também, e como você pode adivinhar a transmissão de tal duplo é mais complicada, mais restrita, ela acontece ao longo do décimo ano de vida da criança, é preciso ainda fazer com que ela engula a bebida iniciática chamada mayamvumbí, o iniciado a beberá regularmente a fim de sentir o estado de embriaguez que o permite se duplicar, liberar seu outro ele mesmo, um clone bulímico que não para de correr, de cavalgar, de saltar rios, de se enterrar na folhagem quando não está roncando na cabana do iniciado, e eu, eu me encontrava no meio desses dois seres, não como espectador já que, sem mim, o outro eu do meu mestre teria sucumbido para satisfazer a sua gula, posso lhe garantir que se os pais das crianças a quem se transmite um duplo pacífico estão sabendo da iniciação e a encorajam, não acontece o mesmo quando se tem a transmissão de um duplo nocivo, aqui ela se opera contra a vontade da criança, se desenrola escondido da mãe, dos irmãos, das irmãs, os seres humanos dos quais nós nos tornamos então a encarnação animal não se deixarão mais dominar por sentimentos como a piedade, a comiseração, o remorso, a misericórdia, enfrentarão a noite e, uma vez a transmissão feita, o duplo nocivo deverá abandonar o mundo animal para viver perto do iniciado, ele executará sem protestar as missões que este lhe confiará, aliás desde quando nós vimos um duplo nocivo desdizer o homem do qual dependa a sua existência, hein, jamais vi com memória de porco-espinho, e não são só os elefantes que possuem uma memória confiável, isso é ainda um dos preconceitos da espécie humana 
bem antes do meu mestre começar a brincar com o fogo, eu saboreava a felicidade de alguns meses de repouso, aproveitava para contemplar a vida que acontecia a minha volta, o ar fresco enchia os meus pulmões, a alegria me deixava agitado e eu corria, corria sempre, parava no topo de uma colina de onde eu podia varrer com o olhar a agitação da fauna, eu adorava observar os outros animais, as suas vidas cotidianas, quer dizer que eu podia me reunir à savana, eu podia desaparecer, não dar mais satisfação ao meu mestre, eu via o sol se pôr, depois fechava os olhos para escutar os grilos antes de ser acordado na manhã do dia seguinte pela cantoria das cigarras, e durante esses períodos de inatividade, de trégua, eu mordiscava muito, quanto mais eu comia, mais eu tinha fome, aliás não me lembro mais quantas plantações de tubérculos eu assombrei para a grande desgraça dos camponeses de Sêkêpembê que acusavam injustamente um monstro meio-homem meio-animal e cujo estômago era tão profundo quanto o buraco da sua ignorância, depois eu ia na primeira hora surpreender os patos selvagens que se agitavam no rio, as suas penas multicoloridas refletiam na água, eu me divertia ao vê-los desfilar sobre as águas sem se afogar, eles voavam para outros espaços assim que um deles soava o fim da recreação ou que um caçador se aventurava na região, a última hora da manhã abria o desfile das zebras, das corças, dos javalis, depois dos leões que circulavam em bando ao longo desse rio, os pequenos na frente, os velhos rugindo por nada, esse mundo animal não se cruzava, existia como uma repartição natural do tempo, era só bem mais tarde, quando o sol já estava a pino, que aparecia o exército dos macacos, eu assistia às disputas entre os machos, sem dúvida por uma questão de autoridade ou de fêmea, eu via isso como uma diversão, os gestos deles me lembravam os dos humanos, sobretudo quando esses antropoides se distraíam com seus excrementos de nariz, se arranhavam as partes genitais, cheiravam em seguida os dedos antes de exprimir imediatamente desgosto, e eu me perguntava se entre eles alguns não eram o duplo nocivo de seres humanos, depois me reformulava, sabendo que um duplo nocivo era obrigado a se afastar da vida em comunidade

sim eu era um porco-espinho feliz nessa época, e eu eriço os meus espinhos enquanto o afirmo, o que é uma maneira para nós de jurar, ou então nós levantamos a pata direita e a agitamos três vezes seguidas, eu sei que os humanos costumam, eles, colocar em jogo a cabeça dos seus defuntos ou convocar seu Deus que eles jamais viram e adoram de olhos fechados, eles consagram assim a sua existência a ler Suas palavras reportadas num livro grosso que os homens de pele branca trouxeram para cá na época longínqua quando os habitantes desse país cobriam seus sexos ridículos com a ajuda de pele de leopardo ou folhas de bananeira e ignoravam que atrás do horizonte viviam outros povos diferentes deles, que o mundo se estendia também depois dos mares e dos oceanos, que quando a noite caía aqui, noutro canto era dia, que quando chovia aqui, noutro canto fazia sol, e parece que o meu mestre Kibandí possuía esse livro de Deus no qual existem várias histórias que os homens são forçados a crer com o risco de não merecerem um lugar no que eles chamam de o Paraíso, você duvida que eu tenha metido o meu nariz lá dentro por curiosidade já que eu podia ler correntemente como o meu mestre, me acontecia aliás de ler em seu lugar quando ele estava esgotado, então percorri esse livro de Deus, páginas inteiras, muito palpitantes e patéticas, lhe digo, sublinhei passagens com a ajuda dos meus espinhos, escutei com as minhas próprias pequenas orelhas muitas dessas histórias da boca de pessoas sérias, de pessoas de barbicha grisalha, de pessoas que iam aos domingos à igreja do vilarejo, elas contavam essas histórias com tal precisão e tal fé que teríamos deduzido que tinham elas mesmas sido testemunhas oculares dos fatos assim relatados, saiba que o episódio mais contado pelos bípedes dotados do verbo é aquele de um tipo misterioso, uma espécie de errante carismático, o filho de Deus, eles admitem, ele veio ao mundo por um meio muito complicado, nem mesmo se detalha nesse livro como o seu pai e a sua mãe se acasalaram, é esse tipo que passeava nas águas, é ele também que transformava água em vinho, e que também multiplicava os pães para alimentar o povo, e que também respeitava as prostituídas sobre quem a população jogava pedras, e que também restituía pernas aos paralíticos mais desesperados, a vista aos cegos, e ele veio à terra para salvar a humanidade inteira, incluindo nós os animais porque, escute bem, já em tempos remotos, para preservar ao menos um espécime de cada espécie viva na terra, não se esqueceram de nós, também nos agruparam nessa 
caixa batizada de Arca de Noé para que sobrevivêssemos a uma chuva torrencial de quarenta dias e quarenta noites, o Dilúvio era o nome disso, mas veja que muito tempo depois o filho único que Deus enviou aqui para baixo foi alvo dos homens incrédulos, sem fé que o flagelaram, crucificaram, largaram em pleno sol ardente, e no dia do seu julgamento por aqueles mesmos que o acusavam de ter perturbado a ordem pública devido a seus milagres espetaculares, quando foi preciso escolher entre ele e um outro acusado, um personagem medíocre sem fé nem lei que denominavam Barrabás, preferiram absolver esse bandido de longa data, e eles o mataram, esse pobre filho de Deus, mas você acha, ele voltou do Reino dos mortos como alguém que acordava de uma pequena siesta de nada, e se lhe falo desse tipo misterioso não é para me afastar das minhas confissões, é que estou persuadido de que ele não era qualquer um, esse filho de Deus, era um iniciado como o meu mestre, devia ser entretanto protegido por um duplo pacífico, ele nunca tinha feito mal a ninguém, eram os outros que procuravam chifre em cabeça de cavalo, digamos que se Kibandí não lia mais essas histórias, se ele preferia antes o universo dos livros esotéricos, é porque estimava que o livro de Deus reprimia as suas próprias crenças, criticava as suas práticas, o afastava dos ensinamentos dos seus ancestrais, então ele não acreditava nem um pouco em Deus na medida em que Este sempre confiava a realização das preces ao amanhã enquanto o meu mestre desejava resultados concretos e imediatos, ele não ligava para promessas de um paraíso, é por isso que lançava às vezes, na tentativa de cortar rapidamente as discussões dos crentes mais determinados do vilarejo, "se você quer que Deus se divirta, conte a ele seus projetos", e depois os homens bem que juraram pela cabeça dos seus defuntos ou pelo nome do seu Todo-Poderoso, e é isso que eles fazem desde que o mundo é mundo, e acabam um dia ou outro traindo a própria palavra porque eles sabem que a palavra não é nada, só engaja aqueles que acreditam nela 
assim que me retirava para a floresta depois de uma missão, eu aproveitava o tempo para meditar numa toca, às vezes no topo de uma árvore ou nas suas cavidades, também nas margens do rio, longe do desfile dos patos e de outros animais, eu fazia uma análise das nossas atividades com o meu mestre, este dormia um sono profundo, repunha as forças depois de uma noite exaustiva, a minha meditação podia se prolongar até a noite do dia seguinte, isso não me esgotava, eu estava antes feliz de manejar coisas abstratas e, já nessa época, eu tinha rapidamente aprendido a discernir as coisas, a procurar a melhor solução para um obstáculo, os homens estão equivocados ao se vangloriar disso, estou convencido de que eles não nascem inteligentes, eles se beneficiam certamente de uma aptidão para isso, a inteligência é uma semente que precisamos regar para ver um dia florescer, se tornar uma árvore frutífera bem enraizada, alguns ainda continuarão tão ignorantes e incultos quanto um rebanho de carneiros que se joga de um barranco porque um deles se jogou primeiro, outros ficarão idiotas assim como esse astrólogo cretino que cai no fundo de um poço ou mesmo esse corvo imitando a águia que sequestra um carneiro, outros ainda persistirão na sua imbecilidade a exemplo do lagarto que se excita, balança a cabeça ao longo do dia, esses humanos viverão na escuridão, a sua única consolação será a de serem homens, o velho porco-espinho que nos governava teria dito a respeito deles "são todos cretinos, serem homens é o último argumento deles, ora não é porque a mosca voa que isso fará dela um pássaro", vou lhe dizer que nas minhas cogitações eu procurava compreender o que tinha por trás de cada ideia, cada conceito, eu sei agora que o pensamento é algo essencial, é ele que inspira nos homens a tristeza, a piedade, o remorso, até a maldade ou a bondade, e se o meu mestre varria esses sentimentos com as mãos, eu os provava depois de cada missão cumprida, senti muitas vezes as lágrimas rolarem dos meus olhos porque, palavra de porco-espinho, quando estamos cheios de tristeza ou de compaixão sentimos um aperto no coração, os pensamentos se tornam sombrios, nos arrependemos dos nossos atos, da nossa má conduta, mas como eu só era um executor, consagrava a minha existência ao meu papel de duplo, chegava a superar as minhas ideias sombrias e depois me consolava murmurando que tinham atos mais desonestos nesta terra, então eu respirava fundo, roía algumas raízes de mandioca ou de noz de palma, tentava fechar os olhos, dizer que amanhã seria um outro dia, rapidamente outra missão me era confiada, eu devia me preparar, sair do meu esconderijo, ir para perto da cabana ou do ateliê do meu mestre, escutar as suas instruções, é claro que eu podia me rebelar, é claro que eu sonhava em escapar do controle do meu mestre, eu pensava nisso de tempos em tempos, a tentação era grande, ao menos poderia eu ter evitado certos atos, estava como que paralisado e não fazia nada, não pude nem mesmo fazer algo antes de ontem quando eu só tinha como solução a covardia, a fuga à maneira de um duplo pacífico enquanto o meu mestre dava o último suspiro que iria conduzi-lo ao outro mundo, e eu assistia, impotente, a sua agonia, a essa cena que ficou gravada na minha memória, desculpe a minha emoção, a minha voz trêmula, preciso de um momento para respirar 
a bem ver eu não deveria mais ser deste mundo, deveria ter morrido anteontem junto com Kibandí, era o pânico, a surpresa, nós tínhamos sido pegos de supetão, nada tinha sido previsto para impedir os acontecimentos em tais circunstâncias, eu tinha me tornado um patético porco-espinho que fugia, na verdade não tinha imediatamente acreditado na minha própria sobrevivência, e já que um duplo morre no mesmo dia que seu mestre, eu me dizia que eu não passava de um fantasma, e quando vi Kibandí soluçar, depois entregar a alma, fiquei na hora enlouquecido porque, como teria dito o nosso velho governante em seu tempo, "quando se cortam as orelhas, o pescoço deveria se preocupar", e eu, eu já não sabia mais o que fazer, aonde ir, andava em círculos, o espaço parecia se reduzir a minha volta, eu temia que o céu caísse sobre mim, tinha a respiração cortada, tudo me amedrontava, pensei que era preciso que eu tivesse agora mesmo a prova da minha existência, ora como ser persuadido que existimos, que não somos apenas uma casca vazia, uma silhueta sem alma, hein, eu tinha para isso alguns truques eficazes que aprendi com os homens da região, bastava me perguntar o que diferenciava um ser vivo de um fantasma, a princípio refleti que se eu pensava, eu existia, ora eu sempre sustentei que os homens não tinham o monopólio do pensamento, por outro lado os habitantes de Sêkêpembê afirmam que os fantasmas também pensam já que eles retornam para assombrar os vivos, encontram sem dificuldade os caminhos que levam ao vilarejo, perambulam pelos mercados, vão dar uma olhadinha nos seus antigos domicílios, vão anunciar a sua morte nos vilarejos ao redor, se sentam num bar, pedem vinho de palma, bebem como esponjas, dizem pagar as dívidas contraídas enquanto vivos, e entretanto eles não existem a olhos nus, veja que eu não estava mais seguro de nada, precisava de uma outra prova, então tentei um truque velho como o mundo, esperei a aparição do sol no sábado, quer dizer ontem, saí do meu esconderijo, olhei para a esquerda, olhei para a direita, sentei-me no meio de um terreno vazio, mexi as minhas patas da frente, as cruzei, descruzei, e então, palavra de porco-espinho, eu nem acreditava, constatei com satisfação que a minha silhueta se mexia, seguia o ritmo dos meus membros, eu estava vivo, não tinha mais dúvidas sobre isso, e eu poderia ter ficado lá, juro, pois bem, não, não estava seguro, não queria fazer besteira, me decidi por procurar uma outra prova de vida, aquela que eu achava a mais eficaz, fui ver meu reflexo no rio, lá também mexi as minhas patas traseiras, as cruzei, descruzei, vi a minha silhueta fazer os mesmos movimentos, eu não era então um fantasma porque conforme aquilo que sei até agora, e sempre por intermédio dos humanos de Sêkêpembê, os fantasmas não têm silhueta, perdem a representação física, se transformam em coisas imateriais, eu não estava entretanto certo da minha existência apesar das provas irrefutáveis que teriam sido suficientes para qualquer aldeão, precisava de uma outra experiência, uma última, dessa vez mais física, e como eu passeava agora ao longo do rio eu primeiramente chafurdei na poeira depois, tomando coragem, me joguei na água, senti o frescor da nascente, disse a mim mesmo, agora muito seguro, que ainda estava vivo, o pior é que eu teria me afogado se não tivesse rapidamente saído do rio, e logo depois fui dar uma volta perto da cabana do meu mestre, para ver um pouco como as coisas estavam por lá, me escondi atrás do ateliê, percebi com estupefação o corpo de Kibandí sob um galpão de folhas de palmeira, ele tinha de fato partido para o outro mundo, mas o que mais me espantava era que, de longe, eu tinha a impressão de que o seu cadáver possuía uma cabeça de animal, digamos uma cabeça que se parecia com a minha, uma cabeça entretanto dez vezes maior, ou talvez fosse a apreensão da minha própria desaparição que me projetava essas ilusões, a morte estava lá, estava diante de mim, batia no ritmo do meu coração, podia dar um jeito em mim nos minutos ou horas seguintes, muitas questões me vieram à mente, por exemplo "e se um caçador me tomasse por sua presa, hein", ou ainda "e se uma inundação me levasse em direção ao turbulento rio Niarí, hein", essas interrogações me impediam de ficar sereno, estava nervoso, angustiado, o mínimo barulho me fazia retroceder, a covardia dos duplos pacíficos me ganhava, foi assim que fui me esconder numa gruta, era a primeira vez que colocava as minhas patas lá dentro, os meus medos não eram infundados já que me inquietei imediatamente pelos assobios de um réptil, não tive tempo de identificar a sua espécie, saí de lá rolando sobre mim mesmo, o medo na palma da mão, eu pensava que um réptil que assobiava como aquele só podia soltar um veneno mortal, não queria morrer daquele jeito, com um veneno mortal, saí rapidinho da gruta, era preciso atravessar a estrada em direção às últimas cabanas do vilarejo, lá ainda um perigo me aguardava, caminhões de transporte pegam essa rota uma vez por semana, eu não me 
lembrava mais em qual dia esses veículos sem freios passavam pela região, escolhi não cruzar a estrada, nunca se sabe, e caminhei pela vizinhança, a imagem do cadáver do meu mestre com a minha cabeça se impunha, eu perdia vários espinhos pelo caminho, e depois tive vergonha de mim, o lado humano tomando conta cada vez mais do meu lado animal, me achei patético, covarde, um pobre egoísta, disse a mim mesmo que não podia me entregar assim, no entanto não via mais o que fazer no estado em que estavam as coisas, eu iria no máximo suscitar a curiosidade dos cães batêkês ${ }^{153}$ e o vilarejo inteiro iria me perseguir a fim de me abater, não resisti à pequena voz que me falava, ela crescia, me ordenava realizar um gesto digno de mim, um gesto que agradaria o defunto Kibandí, então voltei à cabana do meu mestre um pouco mais tarde, com o perigo de ser localizado pelos cães batêkês, felizmente esses vigias com rabos não estavam em seus postos, tive tempo de ver o que se passava no cortejo do meu mestre, estavam na verdade levando-o ao cemitério, Kibandí não teve direito ao funeral que dura pelo menos de cinco a seis dias no vilarejo, iam enterrá-lo menos de 24 horas depois da sua morte, notei um pequeno grupo de homens transportando o corpo ao cemitério, reconheci a família Mundjulá que estava na origem da morte do meu mestre, com seus dois filhos, os gêmeos Koty e Kotê, era mais uma formalidade do que um enterro de verdade, juro, ninguém chorava, palavra de porcoespinho, era por pouco que os aldeões não murmuravam "tudo se paga aqui embaixo, finalmente esse malfeitor do Kibandí está morto, que ele vá pro inferno", e ao ver como arrastavam o caixão aquilo foi pior que um rasgo no coração, estou certo de que se lhe prestaram um simulacro de última homenagem foi porque, queiramos ou não, no mundo dos homens se enterram os mortos independentemente da sua maldade, foi então que o feiticeiro entoou uma oração fúnebre bem contra a sua vontade, dois marmanjos se ocuparam rapidamente de recobrir a fossa, o cortejo partiu em silêncio enquanto eu não tirava os olhos da cruz fabricada com a ajuda de galhos mortos de uma mangueira, essa cruz um pouco tombada para a esquerda, que sobressaia do montinho de terra que servia agora de túmulo ao meu defunto mestre, distingui um velho lampião que os aldeões tinham deixado perto do sepulcro para que o defunto pudesse ver o seu caminho nas trevas da morte, e sobretudo para que ele não voltasse ao vilarejo entre os habitantes ao se infiltrar no ventre de uma mulher grávida, os aldeões estão aliás convictos de que os mortos que não têm um lampião perto do túmulo correm o risco de andar sobre os outros defuntos a quem eles devem respeitar pois eles os precederam, achei esse ato muito gentil da parte das pessoas conscientes de que Kibandí só lhes tinha causado desgraças, vi o grupo voltar para o vilarejo em fila indiana, escutei os seus cochichos, as suas suposições acerca da morte do meu mestre, tapei as orelhas porque eles contavam coisas que mal se podia acreditar, na verdade eu queria mesmo me aproximar da última moradia de Kibandí, aspirar a terra sob a qual ele repousava, não o fiz, me afastei na hora soluçando, me sentia culpado de ter antes escolhido a fuga como um covarde, me virei para observar uma última vez o seu túmulo, enfim fui embora ainda sem saber para onde ir, a noite caia sobre o vilarejo, as sombras se formavam diante de mim, não via mais nada, achei por acaso um lugar para passar a noite, estava confinado entre duas pedras grandes, tive que cavoucar a terra por um bom tempo para conseguir um lugar, eu sabia que esse lugar era um abrigo provisório, que eu não devia me eternizar lá porque alguns aldeões afiam as suas enxadas nesse lugar antes de ir para os campos, e, durante a noite, resisti ao sono porque pensei que a morte e as trevas são amigas de longa data, e assim que consegui descansar um pouco, esquecendo a minha condição de condenado à morte e a imagem desse cadáver com a minha cara implantada em cima, sonhei que estava caindo numa fossa enorme, sonhei também que me encontrava no meio de flamas que devastavam a savana inteira, semeavam o pânico até mesmo entre nossos inimigos eternos que são os leões, os leopardos, as hienas manchadas, os chacais, as onças, os tigres ou as panteras, acordei sobressaltado, estava espantado de sentir zumbirem os meus espinhos, estava surpreso de distinguir as coisas, "eu ainda estou vivo, ainda estou vivo, não estou morto, palavra de porco-espinho", pensei, era preciso a qualquer preço sair desse lugar, e foi isso que fiz naquela hora

${ }^{153}$ Nome dado ao povo que habita a África central, principalmente a República do Congo, o Congo e o Gabão. Esse povo cria historicamente cães e gatos para fins domésticos. O chien batéké magro é um pequeno cão de caça com curto ou médio pelo cinza. 
faz no máximo algumas horas, quero dizer nos primeiros raios do amanhecer deste domingo do qual lhe falo, tirei a poeira que cobria meu ventre e meu traseiro, não percebi imediatamente porque nenhum aldeão tinha passado perto dessas duas pedras grandes onde tinha me retirado a noite toda, entendi em seguida que esse era um dia de repouso, senão eu teria visto os caçadores, os extratores de vinho de palma e outros camponeses que vão aos campos desde a aparição da aurora, e então, antes de sair das duas pedras, me estiquei, bocejei, segui meu instinto, andava em zigue-zague, não sei como cheguei diante desse rio dessa vez abandonado pelos patos selvagens e outros animais, eu queria atravessá-lo para um lugar onde a água fosse mais rasa, preferi evitar isso com medo de me afogar, e foi enquanto procurava contornar o rio que me deparei com você, é por isso que desde hoje cedo, meu querido Baobá, estou ao seu pé, falo com você, falo ainda que esteja certo de que você não me responderá, ora a palavra, me parece, nos salva do medo da morte, e se ela pudesse também me ajudar a afastar a morte, a escapar dela, eu seria então o porco-espinho mais feliz do mundo

na verdade, e tenho vergonha de admitir a você, eu não quero desaparecer, não tenho certeza de que existe uma outra vida após a morte, e se ela existe não quero saber de nada, não quero sonhar com uma vida melhor, o velho porco-espinho que nos governava tinha razão quando nos deixava com um dos seus pensamentos cujo efeito no grupo ele apreciava imediatamente "de tanto esperar uma condição melhor, o sapo ficou sem rabo por toda a eternidade", digamos que o sapo não apenas se encontrou sem rabo, além disso foi afetado por tal feiura que mesmo sentir pena dele seria uma ofensa, e então, meu querido Baobá, quando os homens falam da outra vida eles se iludem, coitados, e essa outra vida eles a veem sob um céu azul, com anjos em todo canto, só dizem coisas boas, eles se veem num jardim, numa savana tranquila onde o leão não terá mais presas, garras e soltará risadas em vez de rugidos, a morte não existirá mais, o ciúme, o ódio, a luxúria desaparecerão, os seres humanos serão iguais, eu, eu quero acreditar nessas coisas, o que é que me certifica entretanto que poderei pelo menos continuar sendo um porco-espinho, hein, talvez me reencarnarei em minhoca, em joaninha, em escorpião, em medusa, em lagarta das palmeiras, em lesma ou não sei que outro bicho execrável e indigno da minha espécie atual que me deixaria invejoso de qualquer outro animal, você vai talvez objetar que eu só falo da boca para fora, que sou um charlatão, um estúpido com espinhos, ora eu não critico as outras espécies animais pelo prazer de exagerar, a modéstia é às vezes um obstáculo que nos impede de existir, é por isso que valorizo as minhas próprias qualidades desde que entendi que para nos aceitarmos como somos é melhor minimizar o repertório dos nossos defeitos, prefiro por exemplo os meus belos espinhos aos tumultos crônicos dos cães do vilarejo, não falo nem mesmo de certos pobres animais neste mundo onde sempre terá alguém mais deserdado que você, a lista é longa, seria mais fácil calcular as minhas dezenas de milhares de espinhos do que fazer um recenseamento dos animais que culpam o criador deste mundo, penso na pobre tartaruga e a sua carapaça rugosa, no elefante e a sua tromba pesada, no infeliz búfalo e os seus chifres ridículos, no imundo porco e o seu focinho que ele enfia na lama, na serpente desprovida de patas e que se move rastejando, no chimpanzé macho e os seus testículos que balançam como cabaças cheias de vinho de palma, não nomeio nem mesmo o pato e as suas patas achatadas que lhe impõem uma moleza de gastrópode, contamos assim uma multidão de pobres criaturas aqui embaixo, nossa espécie não tem nada a invejar das outras, e ainda que os humanos não tenham muita boa fé eles me dariam razão porque, palavra de porco-espinho, aqui eu me desculpo por levantar o tom de voz, ah não, não me contentava em roer as cascas a alguns metros do lugar onde dormia ou ainda em me esconder nas tocas como um inativo, não me satisfazia em comer os ossos dos animais mortos ou das frutas caídas de uma árvore, e, uma vez a minha missão acabada, lhe digo, retornava para a floresta, me encolhia na minha solidão, solidão que nunca me pesou até sexta-feira passada, eu refletia sobre o sentido a dar às minhas relações com o meu mestre, não lhe deixarei imaginar que nesses momentos eu era apenas um ser sobrecarregado, testado, que caiu na armadilha do seu estranho destino, ah não, quero então viver aqui e agora, viver tanto tempo quanto você, e depois, cá entre nós, não vou colocar fim aos meus dias sob o pretexto de que não teria mais direito à vida, você me entende, hein, tento ver as coisas pelo lado positivo, adoraria me divertir 
de tempos em tempos, mostrar que o riso não foi sempre próprio ao homem, palavra de porcoespinho

não sei se você reparou hoje cedo quando comecei a falar com você, não quis chamar a sua atenção para esse fato insólito, percebi um lagarto de certa idade avançar na minha direção, ele parou a alguns metros, olhou para trás, colocou a língua para fora, agitou o rabo, e eu vi seus olhos arregalados pela estupefação, ele parecia congelado numa estátua de sal, estava tão horrorizado pela minha atitude de matraca sem interlocutor que saiu pela tangente, desapareceu num buraco de ratos com seus riscos e perigos, eu ri como um corcunda porque fazia muito tempo que não ria desse jeito, imediatamente contive esse estado porque tem gente que morre de rir neste vilarejo, e quando penso nesse pobre lagarto me digo que talvez fosse a primeira vez que ele surpreendia um animal se comportando como um ser humano, falando numa linguagem coerente, agitando a cabeça em sinal de aprovação, apontando uma das suas patas traseiras para o céu a fim de jurar, tive piedade desse réptil ainda que nosso governante tivesse frequentemente alegado que eu tinha muito medo de lagartos quando era pequeno, o dessa manhã deve ter pensado que estava sonhando, e eu, eu continuei a falar com você como se nada tivesse acontecido

a minha escolha de me esconder ao seu pé não foi por acaso, não hesitei um só instante assim que o vi beirando o rio, me disse que seria ali que me abrigaria, quero na verdade tirar proveito da sua experiência de antepassado, só precisa ver as rugas que se entrelaçam em volta do seu tronco para compreender como você soube se adequar à alternância das estações, até mesmo as suas raízes se prolongam longe, bem longe no ventre da terra, e, de vez em quando, você agita os seus galhos para impor uma direção ao vento, lembrar à natureza que só o silêncio permite viver tanto tempo assim, e eu, palavra de porco-espinho, eu estou aqui tagarelando, me espantando cada vez que uma folha morta escapa do seu topo, é preciso contudo que eu respire um pouco antes de prosseguir, tenho a respiração cortada, as ideias se misturam cada vez mais, acho que estou falando muito rápido desde esta manhã, tenho vontade de beber um pouco de água, me contentaria em lamber o orvalho do mato que me rodeia, não vou correr o risco de me afastar do seu pé, isso não, acredite em mim 
ela está bem longe, essa época na qual eu devia me separar do meu ambiente natural a fim de me aproximar daquele que era apenas uma criança e que eu chamava com afeição de "o pequeno Kibandí", os anos passaram, as lembranças são precisas como se tivesse sido ontem, Kibandí e seus pais viviam então no norte do país, bem longe daqui, em Mossaká, uma região de água, de árvores gigantes, de crocodilos e de tartarugas gordas como montanhas, tinha chegado a hora de abandonar o universo dos animais, de começar a minha existência de duplo, eu devia me revelar a meu jovem mestre, e o pequeno Kibandí sentiu a minha presença desde os primeiros dias em que comecei a me manifestar com mais insistência, a ajudá-lo a ver com mais clareza na vida, não sei o que teria acontecido se nossa fusão não tivesse acontecido o mais rápido possível, cheguei no momento exato, ele tinha dez anos, a idade exigida para receber um duplo nocivo, e assim que eu cheguei às portas desse vilarejo do Norte, vi o menino atrás do seu pai, teríamos acreditado ser uma silhueta, eu tinha pena dessa criança que acabava de ser iniciada, essa criança que não conseguia mais acalmar a embriaguez causada pela absorção do mayamvumbí, o seu pai acabava de lhe fazer ultrapassar um grande obstáculo, um novo mundo se abria para ele, tinha se tornado uma nova criatura, o ser frágil que os aldeões de Mossaká viam atrás de Papa Kibandí era apenas uma marionete, uma espécie de envelope vazio cujo conteúdo tinha evaporado e esperava em algum lugar a hora para encontrar o seu duplo, formar com ele uma única e mesma entidade, o pequeno Kibandí não dormia mais, devia lutar contra os efeitos desse líquido ritual, e, durante esse tempo, da minha parte, eu me agitava cada vez mais na floresta, a savana se tornava invasiva, um lugar que eu não suportava mais, procurava um jeito de me subtrair dela para ir viver perto do vilarejo do meu jovem mestre, ignorava então que eu iria ser submetido à fúria do velho porco-espinho que nos governava, ele que xingava os humanos de todos os nomes ao longo do dia

esse período foi o mais tumultuoso da minha existência já que eu fazia coisas para o menino e para nossa pequena família de porcos-espinho, eu provocava a cólera do nosso patriarca, ele estava cada vez mais intransigente, como se tivesse farejado as mudanças que ocorriam na minha vida, como se tivesse pressentido o que iria me acontecer, ele multiplicava doravante as reuniões, nos olhava de cima, levantava o tom de voz, se exprimia com gestos afetados, acariciava a barbicha com a ajuda das garras para enfim cruzar as patas traseiras, a cara virada em direção ao céu como um ser humano que invocava Nzambí Ya Mpungú, ${ }^{154}$ nós não tínhamos nada a dizer já que a última palavra era dele, ele nos assegurava por exemplo que tal rio passava antigamente do outro lado, e assim que perguntávamos quanto tempo esse curso d'água demorou para fazer essa mudança espetacular o velho agitava os seus espinhos usados, fingia refletir de olhos fechados, nos mostrava o céu, eu, eu ria alto, isso o irritava a ponto de ele nos ameaçar, proferia o seu ultimato que nós conhecíamos de cor, "se é assim, não lhes direi mais nada sobre os homens e seus hábitos, vocês são uns ignorantes", e como nós ainda ríamos ele acrescentava, enigmático, "quando o sábio mostra a lua, o imbecil olha sempre para o dedo", mas como eu não freava mais meu desejo de ir ver o que se passava do lado dos primosirmãos do macaco nosso velho porco-espinho se irritava, pedia aos outros compadres para não largarem da minha pata, será que ele sabia que eu devia entrar em cena assim que o menino Kibandí bebesse o líquido iniciático, hein, ele não sabia, meu querido Baobá, eu saia escondido, às vezes com a cumplicidade de dois ou três compadres a quem eu prometia contar os verdadeiros costumes dos humanos já que nosso velho porco-espinho pregava mais o exagero e apelava praticamente à guerra da espécie animal contra a espécie humana, os meus sumiços da savana duravam dias e noites, eu só me sentia melhor quando estava nas redondezas do vilarejo do meu futuro mestre, o governante ficava fora de si quando eu voltava para nosso território, me xingava de todos os nomes de aves, e, para diminuir ainda mais a minha imagem, repetia aos meus compadres que os humanos tinham feito com que eu perdesse a razão, que eu ia direto

\footnotetext{
${ }^{154}$ Nome dado a Deus em kikongo, língua bantu falada na República do Congo e outros países africanos.
} 
para a boca da raposa, que corria o risco de esquecer os nossos hábitos, que iria me afastar daquilo que fazia com que fôssemos os animais mais nobres da savana, e o nosso velho filósofo jurou que um dia eu cairia nas armadilhas que os homens faziam na savana, pior, eu poderia mesmo sucumbir às armadilhas ridículas das crianças de Mossaká que aprendiam a capturar aves graças à bacia de alumínio das mães, os outros porcos-espinho se dobravam em dois de rir porque, para eles também, era melhor cair numa armadilha feita por um verdadeiro caçador do que numa feita por um ser humano que ainda mamava na mãe, e, essas armadilhas de crianças, nós as víamos por todo lado às portas desse vilarejo do Norte, mas é preciso dizer, meu querido Baobá, que só as aves de Mossaká se deixavam capturar dessa maneira, penso sobretudo nos pardais que são os pássaros mais tolos do país, não quero generalizar a idiotice deles às outras espécies de vertebrados cobertos de plumas, dotados de um bico e cujos membros traseiros servem ao voo, ah não, tenho certeza que existem espécies inteligentes entre as aves, ora os pardais de Mossaká tinham um quociente intelectual tão baixo que me inspirava piedade, todos os pardais do mundo devem ser parecidos, entendo que sejam afastados da realidade do que se passa na terra devido ao fato de voarem aqui ou acolá, as armadilhas das crianças do Norte eram destinadas a eles, esses pequenos humanos dispunham no meio de um vasto terreno bacias suspensas com a ajuda de um pedaço de madeira em volta do qual eles amarravam um longo fio que mal se podia ver, então se escondiam num arbusto, a uma centena de metros, e os infelizes, seduzidos pelas sementes espalhadas em volta das bacias, se agitavam, piavam sobre o topo das árvores antes de decidir unanimemente aterrissar sem tomar o cuidado de designar alguns vigias que os alertariam em caso de pepino, depois os meninos tiravam o fio de armadilha para idiotas enquanto os pardais se encontravam prisioneiros sob o recipiente, mas o que era estranho, meu querido Baobá, era que nenhum deles farejava esse perigo que teria saltado aos olhos de qualquer animal mesmo desprovido de experiência, esses voláteis não eram capazes de dizer que era curioso encontrar um recipiente no meio de um terreno vazio, que era estranho que tivessem sementes na terra e que outras bestas com bicos as ignorassem, eu jamais cai nesses truques, senão não estaria aqui para the contar tudo isso, e então, os meus compadres, doutrinados pelo nosso governante, já imaginavam que eu iria cair nessas armadilhas, "o tambor é feito da pele do veadinho que se afastou da sua mãe", profetizava nosso australopiteco, persuadido de que eu não compreendia o sentido das suas palavras, e as suas afirmações suscitavam uma grande bagunça no grupo, vários compadres as repetiam a todo o tempo, imitavam os gestos do patriarca, aliás tinham começado a me azucrinar me chamado de "veadinho" até o dia em que, irritado pelas piadas que não me faziam mais rir nadinha, eu lhes expliquei que veadinho era o filhote de uma fera, de um veado, de um gamo ou de um cervo, ora eu, eu era um porco-espinho, um porco-espinho orgulhoso de sê-lo

já que o animal que vira o duplo nocivo de um ser humano deve abandonar o seu meio natural, sua família, foi então lá em Mossaká que a minha separação com os membros do nosso grupo foi consumada, nós tínhamos entretanto a sorte de viver em comunidade quando se é sabido que o porco-espinho tem a reputação de ser um animal solitário, e nosso velho governante dava conselhos toda noite, proferia suas generalidades, eu via bem que ele falava de mim disfarçadamente quando afirmava que nada era insubstituível na floresta, que porcosespinho pretenciosos, ele os tinha conhecido, que sabia como colocá-los em seus lugares, e como eu não retrucava ele se tornava mais preciso, resmungava frases do tipo "o peixe que desfila no afluente ignora que acabará cedo ou tarde como um peixe salgado vendido no mercado", ele não hesitava mais em lembrar que eu era órfão, que sem ele eu não teria sobrevivido, contava que os meus progenitores eram tão teimosos quanto eu, que eles tinham abandonado essa terra algum tempo depois da minha vinda ao mundo, eu tinha só três semanas, e nosso governante se vangloriava de ter me acolhido, ele e sua defunta fêmea, detalhava como eu defecava ao longo do dia, como eu não passava de um preguiçoso, como os pequenos lagartos me assustavam, e os outros riam ainda mais, foi também por ele que aprendi sobre os costumes dos meus progenitores, parece que eles amavam frequentar a espécie humana, sumiam de noite, erravam sem rumo ao lado dos humanos de Mossaká, só voltavam na manhã seguinte, morriam de sono, os olhos vermelhos, as garras entrevadas, passavam o dia todo dormindo 
como bichos-preguiça, o governante não tinha nenhuma explicação para isso, comecei a reconstituir aos poucos o que tinha sido a existência deles, não tinha mais dúvidas quanto a isso, eles eram duplos nocivos, cheguei a essa conclusão no dia que senti em mim o chamado do jovem Kibandí, aceitei a ideia de que eu descendia de uma linhagem de porcos-espinho cujo destino era o de servir os humanos, não para o melhor, mas para o pior, e eu me irritava com nosso governante cada vez que ele falava da morte dos meus progenitores, ele fingia que tinha tentado espiá-los uma noite para ver aonde eles iam com tanta pressa, mas eles o despistaram entre dois arbustos pois o velho já tinha problemas de vista na época, uma semana se passou sem que dessem notícias, depois teve esse dia sombrio, o oitavo dia do sumiço deles, esse dia de tristeza no qual uma coruja com a pata esmagada pelas armadilhas dos homens sobrevoou nosso território, veio, parecia, anunciar ao governante a má notícia que estava na goela da maior parte dos animais da nossa área, ela lhe contou que um caçador tinha abatidos os meus progenitores não longe de Mossaká, todo o grupo teve que se mudar apressadamente e achar um território há muitos quilômetros de lá

nunca soube do destino dos meus progenitores já que não os tinha conhecido, deixava o velho porco-espinho contar suas mentiras aos outros, eu confiava no meu instinto, desaparecia cada vez mais da savana, aliás não espaçava mais as minhas escapadas, e pela primeira vez desapareci por quatro dias e quatro noites seguidas, só seguia reto diante de mim, mais nada me fazia parar, era mais forte que eu, e os compadres, perturbados, me procuraram por todo canto, vasculhavam os bosques onde costumávamos beber enquanto um de nós observava se não tinham caçadores emboscados nas proximidades, eu não estava lá, e, em desespero de causa, eles se informavam com outros animais da nossa espécie, estes não sabiam de qual porcoespinho lhes falavam quando me descreviam, alguns diziam que eu avançava vasculhando cada centímetro quadrado, outros acrescentavam que eu costumava me esconder atrás das árvores como se temesse sempre um perigo, e naquele dia o governante especificou que eu tinha um passo de porco-espinho cuja pata tinha sido machucada por uma armadilha de criança que ainda mamava na mãe, ele fingia que eu claudicava, que eu capengava, vários dos meus compadres denunciaram essa mentira cabeluda, continuaram suas buscas porque me apreciavam, e como eu adorava me enterrar nas cavidades dos troncos das árvores, em particular de árvores como você, eles examinavam primeiro as cavidades dos Baobás, depois das palmeiras ao redor, atrapalhavam na passagem a intimidade dos esquilos que não deixavam de lhes bater com nozes de palma antes de os xingar na língua deles, e eu, durante esse tempo, estava perto de Mossaká com o intuito de me impregnar da criança da qual seria o duplo, tinha uma vaga ideia sobre ela pois a via em sonho quando, no coração da noite, sentia em mim uma vibração vinda de não sei onde e que só percebiam os animais predispostos a fundir com um ser humano, ora eu queria ter certeza de que não me confundira de criança, estava longe de pensar que iria me eternizar em Mossaká, que iria abandonar os meus compadres para sempre 
na verdade, meu querido Baobá, naquela época eu não tinha partido do nosso território com a ideia de não mais voltar, juro que queria a vida em comunidade, estava convencido de que podia levar uma vida dupla, viver uma de noite, outra de dia, que podia ao mesmo tempo estar perto do meu mestre e continuar ao lado dos meus compadres, o que era infelizmente incompatível com a natureza de duplo, e foi então, durante meu périplo em direção a Mossaká, que senti em mim o líquido que acabavam de fazer o jovem Kibandí beber, comecei a vomitar, as vertigens me atrapalhavam a vista, os meus espinhos se tornavam cargas difíceis de carregar, só olhava para o que estava a minha frente, um pouco como se o menino me chamasse em socorro, ele precisava de mim, eu devia estar lá, senão o pior iria lhe acontecer, eu tinha a sua vida entre as minhas patas, respirava o sopro que vinha dele, eu era ele, ele era eu, e para reestabelecer as coisas eu devia me manifestar urgentemente, o meu coração ia explodir, não sabia mais quem eu era, onde estava e o que ia fazer em Mossaká, eu devia avançar, andar, seguir o primeiro caminho que encontrasse diante de mim, tinha quilômetros e quilômetros a percorrer, claro que eu não podia chegar no mesmo dia, mas devia partir, e como chovia naquele dia, chegando na metade do percurso fui obrigado a me retirar à noite numa gruta até o dia seguinte, é preciso dizer que não gosto muito da chuva porque vários dos nossos compadres morreram levados pelas águas até o coração das cascadas do rio Niarí, só encontrei no interior da gruta alguns sapos e pequenos ratos a quem eu podia intimidar, alcancei as paragens de Mossaká no dia seguinte ao pôr do sol, e então, chegando enfim à porta do vilarejo, acabado, com baba na cara, pálpebras pesadas, dormi atrás de uma cabana perto de um rio que descobria pela primeira vez, era um braço do Niarí que corta o país em dois, repousei ali, decidi que tomaria um tempo para procurar a cabana da família Kibandí na manhã seguinte porque, me arriscando em plena noite, seria apanhado por caçadores ou cães batêkês, e foi no meio da noite que senti uma corrente de ar, folhas mortas voando, depois um barulho estranho como se alguma coisa viesse na minha direção, "palavra de porco-espinho, é um homem, é um homem que me viu e quer me abater, preciso fugir", eu disse a mim mesmo num momento de pânico, quis imediatamente sair do meu esconderijo, salvar a minha pele, infelizmente estava paralisado, impossível de mexer uma pata sequer, como se me tivessem feito dormir, mas estava enganado, era antes o barulho de um animal que se movia, ericei os meus espinhos sem nem ter identificado antes o animal que se aproximava cada vez mais, esperava que fosse menor que eu, que temesse os meus espinhos, estava pronto para projetá-los se fosse necessário pois eu conseguia fazer isso diferentemente da maioria dos meus iguais, não precisei chegar a esse ponto, não tive que usar as minhas cartas na manga, ${ }^{155}$ respirei fundo, me acalmei quando descobri enfim o animal diante de mim, quase morri de rir, dei razão ao nosso governante que sustentava que durante os meus primeiros meses na terra eu me assustava até com a visão de um pequeno lagarto, nesse dia eu não precisava me assustar, era só um pobre rato que parecia ter errado o caminho e se encontrava diante de mim, tive dó dele, talvez quisesse informações, eu não podia fazer nada por ele, não conhecia as redondezas, e depois, mudando de ideia, disse a mim mesmo que esse rato parecia ainda assim bizarro, sua aparência de lesma revelava o peso da idade que acabou por imobilizar suas patas traseiras, esse rato não era como os outros, estava lá por uma razão específica, talvez para me eliminar, me impedir de chegar até o pequeno Kibandí, me desafiava agora com os olhos exorbitados, mexeu o beiço, eu continuei parado, o deixei crer que não seria um rato de Mossaká que me faria estremecer, que na minha existência já tinha visto outros mais impressionantes, e ele rodou em torno de mim, cheirou meu sexo, o lambeu antes de desaparecer num buraco de uma casa a uma centena de metros de lá, entendi enfim que essa casa era aquela que eu procurava, o velho rato era o duplo nocivo de papai Kibandí, ele vinha confirmar meu status de duplo do seu filho, era o fim da transmissão que tinha começado com a absorção do líquido iniciático, e a transmissão acontece desta maneira, primeiro entre os seres humanos, o iniciador e o iniciado por meio da absorção do mayamvumbí,

\footnotetext{
${ }^{155}$ Em francês, Mabanckou usa a expressão "le jeu n'en veut pas la chandelle”, que data do século XIX, quando se utilizavam castiçais para iluminar os jogos de apostas. Dizia-se que "o jogo não valia o castiçal" quando a soma de dinheiro ganhada era menor do que o preço do castiçal. Corresponde a "não valer a pena" em português, mas optei, na tradução, por uma expressão que remetesse, de alguma forma, ao original, chegando por fim à expressão "usar as cartas na manga", que alude ao jogo de cartas.
} 
depois entre os animais, o duplo animal do iniciador tendo que lamber o sexo do duplo animal do seu jovem iniciado, na verdade o duplo de papai Kibandí queria se assegurar de que o animal que iria viver com o seu filho era corajoso, um animal que podia guardar o seu sangue-frio diante do perigo, se eu tivesse mostrado sinais de pânico, se tivesse procurado fugir, ele teria me eliminado sem sombra de dúvidas, e ele tinha sido bem atendido, meu querido Baobá

como fazia já quatro dias e quatro noites que eu tinha desaparecido da savana para Mossaká, o acontecimento chegou aos ouvidos dos animais do nosso entroncamento, um rumor se espalhou a respeito de um porco-espinho morto ao pé de uma palmeira, os meus compadres foram para lá correndo, revolveram várias vezes o cadáver do pobre animal carcomido pelas formigas vermelhas, concluíram entretanto que esse porco-espinho não se parecia comigo em nada porque ele tinha uma má formação no nível do focinho, eles não se iludiram, não iriam passar o resto da vida me procurando, deviam se curvar à realidade, tomar as medidas que se impunham, voltaram para a savana em fila indiana, já imaginava nosso governante confirmando com satisfação a minha morte aos outros compadres, lhes explicando que eu tinha sido pego pelas armadilhas dos meninos de Mossaká, eu suspeitava que ele tinha acrescentado que eu era teimoso por natureza, que eu era altivo como os homens, que eu falava muito, que a minha pretensão me levou à ruína, que eu preferia a vida doméstica à liberdade da savana, eu imaginava também que, como de costume, sem dúvida com a intenção de me golpear por trás igual a esse animal idiota que os humanos chamam de burro, ${ }^{156}$ ele tinha se lançado num longo discurso moralista e que, para ilustrar suas afirmações, tinha evocado uma fábula que nos contava com deleção, uma fábula que nos empurrava à reflexão, $O$ rato da cidade $e$ o rato do campo, eu penso que ele tinha contado aos outros que um dia o rato da cidade tinha convidado o rato do campo, e os dois animais estavam comendo com os homens quando escutaram o chefe chegar, saíram de fininho, e quando o barulho enfim parou e o perigo parecia ter dissipado, o rato da cidade propôs de novo ao seu compadre do campo de voltarem para terminar a refeição, o rato do campo declinou essa proposta, lembrou o seu compadre da cidade que na savana ninguém o interrompia quando ele fazia uma boquinha, e então, meu querido Baobá, nosso velho governante talvez tenha ridicularizado numa fórmula violenta a moral dessa fábula que muitos dos meus congêneres não tinham compreendido uma vez mais apesar das explicações que eu lhes murmurava enquanto o velho concluía com um ar desprendido "despreze o prazer que o medo pode corromper", e ele deve ter murmurado, "para que serve a fartura quando não se tem a liberdade, hein", então, acredite, ele tinha de todas as formas possíveis demonstrado que o que tinha acontecido comigo poderia acontecer com aqueles que tentassem se aventurar nas terras dos homens, "é assim que se acaba o destino de um inconsciente, de um pequeno tagarela que eu vi nascer, que eu acolhi, um pequeno que morria de medo de lagartos, que defecava por todo lado, um pequeno que num tem o menor reconhecimento porque a natureza quis que tivéssemos todos espinhos, a pele do veadinho serviu de tambor aos homens, que isso lhes sirva de exemplo", ele talvez tenha concluído, e era, imagino ainda, um dia triste para os meus semelhantes, o velho porco-espinho não devia ter interrompido no entanto o seu sermão porque, volúvel como ele o era, adorava ilustrar suas afirmações ao menos com duas ou três fábulas que ele sabia devido a seus avós, tenho certeza que ele tinha evocado a fábula preferida dos meus compadres, A andorinha e os passarinhos, parece que existia antigamente uma andorinha que tinha viajado muito, visto muito, aprendido muito, incorporado muito das suas viagens a ponto de agourar o mínimo sinal de tempestade aos marinheiros, e a andorinha em questão, segura do seu saber e da sua experiência de migrante, se dirigiu um dia aos passarinhos despreocupados a fim de lhes prevenir contra o perigo que eles correriam com o começo da semeadura dos homens, a andorinha os advertiu que as semeaduras trariam logo sua ruína, que era preciso custe o que custar sabotar os grãos, comê-los uns atrás dos outros, senão

\footnotetext{
156 Aqui Mabanckou refere-se à expressão "le coup de pied de l'âne", que faz alusão a um insulto ou maldade feita por alguém mais fraco a alguém mais forte, mas sem condições de se defender. É também uma alusão à fábula de La Fontaine, Le lion devenu vieux, em que o burro só se atreve a dar um coice no leão quando este já está caído, quase morto, indefeso.
} 
eles só teriam como destino a gaiola ou a marmita, nenhum desses passarinhos escutou a sábia andorinha, cobriram as orelhas com suas asas para não escutar esses raciocínios de uma criatura com penas que, segundo eles, tinha perdido o discernimento com o intuito de percorrer o mundo sem objetivo preciso, e quando a premonição se realizou com grande surpresa da assembleia de passarinhos, vários entre eles foram capturados, feitos de escravos, é talvez nesse estágio da sua história que nosso governante deve ter concluído a fábula dizendo "e nós só acreditamos no mal quando ele chega", não duvido também que ele tenha arriscado na passagem algumas outras alegorias que ninguém conseguiu decifrar na minha ausência já que, como lhe disse, era eu quem tentava explicar aos outros o sentido oculto das parábolas e dos símbolos do velho porcoespinho, e quando ele acabava de contar $A$ andorinha e os passarinhos, seguro da sua sabedoria, soltava com um ar grave que somente ele sabia fazer "eu, eu sou a andorinha em questão, $e$ vocês, vocês são esses pequenos passarinhos inconscientes, não podem compreender, são palavras sábias que ultrapassam vocês", e se os meus compadres ficaram perplexos o velho deve ter lhes disparado uma fórmula ainda mais violenta, do tipo "vocês não entendem nada de nada, somente o velho sábio pode escutar o grilo ejacular", mas dessa vez ele deve ter dito, com mais gravidade na voz "vamos, passemos a outra coisa, nada é insubstituível nessa savana, azar desse veadinho que se comportava como os humanos"

vou dizer que com meu desaparecimento muitos devem ter ficado aflitos, sobretudo aqueles que eram fãs das histórias de homens que eu lhes contava quando o velho nos dava as costas, fingia se entregar a uma meditação profunda, nos dizia para o deixarmos tranquilo em seu recolhimento de patriarca, ia para o topo de uma árvore, fechava os olhos, balbuciava rezas, eu acreditava ter escutado palavras proferidas por um verdadeiro primo-irmão do macaco já que os grunhidos e os murmúrios de um porco-espinho têm uma surpreendente consonância humana, o que garante entretanto meu orgulho até o momento presente é que estou seguro de que vários dos meus compadres não perderam a esperança de me rever um dia, eu era muito prudente para me deixar capturar como um besta pelos meninos de Mossaká, eles deviam se lembrar que eu já lhes tinha mil vezes falado dessas armadilhas das quais tirávamos sarro, eles reconheciam a minha lucidez, o meu faro, a minha inteligência, a minha rapidez, a minha astúcia, eles sabiam que eu podia lhes despistar com uma virada de pata, então talvez os meus companheiros tivessem começado a imaginar o dia do meu retorno entre eles, um grande dia, eles ririam na cara do governante, lhe diriam que esses momentos de sabedoria não passavam de pura fachada, me fariam mil perguntas sobre meu desaparecimento, a minha intromissão no mundo dos primos-irmãos do macaco, por que lhe esconder que as primeiras questões que me teriam feito seriam sobre a condição humana, a relação dos homens com os animais, os meus compadres sempre quiseram saber se os primos-irmãos do macaco estavam convencidos de que nós éramos capazes de refletir, de conceber uma ideia, de formulá-la até o final, eles também sempre quiseram saber se os homens tinham consciência do mal que infringiam aos animais, se se davam conta da sua arrogância, da sua superioridade autoproclamada, vários entre eles só conheciam na verdade os homens pelos preconceitos que nos dizia o governante porque eles nunca tinham colocado as patas no coração de um vilarejo, então eles só viam os homens de longe, acontecia de se torcerem de rir, de reclamarem dos humanos porque eles não utilizam os membros superiores para se movimentar de um ponto a outro, preferindo se impor um deslocamento com a ajuda dos pés, só para mostrar às outras espécies que eles são superiores a elas, os meus compadres escutavam com interesse as caricaturas que nosso governante fazia da espécie humana, este proclamava que o Homem era indefensável, que não merecia nenhuma absolvição, que era a pior das criaturas que podiam existir sobre a terra, que não tinha circunstâncias atenuantes, e já que os humanos nos fazem levar a vida dura, já que eles são hostis e surdos ao nosso chamado à coexistência pacífica, já que são eles que vêm nos caçar na savana, já que não compreendem a necessidade de um acordo depois de uma longa batalha que os dizima, que deixa traços indeléveis nas suas memórias, pois bem, é preciso lhes dar o troco, é preciso levar em conta até mesmo os seus filhos que acabaram de ver o dia porque "os filhotes do tigre não nascem sem as suas garras", assim falava nosso governante, e veja você, meu querido Baobá, que ele não levava de maneira alguma o gênero humano no seu coração 
a minha morte se tornou logo uma certeza em nossa comunidade, eu presumo que foi o governante que decidiu que o grupo devia mudar de lugar o mais cedo possível porque, meu querido Baobá, assim que um de nós morria, emigrávamos durante dois ou três dias à procura de um novo território, duas razões nos impeliam a essa dolorosa migração, pensávamos primeiramente que a mudança de lugar era a única saída contra nossas angústias e pavores na medida em que nutríamos um medo cego do além-vida, acreditávamos na verdade que o outro mundo não passava de um universo de criaturas aterrorizantes, aliás o governante tirava proveito disso para nos explicar que assim que um porco-espinho morria ele voltava alguns dias depois sob os traços de um espírito nocivo entre os seus compadres vivos, se tornava gigante, com espinhos rígidos, mais longos e mais pontudos que as zagaias dos caçadores, e sempre segundo ele os espinhos de um tal porco-espinho tocavam as nuvens, cobriam o horizonte, impediam o dia de nascer, nós vivíamos então com medo desse fantasma que retornaria do reino dos mortos com o intuito de nos aterrorizar, de nos impedir de dormir, de nos arrancar nossos lindos espinhos, de nos ameaçar com os seus longos espinhos envenenados, mas a segunda razão que nos fazia migrar em seguida da morte de um dos nossos relevava antes um instinto de sobrevivência, estávamos convencidos que um homem que tinha abatido um animal num certo lugar estaria tentado a voltar a esse lugar, "um animal prevenido vale por dois", dizia o governante quando o medo do fantasma de um porco-espinho mal-intencionado não era mais suficiente para nos convencer da necessidade de uma migração, e se acontecia de nós contrariarmos sua decisão apesar das suas intimidações, ele lançava, misterioso, "confiem em mim, eu sou como um surdo que corre até perder o fôlego", e acrescentava em seguida, "e se virem um surdo correr, meus pequenos, não façam perguntas, o sigam pois ele não escutou o perigo, ele o viu", é portanto por essas razões que os meus tinham talvez abandonado esse território onde tínhamos nos fixados desde um certo tempo, não tinham deixado nenhum indício que poderia ter me conduzido até o novo território deles, e ainda que alguns tivessem pensado em me orientar em direção ao novo lugar de maneiras dissuadidas, por exemplo abandonando nozes de palma ao longo de uma trilha, espinhos pelo chão, derrubando excrementos ou urina por aqui e por ali, marcando o tronco de cada árvore com as garras, esmagando as flores dos juncos, isso não teria servido a nada, o governante teria apagado suas tentativas, é provável que ele tenha ficado atrás do grupo a fim de melhor observar o périplo, de culpar os espertinhos, e sobretudo de fazer desaparecer os indícios

foi assim que no quinto dia, quando voltei ao nosso território com o objetivo de descansar um pouco após o contato com o jovem Kibandí, não tinha encontrado nenhum dos membros do grupo, tudo estava calmo, as tocas estavam vazias, entendi enfim que o governante tinha dado ordem de evacuar, eu tinha sido declarado morto para os meus, comecei a soluçar diante desse vazio, cada barulho nos bosques me dava a esperança de rever um dos meus compadres que viria me enlaçar, esfregar os seus espinhos contra os meus em sinal de reconhecimento, me azucrinar me chamado de "veadinho", e assim que escutei enfim um barulho os meus espinhos começaram a se agitar de alegria, infelizmente meu entusiasmo durou pouco, percebi em seguida que era apenas um caxinguelê $\hat{e}^{157}$ que se aventurava por ali, o barulho do seu riso irônico já dizia muito, até agora eu não entendo por que esse amadores de noz de palma nos devotam tal ódio a ponto de acharem que nossa infelicidade é a felicidade deles, evidentemente eu não respondi às suas provocações, às suas risadinhas bobas, continuei sozinho durante seis dias, foi apenas no sétimo dia que notei um esquilo de certa idade nas redondezas, e como os esquilos pelo menos nos são mais simpáticos porque nunca brigamos com eles, perguntei a ele se tinha visto um grupo de porcos-espinho sair da região alguns dias antes, ele morreu de rir também, multiplicou os tiques que nós reprovamos aos seres da sua espécie, os esquilos têm de fato tendência a se agitar por nada, revirar os olhos, mexer o nariz, balançar a cabeça de maneira epilética, o que lhes dá uma aparência mais do que ridícula, mas preste

157 No original se lê "rat palmiste", mas optei pelo termo "caxinguelê", oriundo do quimbundo kaxinjiang'ele , "rato de palmeira”, por fazer ressoar uma língua africana. 
atenção, esses tiques os salvam às vezes do fuzil apontado para eles pelos homens, e eu constatava que ele arrastava um rabo cortado, sem dúvida tinha escapado por um triz de uma armadilha dos humanos, a ferida ainda estava aberta, eu não quis me demorar sobre as razões do seu infortúnio, e então, depois do seu riso louco seguido de uma série desses tiques burlescos, ele coçou o traseiro antes de resmungar "estou espiando-o faz um tempo, me perguntava mesmo por que você chorava assim, é então porque está procurando os seus, num é, hein, para dizer a verdade num vi não nenhum porco-espinho andando por essas bandas faz alguns dias, pelo contrário está bem calmo por aqui nos últimos tempos, parece que num tem mais nada não para rangar e que todo o mundo dá no pé, mas bom, se você num tem onde viver a gente pode acolhê-lo em nossa comunidade, será um prazer apresentá-lo aos meus compadres, sobretudo porque a estação das chuvas que está chegando corre o risco de ser rigorosa e sem piedade de acordo com essas nuvens baixas e pesadas como a pança de um asno, venha comigo, nós devemos nos ajudar, nos dar a pata, você entende o que quero dizer, hein", eu não me via vivendo com os esquilos, suportando os seus tiques, compartilhando as suas nozes, arbitrando as suas brigas por uma amêndoa podre, subindo nas árvores ao longo do dia, fiz que não com a cabeça, ele tentou me persuadir, continuei inflexível, antes morrer que me rebaixar a esse ponto, eu disse a mim mesmo, e ele fez "você acha que é quem, hein, o orgulho não dará jamais casa a um vagabundo", e eu respondi, "a casa do vagabundo é sua dignidade", ele se calou, me olhou com desprezo antes de lançar no fim "escute, amigo espinhoso, eu lhe propus nossa hospitalidade, você a recusa, eu queria mesmo lhe ajudar a reencontrar os seus, mas estou com pressa agora como você pode ver aqui, os meus compadres me esperam faz tempo, eles me enviaram para procurar algumas nozes, posso no máximo lhe dizer que sua família partiu pro outro lado, atrás de você", e com a cabeça ele me indicou o horizonte, lá onde o céu e a terra se encontram, lá onde as montanhas se tocam, parecendo apenas um pequeno monte de pedras, eu sabia que ele estava fingindo, que se exultava de me ver nesse estado de tristeza, "sinto muito, preciso ir, lhe desejo sorte daqui para frente, e que sua dignidade lhe conceda uma casa", disse ele, eu o vi partir sem se virar, olhei o horizonte, depois o céu, enxuguei as minhas lágrimas, fiquei andando em círculos por alguns minutos, sempre esse vazio, essa impressão que o silêncio tinha os olhos sobre mim, olhos cúmplices da mudança dos meus compadres, a imagem da nossa comunidade estava diante de mim, eu revia o governante falar, rezar, resmungar ordens, derrubei mais lágrimas nesse instante, e, inspirando longamente, os espinhos a meia haste, disse a mim mesmo "não importa, vou viver sozinho agora", e, dois dias mais tarde, assombrado pela solidão e pela tristeza, retomei o caminho do vilarejo do meu jovem mestre

foi assim, meu querido Baobá, que eu saí do mundo animal a fim de me colocar a serviço do pequeno Kibandí que acabava de ser iniciado em Mossaká, esse pequeno que eu iria seguir bem mais tarde em Sêkêpembê, esse pequeno que eu não iria mais largar durante décadas até a sexta-feira passada quando não pude fazer nada para evitar a sua morte, ainda estou afetado, não queria que me visse aos prantos, vou então virar de costas para você por decência e respirar um pouco antes de prosseguir 
o meu mestre não tinha passado um só dia da sua vida sem rever essa noite quando o seu pai nos tinha vendido o seu destino, e as imagens da iniciação se impunham sobre ele, ele se revia em Mossaká, com 10 anos, em plena noite, uma noite cheia de corujas, de morcegos, essa noite em que Papai Kibandí o tinha acordado à revelia da sua mãe para o arrastar à força pela floresta, e bem antes de sair da cabana o pequeno Kibandí assistiu a uma cena tão pouco provável que ele esfregou os olhos várias vezes, constatou de fato que o seu pai estava ao mesmo tempo deitado ao lado da sua mãe e em pé ao seu lado, tinha portanto dois Papais Kibandí na casa, os dois se pareciam como duas gotas d'água, um estava imóvel, deitado na cama, o outro estava em pé, em movimento, e o menino, repleto de pânico, gritou, mas o pai em pé colocou uma mão na sua boca e lhe disse "você não viu nada, eu sou eu, e aquele que está deitado ao lado da sua mãe, pois bem, também sou eu, eu posso ser ao mesmo tempo eu mesmo e o outro eu mesmo que dorme, você entenderá logo", o pequeno Kibandí quis escapar, o pai em pé o segurou de um só tranco "você não pode correr mais rápido que eu, e se escapar, será o outro eu mesmo que mandarei ao seu encalço", o pequeno Kibandí olhou novamente um de cada vez o seu pai em pé e o outro ele mesmo do seu pai, tinha a impressão que o raptavam, que era preciso talvez acordar esse outro ele mesmo do seu pai que viria então salvá-lo, se perguntou entretanto se era mesmo aquele o seu verdadeiro genitor, e então, o pai em pé o deixou matar a curiosidade antes de sinalizar com a cabeça, isso queria dizer que era a ele que o menino deveria se dirigir, era ele o pai, o verdadeiro, o pequeno Kibandí não tinha mais voz, o pai em pé balançou novamente a cabeça, principiou um sorriso enigmático, meu jovem mestre lançou com desespero um último olhar para a cama dos seus pais, sua mãe tinha agora uma das mãos sobre o peito de Papai Kibandí dormindo, "o outro eu mesmo não acordará se as coisas não forem feitas conforme querem nossos ancestrais, e se ele acordar agora, você não terá mais pai, venha, o caminho é longo", pegou o menino pela mão direita, praticamente o pressionou, a porta continuou meio fechada, eles desapareceram na noite, o pai não soltou um só instante a mão do filho como se temesse que ele saísse de fininho, a caminhada foi interminável, pontuada pelo pio dos pássaros da noite, e quando chegaram enfim ao coração da savana a lua os espiava discretamente, o pai liberou a mão do meu jovem mestre, ele sabia que este não podia mais sonhar com a fuga devido ao seu medo das trevas, Papai Kibandí afastou então um emaranhado de trepadeiras, se orientou em direção a uma plantação de bambus, achou uma velha pá dissimulada sob um monte de folhas mortas, a criança não tirou os olhos dele, eles retornaram, se encontraram numa clareira, se escutava um rio correr um pouco mais abaixo, e Papai Kibandí, com sua voz rouca, entoou uma canção, começou a cavar com a virtuosidade dos desenterradores, esses ladrões de mortalhas que, uma vez tendo cometido o roubo e profanado a sepultura do cadáver, lavavam em seguida os seus panos no rio, os dobravam num saquinho, iam revendê-los a bom preço nos vilarejos vizinhos onde se desenrolavam os funerais, Papai Kibandí ainda cavava, os golpes da pá acabavam com o silêncio da savana, e após vinte minutos, quase uma eternidade para meu jovem mestre, o pai jogou o seu instrumento sobre o monte de terra, soltou um suspiro de alívio, "aqui está, perfeito, estamos aqui, você logo vai ser libertado", deitou de bruços, mergulhou sua mão no buraco para fazer sair um objeto enrolado num pedaço de pano sujo, o menino descobriu um cantil e um copo de alumínio, Papai Kibandí primeiro agitou o cantil várias vezes antes de despejar o mayamvumbí no copo, deu ele mesmo um gole, fez estalar a língua, estendeu em seguida o copo ao filho que recuou dois passos, "mas o que é que você está fazendo, hein, é pro seu bem, beba, beba logo", o pegou pela mão direita, "você tem que beber essa poção, é para sua proteção, não se faça de idiota", e como o pequeno Kibandí, desesperado, se debatia, ele o imobilizou no chão, prendeu suas narinas, o fez beber o mayamvumbí, alguns goles foram suficientes, a reação foi imediata, o pequeno Kibandí começou logo a ter vertigens, caiu no chão, se levantou, cambaleou, mal ficava em pé, os olhos fechados, o líquido tinha ao mesmo tempo gosto de vinho de palma estragado e de água do pântano, a poção queimava a garganta, e assim que abriu os olhos, o meu jovem mestre viu um garoto que se parecia com ele, teve apenas tempo para discernir os traços desse menino que desapareceu entre dois arbustos, "você o viu, o seu outro você mesmo, hein, será que você o viu, 
hein", perguntou Papai Kibandí, "ele estava diante de você, não foi uma ilusão, meu pequeno, agora você é um homem, estou contente, você vai dar continuidade àquilo que eu mesmo recebi do meu pai e que meu pai recebeu do seu pai”, o pequeno Kibandí deu mais importância ao lugar para onde tinha fugido a criança, o seu outro ele mesmo, ainda o ouvia amassar folhas mortas na sua fuga, uma fuga quase demente, a crer que alguém estava ao seu encalço, depois se fez o silêncio, o seu pai podia enfim respirar, tinha esperado por muito tempo esse instante de alforria, esse instante no qual ele seria enfim absolvido da sua dívida de transmissão 
o pequeno Kibandí não teve contato frequente com o seu outro ele mesmo que preferia antes me seguir, me impedir de dormir, eu o escutava andar sobre as folhas mortas, correr até perder o fôlego, respirar num arbusto, beber água num rio, acontecia às vezes de eu achar alimentos amassados perto do meu esconderijo, eu sabia que era o outro ele mesmo do pequeno Kibandí que os tinha colocado lá, estava certo disso, alguém se ocupava então de mim, e era talvez nesses instantes que eu me sentia reconfortado, estava feliz de ser um privilegiado, eu engordava, os meus espinhos se tornavam mais resistentes, podia vê-los luzir quando o sol estava a pino, me acostumava a esse jogo de esconde-esconde com o outro ele mesmo do meu jovem mestre, ele era nosso intermediário, e quando não o via nem escutava durante duas ou três semanas eu ficava inquieto, me orientava com urgência em direção ao vilarejo, só ficava calmo quando via enfim o pequeno Kibandí brincar no pátio da sua concessão, voltava para o meu esconderijo, tranquilizado, e passei anos assim, o outro ele mesmo do meu jovem mestre me alimentava, não me faltava nada, não temia o amanhã, os alimentos me esperavam na entrada do meu refúgio assim que eu colocava o nariz para fora, e se outro animal ousava vir furtá-los, o outro ele mesmo do meu mestre o afastava jogando pedras, pela primeira vez eu podia concordar com os homens que eu levava uma vida de preguiçoso

nada foi concretamente feito durante esse período da adolescência do meu mestre, nós aprendíamos a viver juntos, a coordenar nossos pensamentos, a melhor nos conhecer, era por meio do outro ele mesmo que eu enviava mensagens ao pequeno Kibandí, e depois um dia, eu me arrastava perto de uma nascente, o surpreendi sentado sobre uma pedra, de costas para mim, não quis mais me mexer nem fazer barulho, senão ele iria se salvar uma vez mais, ele observava as garças e os patos selvagens, fui tomado por uma grande emoção a ponto de pensar que era o verdadeiro pequeno Kibandí que me dava as costas assim, avancei alguns metros, ele me ouviu, se virou imediatamente, e era tarde demais, eu tinha distinguido os traços do seu rosto, se tudo nele vinha do meu mestre, o que me pareceu mais estranho foi constatar que esse outro eu de Kibandí não tinha boca, também não tinha nariz, só olhos, orelhas e um longo queixo, mal tive tempo de exprimir a minha estupefação que ele já tinha sumido se jogando na nascente, o voo das garças e dos patos selvagens serviu de cobertura para sua debandada, não tinha mais nada diante de mim, apenas a nascente agitada, foi uma das raras imagens que eu tive desse outro ele mesmo do meu jovem mestre, a última sendo aquela em que essa criatura sem boca veio me anunciar a partida iminente do meu mestre e sua mãe em direção a Sêkêpembê, alguns dias antes da morte de Papai Kibandí 
tudo se passava como se, ao envelhecer, Papai Kibandí estivesse voltando ao estado animal, não cortava mais as unhas, tinha manias de um verdadeiro rato quando precisava comer, coçava o corpo com a ajuda dos dedos dos pés, e as pessoas de Mossaká que entendiam isso como uma brincadeira de mau gosto, como um jogo de velho débil, começaram a se inquietar, o velho tinha agora longos dentes afiados, em particular os da frente, pelos grisalhos e duros se enraizavam nas suas orelhas, chegando até o começo do maxilar, e assim que Papai Kibandí desaparecia perto da meia-noite, Mamãe Kibandí nem percebia, via o outro ele mesmo do seu esposo dormindo na cama, ao seu lado, meu jovem mestre surpreendia então fileiras de ratos que iam e vinham da sala principal ao quarto dos seus pais, ele sabia que o mais gordo desses roedores, $\mathrm{o}$ rato privilegiado de calda longa, orelhas dobradas e patas arqueadas, aquele lá era $\mathrm{o}$ duplo do seu pai, era preciso principalmente não o matar com golpes de bastão, ainda assim um dia ele tinha se divertido fazendo esse velho animal levar uma vida dura, tinha polvilhado raticida sobre um pedaço de tubérculo e deixado na entrada do orifício de onde surgiam os roedores, após algumas horas tinha uma dezena de ratos mortos, meu jovem mestre se apressou em juntar todos os roedores mortos em folhas de bananeira enquanto os seus pais dormiam, foi jogá-los longe atrás da cabana, mas nas primeiras horas do alvorecer, para sua grande surpresa, Papai Kibandí lhe puxou as orelhas "se quer a minha morte, pegue uma faca e me mate de dia, você é hoje aquele que eu quis que você fosse, a ingratidão é uma falha imperdoável, eu espero não precisar discutir mais sobre isso com você”, Mamãe Kibandí não soube nada sobre esse caso, o pai e o filho sabiam do que falavam

e tinham essas mortes que se multiplicavam em Mossaká, mortes que não tinham mais intervalo entre si, os enterros se seguiam, mal se tinha parado de chorar sobre um morto que um outro esperava sua vez, Papai Kibandí não ia a esses funerais, isso suscitava interrogações num vilarejo onde todo o mundo se conhecia, ele viu os olhos da população pousarem sobre ele, as pessoas mudarem de caminho ao cruzarem com ele e sua aparência de rato, e depois tinham também as mulheres que tagarelavam sobre isso às margens do rio, os homens que pronunciavam o seu nome a cada reunião na cabana de discussões, as crianças que choravam, que se agarravam à saia das suas mães assim que o velho aparecia nas redondezas, sem contar os cães batêkês que tinham a precaução de latir à distância ou diante da porta dos seus mestres, Mossaká inteira dizia agora em uníssono que Papai Kibandí tinha alguma coisa, cada detalhe da sua vida foi então dissecado com lupa, com pente fino, o reprovavam agora por não ter tido vários filhos, de ter tido apenas um no momento em que as cinzas recobriam o seu rosto, ele estava na linha de tiro por qualquer uma dessas mortes, o que dizer por exemplo do seu próprio irmão Mataparí morto enquanto serrava uma árvore na savana sendo ele o maior serralheiro de Mossaká, hein, é verdade que esse irmão tinha mudado os seus métodos de trabalho, comprou uma serra elétrica a qual era preciso saber manejar nesse meio onde se usava ainda o machado, Papai Kibandí tinha ciúmes desse instrumento de trabalho, hein, invejava as economias do seu irmão que tirava proveito dessa ferramenta, a emprestava à população, hein, e então o que dizer da morte da sua irmã caçula Manionguí encontrada inerte, sem vida, os olhos virados, na véspera do seu casamento, hein, todo o mundo sabia que Papai Kibandí se opunha a essa união devido a uma história de região, "uma pessoa do Norte não pode se casar com uma do Sul, ponto final", dizia ele, o que dizer também de Matumoná, essa mulher que Papai Kibandí desejava ter como segunda esposa, essa mulher que tinha a metade da idade dele, hein, não tinha ela morrido ao engolir atravessado o seu mingau de milho, hein, e o que dizer de Mabialá o carteiro que ele suspeitava estar dando voltas ao redor de Mamãe Kibandí, hein, e de Lubandá o fabricante de tam-tam de quem ele reprovava o sucesso com as mulheres, hein, e de Senga o pedreiro que tinha recusado trabalhar para ele, hein, e de Dikamoná a corista das cerimônias fúnebres que não lhe dizia bom dia, ela que o tinha tratado de velho bruxo em público, hein, e de Lupialá a primeira enfermeira diplomada vinda de Mossaká, essa jovem mulher que, segundo Papai Kibandí, falava sem dizer nada, essa jovem mulher que se vangloriava do seu diploma, hein, e de Nkêlê o maior agricultor da região, esse homem egoísta que recusava lhe ceder um pedaço de terra perto do rio, hein, que dizer de todas essas pessoas que não eram da sua família, essas pessoas que morriam umas atrás das outras, hein, e então, meu querido Baobá, atribuíam 
esses desaparecimentos ao Papai Kibandí enquanto ele observava o horizonte serenamente, como se ele não pudesse mais mudar o rumo das coisas, como se estivesse acima daquilo que ele mesmo qualificava de "pequenas brigas de lagartos", e já que as pessoas não falavam mais com ele, ele se fechava em seu orgulho, disse ao seu filho e à sua esposa para não discutirem mais com os aldeões, para não dizerem bom dia a ninguém, ele mesmo cuspia no chão quando cruzava com um habitante, chamava o chefe do vilarejo de todos os nomes, de pobre corrompido que só vendia terras à sua própria família, e depois teve esse evento fatídico, um conflito familiar que iria marcar a memória do povo do Norte, essa confusão com sua irmã caçula, a última, ora era falta de conhecimento sobre Papai Kibandí pois ele iria uma vez mais embaralhar as cartas, semear a dúvida no espírito dos aldeões, iria procrastinar o que aparecia entretanto como o termo da sua existência sobre a terra, apenas Papai Kibandí era capaz de tal façanha, acredite em mim, meu querido Baobá, e até agora eu me surpreendo quando rememoro como ele deitou e rolou nesse mundinho

foi ao longo do período de seca que essa desgraça chegou a Mossaká, as águas do Niarí mal chegavam ao tornozelo dos banhistas, encontramos ao cair do sol o corpo sem vida de Nianguí-Bussiná sobre a margem direita, do outro lado da aldeia, ela tinha a barriga inchada, o pescoço torcido como se tivesse sido morta após uma estrangulação por um criminoso de mãos gigantescas, essa moça era a sobrinha de Papai Kibandí, a filha da irmã caçula Etalelí que eu nomearei aqui de Tia Etalelí como a chamava o meu mestre mesmo, a adolescente NianguíBussiná tinha vindo passar as férias em Mossaká com sua mãe, a aldeia delas ficava a alguns quilômetros de lá, Tia Etalelí afirmava que sua filha não podia morrer afogada, não, jamais, ela tinha nascido às margens do rio mais perigoso do país, o Lukulá, tinha passado sua infância na água, era então uma história duvidosa, o nome de Papai Kibandí foi logo evocado, Tia Etalelí ameaçou não sair de Mossaká até que o afogamento da sua filha fosse vingado, e, a tensão aumentando, ela saiu da casa do seu irmão, foi morar na casa de uma das suas amigas, não saiu de lá até o dia em que devíamos levar o corpo da adolescente a Siakí, a aldeia onde Tia Etalelí vivia com o seu esposo, e Papai Kibandí escutou dessa vez a palavra "bruxo" assim que colocou os pés para fora de casa, o tratavam de "rato pestífero", não lhe davam tempo de se explicar, ele teria querido discutir isso com a sua irmã, lhe demonstrar que podia acusá-lo de tudo menos de ter comido a sua sobrinha, e quando eu digo comido, é preciso compreender, meu querido Baobá, que se trata de pôr fim aos dias de um indivíduo por meios imperceptíveis para aqueles que negam a existência de um mundo paralelo, em particular esses incrédulos humanos, e então, palavra de porco-espinho, no dia do enterro de Nianguí-Bussiná em Siakí, esperavam Papai Kibandí com zagaias envenenadas, pretendiam apunhalá-lo em público nessa aldeia onde ele se preparava para ir saudar a memória da sua sobrinha, ele mudou de ideia no último segundo, o seu velho rato que ele tinha mandado inspecionar o terreno se informou sobre aquilo que tramavam contra ele, uma grande armadilha planejada por Tia Etalelí com a cumplicidade de alguns habitantes de Siakí e de Mossaká, tanto que uma semana após o funeral Tia Etalelí reapareceu em Mossaká bem cedo com uma delegação de quatro homens, cruzou com Papai Kibandí, lhe disse abertamente "foi você que comeu Nianguí-Bussiná, foi você que a comeu, todo o mundo o sabe, todo o mundo o diz, você tem que confessar olhos nos olhos", Papai Kibandí recusou a acusação, "eu não a comi, como poderia eu comer a minha própria sobrinha, hein, eu não sei nem como é que se come alguém, a pequena morreu afogada, ponto final", e a irmã aumentou o tom, "se você tem culhões, venha então conosco para Lekaná, o feiticeiro Tembê-Essuká o confrontará diante dessas quatro testemunhas que estão comigo, eu as escolhi em quatro aldeias diferentes, uma delas é aliás de Mossaká", e, para surpresa geral, talvez também devido à multidão que se formava em volta deles, Papai Kibandí não opôs nenhuma resistência, colocou os seus sapatos de borracha, vestiu um longo bubu ${ }^{158}$ de pano, disse de maneira desafiadora "estou à sua disposição, vamos, você perde o seu tempo, minha irmã", Tia Etalelí retrucou "não me chame mais de irmã, não sou irmã de um comedor"

\footnotetext{
${ }^{158}$ Túnica longa e larga, de uso na África negra. Vem do malinquê, pelo francês boubou.
} 
se as quatro testemunhas vindas junto com Tia Etalelí tinham sido escolhidas em quatro aldeias diferentes, era a tradição que o exigia com o intuito de manter a neutralidade e a autenticidade das palavras que essas pessoas transmitiriam nas suas respectivas localidades, $o$ pequeno grupo andou durante meio dia até Lekaná, é lá que vive o famoso feiticeiro TembêEssuká, um velho cego de nascença, com as pernas magras e cuja barbicha varre o chão a cada movimento da cabeça, parece que os responsáveis por este país o consultam, veneram sua ciência das sombras, ele não se lava jamais, senão perderia seus poderes, arrasta velhos trapos vermelhos, faz suas necessidades na cabeceira da sua cama de bambu, é capaz de domesticar a chuva, o vento e o sol, só exige pagamento após o resultado, e ainda, é preciso pagá-lo em cauris, moeda que era usada na época em que este país era ainda um reino, ele não confia na moeda nacional, pensa que os tempos não mudaram, que a moeda oficial é uma ilusão, que o mundo é constituído por reinos, que cada reino tem o seu feiticeiro, que entre todos esses feiticeiros ele é o maior, e assim que você chega diante da sua casa construída em cima de uma colina ele solta uma risada que paralisa os visitantes, começa a lhe explicar o seu passado em detalhes, lhe diz com exatidão a data e lugar do seu nascimento, os sobrenomes do seu pai e da sua mãe, revela em seguida o motivo da sua visita, sacode as máscaras aterrorizantes suspensas em cima da cabeça dele e com as quais faz a comunhão, esse homem iria apaziguar o pai e a tia de Kibandí, as quatro testemunhas tinham tentado de todas as maneiras reconciliar a irmã e o irmão que não tinham trocado uma só palavra durante a travessia da savana, o grupo chegou às portas de Lekaná por volta do meio-dia

meu querido Baobá, os habitantes de Lekaná estavam acostumados aos vai-e-véns das pessoas que se orientavam em direção à colina a fim de consultar Tembê-Essuká, e este, tendo escutado os passos dos visitantes, berrava desda sua cabana à beira de um colapso, "vocês, aí, o que é que vêm fazer na minha casa assim, hein, Tembê-Essuká não está aqui para pequenos assuntos que vocês podem resolver entre vocês, não me incomodem por nada, não preciso dos seus cauris, o culpado não fez a viagem não, eu vejo água, sim, eu vejo água, vejo uma jovem que está se afogando, essa jovem é a sobrinha de um velho senhor que uma dama acusa, se vocês insistem, se não acreditam em mim, entrem então por seus riscos e perigos”, já que Tia Etalelí estava mais que nunca determinada o grupo penetrou na cabana, não foram os odores pútridos que afastaram os seis recém-chegados mas antes as máscaras que pareciam vexadas pela obstinação e pela temeridade desses estrangeiros, Tembê-Essuká tinha o olhar úmido e apagado, estava sentado sobre uma pele de leopardo, agitava um terço fabricado com a ajuda dos ossinhos de uma cobra cuja cabeça se exibia na entrada da cabana, os visitantes se sentaram no chão mesmo, e o feiticeiro, pensativo, murmurou "bando de incrédulos, eu bem os adverti que o culpado não estava com vocês, por que vocês entraram na minha cabana, hein, duvidam então da palavra de Tembê-Essuká ou o quê, hein", Tia Etalelí se pôs de joelhos, começou a soluçar aos pés do feiticeiro, enxugava as lágrimas com a ajuda de um pedaço de pano amarrado em volta da lombar, o feiticeiro a repeliu "sejamos claros, este lar não é um lugar para as lágrimas, tem um pequeno cemitério mais para baixo, a senhora terá apenas o constrangimento da escolha para achar uma carcaça à qual as suas lágrimas darão prazer", Tia Etalelí balbuciou ainda assim "Tembê-Essuká, a morte da minha filha num é uma morte normal não, num é assim que uma pessoa deve morrer, eu lhe suplico, olhe bem, estou certa de que o senhor me ajudará, sua ciência é a mais temida deste país", ela afundou novamente em lágrimas apesar da irritação do feiticeiro, "merda então, silêncio, eu disse, vocês querem que eu os expulse daqui, hein, querem que eu lhes lance um exército de abelhas no pescoço, hein, o que é esta história, vocês acham que eu sou quem, hein, ainda não compreenderam que este velho que está aqui e que vocês acusam dessa desgraça não é aquele que comeu a sua filha, hein, vou ter que dizer quantas vezes, caramba, e agora se vocês insistem em conhecer a verdade, eu vou lhes revelar porque eu, eu vejo tudo, eu, eu sei tudo, e para lhes convencer da inocência do homem que está aqui, vocês irão todos se submeter à prova do bracelete de prata, paciência, eu os preveni, lhes dou trinta segundos de reflexão antes de decidir se devo ou não prosseguir com a prova" 
você não vai acreditar, meu querido Baobá, Papai Kibandí aceitou se curvar a essa prova do bracelete de prata quando mesmo aqueles que estimavam não ter nada a se repreender refletiam duas vezes antes de se submeter a isso, primeiro porque Tembê-Essuká era mais cego que uma toupeira, em seguida o pânico podia distorcer o desenlace da prova, Papai Kibandí não ia recuar, Tia Etalelí tinha secado as lágrimas de repente, ela parecia exultar de antemão a ideia de ver o seu irmão desmascarado aos olhos de quatro testemunhas, o fogo iluminava a cabana, crepitava como esses incêndios que devastam a savana na estação seca, as máscaras pareciam mexer os seus lábios carnudos, sussurrar ao feiticeiro fórmulas cabalísticas às quais ele respondia com acenos de cabeça impetuosos, a fumaça embaçava agora o rosto dos visitantes, eles tossiam uns aos outros, um odor rançoso, depois borrachas calcinadas asfixiavam a assistência, e quando a fumaça enfim cessou Tembê-Essuká colocou no fogo uma vasilha repleta de óleo de palma, jogou um bracelete de prata no seu interior, deixou esse óleo ferver por muito tempo antes de afundar a mão no recipiente sem um momento de hesitação, o óleo quente chegou até o seu cotovelo, ele recuperou o bracelete sem se queimar, o exibiu ao grupo ainda em choque, o recolocou na vasilha, "agora é a vez de vocês, senhora, faça a mesma coisa, encontre para mim o bracelete neste óleo quente", após um instante de tergiversação, Tia Etalelí afundou a mão na vasilha, segurou o bracelete, gritou quase vitória, e as testemunhas, asseguradas, fizeram o mesmo com sucesso, o feiticeiro se voltou então para Papai Kibandí, "é a sua vez, o fiz ir por último porque é você o pretendido comedor", Papai Kibandí foi logo, triunfou sobre a prova sob o olhar surpreso de Tia Etalelí enquanto as quatro testemunhas, estupefatas, pousavam os olhares sobre a acusadora, o feiticeiro diz "as quatro testemunhas e o homem injustamente acusado vão sair desta cabana e esperar lá fora, eu vou lhe revelar, a você senhora, quem comeu sua filha", Tia Etalelí ficou sozinha diante das máscaras com uma cara dessa vez de desgosto e do feiticeiro imerso numa meditação interminável, os olhos fechados, e quando ele os reabriu Tia Etalelí acreditou que o feiticeiro não era cego, ele a fixou direto nos olhos, soltou um latido parecido ao de um cão batêkê, o fogo se apagou de repente, ele se colocou em seguida a contar os ossinhos do seu terço, a murmurar um canto que Tia Etalelí não compreendia, os seus olhos reviravam, dessa vez sem vida, o seu polegar e o seu dedo indicador agarraram um dos ossinhos mais grossos, ele o acariciou com agitação, interrompeu o canto, pegou a mão direita da tia, lhe perguntou "quem é então esse tipo que chamamos de Nkuyú Matêtê e que não paro de ver na minha meditação, hein", Tia Etalelí fez um movimento de sobressalto, se recompôs a tempo para sussurrar "Nkuyú Matêtê, o senhor disse Nkuyú Matêtê, hein", perguntou ela, "você escutou bem, quem é esse tipo aí, hein, ele é muito forte, ele me esconde o seu rosto, só consigo decifrar seu nome, esse tipo está rodeado por vários homens, eles parecem brigar entre si, lançar ameaças de morte", e Tia Etalelí, cética, balbuciou "num é possível não que seja ele, é apesar de tudo meu marido, é o pai da minha defunta filha, o senhor quer dizer que é ele que, hum, enfim, num é possível não, lhe digo que ele não pode comer a própria filha, vejamos", "é ele quem comeu a menina, ele é membro de uma associação noturna em seu vilarejo Siakí, e todo ano um dos membros dá em sacrifício à comunidade dos iniciados um ser que lhe é caro, nesta estação era a vez do seu marido, e como ele tem como duplo nocivo o crocodilo, é pela água que sua filha pereceu, puxada pela correnteza pelo animal do seu pai, agora você tem a última palavra, ou eu chamo as quatro testemunhas e o seu irmão que você acusa, ou você opta pelo silêncio e guarda a minha revelação com você", sem tomar o tempo da reflexão Tia Etalelí propôs "eu quero que o senhor faça alguma coisa contra meu marido, quero que o senhor lhe lance um feitiço, quero que ele morra antes da minha chegada a Siakí, é um vagabundo, um crápula, um feiticeiro", Tembê-Essuká quase reencontrou a vista sob o efeito da raiva, "você acha que sou quem, hein, nunca lancei má sorte às pessoas, me contento em ver, em ajudar aqueles que estão em dificuldade, pro resto vá consultar os canalhas e outros charlatões do seu próprio vilarejo, eu não sou dessa espécie, você acha que sou quem, hein", "eu lhe suplico, Tembê-Essuká, ao menos não diga nada aos que esperam lá fora, não quero sobretudo que meu irmão saiba disso, eu o acusei erroneamente por causa sobretudo das pessoas de Mossaká, elas dizem que ele tem um rato como duplo nocivo, então o senhor me compreende, hein, se coloque em meu lugar", o feiticeiro se levantou, para ele a sessão estava terminada, e, antes de designar a porta à Tia Etalelí, concluiu "é sua história, não direi nada a ninguém, 
Tembê-Essuká fez o seu trabalho, não se esqueça de fechar a porta atrás de você e de deixar alguns cauris para os ancestrais no cesto que está na entrada"

o grupo deixou Lekaná, as quatro testemunhas metralhavam Tia Etalelí de questões, ela continuou muda como uma carpa, e como ela parecia ainda com raiva de Papai Kibandí que exibia um largo sorriso de satisfação, este partiu na direção oposta, andou durante duas horas, não se virou um só instante, foi só bem mais tarde que exteriorizou sua alegria, começou a cantar, teríamos acreditado ser um louco, ele voltava de longe, de muito longe, e, como não podia se impedir de reviver nos seus pensamentos essa cena da prova do bracelete de prata que acabava de inocentá-lo, morreu de rir, murmurou alguma coisa, um pouco como se agradecesse alguém, penetrou na floresta, olhou a seu redor, não tinha ninguém, nem mesmo um pássaro, foi então que subiu o seu bubu até a altura da lombar, agachou como se fosse fazer suas necessidades, deu uma grande inspirada, reteve a respiração, fez força, mais força, se ouviu um barulho de peido, uma noz de palma escapou do seu ânus, ela a pegou, inspecionou, aproximou do seu nariz, sorriu dizendo "meu querido Tembê-Essuká, você é mesmo um cego", Papai Kibandí tinha boas razões para zombar assim desse feiticeiro renomado, tinha então se tornado o primeiro homem a ter ludibriado a vigilância de um feiticeiro tão temido quanto TembêEssuká, ele se enganava de cantar vitória tão rápido 
dizer que o feiticeiro Tembê-Essuká tinha se enganado, meu querido Baobá, é conhecêlo mal já que ele desembarcou dois meses mais tarde em Mossaká à grande estupefação da população, o medo invadiu as cabanas, os animais domésticos se escondiam à vista dessa personagem, o feiticeiro tinha uma novidade para anunciar, as especulações se multiplicaram, perguntava-se sobretudo como esse cego tinha podido se orientar sozinho na savana, e depois dizia-se que na realidade a sua cegueira era uma ostentação já que ele podia tudo ver, foi acolhido pelo chefe do vilarejo como um verdadeiro notável, admitiu que pela primeira vez sua ciência das trevas o tinha deixado na mão, demonstrou que Papai Kibandí era uma ameaça para o vilarejo inteiro, foi então que revelou as práticas do velho, lhe atribuiu a maior parte das mortes de Mossaká, confirmou que Papai Kibandí tinha comido até aquele dia mais de 99 pessoas, "eu vim por vocês, estou aqui para livrá-los dessa desgraça pois este homem é o homem mais perigoso da região, ele não comerá a centésima pessoa", disse ele, e para reforçar suas palavras citou de memória, por ordem alfabética, os nomes das 99 vítimas, apenas uma entre elas habitava fora de Mossaká, a jovem Nianguí-Bussiná, Tembê-Essuká explicou sua morte, era uma troca entre Papai Kibandí e um iniciado do vilarejo Siakí que não era outro que o esposo de Tia Etalelí, na realidade era mesmo Papai Kibandí que tinha organizado tudo, era ele que tinha comido a própria sobrinha, "eu vim livrá-los deste diabo de Papai Kibandí, é a primeira vez que saio da minha cabana e deixo as minhas máscaras sozinhas, é claro que não cabe a mim pôr fim aos dias deste homem aí, Tembê-Essuká não mata jamais, ele livra, vocês é que sabem, basta agarrar o seu duplo nocivo que está agora escondido na floresta porque ele sente que sua hora se aproxima, eu o imobilizei graças aos meus poderes, se vocês puserem a mão sobre este animal vocês farão então o que quiserem do seu mestre, não terão nas suas consciências a morte deste indivíduo já que terão atacado um animal”, ele indicou com precisão onde se escondia o velho rato, lhe agradeceram, lhe ofereceram um jumento branco, um galo vermelho e um saco de cauris, o feiticeiro se recusou a passar a noite no vilarejo, ia voltar a Lekaná em plena noite, o chefe do vilarejo tentou retê-lo "fique e durma aqui, Venerável Tembê-Essuká, já é noite, nos preocupamos com o senhor e com sua sabedoria", o feiticeiro respondeu "Honorável Chefe, estas palavras me vão direto ao coração, mas saiba que para nós cegos a clareza do dia não quer dizer nada, devo voltar para a minha cabana agora, as minhas máscaras me esperam, não se preocupe comigo, obrigado por estes presentes", segurou o galo vermelho pelas patas, prendeu o saco de cauris nas costas do seu jumento, e retomou o caminho da sua terra

no dia seguinte, o primeiro cidadão de Mossaká convocou uma assembleia extraordinária dos anciãos, uma decisão de urgência foi tomada, era preciso capturar Papai Kibandí sem o seu conhecimento, confiaram então a doze valentões a missão de ir caçar o velho rato na floresta, os valentões se armaram de revólveres calibres $12 \mathrm{~mm}$, de zagaias envenenadas, cercaram a zona da savana indicada por Tembê-Essuká, neutralizaram os ratos ao redor, descobriram ao pé de um flamboaiã um buraco de ratos dissimulado com a ajuda de folhas mortas, cavaram, cavaram durante uma meia hora antes de encurralar um animal senil que tinha dificuldades em se mexer, talvez soubesse ele que sua hora tinha chegado, que ele não podia mais se safar desta vez, ergueu o beiço, mostrou os incisivos em sinal de ameaça, isso não assustou mais ninguém, ele inspirava antes a piedade, um líquido âmbar pingava da sua cara, foi então que um dos homens armou sua zagaia, a projetou em direção à besta que guinchava enquanto jorrava um fluído tão esbranquiçado quanto o vinho de palma, uma segunda zagaia fez voar em estardalhaço os seus miolos, e como se isso não bastasse os dozes valentões esvaziaram as balas dos seus calibres sobre o animal que estava no entanto morto desde muito

assim que os valentões voltaram ao vilarejo, foram surpreendidos ao escutar o anúncio da morte de Papai Kibandí, ninguém foi até a cabana do defunto, o cadáver do velho estava estendido na sala, os olhos exorbitados, revirados, e a língua, de uma cor azul índigo, se arrastava até sua orelha direita, o corpo já putrefato, um odor pestilento exalava ao redor, e por volta do fim do dia, quando começava a cair a noite, Mamãe Kibandí e o meu jovem mestre 
enrolaram o cadáver em folhas de palmeira, o levaram longe na floresta, o enterraram num bananal, voltaram com toda discrição para o vilarejo, arrumaram algumas coisas, descamparam assim que amanheceu sem deixar traços, seguiram o horizonte, caíram aqui em Sêkêpembê onde eu já estava, eu os tinha precedido assim que vi errando o outro ele mesmo do meu jovem mestre vindo me anunciar a saída iminente desse vilarejo do Norte, soube então que era preciso ir em direção ao Sul, em direção a um vilarejo chamado Sêkêpembê, foi assim que nos tornamos a contragosto habitantes deste vilarejo, um vilarejo de acolhimento onde teríamos podido entretanto viver uma vida normal 
era estranho ver meu jovem mestre trucidar raízes com incisivos mais cortantes que os de um ser humano ordinário, eu me perguntava até se ele ia consagrar sua adolescência a alimentar-se apenas de bulbos, ele tinha acabado por aceitar a morte do seu pai, viver em Sêkêpembê com Mamãe Kibandí lhes abria outros horizontes, estar longe do Norte tinha também lhes permitido esquecer esse passado, a imagem de um Papai Kibandí neutralizado pelas pessoas de Mossaká com a ajuda do feiticeiro Tembê-Essuká, era claro que a Mamãe Kibandí e o meu mestre desejavam doravante viver uma outra existência, eu ainda me lembro desse período quando eles vieram se instalar aqui, os habitantes os acolheram como teriam acolhido quaisquer estrangeiros, lhes abriram as portas de Sêkêpembê, eles se alojaram numa cabana de tábuas de okumê cobertas por um telhado de palha, digamos que se eles viviam lá para as últimas habitações do vilarejo, era porque não tinha mais terrenos disponíveis no coração de Sêkêpembê, e era preciso achar uma ocupação, o meu mestre se tornou aprendiz de carpinteiro junto a um velho a quem Mamãe Kibandí pagava uma módica quantia de dinheiro, esse velho carpinteiro se tornou quase um pai para Kibandí, este o chamava de "Papai", jamais tinha ousado pronunciar o seu verdadeiro nome, Mationgô, esse homem lhe lembrava o seu próprio pai, sem dúvida por causa da sua estatura curva, da sua aparência de camaleão, "Papai" Mationgô tinha visto no meu mestre um ser inteligente, curioso, Kibandí aprendia rápido as sutilidades da carpintaria, o velho não precisava lhe repetir dez vezes a mesma coisa, ele vinha no entanto alimentando dúvidas quanto a esse aprendiz que, seguindo à risca suas instruções, o espantava todo dia, o jovem homem revisava os métodos obsoletos de "Papai" Mationgô, subia nos telhados com uma habilidade singular, o velho ficou mais que estupefato quando um dia, doente, ele deixou ao meu mestre a tarefa de fazer a estrutura em madeira de uma fazenda, o jovem Kibandí conseguiu fabricar calhas, ripas, diagonais, caibros, telhas, empenas, tesoura, meia tesoura, o que não era dado para qualquer aprendiz, e foi até mesmo o meu mestre que mostrou ao velho como erigir uma estrutura de metal, "Papai" Mationgô só tinha até então trabalhado com estruturas de madeira, tudo se passava na verdade às maravilhas entre os dois humanos, fui eu que vim acordar as suspeitas de "Papai" Mationgô, e eu sei que o velho morreu com a certeza de que o seu aprendiz tinha alguma coisa, me permiti na verdade um dia vagabundear atrás do ateliê, o meu mestre estava ocupado serrando uma tábua, escutei "Papai" Mationgô chegar com o seu passo hesitante, desabotoou a calça, começou a mijar contra a parede do ateliê, e assim que se virou o seu olhar cruzou com o meu, ele agarrou então uma pedra grande que rolava em seus pés e tentou me abater, a pedra aterrissou a poucos centímetros de mim, o velho não tinha mais sua juventude e habilidade, eu corri para o lado do rio, e, alguns instantes depois, ele confiou ao meu mestre que os porcos-espinho de Sêkêpembê não tinham mais medo da gente humana, que existiam muitos deles, que seria preciso que os caçadores se ocupassem disso, que um desses dias ele acabaria abatendo um ele mesmo e o comeria com bananas verdes, jurou então fabricar uma armadilha para isso, Kibandí interrompeu na hora o corte da tábua e lhe respondeu com uma voz calma "Papai Mationgô, não foi um porco-espinho de Sêkêpembê que você viu, acredite em mim", e o velho, de repente duvidoso, o desprezou, balançou a cabeça, deixou correr os braços ao longo do corpo antes de prosseguir com ar resignado "entendi, entendi, meu filho Kibandí, entendi, duvidava um pouco ainda assim, mas não direi nada a ninguém, e de todo modo eu não passo de um rejeitado, um dejeto, não quero problemas com as pessoas antes de partir deste mundo já que vou morrer de um dia pro outro" 
alguns anos mais tarde, antes de partir deste mundo com sua bela morte, "Papai" Mationgô deixou ao meu mestre os seus instrumentos de trabalho, Kibandí teve o sentimento de que o seu próprio pai acabava de morrer pela segunda vez, nesse tempo ele tinha 17 anos, e apesar da sua juventude os telhados não tinham mais segredos para ele, tinha se tornado o artesão mais em vista do pedaço, é a ele que devemos aliás a maior parte das estruturas das novas cabanas de Sêkêpembê, e quando era preciso, geralmente no dia da festa dos mortos, ele ia ao cemitério para se recolher diante da tomba de "Papai" Mationgô, eu o via então soluçar como se se tratasse do seu próprio genitor, eu estava a algumas centenas de metros do cemitério, sabia também que o barulho que vinha de trás era causado pelo outro ele mesmo do meu mestre, eu não me virava com medo de fixar essa criatura sem boca, o outro ele mesmo se excitava cada vez mais, dormia no ateliê, lamuriava ao longo do rio, trepava nas árvores, cheguei a me perguntar como ele se arranjava para comer já que não tinha boca, e, não o tendo jamais surpreendido enquanto fazia uma boquinha, cheguei a deduzir que ou era o meu mestre que comia por ele, ou este outro ele mesmo devia comer por meio de um outro orifício, e eu o deixo adivinhar qual, meu querido Baobá 
a pobre Mamãe Kibandí tinha confeccionado durante doze anos tapetes que ela vendia à população, uma atividade que andava bem, e nos dias de feira nos vilarejos vizinhos como Lubulú, Kimandú, Kinkossô ou Batalêbê, a mãe e o filho iam propor lá suas mercadorias, Kibandí passava as férias nesses cantos perdidos junto às amigas de Mamãe Kibandí, comerciantes como ela, me deixava sozinho com o seu outro ele mesmo, eu não apreciava muito essas ausências que podiam colocar em perigo nossa harmonia, eu não saia do meu esconderijo, me contentava em me alimentar das comidas que o outro ele mesmo do meu mestre me trazia, os dias e as noites passavam assim, os meus pensamentos iam em direção a Kibandí, eu não tinha na verdade nada a temer, estava a par dos seus atos e gestos durante suas ausências de algumas semanas, o outro ele mesmo não me escondia nada, eu soube por exemplo que foi em Kinkossô que o meu mestre tinha experienciado o seu primeiro ato sexual com a famosa Biscurí, uma mulher que tinha o dobro da sua idade, uma viúva cheia de curvas, com um traseiro volumoso e que tinha uma inclinação imoderada pelos novinhos, assim que cruzava com um saltava sobre ele, não o largava mais, era conhecida em Kinkossô por isso, cercava então o novinho, o mimava, lhe preparava o que comer, lhe oferecia sua hospitalidade, alguns pais até encorajavam a viúva Biscurí na sua empreitada, mas ela não apreciava muito que lhe impusessem um novinho, preferia escolher o seu modelo, pouco importava que este fosse magro como o meu mestre, ela tinha uma técnica própria para capturar esses inocentes, fingia primeiro uma conversa do tipo "sua mãe é uma mulher corajosa, é uma das minhas amigas", e abraçava o jovem homem, mergulhava com um gesto repentino sua mão entre as pernas do novinho, agarrava suas partes íntimas antes de exclamar "meu deus, você é bem dotado, você, lhe digo que com isso você começou bem a vida", e ria, retificava em seguida o seu golpe "bom, estava brincando, meu pequeno, vai, venha aqui, vou lhe preparar o melhor prato de Kinkossô, o ngul' mu makô", estimava-se entretanto que Biscurí era a solução menos catastrófica para inculcar a um imberbe as primeiras atitudes sexuais, ora o meu mestre ficou decepcionado com essa experiência, julgou que Biscurí o tinha paralisado com o seu excesso de ardor a ponto de ele ter ficado passivo como se alguém o violasse, pegou hábito depois de frequentar as prostitutas do pedaço, imaginando doravante que a mulher só desempenhava o ato sexual com doçura quando era paga, e quando ia de férias para esses vilarejos o meu mestre quebrava o seu cofrinho de carpinteiro, errava nos bairros sujos, trocava de parceira todas as noites, se embebedava com essas raparigas e voltava a Sêkêpembê com os bolsos vazios, ora Mamãe Kibandí não era besta, suspeitava bem que o meu mestre frequentava doravante as mulheres, esperava um dia ver o seu filho lhe apresentar uma futura enteada ou pessoas vindo bater na sua porta com uma moça grávida

penso também nesse dia em que Mamãe Kibandí surpreendeu o meu mestre sentado diante da porta da cabana lendo a Bíblia, alguém a tinha oferecido a ele em Kinkossô, era um religioso que queria convencê-lo a servir-se das vias do Senhor pois o tinha surpreendido nos bairros das moças de alegria, ${ }^{159}$ sinal de que o meu mestre era uma ovelha extraviada, um pecador que era preciso desviar do caminho do inferno, Kibandí tinha pegado o livro e desaparecido antes que esse servidor de Deus descobrisse que ele era na verdade um analfabeto, e o homem de sotaina não tinha percebido a ajuda que acabava de dar ao meu mestre, este não abriu o livro durante várias semanas, o tinha abandonado na cabeceira da cama a ponto da poeira recobrir já a capa do calhamaço, e uma noite, pego pela insônia, se ocupou enfim dessa bíblia, abriu-a no meio, aproximou-a do nariz, fechou os olhos, inspirou longamente, sentiu o odor agradável da página, e quando reabriu os olhos o brilho da lâmpada iluminava as palavras, as despia do seu enigma, formava ao redor de cada letra uma espécie de halo, e a frase se movimentava, fluía como um rio, ele não soube em que momento os seus lábios começaram a mexer, a ler, também não percebeu que virava rápido as páginas, que os seus olhos iam da esquerda à direita sem que ele tivesse vertigens, as palavras viviam de repente, representavam a realidade, e ele imaginava Deus, e ele imaginava esse vagabundo misterioso que era Jesus, não ia mais parar de ler, e nos dias seguintes não dormia mais, se lançava sobre o livro assim que

${ }^{159}$ Em francês, "filles de joie", um eufemismo para falar das prostitutas. 
voltava do ateliê que tinha erigido atrás da cabana, Mamãe Kibandí não escondeu o espanto, a atitude do filho a divertia, ela se perguntava o que levava o jovem homem a mascarar assim sua ignorância, não bastava ter um livro entre as mãos para mostrar aos outros que era instruído, e ela entendeu isso como brincadeira na medida em que o meu mestre não tinha jamais colocado os pés na escola, não podia então ler, e, um outro dia, cansada dessa nova ocupação do meu mestre, ela espiou o livro que ele percorria, como se pudesse ela mesma devorá-lo, o seu filho parecia concentrado, murmurava as frases, deixava correr o dedo indicador direto sobre as linhas da página, foi sem dúvida nesse dia que ela compreendeu que Kibandí só podia possuir um duplo e que o seu pai o tinha finalmente feito beber o mayamvumbí em Mossaká

o meu mestre não podia mais parar suas leituras, levava doravante para casa toda sorte de livros que comprava nas feiras dos vilarejos vizinhos, os arrumava num canto do ateliê, tinha alguns também no seu quarto, constituía assim uma pequena biblioteca, a maior parte dos livros não tinha mais capa, outros não possuíam nem as primeiras páginas nem as últimas, ele passava horas na biblioteca da igreja Saint-Joseph do vilarejo Kimandú, e, quando não ia ao ateliê ou num vilarejo vizinho para uma obra, ficava o dia todo lendo, foi nessa época que comecei igualmente a distinguir os caracteres que desfilavam nos meus pensamentos, as palavras, era divertido constatar a forma das letras, descobrir que a palavra podia ser gravada em qualquer parte, eu podia a partir desse momento recitar o que lia o meu mestre, me surpreendia várias vezes monologando, e depois, cheguei à conclusão de que os homens se mantinham à frente de nós, os animais, já que eles podiam consignar os pensamentos, a imaginação no papel, foi ainda nesse tempo que a minha curiosidade me levou a sair do meu esconderijo, me introduzi no ateliê do meu mestre enquanto este estava com sua mãe no mercado de Sêkêpembê, me joguei então sobre a pilha de livros, queria ter certeza que eu era capaz de reconhecer essas palavras que flutuavam em meu espírito como pequenas libélulas de asas prateadas, e abri ao acaso as páginas da bíblia que o meu mestre tinha depositado perto dos seus instrumentos de trabalho como para consagrá-los, li vários capítulos, descobri histórias extraordinárias como aquelas que lhe contei no começo das minhas confissões, descobri também outros livros, não tinha necessidade de os ler todos, o meu mestre o faria em meu lugar, retirava-me antes do cair da noite, senão Kibandí e sua mãe me teriam surpreendido, e eu não sei o que teria acontecido então 
é preciso que eu encontre as palavras certas para lhe explicar como Mamãe Kibandí sofria do coração, ela nunca quis que o seu filho estivesse a par dessa doença, o meu mestre só o soube em Sêkêpembê, a doença piorou após nosso décimo segundo ano de residência aqui, Mamãe Kibandí beirava o pior a cada crise, permanecia imóvel durante horas, abria de repente os olhos no momento em que teríamos apostado que ela tinha enfim rendido a alma, ela retinha a respiração, expirava um sopro seco, murmurava palavras do tipo "essa merda de doença não terá a minha vida, ah não, estou sã, os meus ancestrais me protegem, pronuncio todos os dias e todas as noites o nome deles, penso em Kong-Diá-Mamá, em Mukilá-Massengô, em KenguêMukilá, em Mam'Sokô, em Nzambí Ya Mpungú, em Tatá Nzambí, eles me darão um coração novo, um coração que bata mais rápido que a podridão que carrego na minha caixa toráxica", mas o que podiam os ancestrais diante de um coração que patina, desanda, desacelera de ritmo, que podiam eles diante desse músculo vital que tinha se contraído, que só fornecia sangue a uma metade do seu corpo, os ancestrais não podiam nada, meu querido Baobá, podiam a rigor curar uma febre, uma gonorreia, uma bilharziose, uma ferida, uma dor de cabeça, o coração era outro negócio, Mamãe Kibandí sabia disso, se esgotava com o mínimo esforço, não vendia mais os seus tapetes há mais de um ano, o meu mestre, ele também parou de trabalhar, e assim que eu me introduzia no ateliê remarcava as teias de aranha, os livros que tomavam pó, os instrumentos de trabalho guardados num canto, isso queria dizer que Kibandí não subia no cume de uma casa há muitos meses, Mamãe Kibandí o incitava a recomeçar suas atividades, o meu mestre mal a escutava, não ia mais encontrar as prostitutas de Kinkossô, supervisionava de muito perto sua mãe, a fazia beber misturas que, a longo prazo, tinham feito os seus lábios ficarem corados, Kibandí não saiu mais da cabana até o dia em que sua mãe foi se juntar a Papai Kibandí no outro mundo, ora várias semanas antes, como se ela estivesse sabendo da data e da hora exatas da sua viagem, sem dúvida porque ela se espantava com o comportamento estranho do seu filho que de repente era um leitor assíduo, diríamos um verdadeiro letrado, ela relembrou ao meu mestre de não lhe desobedecer, de não seguir o caminho do defunto Papai Kibandí correndo o risco de acabar um dia como ele, e o jovem mestre fez a promessa, jurou três vezes em nome dos ancestrais, a mentira era grande, sem dúvida teria valido mais a pena lhe dizer a verdade pois no instante em que jurou sobre a cabeça dos antepassados um dos peidos mais sonoros que ele já tinha liberado escapou da sua bunda, eles tiveram, a moribunda e ele, de tapar as narinas, um fedor de cadáver se alastrou no cômodo a ponto de eles deixarem a porta e as janelas abertas trinta dias e trinta noites, a catinga só se dissipou no dia da morte da velha, essa segunda acinzentada, uma segunda na qual até mesmo as moscas tinham dificuldade de voar, Sêkêpembê parecia deserta, o céu estava baixo, tão baixo que um ser humano podia arrancar de lá alguns pedaços de nuvem sem levantar o braço, e depois, por volta das onze horas da manhã, uma trupe de carneiros esqueléticos vindos de não se sabe onde deram a volta no ateliê do meu mestre, pararam diante da sua cabana, cobriram o pátio de excrementos diarreicos antes de se orientar em fila indiana em direção ao rio após o mais velho entre eles soltar um lamento de animal degolado no matadouro, Kibandí correu para o quarto da sua mãe, descobriu-a inanimada, os traços do rosto contraídos, a mão direita pousada sobre o seio esquerdo, sem dúvida ela tinha contado os últimos batimentos do seu coração antes de fechar os olhos para sempre, o meu mestre correu por toda Sêkêpembê como um louco para anunciar o acontecido, Mamãe Kibandí foi enterrada num lugar reservado aos estrangeiros, tinha algumas pessoas presentes durante $o$ funeral, mas não muitas pois ela e o seu filho eram ainda tidos pelos aldeões como "pessoas vindas de fora, saídas do ventre da montanha" ainda que residissem lá há muito tempo, e, meu querido Baobá, segundo o que sei, conhecer o passado é essencial para a aproximação dos homens, não é como o que constatei nesse nosso mundo, ainda que um grupo de animais bem estabelecido veja com maus olhos a invasão de uma besta estrangeira, sei por experiência que os animais são também organizados, têm o seu território, governante, rios, árvores, trilhas, não são só os elefantes que possuem um cemitério, todos os animais se apegam ao seu universo, ora no caso dos primos-irmãos do macaco, é bizarro, um vazio, uma sombra, uma ambiguidade sobre o passado engendra a desconfiança, quiçá a rejeição, é por isso que não tinha muitos habitantes no enterro de Mamãe Kibandí cujo corpo ficou três dias e três noites sob um hangar de folhas de palmeira construído pelo meu mestre perto do seu ateliê 
meu querido Baobá, gostaria que você guardasse ao menos de Mamãe Kibandí uma imagem de mulher corajosa, uma mulher que amava o seu filho, uma mulher humilde que viveu neste vilarejo, uma mulher que amou este vilarejo e que passava dias inteiros tecendo tapetes, uma mulher que talvez não encontrará o sono no outro mundo porque o meu mestre não cumpriu a sua palavra, Kibandí ia agora viver sozinho aqui, decidiu retomar a sua profissão de carpinteiro, eu me arrastava perto do seu ateliê, o escutava manejar os instrumentos com raiva, serras as tábuas com ímpeto, o via partir para o vilarejo vizinho, trabalhar num canteiro, voltar à noite, se estatelar na cama, abrir as páginas de um livro, e nessa cabana silenciosa podíamos adivinhar a sombra de Mamãe Kibandí, sobretudo quando um gato miava muito tarde da noite ou um fruto tombava no rio, o outro ele mesmo do meu mestre me visitava cada vez mais, se virava de costas para mim como de costume, eu percebia uma silhueta triste, perdida, sabia agora que nós estávamos próximos, muito próximos do início das nossas atividades, podíamos doravante começá-las, Mamãe Kibandí não estando mais aqui para que o meu mestre sentisse ainda algum receio 
eu queria lhe falar desse dia em que Kibandí tinha retornado do túmulo da sua mãe, esse dia em que decidi ir dar uma volta ao redor da sua cabana lá pelas dez horas da noite, o outro ele mesmo do meu mestre tinha me assombrado durante a tarde toda, eu o escutava correr por todo lado, revirar a vegetação, mergulhar no rio, desaparecer um momento, voltar meia hora mais tarde, eu sabia que esse outro ele mesmo me enviava uma mensagem, a hora da nossa primeira atividade tinha então chegado, eu me agitava em meu esconderijo, não parava mais no lugar, Kibandí queria me ver, me sentir, e então, chegando perto do ateliê quando a noite estava tão escura que eu não via mais longe que a ponta do meu focinho, constatei que não tinha luz na cabana, normalmente o meu mestre lia até bem tarde da noite, remarquei também que a porta estava semiaberta, pude entrar discretamente para descobrir Kibandí deitado sobre o último tapete que sua mãe tinha tecido, um tapete semiacabado e do qual ele gostava mais que tudo, comecei a roer suas unhas, a roer também os seus calcanhares, como ele apreciava esses gestos de afeição ele acordou, se pôs de pé, eu o vi se vestir, virar de costas para mim para que eu não visse o seu sexo, e foi atravessando o pequeno cômodo que servia de sala que eu trombei com o seu outro ele mesmo dormindo no chão, saímos da cabana enquanto o outro ele mesmo se deslocava para ir se deitar sobre o último tapete tecido por Mamãe Kibandí, eu andava com as patas posteriores atrás do meu mestre que avançava com os olhos meio fechados, diriam ser um cego, e chegamos a algumas centenas de metros da concessão do pedreiro Papai Lubotô, o meu mestre se sentou ao pé de uma mangueira, eu o vi estremecer, falar sozinho, tocar a barriga como se sentisse dor, "vai lá agora, é sua vez", me disse ele, mostrava com o dedo a cabana do outro lado da concessão, e como eu hesitava ele repetiu sua ordem de maneira mais autoritária, me conformei, e uma vez atrás da cabana descobri um buraco profundo, sem dúvida obra dos roedores dos arredores, eu o usei sem tergiversar, cai no quarto de dormir da filha de Papai Lubotô, a jovem Kiminú, era uma adolescente de pele clara, rosto redondo, contavam que era a mais bela menina de Sêkêpembê, quatro pretendentes tinham apresentado sua candidatura de casamento ao pai e só esperavam o ano seguinte quando a menina se tornaria maior e Papai Lubotô exprimiria sua escolha definitiva, a jovem Kiminú estava diante de mim, eu contemplei por um momento sua beleza, o pano mal recobria o seu quadril, o seu peito estava ao meu alcance, senti uma espécie de desejo violento, urgente, tive medo das minhas próprias partes genitais, eu que nunca fiz baixaria com nenhuma fêmea, nem mesmo com uma da minha própria espécie, juro, aliás isso não tinha em momento algum me incomodado, não pensava nisso ao contrário de certos membros do nosso grupo na época em que se entregavam a essas coisas baixas quando o velho governante nos dava as costas, eles eram mais velhos que eu, esses companheiros, e depois veja só no dia dessa primeira missão vi uma excrescência repentina entre as minhas patas de trás, o meu sexo que endurecia, eu tinha até então acreditado que ele só servia para mijar assim como meu reto só servia para defecar, fiquei com vergonha, e juro que não sei até agora o que eu poderia ter feito se me encontrasse diante de um porco-espinho do sexo oposto que avançaria sobre mim ou me chamaria com a pata nesse sentido, talvez eu deva a minha virgindade a meu destino de duplo, e quando os outros membros da nossa comunidade fornicavam com as fêmeas tudo acontecia para mim como se eu assistisse a uma cena imunda, era laborioso, mas eles chegavam ao fim, gritavam, gemiam, se agarravam aos espinhos das suas parceiras, eu me perguntava então o que eles sentiam quando gesticulavam desse jeito como se estivessem acometidos por epilepsia, e além disso, lhe digo, o barulho que causavam as esfregações dos seus espinhos me aborrecia, ora os companheiros pareciam ter prazer antes de soltar um longo estertor e cair num estado de atordoamento tal que mesmo um bebê que ainda mija no berço podia capturá-los com as próprias mãos, e então, foi no dia dessa primeira saída que eu descobri que, se meu sexo continuava indiferente aos atrativos de um porco-espinho fêmea, ele reagia logo à vista da nudez de um ser humano do sexo feminino, a minha missão não consistia entretanto em tentar alguma experiência com essa moça, é por isso que depois de ter tergiversado eu varri essas ideias que me atravessavam o espírito, disse a mim mesmo que eu não era feito para essas coisas, que essas coisas se praticavam entre membros de uma mesma espécie, e então, a fim de afastar melhor essas ideias da minha cabeça, pensei em outra coisa, no 
objetivo da minha missão, me perguntei o que tinha levado o meu mestre a se interessar à bela Kiminú, sem dúvida por causa desse corpo de silhueta perfeita, e, uma vez mais, eu afastei com um movimento de pata esses questionamentos com medo de ser fraco no momento em que ia passar à ação, mas no fundo, ainda que me esforçasse para esvaziar o cérebro, me colocava entretanto a refletir, e me lembrei que Kibandí fazia parte dos quatro candidatos ao casamento, o seu pedido tinha feito o vilarejo rir tanto que o meu mestre se arrependeu do ato, eu o vi discutir duas ou três vezes com esse Papai Lubotô perto da praça do mercado, um dia eles tinham bebido vinho de palma juntos, esse tipo tinha falado com emoção de Mamãe Kibandí, tinha dito "é uma boa mulher, mesmo depois de anos e de anos todo o vilarejo se lembrará dela, acredite em mim, pode se orgulhar dela, e eu sei que ela o protege", não existia nenhuma sinceridade na sua voz, além do mais Kibandí se lembrava ainda que Papai Lubotô não tinha ido ao funeral da sua mãe, então ele fingia ser gentil em relação ao meu mestre com a esperança de receber presentes de um apaixonado cujo pedido ele rejeitaria assim que o momento chegasse, e depois, quando todos esses candidatos tinham terminado de conversar com o potencial sogro, cada um deles partia com a convicção de ser o homem da situação, o marido a quem Papai Lubotô daria sua filha de olhos fechados, ora o meu mestre não era bobo, sabia que não teria a menor chance, dava entretanto a esse trapaceiro tudo o que possuía, tudo o que sua mãe lhe tinha legado, tapetes de festividades, cestos de noz de palma, suas economias de carpinteiro, ele tinha também refeito o telhado desse homem sem lhe cobrar um centavo, e podíamos ler no olhar de Papai Lubotô uma espécie de espera inextinguível, ele se vangloriava no vilarejo, era ele que relatava que Kibandí era feio como um percevejo, magro como um prego de moldura de foto, acrescentava que uma mulher digna desse nome não aceitaria jamais o pedido do meu mestre que podia sempre sonhar, que ele ia arruiná-lo, tirar-lhe até suas cuecas samba-canção, suas roupas de baixo, suas sandálias de borracha, sem dúvida foram a frustração e a revolta que tinham conduzido o meu mestre a querer se ocupar dessa família pois, devo precisar isto, meu querido Baobá, para que um ser humano coma um outro é preciso ter razões concretas, o ciúme, a cólera, o desejo, a humilhação, a falta de respeito, juro que nós não comemos em nenhum caso alguém apenas pelo prazer de comê-lo, e então, nessa noite memorável, a jovem Kiminú dormia como um anjo, tinha os braços cruzados sobre o peito, respirei um pouco antes de armar um dos meus espinhos mais firmes, depois projetá-lo por inteiro sobre sua têmpora direita, ela não teve tempo de perceber o que lhe acontecia, lancei de novo um outro espinho, ela tremeu, se debateu em vão, estava paralisada, me aproximei dela, a escutei murmurar palavras sem pata nem cabeça, pus-me então a lamber o sangue que pingava da sua têmpora, vi como por encantamento desaparecer o buraco deixado pelos meus dois espinhos, e não teria então nenhum traço visível para aqueles que não fossem dotados de quatro olhos, dei uma volta no outro quarto onde dormiam os pais da jovem moça, o pai ronronava como um automóvel velho, a mãe tinha o braço esquerdo caindo da cama, eu não tinha como missão me ocupar deles, afastei então a voz que me sussurrava para projetar dois ou três espinhos nas têmporas do pai e da mãe de Kiminú

no dia seguinte, o estupor ganhou Sêkêpembê inteira, Kiminú estava mesmo morta, se concordavam que ela tinha sido comida, falava-se antes de uma rivalidade entre as linhagens materna e paterna da defunta, teve uma briga entre essas duas linhagens, pegaram as machetes, zagaias, picaretas, o chefe de Sêkêpembê conseguiu apaziguar os dois lados, propôs de proceder no dia do funeral a famosa prova do cadáver que detecta o seu malfeitor, Kibandí contava um pouco com isso, meu querido Baobá, consequentemente ele se preparou, Papai Kibandí tinha lhe ensinado como contornar essas coisas, o meu mestre tinha então enfiado uma noz de palma no seu reto como na época em que o seu genitor tentou enganar a vigilância do feiticeiro Tembê-Essuká, e o cadáver da jovem Kiminú foi antes designar como culpado um dos outros candidatos ao casamento, esse pobre inocente que enterraram vivo junto com a defunta, sem outra forma de processo, porque era usual

meu querido Baobá, a prova do cadáver que detecta o seu malfeitor é temida por todo o mundo, é um rito propagado na região, cada vez que tem um morto aqui os aldeões se apressam 
para recorrer a ele, não existe morte natural no espírito deles, só o defunto pode dizer aos vivos quem esteve na origem do seu desaparecimento, você quer sem dúvida saber como as coisas se passam, pois bem, quatro valentões carregam o caixão sobre os ombros, um feiticeiro designado pelo chefe do vilarejo segura um pedaço de madeira, bate três vezes sobre o caixão e pergunta ao cadáver "nos diga quem o comeu, mostre em qual cabana este malfeitor habita, você não pode ir embora assim para o outro mundo sem se vingar, então, ande, corra, voe, atravesse montanhas, planícies, e se o malfeitor habita para além do Oceano, e se ele habita com as estrelas, nós iremos até ele para que pague pelo mal que lhe fez a você e a sua família”, o caixão começa de repente a se mexer, os quatro valentões que o seguram sobre o ombro são como que arrastados para uma dança endiabrada, não sentem mais o peso do cadáver, correm da esquerda para a direita, com frequência o caixão os leva para o meio da savana, os traz ao vilarejo numa corrida vertiginosa, e os valentões andam sobre espinhos, sobre cacos sem sentir dor, sem se machucar, penetram na água sem se afogar, atravessam as queimadas da savana sem se queimar, e aliás uma vez os Brancos vieram aqui para observar essa prática em vista de contá-la num livro, se apresentaram como sendo etnólogos, tinham dificuldade de explicar a certos brutamontes de Sêkêpembê para quê servia um etnólogo, eu, eu ri bastante pois, para ir mais rápido, palavra de porco-espinho, eu teria dito a esses imbecis que os etnólogos são pessoas que contam coisas sobre os costumes dos outros homens que eles consideram como curiosidades em relação a sua própria cultura, é isso, mas um dos Brancos se arriscou a demonstrar aos pobres perdidos de espírito deste vilarejo que a palavra "etnologia" vinha do grego ethnos e queria dizer "povo", então os etnólogos estudavam os povos, as sociedades, os seus costumes, a sua maneira de pensar, de viver, ele precisou que se a palavra "etnólogo" incomodava alguns, podiam simplesmente dizer "antropólogo social", o que tinha ainda semeado a confusão, e continuaram antes a pensar que eles eram uns sem-emprego em seu país ou que vinham colocar antenas parabólicas no vilarejo a fim de supervisionar as pessoas, e então eles chegaram aqui, esses Brancos etnólogos ou antropólogos sociais, tinham esperado que alguém morresse, e para a sorte deles um indivíduo tinha sido comido aqui, não pelo meu mestre, mas por um outro tipo que tinha como duplo nocivo o musaranho, os etnólogos disseram em coro "maravilha, nós temos nossa morta, ela está do outro lado do vilarejo, o enterro é amanhã, vamos enfim terminar essa merda de livro", e pediram para levar eles mesmos o caixão sobre os seus ombros porque estavam persuadidos de que alguma coisa não descia redondo nessa prática, que na verdade eram os valentões encarregados de levar o caixão que o remexiam com o intuito de acusar a torto e a direito as pessoas, mas a questão da participação dos Brancos nesse rito dividiu o vilarejo, alguns feiticeiros não desejavam que estrangeiros se misturassem aos assuntos de Sêkêpembê, finalmente o chefe do vilarejo foi diplomata, jurou que os ritos dos ancestrais funcionariam mesmo na presença dos Brancos pois os ancestrais do vilarejo são mais fortes que os Brancos, e convenceu todo o mundo que era uma sorte que essas pessoas vindas de fora participassem da prova, além do mais eles falariam de Sêkêpembê no seu livro, o vilarejo seria conhecido no mundo inteiro, vários povos de outros territórios se inspirariam nesses costumes para a glória dos antepassados, e o descontentamento se dissipou, se transformou em orgulho coletivo, quase teve briga quando chegou a hora de escolher entre os doze feiticeiros do vilarejo aquele que supervisionaria o rito, todos queriam agora trabalhar com os Brancos enquanto tal ideia era inadmissível algumas horas antes, e cada feiticeiro se gabava doravante da sua árvore genealógica, ora só era preciso um entre eles, o chefe do vilarejo reuniu doze cauris, marcou uma pequena cruz sobre um deles, os colocou num cesto, os remexeu e pediu a cada feiticeiro para fechar os olhos antes de afundar a mão dentro e tirar um cauri por acaso, aquele que pegasse o cauri marcado teria a honra de dirigir o rito, o suspense foi até o décimo-primeiro cauri que um feiticeiro que postergava sem parar o seu turno tirou sob o olhar invejoso dos seus colegas, e então, ao fim dessas negociações, os etnólogos ou antropólogos sociais suspenderam enfim o caixão diante das gargalhadas dos aldeões que não temiam mais humilhar o cadáver deles ao exibir tal hilaridade, e o feiticeiro, retendo ele também um riso louco, deu três golpes secos com a ajuda do seu pedaço de madeira, teve dificuldade em achar as palavras a fim de suplicar ao cadáver de ir designar o seu malfeitor, mas o morto compreendeu o que esperavam dele visto que, no seu discurso, o feiticeiro acrescentou "não nos faça sobretudo passar vergonha diante desses Brancos que vieram de longe e que observam nossos costumes pela simples 
diversão", não foi preciso pedir duas vezes, uma chuvinha começou a cair, e quando o caixão se pôs a mexer para frente com pequenos saltos de bebê canguru, os etnólogos que estavam atrás gritaram "mas digam então queridos colegas, parem de mexer essa merda de caixão, o deixem se deslocar se é que ele pode de verdade se deslocar, merda", e os outros etnólogos lhes responderam "parem de brincadeira, gente, são vocês que o estão mexendo, merda", o cadáver se excitou, acelerou o ritmo, arrastou os antropólogos sociais para uma plantação de lantanas, os trouxe de volta ao vilarejo, os empurrou até o rio, os trouxe de novo para o vilarejo antes de parar sua corrida desenfreada diante da cabana do velho Mubungulú, e, pegando impulso, o caixão derrubou a porta da cabana, penetrou no interior da moradia do culpado, um velho musaranho que fedia como um gambá escapou da habitação, rodopiou em volta dele mesmo no meio do pátio, foi direto em direção ao rio, o caixão o alcançou antes do primeiro arbusto, se jogou sobre ele, foi assim que morreu o velho Mubungulú, meu querido Baobá, e parece que esses Brancos escreveram um livro grosso com mais de novecentas páginas para contar essa história, eu não sei se o vilarejo de Sêkêpembê se tornou célebre no mundo inteiro, é verdade que tiveram outros Brancos que passaram por aqui só para verificar o que os primeiros tinham escrito no livro, vários entre eles partiram de mãos vazias pois os habitantes dotados de duplos nocivos desconfiavam deles, e depois tudo se passava como se as pessoas não morressem mais desde que chegavam Brancos nos arredores, acontecia que alguns cadáveres rejeitavam o rito, se recusavam a jogar o jogo ou que alguns aldeões deixavam como último desejo as suas famílias de sobretudo não submeter o seu cadáver a esse rito na presença de Brancos que perigavam atenuar a reputação deles no mundo inteiro, você compreende então que essa tradição seja agora praticada com muita prudência aqui, mas no fundo, lhe digo, meu querido Baobá, a razão mais crível vem de um tipo que chamamos de Amêdê, se eu falo dele no passado, é porque ele não está mais neste mundo, paz à sua alma, ele era o que os humanos chamam de um letrado, um homem culto, tinha feito longos estudos, respeitavam-no por isso, além do mais ele tinha viajado muito, subiu várias vezes no avião, esse pássaro barulhento que rasga o céu e esquece toda vez de refazer o teto, parece que Amêdê era o mais inteligente dos tipos do Sul, para não dizer do país inteiro, pois bem, nós o tínhamos ainda assim comido como você saberá logo, foi então ele que tinha pretendido que o livro que os primeiros Brancos tinham escrito sobre essa questão tinha sido publicado na Europa e sido traduzido em várias línguas, afirmava que essa obra tinha se tornado uma referência incontornável para os etnólogos, e Amêdê que o tinha lido não tinha economizado críticas, "nunca antes li tal impostura, o que lhes dizer além disso, hein, é um livro vergonhoso, é um livro humilhante para as sociedades africanas, é um emaranhado de mentiras por parte de um grupo de europeus em busca do exotismo e que desejam que os Negros continuem a se vestir com peles de leopardos e a habitar nas árvores" 
a brisa se eleva agora, suas folhas caem em cima de mim, é uma sensação agradável, esses pequenos detalhes me permitem doravante apreciar a alegria de viver, e quando eu olho para o céu penso que você teve uma santa sorte, você, de viver num lugar paradisíaco, tudo é verde aqui, você está sobre uma colina, domina a vizinhança, as árvores ao redor se curvam enquanto você contempla os humores do céu com a indiferença de quem já viu tudo durante sua existência, as outras espécies vegetais parecem anões de jardim ao seu lado, você governa com o olhar a flora inteira, eu escuto o rio correr desde aqui, desembocar nos rochedos um pouco mais abaixo, raras são as pessoas de Sêkêpembê que se aventuram nesses lugares, elas abateriam todas as espécies dessa savana, não o tocariam jamais graças ao respeito que os aldeões devotam aos Baobás, sei que isso não foi sempre assim, sei que disseram coisas a seu respeito, posso lê-las através das nervuras da sua casca, algumas são cicatrizes, tiveram uns loucos do vilarejo que tentaram pôr fim aos seus dias, e com sua loucura destrutiva, palavra de porco-espinho, quiseram reduzi-lo a lenha, acreditaram que você bloqueava o horizonte, que escondia a luz do dia, e eles não conseguiram pois a serra deles se dobrou diante da sua resistência legendária, e depois se contentaram com as okumês que utilizam como tábuas para fabricar ao mesmo tempo caixões e casas, essa madeira que o meu mestre utilizava para edificar as estruturas, e existem aldeões que pensam que você é dotado de uma alma, que você protege a região, que o seu desaparecimento seria prejudicial, fatal para o território, que sua seiva é tão sagrada quanto a água benta da igreja do vilarejo, que você é o guardião da floresta, que você sempre existiu desde os tempos mais remotos, é talvez por isso que os feiticeiros utilizam sua casca para curar os doentes, outros afirmam que falar com você é se dirigir aos antepassados, "senta-te ao pé de um baobá e, com o tempo, verás o Universo desfilar diante de ti", nos dizia às vezes nosso velho porco-espinho, este que relatava que antigamente os baobás podiam falar, responder, punir, chicotear os humanos com a ajuda dos seus galhos quando os primos-irmãos do macaco se uniam contra a flora, e nesse tempo, prosseguia ele, os baobás podiam se deslocar de um lugar a outro, escolher um ambiente mais confortável a fim de melhor se enraizar, alguns entre eles vinham de longe, de muito longe, cruzavam com outros baobás que iam na direção oposta pois temos sempre tendência a acreditar que a terra estrangeira é melhor que aquela que nos viu nascer, que a vida é mais suportável alhures, e eu, eu fico imaginando essa época de grande errância, essa época na qual o espaço não era um obstáculo, hoje ninguém daria crédito aos discursos do nosso governante, qual homem inflado de razão, entupido de preconceitos imaginaria que uma árvore cujas raízes estão implantadas de uma vez por todas na terra poderia se deslocar, hein, o homem incrédulo retrucaria logo "e por que não as montanhas já que estamos sobre elas, hein, elas podem também passear, as montanhas, se agarrar umas às outras num cruzamento, discutir sobre a chuva e sobre o bom tempo, trocar endereços, informar as novidades das respectivas famílias, são trivialidades tudo isso", eu, eu acredito nisso, dessa vez dou razão a nosso governante, não são lendas, não são trivialidades que ele nos contou, ele tinha razão, e eu sei que você também, você deve ter se deslocado, deve ter fugido dos territórios ameaçados pelo deserto, das regiões onde chove a conta-gotas, você abandonou sua família, se aproximou das zonas chuvosas, e não é um acaso se você escolheu o lugar mais fértil desse país, eu ignoro se existe um outro baobá nos arredores, gostaria muito de remontar a sua genealogia, saber de qual árvore você descende e em qual lugar viveram os seus primeiros antepassados, mas talvez eu esteja me distanciando um pouco das minhas próprias confissões ao falar de você, hein, é ainda a minha parte humana que se exprimiu, na verdade eu aprendi com os homens o sentido da digressão, eles não vão jamais direito ao assunto, abrem parênteses que se esquecem de fechar 
eu não gosto desse tipo de homem como esse jovem letrado que chamavam de Amêdê e que nós tínhamos comido, ele mal tinha chegado aos trinta, e era ele que tinha lido o livro que os etnólogos ou antropólogos sociais tinham escrito sobre a prática do cadáver que detecta o seu malfeitor, lhe digo isso porque se tem um ser do qual eu não lamento nem mesmo o desaparecimento, é esse jovem homem, ele era pretencioso, um olhem-para-mim de primeira classe que se achava o mais inteligente deste vilarejo, desta região, quiçá deste país, usava roupas de tergal, gravatas cintilantes, sapatos de quem trabalha em escritório, esses lugares de preguiça onde os homens se sentam, fingem ler uns papéis, deixam para amanhã o que é preciso fazer no mesmo dia, Amêdê andava com o peito estufado, simplesmente porque tinha feito longos estudos, simplesmente porque tinha estado em países onde neva, lhe digo que assim que ele chegava em Sêkêpembê para visitar a família as moças jovens fogosas corriam atrás dele, até mesmo as moças casadas enganavam os seus esposos, lhe levavam comida escondida atrás da cabana do seu pai, lavavam sua roupa suja, o tipo conseguia fazer essas safadezas por todo lado com essas damas casadas e essas jovens fogosas, ele as fazia no rio, na mata, nas plantações, atrás da igreja, perto do cemitério, eu não acreditava no que via, é verdade que ele era bonito, atlético, passava aliás o seu tempo mantendo essa beleza com gestos de um ser humano do sexo feminino, jamais tínhamos visto um tal coquetismo neste vilarejo, e quando ele ia se banhar no rio se mirava durante muito tempo, se cobria de essências perfumadas, olhava com satisfação sua imagem se refletir sobre a onda calma e quase cúmplice desse coquetismo, então Amêdê pensava que era bonito, muito bonito, e um dia ele quase se afogou pois, a fim de melhor contemplar a sua silhueta inteira, tinha posto os pés sobre uma pedra recoberta de musgo, e opa, palavra de porco-espinho, tropeçou, acabou na água, mas, graças a Deus para ele, ele sabia nadar e voltou para a outra margem em dois tempos três movimentos, riu como um cretino, os banhistas o aplaudiram, e para celebrar esse dia no qual ele escapou por pouco da morte ele colheu um hibisco vermelho, o jogou no rio, o viu seguir a corrente, desaparecer num entrelaçamento de samambaias e nenúfares, é por isso que as pessoas deste vilarejo não dizem mais "hibisco vermelho" ao falar dessa flor, eles a chamam de "a flor de Amêdê"

o pior é que Amêdê criticava em voz alta o comportamento das pessoas idosas, as tratava de velhos bestas, ignorantes, idiotas, só os seus próprios pais eram poupados pois, dizia ele, se os seus pais tivessem tido a sorte de ir para a escola, eles teriam sido tão inteligentes quanto ele já que ele lhes devia sua inteligência, e quando o dia se levantava nosso pretencioso se sentava ao pé de uma árvore, lia livros espessos escritos em letras miúdas, a maioria romances, oh você com certeza nunca viu um romance, talvez ninguém tenha vindo ler um ao seu pé, você não perdeu nada, meu querido Baobá, mas para simplificar as coisas e não lhe poluir o espírito, direi que os romances são livros que os homens escrevem com o objetivo de contar coisas que não são verdadeiras, eles fingem que isso vem da imaginação deles, existem entre esses romancistas alguns que venderiam a mãe ou o pai para roubar meu destino de porcoespinho, eles se inspirariam nisso, escreveriam uma história na qual eu não teria sempre o melhor papel e passaria por um animal de maus modos, lhe asseguro que os seres humanos se entediam tanto que precisam desses romances para se inventar outras vidas, e nesses livros, meu querido Baobá, mergulhando neles, podemos percorrer o mundo inteiro, sair da savana num piscar de olhos, nos encontrar em terras longínquas, podemos cruzar povos diferentes, animais estranhos e mesmo porcos-espinho que têm um passado mais comprometedor que o meu, eu ficava constantemente intrigado quando me escondia num arbusto para escutar Amêdê falar às jovens moças de coisas que existiam nesses livros dele, e as moças o olhavam com mais respeito e consideração porque, para esses primos-irmãos do macaco, quando lemos muito, temos o direito de nos vangloriar, de julgar os outros como pior que nada, e essas pessoas que leram muito falam sem parar, citam sobretudo coisas contidas nos livros mais difíceis de compreender, querem que os outros homens saibam que eles leram, Amêdê contava então a essas pobres jovens o infortúnio de um velho que ia pescar em alto mar e que devia lutar sozinho contra um grande peixe, esse peixe era a meu ver um duplo nocivo de um pescador invejoso do velho e da sua experiência, nosso jovem homem letrado falava também de um outro velho que amava ler romances de amor e que ia ajudar um vilarejo a neutralizar uma fera que 
semeava o terror em toda a região, estou certo de que essa fera era um duplo nocivo de um aldeão desse país longínquo, foi também Amêdê quem contou a eles várias vezes a história de um garoto que se deslocava num tapete voador, de um patriarca que criou um vilarejo chamado Macondo e cuja descendência ia afundar numa espécie de maldição, nascer meio-homem meioanimal, com focinho, rabo de porco, estou persuadido de que devia também se tratar de histórias de duplos nocivos, e, até onde me lembro, ele contava as aventuras de um tipo bizarro que combatia o tempo todo os moinhos de vento, ou ainda, na mesma ordem de ideias, o infortúnio de um oficial que esperava em vão por reforço num acampamento perdido no deserto, e o que dizer desse velho coronel que esperava uma carta e sua pensão de antigo militar, esse infeliz coronel que vivia na privação com sua esposa doente e o seu galo de briga no qual colocavam todas as esperanças, esse galo era a única alegria deles, esse animal devia ser um duplo pacífico, por isso não insisto, e então, para botar medo nas moças, porque essas moças amavam sentir arrepios, escutar histórias de estupro, de sangue, de morte, Amêdê lhes contava sobre um gangster impotente que tinha cometido um estupro com a ajuda de uma espiga de milho num canto perdido do sul da América, ele não deixava de lhes dizer na sequência a história trágica de um duplo assassinato numa rua chamada bizarramente de "Morgue", e como se tratava de uma mulher estrangulada, introduzida à força numa chaminé de cabeça para baixo, as moças soltavam gritos de horror quando Amêdê acrescentava que atrás do prédio onde tinha ocorrido esse drama, num pequeno pátio, jazia um outro cadáver de uma velha senhora, a garganta cortada, a cabeça arrancada, e algumas moças saíam às vezes da assembleia, só voltavam depois que Amêdê tinha elucidado o mistério desse assassinato crapuloso retomando as análises perspicazes do investigador, mas na realidade a história que dava reais arrepios a essas moças era aquela de uma mulher muito bela que chamavam de Alícia, e em certos aspectos eu tinha pensado que Amêdê tirava sarro do meu mestre Kibandí ao falar dele disfarçadamente, o jovem homem dizia com frequência "após o mundo de Edgar Alan Poe, vou levá-los longe, ao Uruguai, para Horacio Quiroga", Amêdê descrevia então com deleite o personagem de Alícia, ensinava a eles que ela era loira, angelical, tímida, as moças soltavam uns "ooohhh" intermináveis, o homem culto acrescentava que Alícia era uma mulher apaixonada pelo seu esposo Jordan de caráter entretanto muito rígido, os dois se amavam apesar dos seus temperamentos opostos, caminhavam de braços dados, o casamento deles só iria durar três meses, existia a fatalidade, o céu de outono enuviava doravante o idílio deles, um pouco como uma espécie de maldição que invejava a união, tudo isso se fragilizou ainda mais devido a uma pequena gripe que se estendia, Alícia sofria, continuava de cama, emagrecia dia após dia, a vida parecia escapar dela, nada mais era como antes apesar dos cuidados de Jordan, e nesse estado do seu relato, assim que Amêdê descrevia o cenário da casa do casal, o frisson não estava longe, a alegria se transformava em angústia, escutavam Amêdê falar com sua voz mais grave, descrever o lar do casal Jordan e Alícia, "dentro, o brilho glacial do estuque, sem uma única e superficial fissura nas altas paredes, corroborava a desconfortável sensação de frio", e ele lia ainda, alguns parágrafos depois, "na passagem de uma peça para outra, os passos ecoavam em toda a casa, como se um longo abandono lhe tivesse aguçado a ressonância", ninguém sabia do que Alícia sofria, vários médicos desistiram, tinham tentado toda sorte de medicamento sem sucesso, Alícia morreu finalmente, e, depois da sua morte, a empregada entrou para desfazer a cama, descobriu com estupefação duas manchas de sangue sobre o travesseiro de penas que suportava a cabeça de Alícia, a empregada tentou levantá-lo, e como surpreendentemente o travesseiro de penas pesava, ela solicitou a ajuda do jovem viúvo Jordan, eles o colocaram sobre a mesa, Jordan começou a seccioná-lo com a ajuda de uma faca, "as penas à superfície voaram, e a criada, com a boca escancarada, deu um grito de pavor, levando as mãos crispadas aos bandós", lia Amêdê com um ar sombrio e aplicado, e já que as moças de Sêkêpembê ainda não compreendiam o que Jordan e sua empregada tinham descoberto nesse travesseiro de penas, Amêdê revelava enfim o mistério pronunciando com insistência cada palavra, "no fundo, entre as penas, movendo lentamente as patas peludas, havia um animal monstruoso, uma bola vivente e viscosa", e é esse animal que, em cinco dias e cinco noites, tinha sugado o sangue de Alícia com a ajuda da sua tromba, e eu, do meu lado, me dizia que essa Alícia era talvez uma iniciada, um ser humano que tinha sido comido por seu próprio duplo nocivo retraído nesse travesseiro de penas 
o meu mestre me confiou um dia "sabe, precisamos dele, desse jovem homem, porque ele não se acha um merda, ele conta besteiras às pessoas, parece que ele diz que eu estou doente e que existe uma besta que me come toda noite", e nós esperamos as férias da estação seca quando o jovem homem voltava da Europa com suas caixas de romances, depois um dia Amêdê passou diante da casa do meu mestre, viu Kibandí sentado do lado de fora com um livro esotérico entre as mãos, Amêdê disse "caro senhor, estou contente de saber que o senhor lê de tempos em tempos", o meu mestre não respondeu, o jovem homem emendou "se não me engano, o senhor me parece bem magro e me lembra um infeliz personagem dos Contos de amor, de loucura e de morte, e cada ano isso vai de mal a pior pro senhor, não é nem mesmo a perda da sua mãe que o coloca nesse estado, hein, eu insisto em aconselhá-lo a consultar um médico da cidade, espero que não haja uma besta escondida sob o seu travesseiro e que se nutre do seu sangue com ajuda da sua tromba, se é o caso, ainda há tempo para queimar esse travesseiro, matar a besta que se esconde lá dentro", o meu mestre não retrucou uma vez mais, achou mesmo que o intelectual do vilarejo delirava, acreditava que as pessoas eram personagens dos livros que tinha trazido da Europa, e Kibandí prosseguiu a leitura do seu livro que falava de coisas mais importantes do que aquelas que são contadas nos livros de Amêdê, e quando o jovem homem passou por ele, Kibandí lhe deu uma última olhada e pensou "veremos bem quem vai emagrecer até se transformar numa estrutura óssea, eu não sou uma dessas pequenas donzelas a quem você conta suas histórias”

de manhãzinha, Amedée começou sua caminhada cotidiana pela savana, só usava um shorts, andou assobiando até a beira do rio onde afundou os pés na água, se estendeu sobre a margem e se pôs a ler os seus livros de mentiras, o meu mestre tinha me dito para ir espiá-lo, para ir ver o que ele estava tramando sozinho, para me assegurar de que esse jovem homem não possuía ele também um duplo que poderia nos causar incômodos quando nos ocupássemos dele, era uma precaução inútil pois, meu querido Baobá, esse homens que vão à Europa, palavra de porco-espinho, se tornam tão limitados que estimam que as histórias de duplos só existem nos romances africanos, e isso os diverte mais do que os incita à reflexão, preferem raciocinar sob a proteção da ciência dos Brancos, e aprenderam raciocínios que os fazem dizer que cada fenômeno tem uma explicação científica, e quando Amêdê me viu sair de um arvoredo perto do rio, palavra de porco-espinho, gritou de raiva "besta suja, saia de perto da minha vista, espécie de bola com espinhos, vou reduzi-lo a massa e comê-lo com pimenta e mandioca", eu aumentei de tamanho, estava à beira da explosão, os olhos exorbitados, fiz os meus espinhos rangerem, dei voltas ao redor de mim, o vi agarrar um pedaço de madeira com a firme intenção de me derrubar, isso me lembrou a atitude de Papai Mationgô na época em que o meu mestre era o seu aprendiz, eu fiz um quarto de volta, procurei qual direção seguir para escapar dessa ameaça de morte, e logo desapareci no arvoredo do qual tinha surgido, Amêdê avançou mais um pouco, eu conhecia esse arvoredo melhor do que ele, me deixei então rolar sobre as folhas mortas e me encontrei embaixo da colina, o pedaço de madeira que ele lançou tombou a alguns centímetros da minha goela, e assim que reencontrei o meu mestre meia hora mais tarde lhe contei como esse tipo tinha nos insultado, como ele tinha tentado nos matar com sua madeira, Kibandí não perdeu a calma, me assegurou "não ligue para isso, não é ele que poderá nos fazer o que quer que seja, eu, eu não estive na Europa, entretanto não sou um inculto, o mayamvumbí nos dispensa de frequentar a escola para saber ler e escrever, ele abre o espírito, capta a inteligência, e esse tipo não pegará de novo o avião pra Europa, sou eu que lhe digo isso, ele é nosso, o seu lugar é sob a terra, para mim ele está morto faz tempo, mas ele não o sabe porque os Brancos não ensinam essas coisas nas suas escolas" 
à meia-noite, enquanto chovia, nós fomos em direção à pequena habitação de Amêdê que se anexava àquela dos seus pais, tínhamos deixado o outro ele mesmo do meu mestre estendido sobre o último tapete tecido por Mamãe Kibandí, o céu rajava de tempos em tempos com relâmpagos ofuscantes, Kibandí se sentou ao pé de uma árvore, me fez sinal para ir lá enquanto ele bebia uma boa dose de mayamvumbí, não esperei uma segunda ordem porque eu estava também furioso com esse pequeno gênio, fui arranhar com raiva a terra sob a porta do seu casebre a fim de abrir passagem, e como caia agora um dilúvio a minha tarefa foi facilitada, o que fez com que rapidinho eu conseguisse cavar um buraco tão grande que mesmo dois porcos-espinho gordos e preguiçosos podiam se introduzir lá sem dificuldade, e uma vez dentro eu vi uma vela acesa, esse imbecil tinha esquecido de apagá-la, dormia de barriga para baixo, então avancei deslizando as patas, cheguei no nível da cama de bambu, não sei porque estava com medo, mas pude dominá-lo, me coloquei sobre duas patas e me agarrei à cama, estava agora entre as pernas abertas de Amêdê, me contraí para escolher o espinho mais firme dentre as dezenas de milhares que queriam todos me ser úteis nesse instante, e pá, lancei a carga que aterrissou bem no meio da nuca do jovem homem, o espinho entrou quase por inteiro nesse cérebro que azucrinava o meu mestre e, consequentemente, me azucrinava também, Amêdê não teve tempo de acordar, foi pego por uma sucessão de espasmos e de soluços enquanto eu me encontrava sobre o seu corpo a fim de retirar o espinho com a ajuda dos meus incisivos, e o removi, lambi o seu sangue até que nenhum traço do meu ato subsistisse, vi o pequeno buraco se fechar como na época em que me ocupei da filha de Papai Lubotô, a jovem e bela Kiminú, dei um salto para voltar ao chão, mas antes de ir embora me aproximei da vela porque queria queimar a cabana, e depois pensei que isso não me serviria para nada, não devia ultrapassar o objetivo da minha missão, Kibandí teria me reprimido, voltei os olhos por curiosidade para o título do último livro que o letrado estava lendo antes de se deitar, Histórias extraordinárias, ele tinha adormecido, envolto no universo dessas histórias, era também um desses livros que lhe permitiam contar mentiras às moças do vilarejo, agora ele iria contá-las aos fantasmas, e nisso, meu querido Baobá, é preciso acreditar porque os fantasmas, é um outro mundo, é um outro universo, não existe ninguém mais incrédulo do que eles, para começar eles não acreditam no fim dos seus corpos físicos, querem mal aos outros por continuarem a viver, querem mal à Terra por continuar a girar, e é por isso que no lugar de irem para o céu essas sombras errantes continuam aqui embaixo com o intuito de reviver, vou dizer que os fantasmas não engolem qualquer coisa

o enterro de Amêdê foi um dos mais emocionantes de Sêkêpembê, o acontecimento contrastava com aquele da lamuriosa Mamãe Kibandí, tinha-se a impressão de que só tinha jovens moças ao redor do finado, estas tinham convocado suas amigas dos vilarejos vizinhos para virem fazer uma homenagem digna desse nome a esse ser excepcional que era o orgulho de Sêkêpembê, da região, quiçá do país, e então quiseram saber o que tinha acontecido ao intelectual, alguns velhos diziam que ele tinha lido demais os livros vindos da Europa, outros exigiam que procedessem com o ritual do cadáver que detecta o seu malfeitor, os pais de Amêdê se opuseram a essa ideia porque, lembraram eles, o seu filho não acreditava nessas coisas, que seria uma ofensa passear com o seu cadáver pelo vilarejo, eles aceitaram essa morte, enterraram o jovem homem com duas caixas de livros, algumas obras estavam ainda embaladas, com os preços da moeda corrente na Europa, e no momento da oração fúnebre, feita dessa vez pelo pároco vindo do vilarejo e não por um dos feiticeiros do vilarejo que se suspeitava serem incapazes de se exprimir em latim, o homem de Deus lembrou como o jovem letrado tinha sabido fazer regredir a ignorância, como ele tinha mostrado que o livro era um espaço de liberdade, de reconquista da natureza humana, ele se exprimiu em latim, leu algumas boas páginas de Histórias extraordinárias, deixou o livro de lado, pegou uma bíblia nova, a colocou sobre o caixão antes de concluir, com uma voz de gralha, "que este livro possa lhe permitir, meu querido Amêdê, aproximar-se das vozes impenetráveis do Senhor e compreender finalmente que a história mais extraordinária, mas realmente a mais extraordinária, é aquela da criação do Homem por Deus, e essa história extraordinária está relatada no Livro santo que eu lhe ofereço para suas leituras no outro mundo, amém" 
o meu mestre era ainda assim um homem tranquilo, sem aparentar, não era bom procurar briga com ele, acho que eu o vi brigando uma ou duas vezes só, e penso no velho Mudionguí, o extrator de vinho de palma, talvez o melhor extrator de vinho de palma de Sêkêpembê, eles se conheciam muito bem, ele e o meu mestre, eu não imaginaria que um dia seria levado a dar fim a esse tosco, digamos que sua vida se limitava ao vinho de palma, ele sabia como retirar o mwenguê, o melhor vinho que uma palmeira podia dar, as mulheres do vilarejo ficavam doidas porque era o vinho menos amargo, ora o ruim do mwenguê é que não nos damos nem mesmo conta da bebedeira, começamos a beber copo após copo, não percebemos que estamos gargalhando como uma hiena, e é só no momento em que nos levantamos que percebemos que não controlamos mais as pernas, então andamos pros lados como um caranguejo, as pessoas se divertem, e dizem "olha aí mais um que consumiu o mwenguê do velho Mudionguí", e o meu mestre tinha adquirido o mau hábito de misturar agora um pouco do mwenguê no seu líquido iniciático a fim de edulcorar, ele não queria mais beber sua bebida sem misturá-la com esse vinho de palma do velho Mudionguí, então todas as manhãs o tosco passava pela cabana de Kibandí para deixar um litro de vinho de palma, ele lembrava a memória de Mamãe Kibandí e dizia como o tempo passava rápido, era na verdade para suscitar a piedade de Kibandí, incitá-lo a lhe dar mais dinheiro, o meu mestre mal o escutava, dava-lhe um papel-moeda amassado, Kibandí estava persuadido que o vinho de palma acrescentava um quê no seu mayamvumbí, ora o velho Mudionguí se tornava caprichoso, ficava zangado por nada, às vezes Kibandí era obrigado a acordá-lo para que ele fosse na savana recolher o vinho de palma, e, tirando proveito da dependência do meu mestre por esse vinho, o velho aumentava o preço do litro segundo os seus humores, era pegar ou largar, "se num tá de acordo, é só ir pegar o mwenguê você mesmo, ou então você paga o preço que eu quero, ponto final", Mudionguí fingia que o mwenguê estava cada vez mais raro, que as palmeiras da região não davam mais esse vinho especial, que o meu mestre devia se contentar com o vinho de palma normal, e um dia esse velho trouxe o mwenguê como de costume, o meu mestre provou, uma dúvida o atravessou, percebeu que não era o verdadeiro mwenguê, que o velho o tinha enganado, não disse nada, mas me chamou uma noite e me disse "olha, amanhã, assim que amanhecer, na hora em que o campo clareia, quero que você siga esse extrator de vinho de palma besta, tem algo de obscuro no seu comportamento, eu o sinto, vá então ver como ele trabalha", e eu segui o tipo desde bem cedo no dia seguinte, o vi desaparecer na floresta, chegar a um lugar onde as palmeiras brotam a perder de vista, o vi chegar no topo de uma palmeira na qual tinha amarrado suas cabaças na véspera, ele as retirou, estavam cheias, desceu, se sentou ao pé dessa árvore, tirou um pacotinho do bolso, o surpreendi despejando açúcar no vinho de palma que acabava de extrair, e como ele não gostava do meu mestre ele até mesmo cuspiu na cabaça vociferando palavras maldosas, contei a Kibandí mais tarde, e então, quando o extrator de vinho de palma despontou diante da cabana de Kibandí para lhe oferecer essa bebida ruim, ele se encontrou face a um homem que lhe cuspia a verdade, eu os escutei brigar, o velho Mudionguí queria a todo preço vender o seu vinho de palma, o meu mestre respondeu que não era o verdadeiro mwenguê, e eles trocaram entre si nomes de pássaros migrantes, o velho Mudionguí insultou o meu mestre, "pobre esqueleto, você está morto faz tempo, está com inveja do meu trabalho porque você não passa de um carpinteiro, é incapaz até mesmo de subir numa mangueira, tipos como você são estragados, maniongí, ngêbês, ngubás ya ko polá”, Kibandí não respondeu a esses insultos em língua bembê $\hat{e}^{160}$ se contentou em dizer ao extrator de vinho de palma "veremos, veremos quem é um maniongí, um ngêbê, um ngubá ya ko polá", o velho Mudionguí disse, antes de partir, "veremos o quê, hein, você não passa de um pobre tipo, não conte mais comigo para beber o mwenguê neste vilarejo, pobre cadáver, sua mãe o espera no cemitério"

eu deixei o meu mestre com o seu outro ele mesmo, os dois estavam dormindo sobre o último tapete tecido por Mamãe Kibandí, o dia começava a levantar, cheguei ao pé da mesma palmeira da última vez quando tinha surpreendido o extrator de vinho de palma misturar açúcar

${ }^{160}$ Uma das línguas bantu faladas na República do Congo. 
na cabaça e cuspir dentro, foi o tempo de eu subir, me esconder no topo dessa árvore, a alguns centímetros dessas cabaças presas bem alto e que transbordavam vinho de palma, as abelhas já tinham instaurado uma festa ao redor, vi chegar o velho Mudionguí, me parecia ansioso porque olhava para a esquerda e para a direita, não compreendia como o meu mestre estava ciente das suas pequenas trapaças, eu o vi arrumar as cordinhas que ia utilizar para chegar até o topo da palmeira, e ele subia agora, subia mais, mas ao chegar na metade do percurso varreu com o olhar o entorno como para se certificar de que ninguém o tinha seguido, e depois, assegurado, continuou a subir, não estava mais tão longe das suas cabaças, e assim que levantou a cabeça, palavra de porco-espinho, cruzou com os meus olhos ao mesmo tempo sombrios e reluzentes, era tarde demais para ele, dois dos meus espinhos já tinham se desprendido e o tinham atingido bem na cara, o velho escorregou, tentou se segurar num galho de flamboaiã que brotava da palmeira, em vão, eu o escutei cair, aterrissar como um saco de batatas lá embaixo, as pernas e os braços afastados, os aldeãos o encontraram nesse lugar um dia depois, os olhos bem abertos, o rosto endurecido, e a população concluiu que ele estava muito velho para extrair vinho de palma, que teria melhor feito de se aposentar há tempos e de iniciar um dos jovens de Sêkêpembê a fim de que este o substituísse 
o problema com Yulá é que ele devia dinheiro ao meu mestre, é sem dúvida um dos episódios que mais me rasga o coração até hoje pois, a bem ver, é o que causou indiretamente o desaparecimento de Kibandí, mas é preciso que eu lhe conte isto com menos precipitação, eu não estava à vontade após ter finalizado essa missão, revia sem parar o rosto da vítima, sua inocência, achava que Kibandí tinha ido um pouco longe dessa vez, teria eu o direito de lhe exprimir os meus sentimentos, hein, um duplo não tem que julgar nem discutir, muito menos se deixar levar pelo remorso a ponto de paralisar o desenrolar das coisas, e para mim esse ato era um dos mais gratuitos que nós tínhamos cometido, Yulá era um pai de família tranquilo, um pequeno camponês sem educação e cuja atividade não ia bem, ele tinha uma mulher que o amava e acabava de ter um filho com ela, um bebê que mal abria os olhos, e depois, um dia, e não sei por que, teve essa história da dívida entre ele e Kibandí, Yulá veio vê-lo para emprestar dinheiro, uma soma entretanto ridícula que ele devia reembolsar na semana seguinte, parece que ele queria comprar medicamentos para o seu filho e jurou que reembolsaria a dívida rapidamente, ele se abaixou, se colocou de joelhos, versou lágrimas pois ninguém tinha querido lhe emprestar a soma derrisória, Kibandí lhe fez esse favor, ele cujas economias diminuíam de ano em ano desde que tinha renunciado à carpintaria, além disso as notas que deu a Yulá estavam tão sujas e amassadas que teriam acreditado que ele as tinha tirado do lixo, e uma semana passou, Kibandí não viu ninguém diante da sua cabana, uma outra semana passou, Yulá não apareceu, tinha desaparecido de circulação, o meu mestre pensou por justa causa que ele fugia, então foi até o seu domicílio dois meses mais tarde, lhe disse para devolver o seu dinheiro senão as coisas iam se complicar entre eles, e como o homem estava bêbado nesse dia ele se pôs a debochar, a insultar Kibandí, a lhe dizer para sair do seu campo de visão, para ir arrastar o seu esqueleto um pouco mais longe, o que não deixou de irritar o meu mestre que lhe jogou a reflexão, "você procura dinheiro para encher a cara e é incapaz de reembolsar suas dívidas", e como Yulá debochava ainda mais, Kibandí acrescentou secamente e em voz alta "quando não temos dinheiro, não fazemos filhos", Yulá se deu ao luxo de resmungar "será que eu lhe devo mesmo dinheiro, eu, hein, você está se enganando de pessoa, saia do meu terreno", sua esposa tomou partido, ordenou por sua vez que o meu mestre fosse embora senão ela ia chamar um sábio do conselho do vilarejo, e assim que o meu mestre chegou em casa, desapontado, eu o vi soliloquiar, proferir injúrias, eu sabia que as coisas iam acabar mal para Yulá, não tinha jamais visto Kibandí em tal estado, nem mesmo quando o jovem pretencioso Amêdê o tinha tratado como doente, e ele me chamou rapidinho, tinha urgência, não podia mais esperar, Yulá ia saber com que fogueira o meu mestre se aquecia, e à meia-noite, depois que Kibandí tinha engolido uma overdose de mayamvumbí, dessa vez sem misturá-lo com o mwenguê para edulcorá-lo, nós estávamos bem preparados, o outro ele mesmo do meu mestre nos acompanhava dessa vez, ainda que eu não visse precisamente qual seria o seu papel, chegamos os três diante da morada do camponês, sua casa estava tão acabada que mesmo um asno podia entrar lá pelos buracos da fachada principal, o meu mestre se sentou ao pé de um flamboaiã, o seu outro ele mesmo estava atrás dele e nos dava as costas como de costume quando estava em movimento, dei a volta na cabana, desemboquei no quarto de dormir, vi Yulá roncando sobre um tapete enquanto sua mulher estava na cama, do outro lado do cômodo, isso se passava assim sem dúvida toda vez que o esposo estava bêbado, e eu atravessei o quarto, me orientei em direção ao quarto do filho, assim que me aproximei do bebê tive um aperto no coração, quis dar meia-volta, o outro ele mesmo de Kibandí estava atrás de mim, me perguntei por que o meu mestre tinha decidido atacar a criança ao invés de atacar o homem que lhe devia dinheiro, ou a rigor sua esposa que tinha ousado tomar partido enquanto discutiam, os meus espinhos se tornaram pesados e preguiçosos, eu pensava que não poderia projetar nem um, nunca tinha atacado uma criança até aquele dia, precisava encontrar um motivo a fim de aumentar a minha determinação e recolocar energia nas minhas armas, mas qual motivo encontrar, eu não o via, e depois, de repente, eu pensei que o meu mestre tinha ainda assim razão de lembrar a esse tipo que quando não temos dinheiro não fazemos filhos, me lembrei também que o velho porco-espinho que nos governava professava outrora que os homens eram maus, incluindo os seus filhos, por que "os filhotes do tigre não nascem sem as suas garras", então era preciso procurar uma imperfeição nesse Yulá, era preciso encontrar um defeito imperdoável nele, e eu repeti a mim mesmo que esse tipo era um bebum, ademais o seu pobre filho ia ter uma existência de merda junto a esse camponês sem 
educação, murmurei a mim mesmo esses últimos argumentos como para varrer a onda de remorsos, como para afastar a piedade que adormecia os meus espinhos, estes reencontraram de repente sua energia, eu os sentia agora barulhentos, a raiva do meu mestre tinha se tornado a minha, era como se Yulá me devesse dinheiro, e não pude perceber que o ser diante de mim era apenas um inocente, eu me dizia ao contrário que nossa ação ia antes libertá-lo, aliviá-lo, Yulá não merecia ser pai, ele que era alcoólatra, ele que não honrava os seus compromissos, ele que devia talvez dinheiro a toda a população, e foi nesse instante de reflexão que me contrai, um espinho firme se desprendeu das minhas costas para atingir a pobre criança, o outro ele mesmo do meu mestre tinha desaparecido do cômodo, sem dúvida estava ele lá para melhor me incitar a ter coragem de agir, saí rápido do lugar a fim de evitar a tristeza, não devia sobretudo olhar um pequeno inocente desaparecer deste mundo devido à imbecilidade e ao descuido do seu pai, não queria ver essa cena, e entretanto eu não estava tranquilo, tinha vergonha da minha imagem assim que ela se refletia no rio, fui assistir ao enterro, um pouco com a esperança de me fazer perdoar, escutei toda essa gente entoar cantos fúnebres, e versei lágrimas

nos dias seguintes a esse acontecimento, a imagem do bebê de Yulá aparecia para mim, me assombrava, comecei a temer a minha própria silhueta em pleno dia, a me dizer que o fantasma desse bebê me esperava no primeiro arbusto, talvez tudo isso já pesasse na minha consciência, e assim que me retirei na savana fiz o balanço, analisei os outros fatos, os menos graves, os mais ou menos graves, os graves, e sobretudo os bem graves como a morte desse menino, e os rostos das nossas vítimas se mostravam para mim, nós já estávamos na nonagésima nona missão, mas nenhuma desconfiança recaia sobre nós nesse momento, o meu mestre se safava sempre graças à noz de palma que ele enfiava no reto, e eu não entendia por que, de todas as vítimas, só o bebê de Yulá me impedia de sonhar com outra coisa, tudo se passava como se ele nos espiasse, nos esperasse na esquina, e afinal, pensava eu, era apenas um humano minúsculo sem força e sem poder, eu me lembrava também que o velho porco-espinho que nos governava nos alertava sobre nossos menores inimigos que eram os que mais devíamos temer, então acontecia de eu pensar que esse bebê me enviava uma mensagem, me empurrava à revolta e que bastava colocar um fim nos meus dias para acabar com o fluxo das nossas missões, ou me rebelar contra o meu mestre enfrentando-o, ou desaparecer sem deixar traços, mas uma força me retinha ainda que eu tivesse o pressentimento de que a centésima missão nos seria fatal, nos custaria a vida certamente, talvez fosse apenas uma angústia, e estava persuadido que, do seu lado, Kibandí não contabilizava nada, se deixava levar pelas vertigens, pela bebedeira do mayamvumbí 
como as vítimas se acumulavam, eu não sentia mais prazer em obedecer ao meu mestre, ele era obrigado a gritar várias vezes, grudar o seu outro ele mesmo no meu traseiro, me ameaçar de morte, eu sabia entretanto que ele não podia colocar em execução essa última intimidação, ele assinaria nosso desaparecimento, e então, meu querido Baobá, nossa empreitada noturna se fragilizava

os olhares da população se voltavam ao meu mestre que parecia agir apenas por rotina, nós tínhamos em seguida tido dificuldades para finalizar a centésima missão, não contávamos mais os fracassos, os meus espinhos se tornavam menos eficazes, erravam o alvo, como com essa mulher que se chamava Ma Mporí, eu a tinha acertado na panturrilha, os meus espinhos não provocaram nadinha de nada, isso poderia já ter chamado a atenção de Kibandí, ora o meu mestre desejava que eu recomeçasse a missão, é impensável e até mesmo intrépido atacar duas vezes a mesma pessoa, eu sei que essa mulher tinha também alguma coisa, essa mulher não era um ser ordinário, ela me tinha feito compreender ao me perguntar várias vezes quem tinha me enviado, quem era o meu mestre, só um iniciado perguntaria esse tipo de questão, e quando penso na velha Mporí digo a mim mesmo mais uma vez que poderíamos ter redobrado a vigilância, o meu mestre não estaria hoje sob a terra apodrecendo, mas essa velha Mporí, vou lhe contar, era uma outra história, estou certo de que ela tinha comido algumas pessoas deste vilarejo, e aliás por que eu falo dela no passado se ela está ainda viva, hein, ela não tem mais dentes, deixa a porta aberta a noite inteira, mostra sua nudez em sinal de maldição quando os jovens lhe faltam ao respeito, e esses jovens saem correndo porque ver tal espetáculo os amaldiçoa eternamente, ela fica em pé sobre as pernas raquíticas com uma pele de lagarto velho, não existia nenhum antecedente entre ela e o meu mestre, entretanto Kibandí imaginava que ela sabia o que nós fazíamos à noite, ela nos incomodava então, ela era um perigo, era preciso fazêla desaparecer, era mais fácil dizer do que fazer mesmo sua porta estando aberta no dia em que eu devia executar a missão, foi mês passado, eu estava sozinho, nem mesmo acompanhado pelo outro ele mesmo de Kibandí, a menos que ele tenha ido se esconder em algum canto sem meu conhecimento, Ma Mporí se encontrava no seu casebre, e quando eu enfim entrei lá teve como uma noite que me cegava, eu não via nada, mal adivinhava a silhueta da velha num canto, os meus espinhos não se mexiam mais, eu precisava agir entretanto, executar a missão, foi então que a escutei murmurar "avance então besta velha, você vai saber quem é Ma Mporí, vou lhe mostrar a minha nudez", ela mesma me via, e eu, eu não podia distingui-la, e ela acrescentou "os trecos que você faz neste vilarejo junto àquele que o enviou aqui, num é a mim não que os fará, você se deu mal, pobre imbecil", eu comecei a ter medo, quis dar meia-volta enquanto atrás de mim a porta parecia ter se fechado, tinha como uma parede, evidentemente era uma ilusão, "quem é então o seu mestre, hein, quem o enviou aqui, é esse carpinteiro Kibandí, num é, hein, é ele mesmo, hein", me gritava ela, e como eu não respondia escutei a cama ranger, Ma Mporí se colocou de pé, essa velha cansada transbordava agora de energia, "diga você mesmo quem é o seu mestre, vocês não comeram gente suficiente desse jeito no vilarejo, hein, o bebê de Yulá, foi também vocês, hein”, e então, palavra de porco-espinho, era preciso me apressar pois ela avançava na minha direção com determinação, ela tinha algo nas mãos, uma machete, pensava eu sem entretanto ter certeza disso, pude armar um espinho rapidamente, o projetei na sua direção, a escutei gritar "besta suja, o que é que você fez no meu tornozelo, hein, espere um pouco que o pego", procurei uma saída nessa opacidade que cegava, segui direto para a porta, me encontrei do lado de fora, a velha saiu do seu casebre, levada por suas pernas magras de repente ágeis, ficou parada em pé falando diante da entrada da sua cabana, "vocês espíritos maus deste vilarejo, eu os vejo de noite, vocês feiticeiros e maldosos deste vilarejo, quando eu deixo a minha porta aberta como agora, é para lhes pregar uma peça, tentem então voltar aqui, e verão de muito perto a minha nudez", eu já estava longe, era meu maior medo, meu coração batia forte, se eu tivesse tido coragem teria dito ao meu mestre que tínhamos atingido o limite da nossa atividade, que não podíamos sobretudo ultrapassar a linha vermelha, infelizmente eu nada disse, e além de tudo foi Kibandí quem me criticou, ele foi muito cruel a meu respeito, se esqueceu da minha devoção, dos serviços que eu tinha feito para ele até aquele dia, me tratou de bom para nada, me ameaçou de morte uma vez mais, foi nesse dia que eu entendi sua relação 
com o seu outro ele mesmo, de fato o meu mestre me apontou com o dedo o outro ele mesmo dormindo sobre o último tapete tecido por Mamãe Kibandí antes de concluir "você vê bem esse tipo dormindo, hein, nesses últimos tempos ele tem tido cada vez mais fome, e não é o momento de causar problemas como você o fez, ele tem que comer, esse tipo, senão nós pagaremos caro, você ignora que cada vez que ele tem fome, sou eu quem suporta tudo", e ele me lembrou que eu devia recuperar o tempo perdido, que eu devia atacar dessa vez a família Mundjulá, um casal chegado a Sêkêpembê há pouco com os seus dois filhos, uns gêmeos que, dizia ele, lhe faltavam ao respeito, o meu mestre estava então longe de saber que ele acabava de assinar a sua sentença de morte ao me confiar essa missão que seria o centésimo sucesso, perdão, o centésimo primeiro já que nós daríamos dois golpes com uma só pedra 
palavra de porco-espinho, como o tempo passa rápido, estou rouco, a noite já caiu sobre Sêkêpembê, e eu aqui chorando sem compreender por que, a solidão me pesa desta vez, me sinto culpado de não ter nada feito para salvar o meu mestre, era eu capaz disso face a esses dois meninos que não pouparam esforços algumas semanas antes da sua morte, hein, eu não sei de nada, queria primeiro salvar a minha própria pele ainda que estivesse persuadido que a morte de Kibandí acarretaria a minha, e, nessas condições, os homens têm razão de afirmar que um covarde vivo vale mais que um herói morto, digamos que eu não estou atravessado pela tristeza que me causa a ausência de Kibandí, também não estou incomodado com a sorte que tenho de viver até hoje, de tê-lo como meu confidente, tenho vergonha do que lhe contei desde esta manhã, não gostaria que me julgasse sem levar em conta o fato de que eu não passava de um subalterno, uma sombra na vida de Kibandí, jamais aprendi a desobedecer, tudo se passava como se eu estivesse tomado pela mesma raiva, pela mesma frustração, pelo mesmo rancor, pelo mesmo ciúme que o meu mestre, e eu não gosto do meu estado de espírito atual porque os rostos das nossas vítimas não param de me assombrar, essas pessoas desaparecidas estão mais ou menos lá diante de mim, me rodeiam, espiam, mostram o dedo, posso ler nas suas caras os motivos que nos conduziram a pôr um fim em seus dias, eu poderia consagrar um ano inteiro para lhe falar disso, nós tínhamos comido por exemplo o jovem Abebá porque ele tinha ridicularizado a magreza do meu mestre a quem ele tinha surpreendido seminu à beira do rio, era imperdoável, acredite em mim, nós tínhamos comido Asalaká porque ele tinha profanado a tumba de Mamãe Kibandí depois de ter tratado o meu mestre de feiticeiro, era desrespeitoso, os mortos têm direito de repousar, nós tínhamos comido Ikonongô porque ele tinha ousado defender a atitude do profanador da tumba de Mamãe Kibandí, então ele também era solidário aos atos desse profanador, nós tínhamos comido Lumuamú porque ela tinha rejeitado as investidas do meu mestre em público no bistrô Le Marigot, além disso era ela quem tinha provocado Kibandí, e depois ela fingiu que era o meu mestre quem tinha ido longe demais, que para ela era apenas um jogo, também disse que Kibandí deveria se olhar no espelho antes de falar com uma mulher como ela, você vê que tais discussões eram intoleráveis, nós tínhamos comido o velho Mabêlê porque ele disseminava mentiras a respeito do meu mestre, ele lhe atribuía o roubo de um galo vermelho do chefe do vilarejo, o que não era nem mesmo verdade já que são os meninos deste vilarejo que fazem esse tipo de roubo, nós tínhamos comido Mufundirí porque ele era desses que queriam que um feiticeiro viesse purificar o vilarejo, livrálo de todos os detentores de duplos nocivos, ele achava que era quem, hein, sobretudo porque o meu mestre não queria terminar como o seu pai, ele se lembrava do feiticeiro Tembê-Essuká que tinha estado na origem da morte de Papai Kibandí, nós tínhamos comido Luvunú porque ele confessava ter visto um animal bizarro que se parecia com um porco-espinho atrás da cabana do meu mestre, ele dizia coisas do tipo "por um lado era como um porco-espinho, lhe digo, e por outro, é bizarro, nem era como um porco-espinho, quero dizer, era um animal estranho, me olhou como um homem poderia olhar um outro homem, e me mostrou o seu traseiro antes de desaparecer no ateliê do carpinteiro, juro que não sonhei, acredite em mim", esse tipo tinha razão mas tinha cometido o erro de ir relatar a cena ao chefe do vilarejo que veio falar disso com Kibandí mostrando-lhe o dedo, nós tínhamos comido Ekondá Sakadê porque ele tinha visto o meu mestre falar comigo num arbusto perto da tumba de Mamãe Kibandí, ele também tinha ido relatar a cena ao chefe do vilarejo, nós tínhamos comido o sábio e velho Otchombê porque ele tinha se oposto à candidatura de Kibandí ao conselho do vilarejo com o motivo de que o meu mestre era e continuaria sendo um estrangeiro, o que o tinha ofendido, ele que se esgotava para mostrar ao vilarejo que era um habitante ordinário, nós tínhamos comido o comerciante Komayayô Batobatangá porque ele tinha se recusado a nos vender fiado um lampião e duas latas de sardinha a óleo fabricadas no Marrocos, era uma injustiça da sua parte pois todo o vilarejo comprava fiado com ele, nós tínhamos comido a velha Dikamoná porque ela fazia uns vai e vens suspeitos todas as noites diante da cabana do meu mestre, essa mulher queria na verdade surpreender os dois, o meu mestre e eu, desde que corriam boatos de que este tinha alguma coisa, e, na realidade, palavra de porco-espinho, nós tínhamos começado a comer as pessoas por um sim ou por um não, porque era preciso alimentar o outro ele mesmo do meu mestre, e quando essa criatura sem boca, sem orelhas e sem nariz estava satisfeita, ela não saia mais do último tapete tecido por Mamãe Kibandí, se arranhava, peidava, jamais um ser normal 
tinha tido tanta fome quanto ele, e, o olhando estendido sobre o tapete, eu podia adivinhar que tinha fome, porque ele se virava de repente, se remexia durante uma meia hora antes de permanecer imóvel tal qual um cadáver

se algumas das nossas vítimas não se demoram mais na minha memória, é porque, meu querido Baobá, as missões que eu realizava então remontavam ao meu longo período de aprendizagem, eu as considero tão idênticas que talvez as tenha misturado ao longo da narração que lhe fiz dos atos que são aos meus olhos os mais importantes da minha carreira de duplo a fim de chegar à missão mais que perigosa de sexta-feira passada

eu vejo essa família recém-chegada a Sêkêpembê, vejo os dois meninos que correm, que gritam, que estão por todo canto ao mesmo tempo, já via essas cenas como uma advertência, quis alertar o meu mestre, ele tinha uma ideia, já tinha um plano bem estabelecido, não podia aceitar a impertinência desses pequenos, e ele murmurava palavras maldosas a respeito deles, procurava na verdade um álibi, o motivo que iria levá-lo a se desfazer disso de uma vez por todas, mas as coisas se passaram de outra maneira 
o meu mestre estava possuído pela sede do mayamvumbí e pelo apetite inextinguível do seu outro ele mesmo, assim tinha negligenciado algumas proibições elementares que observam os detentores de duplos nocivos, por exemplo não atacar sobretudo gêmeos, ele agia agora com uma leveza que me deixava boquiaberto, a prudência estava mais do meu lado, ele estava convencido de que desafiar essas proibições o levaria ao ápice, como se corresse para superar o recorde do seu pai, é por isso que ele não ficava mais tranquilo desde que a família Mundjulá tinha se instalado em Sêkêpembê, e aliás, na época da chegada dos Mundjulá, o pai de família não escondia o seu orgulho, arrastava os filhos pela rua como para mostrar aos aldeãos a sorte que ele tinha que ser pai de gêmeos, tirava sarro então das queixas de alguns habitantes que atribuíam aos dois meninos os estragos de todo tipo nos seus terrenos, Kibandí mal conhecia essa família, o chefe do vilarejo tinha feito o favor de apresentar os novos habitantes à população, ele tinha margeado a estrada principal, parado diante de cada cabana e repetido "Papai Mundjulá é escultor, sua mulher é faxineira e cuida dos gêmeos, crianças encantadoras", eles moravam do outro lado do vilarejo, se integravam ao resto da população dia após dia a ponto de termos a impressão de que eles tinham sempre vivido aqui

conheci essas duas crianças terríveis em circunstâncias mais que infelizes, são gêmeos que não possuem na realidade nenhum sinal que permitiria ao observador mais meticuloso separar um do outro, o seu pai e a sua mãe os chamavam indiferentemente de Koty ou Kotê já que basta chamar um dos dois para que se virem simultaneamente, mas no fundo Papai e Mamãe Mundjulá sempre sentiram prazer em semear a confusão no espírito dos aldeãos enquanto eles têm secretamente um truquezinho deles para distinguir um do outro, na verdade Papai e Mamãe Mundjulá tinham decidido circuncidar apenas um dos dois meninos, conta-se no vilarejo que é o mais velho que é circuncidado enquanto o mais novo não o é, e, toda vez, quando a confusão chega para eles mesmos, Papai e Mamãe Mundjulá desvestem a sua progenitura para saber qual dos dois veio ao mundo primeiro, lhe asseguro que são dois toquinhos de no máximo dez ou onze anos, dois seres inseparáveis que piscam, se arranham, tossem, peidam, se machucam, choram e ficam doentes ao mesmo tempo, duas entidades idênticas que dormem um nos braços do outro até de manhãzinha, se sentam da mesma maneira, as pernas cruzadas, e, como se os seus pais desejassem confundir ainda mais, os vestiam com roupas idênticas, calças com suspensórios azuis, camisas beges de algodão, eles têm cabeças tão grandes quanto um tijolo de terracota, Papai e Mamãe Mundjulá raspam os seus crâneos, quer dizer que eles não são bonitos com os seus olhos esbugalhados, mal se misturam com os outros meninos, correm por todo o vilarejo, adoram brincar perto do cemitério, numa vasta plantação de lantanas onde eles mudam as cruzes dos túmulos, as invertem, brincam de esconde-esconde, perseguem sem pausa as borboletas, espantam os corvos, deixam a vida dura aos pardais com a ajuda dos seus temíveis estilingues, não se pode controlá-los, estão sempre lá onde não os esperam, então a primeira vez que eu tinha cruzado com Koty e Kotê os meus espinhos tinham se eriçado em sinal de alerta, esses gêmeos quiseram me fazer de brinquedo deles assim que me notaram me agitando na plantação de lantanas, na verdade eu estava voltando do meu esconderijo e repousava sobre o túmulo de Mamãe Kibandí, me preparava para ir em seguida vagar atrás do antigo ateliê do meu mestre, e talvez ler um pouco sem me afastar muito da cabana de Kibandí, apenas no caso dele precisar de mim, e os dois meninos me escutaram remexendo a folhagem, se viraram, um dos dois me apontou o dedo "um porco-espinho, um porco-espinho, vamos pegá-lo", o outro menino começou a armar o seu estilingue, e eu, palavra de porco-espinho, dei meia-volta catastroficamente enquanto os seus projéteis vinham cair a alguns metros de mim, me perguntei de onde tinham saído esses dois atrevidos que suportavam cabeças tão retangulares, num dado momento pensei que fossem pequenos fantasmas a quem os pais, do fundo dos seus túmulos, tinham dado permissão para ir brincar lá fora e voltar antes do pôr do sol, mas esses dois malandros conseguiram me perseguir, os escutei afastando as lantanas, soltando gritos de alegria, rindo como hienas, um deles ordenou ao outro para ir pelo lado direito enquanto ele mesmo continuaria pelo lado esquerdo a fim de me surpreender algumas centenas de metros à frente, ora eles ignoravam que eu compreendia a linguagem dos humanos, então acabei com o plano deles, virei uma bolinha imediatamente, rolei a uma 
velocidade vertiginosa, aterrissei sobre uma cama de samambaias mortas, vi diante de mim um entrelaçamento de espinhos, segui sem me virar para enfim cair sobre uma clareira que dava sobre o rio, e então, sem refletir, mergulhei na água não muito profunda nesse ponto, respirava como um desvairado, rapidamente ganhei a outra margem, sacudi os meus espinhos, mas eu tremia mais de medo do que de frio, o vilarejo estava doravante à vista, não escutava mais barulho atrás de mim, cheguei à conclusão de que os meninos tinham dado meia-volta, eu não estava certo de que eles viviam em Sêkêpembê, mas vários dias após esse episódio, quando eu os vi atravessando a rua principal com o pai, reconheci suas cabeças retangulares, suas roupas idênticas

terça-feira passada, no começo da tarde, Koty e Kotê tinham mais uma vez escapado do controle dos pais, passaram diante da cabana do meu mestre que estava sentado diante da porta e que devorava um livro esotérico, os gêmeos não tinham parado de aparecer assim há algum tempo, ficavam em frente a seu domicílio, bem no lugar onde o meu mestre tinha visto no passado esse estranho rebanho de carneiros no dia da morte de Mamãe Kibandí, e os dois pequenos pareciam espiá-lo, imitar o lamento de um carneiro idoso que é degolado, debochavam e depois desapareciam, esse comportamento acabava a longo prazo irritando o meu mestre que estava certo de que as duas crianças eram enviadas por seus pais para importuná-lo, e quando ele tentava se aproximar a fim de falar com eles, de lhes dizer que lhe deviam respeito, os meninos fugiam, voltavam no dia seguinte para se colocar no mesmo lugar, imitar o carneiro idoso, eu vi o meu mestre perder a calma, se colocar mil e uma questões, essas crianças queriam lhe indicar alguma coisa, elas sabiam alguma coisa que nos concernia, e então nessa terça à tarde Koty e Kotê se plantaram como de costume em frente ao domicílio do meu mestre, este esboçou um sorriso, os diabinhos não o retribuíram, "o que é que vocês querem de mim, hein", acabou por dizer Kibandí, um dos dois pequenos Mundjulá respondeu "o senhor é um malvado, é por isso que não gosta das crianças", e o meu mestre, desconsertado, respondeu "pobres diabinhos, vocês não têm educação, por que me tratam de malvado, hein, será que vocês sabem que posso contar ao seu pai", e o outro menino acrescentou "você é um malvado porque você come as crianças, nós sabemos que você comeu um bebê, ele nos disse ontem quando a gente brincava no cemitério, e aliás ele vai nos dizer de novo esta noite", o meu mestre fechou o seu livro com um gesto nervoso, não pôde conter sua raiva, se levantou gritando palavrões "bando de vermes, pássaros agourentos, pequenos sanguessugas, vou lhes ensinar como respeitar os adultos", ele quis correr atrás dos gêmeos quando um deles lançou "e mesmo o bebê que você comeu, ele nos disse para lhe dizer que ele o observa, que ele virá vê-lo, é por sua causa que ele não cresce mais", e os dois moleques fugiram, Kibandí os viu desaparecer no horizonte, disse a si mesmo então que devia custe o que custar encontrar os pais desses pequenos seres 
o meu mestre foi até a família Mundjulá por volta do fim da tarde dessa terça-feira, o pai esculpia uma máscara com traços hediondos, a mãe preparava um prato de folhas de mandioca com bananas-da-terra, o casal ficou surpreso ao vê-lo chegar pois jamais o tinham visto atravessar o umbral desse terreno, o pai logo interrompeu o seu trabalho, se apressou a indicar uma cadeira cheia de trepadeiras ao visitante, a mãe o saudou de longe, perguntaram a Kibandí se ele queria beber vinho de palma, ele disse não ainda que fosse mwenguê, a mãe trouxe-lhe água fresca numa cabaça antes de se retirar e deixar os dois homens conversarem, o meu mestre olhava para o interior da cabana na esperança de ver os dois meninos, eles não estavam lá, deviam estar ainda correndo pelo vilarejo, talvez perto do cemitério, na plantação de lantanas, Kibandí revelou o motivo da sua visita após algumas generalidades sobre a construção dos Mundjulá que, segundo o meu mestre, estava mal erguida, depois foi direto ao ponto, "os seus gêmeos vêm me incomodar há mais de duas semanas, eles vieram me provocar também hoje no começo da tarde", Papai Mundjulá observou um breve silêncio antes de responder "eu sei, eu sei, são duas pestinhas, vou falar com eles, eles estão sempre indo pra direita e pra esquerda, o senhor não é o único a se queixar, mas sabe, na idade deles, eles não medem as consequências dos seus atos", e então o meu mestre explicou como os dois meninos o tinham chamado de malvado, como eles não lhe diziam nem mesmo bom dia, como eles tinham dito coisas que ele preferia não repetir por respeito aos seus pais, Papai Mundjulá fitou Kibandí, podia-se ler a comiseração no olhar desse pai de família, sem dúvida ele pensava que esses meninos tinham debochado da magreza do meu mestre, que essa magreza lhes tinha parecido tão estranha que não esconderam o que pensavam dentro deles mesmos, e, no mesmo instante, enquanto Papai Mundjulá perguntava a Kibandí o que os seus filhos tinham realmente dito contra ele, Koty e Kotê chegaram, as roupas cobertas de poeira, apenas deram um olhar apressado para o pai e seu visitante, na verdade foram correndo para a mãe gritando que estavam com fome, a marmita ainda estava no forno, e a mamãe disse "isso vai lhes ensinar a correr pelo vilarejo o dia todo, a comida não está pronta”, Papai Mundjulá os chamou com um ar autoritário "Koty, Kotê, venham apresentar suas desculpas ao Titio Kibandí, agora mesmo, ele não é malvado, eu não gosto que faltem com o respeito às pessoas grandes", por bem ou por mal, os dois meninos vieram, e o pai disse ao primeiro "dê a mão a ele, é seu tio, todos os adultos deste vilarejo são seus tios, você deve respeitar Titio Kibandí como você me respeita, ele tem o direito de lhe dar uma palmada na bunda se você lhe faltar com o respeito na próxima vez", Kibandí estendeu a mão seca e esquelética que Koty, ou talvez Kotê, observou com desconfiança e repulsa antes de estender enfim a sua, o menino olhou Kibandí direto nos olhos, teve como um silêncio, a criança tinha o olhar duro, e, de repente, o seu rosto se metamorfoseou, se tornando mais liso, mais jovem, a cabeça grande e careca se cobriu de cabelos macios, se tornou mais redonda, o meu mestre sentiu como uma descarga elétrica atravessar o seu corpo, ele via o rosto do bebê Yulá no lugar do do gêmeo que lhe estendia a mão, "não olhe para os adultos desse jeito", disse Papai Mundjulá, e, ao apertar em seguida a mão do outro gêmeo, o meu mestre teve a mesma visão, sempre esse rosto de bebê que nós tínhamos comido, abaixou rápido os olhos, Papai Mundjulá não viu nada dessa cena, os meninos apresentaram suas desculpas ao meu mestre, não sem murmurar com uma ponta de ironia "até bem breve Titio Kibandí, passaremos para vê-lo sexta-feira", e, sempre com a mesma ponta de ironia, disseram em coro "passe uma boa noite, Titio Kibandí", foi então que Papai Mundjulá soltou, satisfeito e orgulhoso da conduta dos seus gêmeos, "o senhor verá, são dois meninos extraordinários, são tão apegados que assim que o acontecido passar entre vocês, eles irão brincar todos os dias no seu pátio", mas Kibandí estava longe nos seus pensamentos, o rosto do bebê Yulá tinha ficado gravado em seu espírito, ele não ousava mais olhar para os gêmeos, sabia que devia agora se ocupar desses dois seres que, aparentemente, eram os únicos a saber tudo sobre nossas atividades noturnas, e foi assim que ele recusou o jantar que lhe propôs a família Mundjulá, disse como pretexto que tinha um trabalho urgente que devia terminar antes do cair da noite e se despediu sem se virar, falava sozinho andando, quase caiu ao trombar contra uma pedra, se pôs a beber mayamvumbí a noite inteira, eu o escutei rir de maneira incomum e pronunciar várias vezes o nome desse bebê que nós tínhamos comido, esse riso era só fachada, descobri pela primeira vez que o meu mestre podia também ficar apavorado a ponto de perder a calma 
depois dessa terça-feira na qual o meu mestre tinha ido se queixar a Papai Mundjulá, sua vida estava doravante pontuada por pequenas desgraças, e já na mesma noite, por volta da meia-noite, ele escutou um bebê chorar atrás do seu ateliê, escutou também risos de meninos, corridas desenfreadas, mergulhos no rio, escutou o barulho das bestas voadoras que vinham aterrissar na sua cama, não pôde fechar o olho, ficou à espreita até o amanhecer, foi só na manhã seguinte que decidiu que a comédia tinha durado mais que o necessário, e pela primeira vez, para a minha grande surpresa, ele me chamou em pleno dia, compreendi que ele tinha perdido a cabeça, jamais um iniciado teria chamado o seu duplo nocivo em pleno dia para lhe detalhar uma missão, mas eu não podia lhe desobedecer, saí então do meu lugar de descanso, eu não sentia mais o mesmo ardor que governava as minhas patas na época em que as coisas se passavam como nós as tínhamos previsto, agora se tratava de uma urgência, até então nós tínhamos atacado pessoas vivas, não tínhamos confrontado as sombras da noite, jamais um ser que tínhamos comido tinha voltado para nos pedir as contas, e quando cheguei diante da casa de Kibandí empurrei a porta com uma pata, fiquei plantado na entrada, a surpresa era grande, vi um homem desamparado, um homem que tinha passado a noite inteira bebendo mayamvumbí, os traços enrijecidos como se ele não tivesse dormido desde duas ou três luas, eu lia o medo que congelava o seu olhar, ele me disse para entrar, me olhou, murmurou palavras ininteligíveis, eu, eu pensava então que nós iríamos abandonar o vilarejo de Sêkêpembê, que iríamos seguir o destino da sua família, empreender o perpétuo êxodo, achar um outro território, ora ele falou antes dos gêmeos, era para ele uma obsessão, disse que esses dois meninos eram mais poderosos do que ele imaginava, que devíamos nos ocupar deles o mais tardar na sexta-feira, me repetiu que eu devia ficar perto dele, que não queria sobretudo que eu voltasse para a floresta antes dessa missão à qual ele prezava mais do que as 99 precedentes, e então passei o dia num canto escuro da sua cabana enquanto ele continuava inerte sobre o seu tapete, os gêmeos não voltaram a perturbar o meu mestre na minha presença naquela noite, não passava na verdade de uma falsa calmaria já que na sexta-feira, por volta das dez horas da noite, quando estávamos prontos para ir para os arredores do terreno dos Mundjulá, o meu mestre e eu fomos alarmados pelo barulho dos pássaros noturnos que se agitavam sobre o teto da cabana, um vento violento desmantelou a porta da habitação, o antigo ateliê do meu mestre voou com estrondo, fomos ofuscados por uma claridade, como se o dia se levantasse no meio da noite, e no pátio nós vimos o bebê Yulá que tínhamos entretanto comido, ele parecia em plena forma, nos mostrava o dedo, estava acompanhado por suas duas espécies de guarda-costas, os gêmeos Koty e Kotê, estes tinham capturado o outro ele mesmo do meu mestre, e era penoso assistir a essa cena, era como se o outro ele mesmo de Kibandí não tivesse mais nem mesmo o poder que atribuímos aos espantalhos das plantações de milho, ele estava passivo, parecia um fantoche, um polichinelo, uma marionete cheia de algodão, de panos, de esponjas, e os dois atrevidos o balançavam segundo os seus caprichos, o rolavam na poeira, tentavam colocá-lo em pé, as pernas do outro ele mesmo do meu mestre cediam, a cabeça recaia sobre o peito enquanto os braços lhe chegavam até os joelhos, os meninos riam, Kibandí me mandou rápido uma ordem, "lance, lance então todos os seus espinhos, lance-os, merda", infelizmente os meus espinhos não se moviam mais, estava petrificado por essa visão, e então os gêmeos largaram no chão o outro ele mesmo do meu mestre, se aproximaram de nós, alcançaram a altura do bebê Yulá, eu os encontrei transformados, metamorfoseados como se não fossem mais os mesmos toquinhos que tinham me perseguido no cemitério, Kibandí recuou, nós rapidamente nos protegemos na cabana, os escutamos chegar como um rebanho de mil bois, os seus passos remexiam a terra, sacudiam a fachada da cabana, eles entraram, eu me encolhi num canto, Kibandí tinha corrido para o quarto, o vi surgir com uma zagaia na mão, os gêmeos e o bebê se torceram de rir ao ver a sua arma, o meu mestre se posicionou, tentou projetar a zagaia, as suas mãos estavam pesadas, tão pesadas que a arma caiu aos seus pés, então um dos gêmeos saltou sobre ele, o agarrou pelo pé esquerdo, o outro gêmeo segurou o pé direito, puxaram cada um do seu lado enquanto o bebê Yulá ria diante da entrada, e eu vi Kibandí desmoronar no chão como uma velha árvore abatida com um só golpe, não sei o que essa pequenas fúrias lhe fizeram na sequência já que eu tinha fechado os olhos tomado pelo medo, escutei como uma descarga, um tiro, e entretanto não existia arma de fogo na cabana, e entretanto os gêmeos não tinham nada entre as mãos, eu tremia como um novato, a claridade ofuscante que tinha aparecido com a chegada desses seres 
desapareceu como por encantamento, a noite caiu sob nós por um gesto da mão direita elevada ao céu pelo bebê Yulá, e, de um outro gesto da mão esquerda, ele fez reaparecer essa claridade ofuscante como se ele pudesse doravante governar os fenômenos da natureza, eu via do meu esconderijo as suas pequenas pernas enlameadas, e, como ele pousava agora o seu olhar de brasa na minha direção, entendi que vinha me pegar, que não ia me poupar, me fuzilava cada vez mais com o olhar, com ar de quem diz que eu estava acabado como o meu mestre que jazia perto da porta, então comecei a me agitar mais e mais, e depois, surpreendentemente, o bebê desviou o olhar, pensei que ele não queria me atacar ele mesmo, que ia dar a ordem aos gêmeos para que me reservassem o mesmo castigo que ao meu mestre, pois bem, não, no máximo, quando olhou de novo para mim, me fez um sinal com a cabeça, me pedia para fugir, eu não acreditava nisso, não precisou que me pedisse duas vezes, saí correndo discretamente, passei pelo quarto do meu mestre enquanto o escutava soltar um longo soluço, o último suspiro, era o seu último minuto nessa terra, e eu, eu corria sempre na noite como um fugitivo

já é tardo meu querido Baobá, a lua acabou de desaparecer, sinto as minhas pálpebras que pesam, os meus membros que não aguentam mais, a vista que embaça, não sei se são os braços da morte que se estendem a mim, não posso mais resistir muito tempo, não posso mais aguentar, estou fraquejando, tenho sono, sim, tenho sono 
o dia acaba de nascer, estou surpreso de constatar a vida ao redor, os pássaros que voltam para pousar sobre os troncos das árvores, o rio que flui com mais turbulência, uma agitação que aliás me tranquiliza, então é também uma pequena vitória, devo entendê-la tal qual, quase não vi o passar do tempo desde ontem, me contentei em falar com você até que as minhas pálpebras estivessem pesadas, você afinal não me interrompeu um só instante, ainda não sei entretanto o que pensa dessa história, bom, de qualquer maneira, me sinto mais que aliviado porque pude me entregar, existem talvez coisas que eu não lhe disse aqui, por exemplo o meu apelido, o apelido que o meu mestre me atribuiu, ele me chamava de Ngumbá, e na língua daqui isso quer dizer porco-espinho, talvez Kibandí também tivesse se acostumado à ideia de que eu não passava de um porco-espinho, um porco-espinho ordinário, é evidente, ele era um humano, e como eu não gostava desse apelido com sonoridades desagradáveis, fingia não ter escutado quando ele me chamava assim, mas ele insistia, você entende agora porque desde o começo eu não quis que você soubesse desse nome

agora há pouco, ao me espreguiçar, descobri provisões atrás do seu pé, isso me parece ainda assim estranho, me pergunto se não tem um outro ocupante aqui, entretanto não vi passar nenhum outro animal desde ontem, e, pela lógica, essas provisões me pertencem doravante, não ouse crer que elas tenham sido depositadas aqui pelo outro ele mesmo do meu mestre, eu o teria escutado chegar como na época em que ele se manifestava, ele também desapareceu no dia em que esses pequenos monstros, esses meninos o agitavam como uma marionete

só me arrependo de uma coisa, é de não escutar a sua voz, meu querido Baobá, e se você pudesse falar como eu, me sentiria bem menos sozinho, mas o que conta a essa altura é a sua presença, ela me deixa menos angustiado, e se eu vir daqui o perigo chegando, acredite em mim, eu só terei que deslizar para um dos seus buracos, você não poderá jamais me entregar às mãos da morte, não é mesmo, peço desculpas de antemão por fazer as minhas necessidades aqui, ainda tenho medo de me afastar, de cometer uma besteira, de sentir falta da sua proteção, ignoro quanto tempo durará esse estado de alerta, eu sei que você não aprecia que eu defeque no seu pé, ora os homens dizem que são os excrementos que fazem crescer os vegetais, então, de alguma maneira, eu contribuo também para a sua longevidade, é tudo o que posso lhe oferecer em troca da sua hospitalidade

na verdade, eu me forcei bastante, não tenho apetite, no entanto é preciso comer, todas essas nozes de palma não têm mais o gosto de antes, eu ainda as amadureço, estudo, farejo, tento empurrar algumas goela abaixo, elas são amargas, não tenho força para mastigar, eu sei que isso só revela o pânico e a apreensão que me marcaram nesses últimos tempos, devo agora relaxar, me distender, não comemos quando o coração bate muito rápido, tenho a impressão de que quero de comer para me tranquilizar, e talvez para não morrer de fome, e desde a sexta-feira passada acho que perdi peso, tenho a língua pastosa, o rabo baixo, os olhos vermelhos, os quatro membros lânguidos, e quando eu tusso, porque eu tusso mesmo muito nessas últimas horas, tenho a impressão de vomitar os meus pulmões, posso ficar ainda muito tempo sem comer, não estou nem aí já que não sinto nenhum buraco no estômago, e se é preciso morrer, que essa morte venha ao menos pela fome 
nessa segunda-feira ensolarada, tenho vontade de tomar resoluções a longo termo, de ver o futuro com otimismo, de tirar sarro do amanhã, escuto uma voz interior que me sopra que não vou morrer hoje, menos ainda amanhã, nem depois de amanhã, deve haver uma explicação para isso, não sou eu quem vai procurá-la, aquele que criou o universo sem dúvida compreendeu que eu fui apenas vítima dos modos das pessoas desse país, a minha sobrevivência seria então um desaforo àqueles que gostariam de no futuro transmitir um duplo nocivo a seus filhos, quanto tempo deveria eu viver agora, hein, não sei de nada, meu querido Baobá, " a cada dia basta sua pena", teria dito nosso velho governante que, sem aparentar, terá influenciado a minha conduta, no fundo o admiro, tem vezes que penso que esse velho amuado me faz falta, teria gostado de escutá-lo ainda falando conosco, nos dando uma das suas lições mais brilhantes como nesse dia em que ele nos falava da matéria, desses três estados mais correntes e suas mudanças, ele falava então do estado líquido, do estado gasoso, do estado sólido, percebia bem que nós continuávamos duvidando e queríamos exemplos concretos, e nos detalhava à sua maneira a fusão, a sublimação, a solidificação, a liquefação ou a vaporização, pobre velho, era um porco-espinho digno desse nome, deve estar morto há anos, assim como os companheiros da minha geração, certamente

não pedi para sobreviver, como aliás não pedirei para morrer, me contento em respirar, em ver o que poderia fazer de útil no futuro, tenho para isso dois caminhos que gostaria de seguir, primeiro gostaria de travar uma batalha sem trégua contra os duplos nocivos desta região, sei que é um grande combate, mas gostaria de persegui-los uns após os outros, uma maneira de me redimir, de apagar a minha parte de responsabilidade quanto às desgraças que entristeceram este vilarejo e vários outros, o segundo caminho com o qual eu sonho é simples, meu querido Baobá, gostaria de voltar a viver em nosso antigo território porque a frequentação dos homens criou em mim o sentimento de nostalgia, um sentimento que eu qualificaria de mal do território, eles falariam em mal do país, me agarro doravante às minhas lembranças como o elefante se agarra aos seus dentes, são essas imagens longínquas, essas sombras desaparecidas, esses barulhos afastados que me impedem de cometer o irreparável, sim, o irreparável, penso nisso também, me dar a morte, mas é a pior das covardias, assim como os seres humanos estimam que a sua existência vem de um ser supremo, acabei eu mesmo acreditando nisso desde a sexta-feira passada, e se eu ainda existo, palavra de porco-espinho, é porque uma vontade acima de mim decidiu isso, ora se isso foi decidido assim, é porque devo certamente ter uma última missão para realizar aqui 
tenho outros projetos em mente, meu querido Baobá, gostaria por exemplo de encontrar uma boa fêmea, não apenas para um simples ato de copulação com o objetivo de procriar como os outros animais, mas pelo prazer primeiro, o prazer da minha parceira e o meu, depois, é claro, para fazer os pequenos com ela se nós encontrarmos afinidades, e então, tornado pai, contarei à minha descendência a vida e os modos dos homens, prevenirei essa descendência de todo destino que se parecer ao meu, e, meu querido Baobá, você deve me achar irrazoável, ambicioso, sobretudo irrealista quando pensa que tenho 42 anos hoje, e depois, palavra de porco-espinho, a idade não me dá medo, li no grosso livro de Deus que antigamente os humanos viviam durante séculos e séculos inteiros, o patriarca deles que chamavam de Matusalém viveu mesmo 969 anos, vou lhe dizer que não sou um porco-espinho acabado, gostaria de ser o Matusalém da espécie animal, ainda tenho resistência, agilidade, o negócio é que eu possa consagrar o tempo que me resta fazendo o bem, apenas o bem, me transformar talvez em duplo pacífico

sim eu ainda tenho resistência, e estou certo de que os meus poderes estão intactos, ah, vejo que você remexe seus galhos em sinal de incredulidade, você não acredita que me reste um poder qualquer, hein, você quer a todo preço ter a prova disso aqui e agora, pois bem vamos lá, me deixe levantar, encolher, concentrar, e pá, e pá, e pá de novo, palavra de porco-espinho, você viu como eu acabei de projetar três dos meus espinhos, hein, além do mais eles foram cair a várias centenas de metros daqui, ainda mais longe do que quando eu estava a serviço do meu mestre, de que outra prova você precisa para compreender que ainda vão ouvir falar de mim, hein 
Anexo

\title{
Carta do Escargô cabeçudo sobre a origem do manuscrito Memórias de porco-espinho
}

\author{
Senhor Escargô cabeçudo \\ Executor testamentário literário de Copo Quebrado \\ Dono do bar O Crédito viajou
}

Às Editions du Seuil

25 , rua Jacob

75006 Paris - França

Assunto: Envio do manuscrito Memórias de porco-espinho, texto póstumo do meu amigo Copo Quebrado

Senhora, Senhor,

Vos escrevo como executor testamentário literário do meu amigo de sempre, o defunto Copo Quebrado. Gostaria que esta carta fosse publicada ao final do livro Memórias de porcoespinho a fim de levar um pouco mais de precisão aos leitores quanto à origem desse texto.

$E$ Everdade que no ano passado, logo após sua morte, eu lhes fiz chegar por carta registrada o que eu acreditava ser então seu único manuscrito, já que era eu quem o havia encomendado em vista de imortalizar meu bar O Crédito viajou. Esse primeiro texto, os senhores o haviam publicado alguns meses depois sob o título Copo Quebrado mesmo quando eu pedi formalmente que o romance se intitulasse O Crédito viajou. Os senhores haviam decidido - parece que em nome do livro - não levar isso em conta...

De qualquer maneira, não lhes escrevo para alimentar uma polêmica sobre esse assunto. Tenho ao contrário o imenso prazer de lhes enviar este outro manuscrito que um dos meus empregados, o garçom Momperô, encontrou em um bosque, perto do rio Tchinuká onde foi resgatado o corpo do saudoso Copo Quebrado. O documento original - uma velha pasta escolar com folhas soltas - estava em um estado tão lamentável que nos foi preciso muita precaução para juntar as páginas, ordená-las antes de numerá-las. Para isso, quando não havia muitos clientes no bar, nós nos juntávamos os três, meus empregados e eu, ao redor da mesa que ocupava normalmente o defunto Copo Quebrado. Nós decifrávamos então as passagens apagadas pela sujeira, chuva e orvalho. Confrontávamos a cada vez nossos pontos de vista a fim de não ceder à tentação de atribuir ao defunto o que ele não havia escrito. Nossas trocas, admito, eram mais que virulentas, inflamadas, e isso exasperava alguns dos meus clientes. Alguns dentre eles, como $\mathrm{O}$ tipo de Pampers $e$ Robinette, negam sempre certas cenas que lhes foram atribuídas no romance Copo Quebrado. Por isso, eles encararam muito mal o anúncio da descoberta de um segundo caderno, acreditando erroneamente que Memórias de porco-espinho fosse apenas a sequência de Copo Quebrado! Na verdade eles temiam ser uma vez mais devorados por aquele que eles continuam qualificando de traidor da última categoria que lhes terá roubado histórias de vida antes de ir juntar-se a sua mãe nas águas cinzentas do Tchinuká... 


\section{Mas voltemos a este novo manuscrito!}

Uma vez o duro trabalho de reconstituição terminado, confiei pessoalmente a datilografia de Memórias de porco-espinho a uma estudante do colégio técnico KenguêPauline. Ela me cobrou, vejam bem, 2000 francos CFA por página, quer dizer o preço de uma boa garrafa de vinho tinto no meu bar! Para justificar essa tarifa elevada do calhamaço datilografado, ela sustentava que a escritura do defunto Copo Quebrado era indecifrável, e a pobre moça tinha de às vezes reler duas ou três vezes a mesma linha, tudo isso por causa dessa obstinação do autor de empregar a vírgula como único sinal de pontuação.

Foram então essas desventuras que me impediram, Cara Senhora, Caro Senhor, de lhes endereçar este manuscrito mais cedo, e estou enfim aliviado de lhes submetê-lo acompanhado do documento original a fim de que os senhores possam, em caso de dificuldade, verificar algumas das nossas reconstituições, sobretudo nas duas últimas partes intituladas respectivamente "como a sexta-feira passada se tornou uma sexta-feira de tristeza" e "como ainda não sou um porco-espinho acabado". Essas partes eram as mais prejudicadas do documento...

Nesse texto Copo Quebrado se apaga e não é mais um narrador onipresente, menos ainda um personagem da história. No fundo, ele estava persuadido de que os livros que nos acompanham por um tempo longo são aqueles que reinventam o mundo, revisitam nossa infância, interrogam a Origem, examinam nossas obsessões e sacodem nossas crenças. Desse modo, nos oferecendo esta última crônica que ele intitulou Memórias de porco-espinho - e eu espero de todo coração que os senhores não mudem dessa vez o título do livro -, Copo Quebrado traça então de modo alegórico suas últimas vontades. Para ele, o mundo é apenas uma versão aproximada de uma fábula que nós não compreenderemos jamais enquanto continuarmos considerando apenas a representação material das coisas.

Não posso me conter de lhes confiar que me deixei levar pelo destino desse estranho porco-espinho ao mesmo tempo cativante, falante, agitado, muito familiar à natureza humana e usando a digressão como arma até o fim com o intuito de nos pintar, nós humanos, e por vezes nos culpar sem trégua. E desde então, não vejo mais os animais com os mesmos olhos. Além do mais, quem entre o Homem e o animal é verdadeiramente uma besta? Vasta questão!

Alegrando-me com nossa nova colaboração, peço-vos que aceitem, Senhora, Senhor, meus sentimentos mais cordiais.

Escargô cabeçudo

Executor testamentário literário de Copo Quebrado

Dono do bar O Crédito viajou 